\title{
Thermal rearrangement of 4-aryl-4-hydroxy-2-cyclobuten-1-ones and application of the methodology in the formation of benzofuronaphthoquinones and benzocarbazolequinones
}

\author{
Kimberly Denise Fisher \\ West Virginia University
}

Follow this and additional works at: https://researchrepository.wvu.edu/etd

\section{Recommended Citation}

Fisher, Kimberly Denise, "Thermal rearrangement of 4-aryl-4-hydroxy-2-cyclobuten-1-ones and application of the methodology in the formation of benzofuronaphthoquinones and benzocarbazolequinones" (2008). Graduate Theses, Dissertations, and Problem Reports. 4372.

https://researchrepository.wvu.edu/etd/4372

This Dissertation is protected by copyright and/or related rights. It has been brought to you by the The Research Repository @ WVU with permission from the rights-holder(s). You are free to use this Dissertation in any way that is permitted by the copyright and related rights legislation that applies to your use. For other uses you must obtain permission from the rights-holder(s) directly, unless additional rights are indicated by a Creative Commons license in the record and/ or on the work itself. This Dissertation has been accepted for inclusion in WVU Graduate Theses, Dissertations, and Problem Reports collection by an authorized administrator of The Research Repository @ WVU.

For more information, please contact researchrepository@mail.wvu.edu. 


\title{
Thermal Rearrangement of 4-Aryl-4-Hydroxy-2- Cyclobuten-1-ones and Application of the Methodology in the Formation of Benzofuronaphthoquinones and Benzocarbazolequinones
}

\author{
Kimberly Denise Fisher
}

\author{
Dissertation submitted to the \\ Eberly College of Arts and Sciences \\ at West Virginia University \\ in partial fulfillment of the requirements \\ for the degree of \\ Doctor of Philosophy \\ in \\ Chemistry \\ Dr. Björn C. G. Söderberg, Chair \\ Dr. Robert. K. Griffith \\ Dr. John H. Penn \\ Dr. Alan M.Stolzenberg \\ Dr. Kung K. Wang
}

C. Eugene Bennett Department of Chemistry

Morgantown, West Virginia

2008 


\title{
ABSTRACT
}

\section{Thermal Rearrangement of 4-Aryl-4-Hydroxy-2- Cyclobuten-1-ones and Application of the Methodology in the Formation of Benzofuronaphthoquinones and Benzocarbazolequinones}

\author{
Kimberly Denise Fisher
}

Cyclobutenediones have proven useful as starting materials for synthesis of highly functionalized biologically relevant molecules. The rearrangement of cyclobutendiones has a wide synthetic scope and can be utilized as a key step in the construction of quinones, benzo[o]isoxazoles, and 3-methylenoxoindoles having a variety of substitution patterns. Construction of these molecules involves thermolysis of 4-hydroxy-2,4-di-aryl-2-cyclobutenones derived from squaric acid ester. In each of the cases the mechanism proceeds through an initial ring opening of the cyclobutene to afford a ketene intermediate that subsequently undergoes a ring closure with various intermolecular nucleophiles. This methodology has been utilized in the construction of an ellipticine model system. 


\section{Acknowledgements}

I would like to thank my research advisor, Dr. Björn C. G. Söderberg, for guidance and support through my graduate career at West Virginia University. There are many qualities you hold that I hope to possess in my future as a Professor. I would also like to thank the members of my graduate committee, Dr. Robert Griffth, Dr. John Penn, Dr. Jeffery Petersen, Dr. Alan Stolzenberg, and Dr. Kung Wang, for their time and assistance during my graduate studies.

I would like to thank Dr. Novrus Akhmedov for advanced NMR studies and Dr. Jeffrey Petersen for X-ray Crystallographic analysis included in this document.

I would also like to thank my colleagues and friends in the chemistry department whose presence in my life will go far beyond the limits of the time at WVU.

I would also like to thank: Albert "JR" Taylor, Allan Burns, Sherman Adams, Phillip Tucker, Don Feathers, Kevin Dixon, Ezenwa Dike, Mike Torries, Angie Johnson, Ginny Smith, Bob Smith, Brent Reschke, Dottie McCabe, Marianne MacDonald, Ken Enoch, Dr. Harry Finklea, Dr. Michelle Richards-Babb, Dr. George O’Doherty, Dr. Fred King, and Dr. Lisa Holland all of whom had a irreplaceable impact on my success at WVU.

I especially want to thank Mr. Sriganesh Balasubramanian for his constant help and understanding throughout the past months. I am indebted to you for the rest of my life. Thanks Sri!!

I would also like to thank my family for their constant love and support throughout this long road. Without you, there is no me. I love you. 


\section{Table of Contents}

$\begin{array}{ll}\text { Title Page } & \text { i }\end{array}$

$\begin{array}{ll}\text { Abstract } & \text { ii }\end{array}$

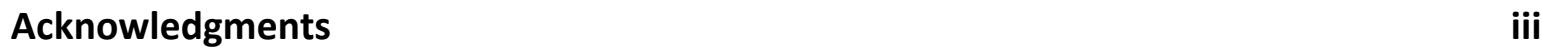

Table of Contents $\quad$ iv

List of Figures $\quad v$

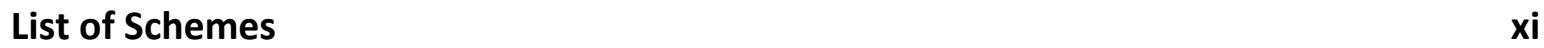

List of Tables $\quad$ xiv

List of Commonly Used Acronyms $\quad$ XV

$\begin{array}{ll}\text { Part 1: Introduction } & 1\end{array}$

$\begin{array}{ll}\text { Part 2: Results and Discussion } & 19\end{array}$

$\begin{array}{lr}\text { Chapter } 1 & 19\end{array}$

$\begin{array}{ll}\text { Chapter } 2 & 33\end{array}$

$\begin{array}{ll}\text { Chapter } 3 & 46\end{array}$

$\begin{array}{ll}\text { Part 3: Experimental Section } & 57\end{array}$

General Procedures $\quad 57$

Experimental Details $\quad 58$

$\begin{array}{ll}\text { References } & 95\end{array}$

$\begin{array}{lr}\text { Appendix } & 98\end{array}$ 


\section{List of Figures}

Figure 1 X-Ray Crystal Structure of 37

Figure $2{ }^{1} \mathrm{H}$ NMR tert-Butyl 2-(1-hydroxy-2,3-diisopropoxy-4-oxocyclobut-2-

enyl)phenylcarbamate (5)

Figure $3{ }^{13} \mathrm{C}$ NMR tert-Butyl 2-(1-hydroxy-2,3-diisopropoxy-4-oxocyclobut-2-

enyl)phenylcarbamate (5)

100

Figure $4{ }^{1} \mathrm{H}$ NMR tert-Butyl 1,4-dihydro-2,3-diisopropoxy-1,4-dioxonaphthalen-5-ylcarbamate (6)

101

Figure $5{ }^{13} \mathrm{C}$ NMR tert-Butyl 1,4-dihydro-2,3-diisopropoxy-1,4-dioxonaphthalen-5-ylcarbamate (6)

Figure $6{ }^{1} \mathrm{H}$ NMR tert-Butyl 2-(1-hydroxy-2,3-diisopropoxy-4-oxocyclobut-2-enyl)-6methoxyphenylcarbamate (10)

Figure $7{ }^{13} \mathrm{C}$ NMR tert-Butyl 2-(1-hydroxy-2,3-diisopropoxy-4-oxocyclobut-2-enyl)-6methoxyphenylcarbamate (10)

Figure $8{ }^{1} \mathrm{H}$ NMR tert-Butyl 3-(1-hydroxy-2,3-diisopropoxy-4-oxocyclobut-2-enyl)-2methoxyphenylcarbamate(11)

Figure $9{ }^{13} \mathrm{C}$ NMR tert-Butyl 3-(1-hydroxy-2,3-diisopropoxy-4-oxocyclobut-2-enyl)-2methoxyphenylcarbamate(11)

Figure $10{ }^{1} \mathrm{H}$ NMR tert-Butyl 2-(1-hydroxy-2,3-diisopropoxy-4-oxocyclobut-2-enyl)-5methoxyphenylcarbamate (12)

Figure $11{ }^{1} \mathrm{H}$ NMR tert-Butyl 2-(1-hydroxy-2,3-diisopropoxy-4-oxocyclobut-2-enyl)-3methoxyphenylcarbamate (14)

Figure $12{ }^{1} \mathrm{H}$ NMR tert-Butyl 2-(1-hydroxy-2,3-diisopropoxy-4-oxocyclobut-2-enyl)-4methoxyphenylcarbamate (15)

Figure $13{ }^{1} \mathrm{H}$ NMR tert-Butyl 3-(1-hydroxy-2,3-diisopropoxy-4-oxocyclobut-2-enyl)-4methoxyphenylcarbamate (16)

Figure $14{ }^{1} \mathrm{H}$ NMR tert-Butyl 1,4-dihydro-2,3-diisopropoxy-5-methoxy-1,4-dioxonaphthalen-6ylcarbamate (18) 
Figure $15{ }^{1} \mathrm{H}$ NMR tert-Butyl 1,4-dihydro-2,3-diisopropoxy-6-methoxy-1,4-dioxonaphthalen-8ylcarbamate (19)

Figure $16{ }^{1} \mathrm{H}$ NMR tert-Butyl 1,4-dihydro-2,3-diisopropoxy-5-methoxy-1,4-dioxonaphthalen-8ylcarbamate (20)

Figure $17{ }^{13} \mathrm{C}$ NMR tert-Butyl 1,4-dihydro-2,3-diisopropoxy-5-methoxy-1,4-dioxonaphthalen8-ylcarbamate (20)

Figure $18{ }^{1} \mathrm{H}$ NMR tert-Butyl 5,8-dihydro-6,7-diisopropoxy-5,8-dioxoquinolin-4-ylcarbamate

Figure $19{ }^{13} \mathrm{C}$ NMR tert-Butyl 5,8-dihydro-6,7-diisopropoxy-5,8-dioxoquinolin-4-ylcarbamate

Figure $20{ }^{1} \mathrm{H}$ NMR N-(2-(1-hydroxy-2,3-diisopropoxy-4-oxocyclobut-2-enyl)phenyl)pivalamide

Figure $21{ }^{13}$ C NMR N-(2-(1-hydroxy-2,3-diisopropoxy-4-oxocyclobut-2-enyl)phenyl)pivalamide

Figure $22{ }^{1} \mathrm{H}$ NMR N-(1,4-dihydro-2,3-diisopropoxy-1,4-dioxonaphthalen-5-yl)pivalamide (37)

Figure $23{ }^{1} \mathrm{H}$ NMR N-(1,4-dihydro-2-hydroxy-3-isopropoxy-1,4-dioxonaphthalen-5yl)pivalamide (38)

Figure $24{ }^{13} \mathrm{C}$ NMR N-(1,4-dihydro-2-hydroxy-3-isopropoxy-1,4-dioxonaphthalen-5yl)pivalamide (38)

Figure $25{ }^{1} \mathrm{H}$ NMR 4-hydroxy-2,3-diisopropoxy-4-(2-nitrophenyl)cyclobut-2-enone (39) 122

Figure $26{ }^{13} \mathrm{C}$ NMR 4-hydroxy-2,3-diisopropoxy-4-(2-nitrophenyl)cyclobut-2-enone (39) 123

Figure $27{ }^{1}$ H NMR ,3-diisopropyl-1-hydroxy-4(1H)-quinolinone (40)

Figure $28{ }^{13} \mathrm{C}$ NMR ,3-diisopropyl-1-hydroxy-4(1H)-quinolinone (40)

Figure $29{ }^{1} \mathrm{H}$ NMR 4-(2-bromophenyl)-4-hydroxy-2,3-diisopropoxycyclobut-2-enone (49) 126

Figure $30{ }^{13} \mathrm{C}$ NMR 4-(2-bromophenyl)-4-hydroxy-2,3-diisopropoxycyclobut-2-enone (49) 127

Figure $31{ }^{1} \mathrm{H}$ NMR 5-bromo-2,3-diisopropoxynaphthalene-1,4-dione (50)

Figure $32{ }^{13} \mathrm{C}$ NMR 5-bromo-2,3-diisopropoxynaphthalene-1,4-dione (50) 
Figure $33{ }^{1}$ H NMR tert-Butyl 2-(2-isopropoxy-3,4-dioxocyclobut-1-enyl)phenylcarbamate (61)

Figure $34{ }^{13} \mathrm{C}$ NMR tert-Butyl 2-(2-isopropoxy-3,4-dioxocyclobut-1-enyl)phenylcarbamate (61)

Figure 35 HETCOR tert-Butyl 2-(2-isopropoxy-3,4-dioxocyclobut-1-enyl)phenylcarbamate (61)

Figure $36{ }^{1} \mathrm{H}$ NMR N-(2-(2-isopropoxy-3,4-dioxocyclobut-1-enyl)phenyl)pivalamide (62) 133

Figure $37{ }^{13} \mathrm{C}$ NMR N-(2-(2-isopropoxy-3,4-dioxocyclobut-1-enyl)phenyl)pivalamide (62) 134

Figure $38{ }^{1} \mathrm{H}$ NMR tert-Butyl 2-(3-hydroxy-2-isopropoxy-4-oxo-3-phenylcyclobut-1-

enyl)phenylcarbamate (63)

Figure $39{ }^{13} \mathrm{C}$ NMR tert-Butyl 2-(3-hydroxy-2-isopropoxy-4-oxo-3-phenylcyclobut-1-

enyl)phenylcarbamate (63)

Figure $40{ }^{1} \mathrm{H}$ NMR N-(2-(3-hydroxy-2-isopropoxy-4-oxo-3-phenylcyclobut-1-

enyl)phenyl)pivalamide (64)

Figure $41{ }^{13}$ C NMR N-(2-(3-hydroxy-2-isopropoxy-4-oxo-3-phenylcyclobut-1-

enyl)phenyl)pivalamide (64)

Figure $42{ }^{1} \mathrm{H}$ NMR N-(2-(3-Trimethylsilylhydroxy-2-isopropoxy-4-oxo-3-phenylcyclobut-1-

enyl)phenyl)pivalamide (65)

Figure $43{ }^{1} \mathrm{H}$ NMR tert-Butyl 2-(3-Trimethylsilylhydroxy-2-isopropoxy-4-oxo-3-phenylcyclobut1-enyl)phenylcarbamate (66)

Figure $44{ }^{13} \mathrm{C}$ NMR tert-Butyl 2-(3-Trimethylsilylhydroxy-2-isopropoxy-4-oxo-3-

phenylcyclobut-1-enyl)phenylcarbamate (66)

Figure $45{ }^{1} \mathrm{H}$ NMR 3-(2-trimethylsilylhydroxy-1-isopropoxy-2-phenylethylidene)-1-

(pivaloyl)indolin-2-one (67)

Figure $46{ }^{13} \mathrm{C}$ NMR 3-(2-trimethylsilylhydroxy-1-isopropoxy-2-phenylethylidene)-1-

(pivaloyl)indolin-2-one (67)

Figure $47{ }^{1} \mathrm{H}$ NMR tert-Butyl 3-(2-Trimethylsilylhydroxy-1-isopropoxy-2-phenylethylidene)-2-

oxoindoline-1-carboxylate (68)

144 
Figure $48{ }^{13} \mathrm{C}$ NMR tert-Butyl 3-(2-Trimethylsilylhydroxy-1-isopropoxy-2-phenylethylidene)-2oxoindoline-1-carboxylate (68)

Figure 49 HETCOR tert-Butyl 3-(2-Trimethylsilylhydroxy-1-isopropoxy-2-phenylethylidene)-2oxoindoline-1-carboxylate (68)

Figure $50{ }^{1} \mathrm{H}$ NMR 3-(2-phenyl-ethan-2-one)-1-(pivaloyl)indolin-2-one (74)

Figure $51{ }^{13} \mathrm{C}$ NMR 3-(2-phenyl-ethan-2-one)-1-(pivaloyl)indolin-2-one (74) 148

Figure $52{ }^{1}$ H NMR 3-(2-phenyl-ethan-2-one)-indolin-2-one (75) 149

Figure $53{ }^{13} \mathrm{C}$ NMR 3-(2-phenyl-ethan-2-one)-indolin-2-one (75) 150

Figure $54{ }^{1} \mathrm{H}$ NMR 3-(1-isopropoxy-2-oxo-2-phenylethylidene)-1-(pivaloyl)indolin-2-one (76)

Figure $55{ }^{13} \mathrm{C}$ NMR 3-(1-isopropoxy-2-oxo-2-phenylethylidene)-1-(pivaloyl)indolin-2-one (76)

Figure $56{ }^{1} \mathrm{H}$ NMR N-(2-(3-hydroxy-2-isopropoxy-3-(4-methoxyphenyl)-4-oxocyclobut-1enyl)phenyl)pivalamide (77)

Figure $57{ }^{13} \mathrm{C}$ NMR N-(2-(3-hydroxy-2-isopropoxy-3-(4-methoxyphenyl)-4-oxocyclobut-1enyl)phenyl)pivalamide (77)

Figure $58{ }^{1} \mathrm{H}$ NMR 3-(1-isopropoxy-2-(4-methoxyphenyl)-2-oxoethylidene)indolin-2-one (78)

Figure $59{ }^{13} \mathrm{C}$ NMR 3-(1-isopropoxy-2-(4-methoxyphenyl)-2-oxoethylidene)indolin-2-one (78)

Figure $60{ }^{1} \mathrm{H}$ NMR 3-isopropoxy-4-(2-nitrophenyl)cyclobut-3-ene-1,2-dione (81)

Figure $61{ }^{13} \mathrm{C}$ NMR 3-isopropoxy-4-(2-nitrophenyl)cyclobut-3-ene-1,2-dione (81)

Figure $62{ }^{1} \mathrm{H}$ NMR 4-hydroxy-3-isopropoxy-2-(2-nitrophenyl)-4-phenylcyclobut-2-enone (82)

Figure $63{ }^{1}$ H NMR 2-(benzo[c] isoxazol-3-yl)-2-isopropoxy-1-phenylvinyl acetate (85) 160

Figure $64{ }^{13} \mathrm{C}$ NMR 2-(benzo[c]isoxazol-3-yl)-2-isopropoxy-1-phenylvinyl acetate (85) 161 
Figure $65{ }^{1}$ H NMR 3-(2-hydroxyphenyl)-4-isopropoxycyclobut-3-ene-1,2-dione (93)

Figure $66{ }^{13} \mathrm{C}$ NMR 3-(2-hydroxyphenyl)-4-isopropoxycyclobut-3-ene-1,2-dione (93)

163

Figure $67{ }^{1} \mathrm{H}$ NMR 4-hydroxy-2,3-diisopropoxy-4-(2-methoxyphenyl)cyclobut-2-enone (94)

Figure $68{ }^{13} \mathrm{C}$ NMR 4-hydroxy-2,3-diisopropoxy-4-(2-methoxyphenyl)cyclobut-2-enone (94)

Figure $69{ }^{1} \mathrm{H}$ NMR 3-isopropoxy-4-(2-methoxyphenyl)cyclobut-3-ene-1,2-dione (96) 166

Figure $70{ }^{13} \mathrm{C}$ NMR 3-isopropoxy-4-(2-methoxyphenyl)cyclobut-3-ene-1,2-dione (96) 167

Figure $71{ }^{1} \mathrm{H}$ NMR 4-hydroxy-2-(2-hydroxyphenyl)-3-isopropoxy-4-phenylcyclobut-2-enone

168

Figure $72{ }^{13} \mathrm{C}$ NMR 4-hydroxy-2-(2-hydroxyphenyl)-3-isopropoxy-4-phenylcyclobut-2-enone (97)

Figure $73{ }^{1} \mathrm{H}$ NMR 4-hydroxy-3-isopropoxy-2-(2-methoxyphenyl)-4-phenylcyclobut-2-enone (99)

170

Figure $74{ }^{13} \mathrm{C}$ NMR 4-hydroxy-3-isopropoxy-2-(2-methoxyphenyl)-4-phenylcyclobut-2-enone (99)

Figure $75{ }^{1} \mathrm{H}$ NMR 2-isopropoxy-3-(2-methoxyphenyl)naphthalene-1,4-dione (100) 172

Figure $76{ }^{13} \mathrm{C}$ NMR 2-isopropoxy-3-(2-methoxyphenyl)naphthalene-1,4-dione (100) 173

Figure $77{ }^{1} \mathrm{H}$ NMR 3-(2-bromophenyl)-4-isopropoxycyclobut-3-ene-1,2-dione (104) 174

Figure $78{ }^{13} \mathrm{C}$ NMR 3-(2-bromophenyl)-4-isopropoxycyclobut-3-ene-1,2-dione (104) 175

Figure $79{ }^{1} \mathrm{H}$ NMR 2-(2-bromophenyl)-4-hydroxy-3-isopropoxy-4-phenylcyclobut-2-enone

Figure $80{ }^{1} \mathrm{H}$ NMR 2-(2-bromophenyl)-3-isopropoxynaphthalene-1,4-dione (106)

Figure $81{ }^{13} \mathrm{C}$ NMR 2-(2-bromophenyl)-3-isopropoxynaphthalene-1,4-dione (106)

Figure $82{ }^{1} \mathrm{H}$ NMR 2-amino-3-(2-bromophenyl)naphthalene-1,4-dione (109)

Figure $83{ }^{13} \mathrm{C}$ NMR 2-amino-3-(2-bromophenyl)naphthalene-1,4-dione (109) 
Figure $84{ }^{1} \mathrm{H}$ NMR 5H-benzo[b]carbazole-6,11-dione (110)

Figure $85{ }^{13} \mathrm{C}$ NMR 5H-benzo[b]carbazole-6,11-dione (110)

Figure $86{ }^{1}$ H NMR 2-(2-bromophenyl)-4-hydroxy-3-isopropoxy-4-(4-methoxyphenyl)cyclobut2-enone (111) 183

Figure $87{ }^{13} \mathrm{C}$ NMR 2-(2-bromophenyl)-4-hydroxy-3-isopropoxy-4-(4-methoxyphenyl)cyclobut2-enone (111) 184

Figure $88{ }^{1}$ H NMR 3-(2-bromophenyl)-2-isopropoxy-6-methoxynaphthalene-1,4-dione (112)

Figure $89{ }^{13} \mathrm{C}$ NMR 3-(2-bromophenyl)-2-isopropoxy-6-methoxynaphthalene-1,4-dione (112)

Figure $90{ }^{1} \mathrm{H}$ NMR 2-amino-3-(2-bromophenyl)-6-methoxynaphthalene-1,4-dione (113) 187 Figure $91{ }^{13} \mathrm{C}$ NMR 2-amino-3-(2-bromophenyl)-6-methoxynaphthalene-1,4-dione (113) 188 Figure $92{ }^{1} \mathrm{H}$ NMR 9-methoxy-5H-benzo[b]carbazole-6,11-dione (114) 189

Figure $93{ }^{13} \mathrm{C}$ NMR 9-methoxy-5H-benzo[b]carbazole-6,11-dione (114) 190

Figure $94{ }^{1}$ H NMR 2-(2-bromophenyl)-4-hydroxy-3-isopropoxy-4-(2-methoxyphenyl)cyclobut2-enone (115) 191

Figure $95{ }^{13}$ C NMR 2-(2-bromophenyl)-4-hydroxy-3-isopropoxy-4-(2-methoxyphenyl)cyclobut2-enone (115) 192

Figure $96{ }^{1} \mathrm{H}$ NMR 2-(2-bromophenyl)-3-isopropoxy-5-methoxynaphthalene-1,4-dione (116) 193

Figure $97{ }^{13} \mathrm{C}$ NMR 2-(2-bromophenyl)-3-isopropoxy-5-methoxynaphthalene-1,4-dione (116) 194

Figure $98{ }^{1} \mathrm{H}$ NMR 3-amino-2-(2-bromophenyl)-5-methoxynaphthalene-1,4-dione (117) 195 Figure $99{ }^{13} \mathrm{C}$ NMR 3-amino-2-(2-bromophenyl)-5-methoxynaphthalene-1,4-dione (117) 196 Figure $100{ }^{1} \mathrm{H}$ NMR 7-methoxy-5H-benzo[b]carbazole-6,11-dione (118) 197

Figure $101{ }^{13} \mathrm{C}$ NMR 7-methoxy-5H-benzo[b]carbazole-6,11-dione (118) 198 
Figure $102{ }^{1} \mathrm{H}$ NMR 2-(2-bromophenyl)-3-hydroxynaphthalene-1,4-dione (119)

Figure $103{ }^{13} \mathrm{C}$ NMR 2-(2-bromophenyl)-3-hydroxynaphthalene-1,4-dione (119)

List of Schemes

Scheme 1 Quinones and Naphthoquinones

Scheme 2 Notable Naphthoquinones

Scheme 3 Naphthoquinone Redox Forms

Scheme 4 Variety of Naphthoquinones Syntheses

Scheme 5 Dötz Methodology

Scheme 6 Dötz Protocol in the Shikonin and Calceolaria Andina L Syntheses

Scheme 7 Hauser-Kraus Annulation Reaction

Scheme 8 Hauser-Kraus Annulation in the Synthesis of Alkannin and Shikonin

Scheme 9 [4+2] Cycloaddition Reaction Method

Scheme 10 Quinone Diene Method

Scheme 11 Benzyne Dienophile Method

Scheme 12 Synthesis of Crisamicin A.

Scheme 13 Stobbe Condesation

Scheme 14 Synthesis of Ventiloquinone and Isoventiloquinone

Scheme 15 General Thermal Rearrangements of 4 hydroxycyclobutendiones.

Scheme 16 Strategies of Forming Naphthoquinones from Cyclobutendiones

Scheme 17 General Aryl Addition-Rearrangement

Scheme 18 Alkene Rearrangement Mechanism

Scheme 19 Alkyne Rearrangement Mechanism 
Scheme 20 Deoxyfrenolicin Synthesis

Scheme 21 Benzometallocycle Methodology

Scheme 22 Nanaomycin A Synthesis

Scheme 23 Proposed Synthesis of Aminonaphthoquinones

Scheme 24 Carbamate Protected Aniline Addition-Thermolysis

Scheme 25 Aminoanisidine Carbamate Protection

Scheme 26 Carbamate Aminopyridine Protection

Scheme 27 Pivaloyl-Protected Aniline Addition Thermolysis

Scheme 28 Nitrobenzene Halogen Exchange Protocol

Scheme 29 Nitronbenzene Addition-Thermolysis

Scheme 30 Nitrobenzene Proposed Mechanism

Scheme 31 BromoBenzene Addition-Thermolysis Method

Scheme 32 Moore TFAA Rearrangement

Scheme 33 Liebeskind Aryl Addition-Thermolysis Protocol

Scheme 34 Ellipticine Model System

Scheme 35 Thermal Rearrangment of 63 and 64

Scheme 36 Synthesis of 65 and 66

Scheme 37 Synthesis of 67 and 68

Scheme 38 Proposed Mechanism of 67 and 68

Scheme 39 Reinvestigation of Thermal Rearrangement of 64 Products

Scheme $\mathbf{4 0}$ Synthesis of 78

Scheme 41 Revised Methodology to 58 
Scheme 42 Synthesis of 81

Scheme 43 Thermal Rearrangement of 82

Scheme 44 Thermal Rearrangement of 84

Scheme 45 Proposed Mechanism to 50

Scheme 46 Methoxy and Hydroxy Derivatives

Scheme 47 Synthesis of 93 and 96

Scheme 48 Synthesis of 100

45

Scheme 49 Alternate Route to 58

Scheme 50 Lithium Halogen Exchange of 1,2-Dibromobenzene

Scheme 51 Synthesis of 104

Scheme 52 Synthesis of 106

Scheme 53 Amination of 2-Methoxylapachol.

Scheme 54 Synthesis of 109

Scheme 55 Standard Buchwald Amination Conditions

Scheme 56 Expansion of Buchwald's Methodlogy

Scheme 57 Copper Catalyzed N-Arylation

Scheme 58 Synthesis of 114

Scheme 59 Synthesis of 118

Scheme 60 Reported Furan Coupling Reaction

Scheme 61 Demethylation Conditions

55

Scheme 62 Synthesis of 119 


\section{List of Tables}

Table 1 Boc-Amino Anisidine Additions

Table 2 Boc- Amino Anisidine Thermolysis

Table 3 Boc-Amino Pyridine Additions

Table 4 One Pot Thermolsys Sequence

Table 5 Pivaloyl Protected Aminopyridine Additions

Table 6 Trials for the Synthesis of $\mathbf{1 1 0}$

51 


\section{Commonly Used Acronyms}

\begin{tabular}{|c|c|}
\hline Ac & Acetyl $\left(\mathrm{CH}_{3} \mathrm{C}=\mathrm{O}\right)$ \\
\hline Boc & $t$-Butyloxycarbonyl $\left(\mathrm{COtC}_{4} \mathrm{H}_{9}\right)$ \\
\hline $\mathrm{Bz}$ & Benzoyl \\
\hline $\mathrm{Bn}$ & Benzyl \\
\hline BRSM & (yield) based upon recovered starting material \\
\hline CAN & Ceric Ammonium Nitrate \\
\hline CSA & Camphorsulfonic Acid \\
\hline DMAP & N,N-4-Dimethylaminopyridine \\
\hline DMF & $\mathrm{N}, \mathrm{N}$-Dimethylformamide \\
\hline DMSO & Dimethyl Sulfoxide \\
\hline $\mathrm{h}$ & hour(s) \\
\hline MOM & Methoxymethyl \\
\hline n-BuLi & n-Butyllithium \\
\hline Piv & Pivaloyl $\left(\mathrm{OtC}_{4} \mathrm{H}_{9}\right)$ \\
\hline Py & Pyridine \\
\hline $\mathrm{rt}$ & room temperature \\
\hline TBAF & Tetrabutylammonium fluoride \\
\hline TBDMS & t-Butyldimethylsilyl \\
\hline TBDPS & t-Butyldiphenylsilyl \\
\hline TBS & t-Butyldimethylsilyl (also TBDMS) \\
\hline t-BuLi & t-Butyllithium \\
\hline
\end{tabular}




\begin{tabular}{|c|c|}
\hline TFAA & Trifluoroacetic anhydride \\
\hline THF & Tetrahydrofuran \\
\hline TMS & Trimethylsilyl \\
\hline$\delta$ & Chemical shift (NMR) in ppm \\
\hline${ }^{13} \mathrm{C} N M R$ & Carbon-13 Nuclear Magnetic Resonance \\
\hline COSY & Correlation Spectroscopy (NMR) \\
\hline DEPT & Distortionless Enhancement by Polarization Transfer (NMR) \\
\hline $\mathrm{EI}$ & Electron Impact (MS) \\
\hline${ }^{1} \mathrm{H} N M R$ & Hydrogen-1 Nuclear Magnetic Resonance \\
\hline HETCOR & Heteronuclear Correlation (NMR) \\
\hline IR & Infrared Spectroscopy \\
\hline$J$ & Coupling Constant (NMR) \\
\hline MS & Mass spectrum \\
\hline NMR & Nuclear Magnetic Resonance \\
\hline NOE(SY) & Nuclear Overhauser Effect (Spectroscopy) \\
\hline TLC & Thin Layer Chromatography \\
\hline UV & Ultraviolet spectroscopy \\
\hline
\end{tabular}




\section{Part 1}

\section{A. Background of Naphthoquinones}

Naphthoquinone derivatives are found in a variety of natural products and pharmaceuticals, and belong to an even larger class of compounds known as quinones. ${ }^{1}$ The core structure of the quinone family is characterized by a cyclohexadiene ring system with carbonyl functionalities on the 1 and 4 carbons of the ring (Scheme 1). Naphthoquinones are a subset of quinones that have a benene ring fused to the quinone. In general, naphthoquinones are found in a variety of natural sources including fungi, bacteria, and plants. ${ }^{2}$ Some notable examples of naphthoquinones are lapachol, hybocarpone, the brazanquinones, the vitamins K's, thysanone, and the rhinacanthin (Scheme 2).

Scheme 1 Quinones and Naphthoquinones

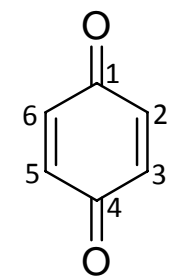

$[1,4]$ Benzoquinone<smiles>O=C1C=CC(=O)c2ccccc21</smiles>

$[1,4]$ Naphthoquinone 


\section{Scheme 2 Notable Naphthoqinones}<smiles>CC(C)=CCC1=C(O)C(=O)c2ccccc2C1=O</smiles>

lapachol<smiles>COc1cccc2c3c(oc12)C(=O)c1ccccc1C3=O</smiles>

brazanquinones<smiles>C[C@H]1CC2=C(C(=O)c3c(O)cc(O)cc3C2=O)[C@@H](O)O1</smiles>

thysanone<smiles>CC[C@]12C(=O)c3c(O)c(C)c(O)c(O)c3C(=O)[C@]1(O)O[C@]1(O)C(=O)c3c(O)c(O)c(C)c(O)c3C(=O)[C@]12C(C)C</smiles>

hybocarpone<smiles>CC(=CCC1=C(C)C(=O)c2ccccc2C1=O)CCCC(C)C</smiles>
vitamin $\mathrm{K}_{1}$<smiles>CC(C)(COC(=O)c1ccccc1)CC1=C(O)C(=O)c2ccccc2C1=O</smiles>

rhinacanthin $\mathrm{M}$

Quinones and naphthoquinones exhibit numerous biological activities. ${ }^{2}$ Commercial and pharmaceutical uses of naphthoquinones includes antipsoriatics, bone metabolism, natural dyes, antipneumococcal, antimalarial, antibacterial, trypanocidal, antitumor, antithrombotic, inhibition of angiogenesis, antimicrobial, vascular biology and regulation of blood coagulation. Much of the biological activity that naphthoquinones exhibit has been attributed to its ability to participate in electron transfer reactions whereby the core quinone structure can accept one or two electrons thus becoming a radical anion or dianion based upon the number of electrons the molecule accepts. A 1,4-naphthoquinone becomes a 1,4-naphthohydroquinone in its reduced 
form which is easily oxidized back to the corresponding naphthoquinone (Scheme 3 ). This ability to accept electrons gives naphthoquinones an extensive ability to participate in a variety of biologically important processes such as photophosphorylation and transport of electrons between various enzymes. ${ }^{2}$

\section{Scheme 3 Naphthoquinone Redox Forms}<smiles>O=C1C=CC(=O)c2ccccc21</smiles>

1,4-naphthoquinone
Reduction

Oxidation

1,4-naphthohydroquinone<smiles>Oc1ccc(O)c2ccccc12</smiles>

,4-naphthohydroquinone

\section{B. Formation of Naphthoquinones}

Syntheses of naphthoquinones have been carried out through a variety of processes

(Scheme 4). Methods of synthesis ${ }^{3}$ include Stobbe Condensations (A), [4+2] cycloadditions (B), the addition of a phthalide anion to an $\alpha, \beta$-unsaturated ketone or aldehyde using the HauserKraus annulation reaction(C), the use of a Fischer aryl carbene complex with an alkyne via the Dötz reaction (D), cyclobutendione ring expansions (E), and oxidations (F). Detailed descriptions of the methods will be discussed in the following sections. 


\section{Scheme 4 Variety of Naphthoquinones Syntheses ${ }^{3}$}<smiles></smiles>

B<smiles>[R]C1=C([R])C(=O)C=CC1=O</smiles><smiles>[R1]C(C=C)=CC</smiles><smiles>[R]C1=C([R])C(=O)c2cc([R1])ccc2C1=O</smiles><smiles>CCC</smiles><smiles>[R]C1=C([R])C(O)(c2cccc(F)c2)C1=O</smiles><smiles>[R]c1ccc2c(c1)COC2=O</smiles><smiles>C1CCC2(CC1)CCCC2</smiles><smiles>[R]C#CC</smiles><smiles>[R]c1ccc(C(=[W])OC)cc1</smiles><smiles>[R]C=C([R3])C1(O)C(=O)c2ccc([R1])cc21</smiles>

D

\section{The Dötz Reaction}

Sysnthesis of naphthoquinones using the Dötz method implements a metal-alkoxycarbene complex and an alkyne. The synthesis of the metal-alkoxycarbene is achieved by a reaction of aryllithums with group 6 metal carbonyls such as $\mathrm{Cr}(\mathrm{CO})_{6}, \mathrm{Mo}(\mathrm{CO})_{6}$, and $\mathrm{W}(\mathrm{CO})_{6}$ follow by oalkylation to form stable Fischer-type carbenes. ${ }^{4}$ Once the carbene is synthesized it can be 
exposed to an alkyne to form the corresponding hydroquinone which can then be readily oxidized to the naphthoquinone (Scheme 5).

\section{Scheme 5 Dötz Methodology}<smiles>[R]C#CCC</smiles><smiles>[R]C1=C([R])C(=O)c2ccccc2C1=O</smiles>

The utilitization of the Dötz reaction is widespread because this protocol can accommodate a variety of aryl carbenes and alkynes tolerates a variety of functional groups within each of the starting materials. In addition to benzenes, aryl carbene variations have been derived from other arenes, such as naphthalenes, indoles, furans, pyrroles, and pyrazines and have included ortho, para and meta substitution within many of them. ${ }^{4}$ Alkyne variations have encompassed alkyl, alkylsilyl, boronates, esters, ethers, amides, ketones, aryl, and acetals, among others. ${ }^{4}$ The method has also been performed under various conditions including microwave, UV irradiation, heat, and silica gel promotion to form the hydroquinone. Some notable examples of the Dötz method for syntheses of naphthoquinones are found in the synthesis of shikonin ${ }^{5}$ and the natural product, 2-(1,1-dimethyl-2-propenyl)-3-hydroxy1,4-naphthalenedione, isolated from calceolaria andina $L .{ }^{6}$ In both of the syntheses the reaction is used as a convergent point. Note that a nitro and a ketal group remain unaffected during the Dötz reaction (Scheme 6). 


\section{Scheme 6 Dötz Protocol in the Shikonin and Calceolaria Andina L Syntheses.}<smiles>C#CC(C)(C)CC[Se]c1ccccc1[N+](=O)[O-]</smiles>

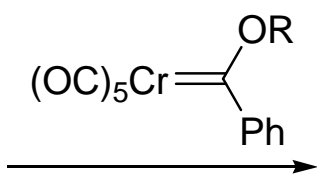<smiles>CC(C)(CC[Se]c1ccccc1[N+](=O)[O-])C1=CC(=O)c2ccccc2C1=O</smiles><smiles>C1=CC=C1</smiles><smiles>C=CC(C)(C)C1=C(O)C(=O)c2ccccc2C1=O</smiles>

calceolaria andina $L$<smiles>C#C[C@H]1COC(C)(C)O1</smiles><smiles>CC(C)=CC[C@H](O)C1=CC(=O)c2c(O)ccc(O)c2C1=O</smiles>

\section{The Hauser-Kraus Annulation Reaction}

Another method of preparation of napthoquinones includes the use of the Hauser-Kraus annulation reaction. This method entails the addition of a phthalide anion that is added to an $\alpha, \beta$-unsaturated ketone or aldehyde which acts as a Michael acceptor (Scheme 7). The anion created from the Michael addition then attacks the carbonyl of the phthalide forming a third ring. An alkoxide promoted ring opening then occurs with the elimination of the leaving group. Through tautermization the hydroquinone is formed and aromaticity is gained. Finally, using various oxidation protocols, the napthoquinone is obtained. 


\section{Scheme 7 Hauser-Kraus Annulation Reaction}<smiles>[R]C(=O)C=C([R3])C[C@]1([R1])OC(=O)c2ccccc21</smiles><smiles>[R]C(=O)C1C(=O)c2ccccc2C(=O)C1[R3]</smiles><smiles>[R]C(=O)c1c([R3])c(O)c2ccccc2c1O</smiles><smiles>[GeH2]C=[GeH2]</smiles>

This method accommodates a variety of functional groups on the phthalides including cyano, ${ }^{7}$ sulfide $^{7}$ and sulfone ${ }^{8}\left(R_{1}\right)$ groups. An interesting use of this method can be seen in the asymmetric synthesis of both alkannin and shikonin $^{9}$ (Scheme 8$)$. This synthesis utilizes LDA as the base to form the cyanophthalide anion. Upon the Michael addition and elimination of cyanide, the hydroquinone core is established. 


\section{Scheme 8 Hauser-Kraus Annulation in the Assymetric Synthesis of Alkannin and Shikonin}<smiles>C=CC(=O)CC=C(C)CC(C)C(F)F</smiles><smiles>COc1ccc(OC)c2c(O)c(C(=O)CC=C(C)C)cc(O)c12</smiles><smiles>CC(C)=CC[C@@H](O)c1cc(O)c2c(c1O)C(=O)C=CC2=O</smiles>

Alkannin<smiles>CC(C)=CC[C@@H](O)c1cc(O)c2c(c1O)C(=O)C=CC2=O</smiles>

Shikonin

\section{Cycloaddition Reaction}

Another method of generating naphthoquinones is the use of a [4+2] cycloaddition reaction. The most common procedure is the cycloaddition employing quinones as the dienophile reacting with a substituted diene (Scheme 9). ${ }^{10}$ However, there are reported syntheses utilizing vinyl quinones as dienes. ${ }^{11}$ Generally, the quinone dienophile is reacted with the diene to afford a bicyclic $\alpha, \beta$-unsaturated diketone. The initial nonaromatic product can be subjected to various oxidation-elimination conditions to afford the corresponding naphthoquinones. Common oxidation-elimination reagents include air, ${ }^{12}$ silica gel, ${ }^{13} \mathrm{chromium}$ oxide, ${ }^{14}$ and manganese oxide. ${ }^{15}$ 


\section{Scheme 9 [4+2] Cycloaddition Reaction Method}

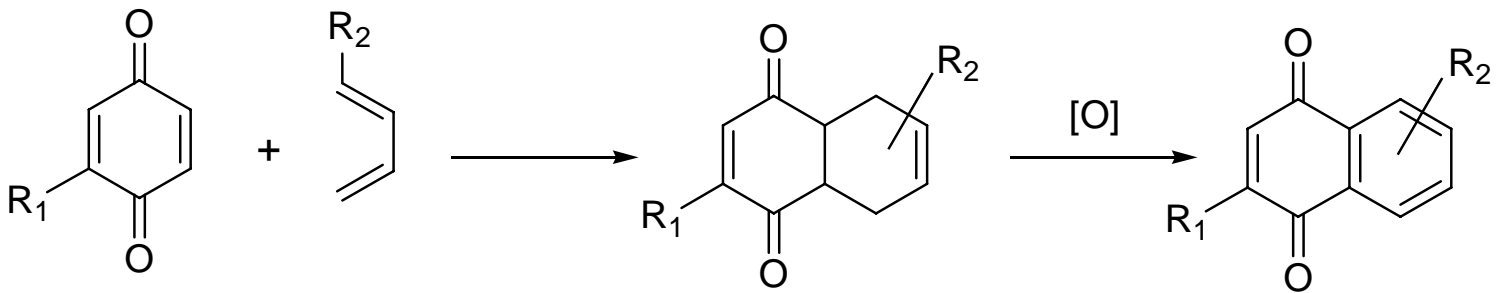

When unsymmetrical quinones and dienes are used the regiochemistry has been shown to be directed by electronic effects. However, prediction of the regiochemistry is not possible for all substrates because of its dependence on the diene, dienophile, Lewis acids and solvent. ${ }^{3}$ In particular the diene can be substituted with an alkoxy, ${ }^{16}$ silyoxy, ${ }^{17}$ or halogen group ${ }^{18}$ as well as vinyl aryl, ${ }^{19}$ vinyl furans ${ }^{20}$ and vinyl pyroles. ${ }^{21}$ In addition to the use of quinones as dienophiles, alternate reaction conditions have include quinones being ulitized as a diene ${ }^{11}$ (Scheme 10) and as well as benzynes ${ }^{22}$ have been reported as dienophiles (Scheme 11).

\section{Scheme 10 Quinone Diene Method}

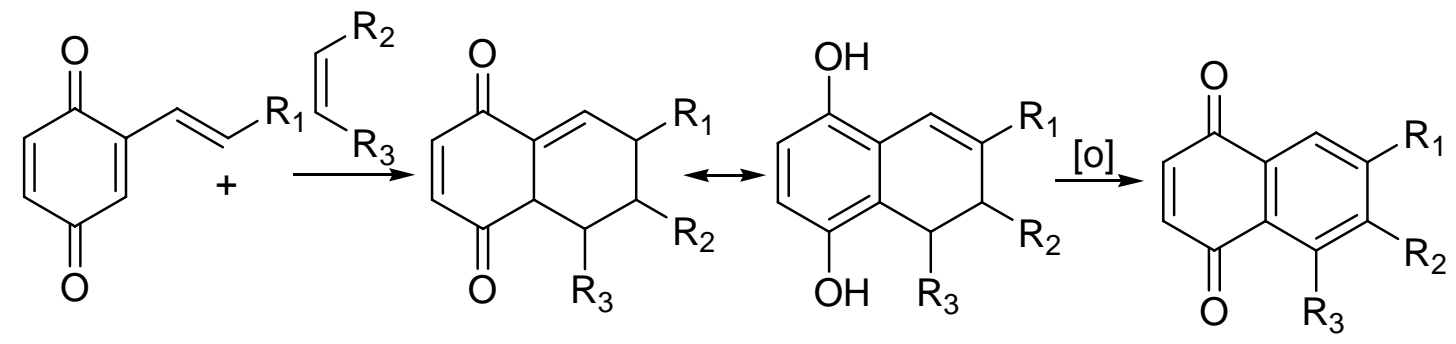

\section{Scheme 11 Benzyne Dienophile Method}<smiles></smiles> 
Application of the [4+2] cycloaddition can be seen in a variety of syntheses of biologically important molecules such as the synthesis of crisamicin A. ${ }^{23}$ (Scheme 12) This method accommodates a pyran fused lactone quinone dienophile and an activated diene. The lactone was exposed to the diene promoting the cyclization, then the cyclized product was oxidized to provide the naphthoquinone. One key point to recognize is this synthesis was accomplished with a high regioselectivity (>20:1). The author attributes the success of the reaction to the stereoelectronic differentiation that is evident between the two quinone carbonyls as being dictated by the pyran fused lactones moieties.

\section{Scheme 12 Synthesis of Crisamicin A.}

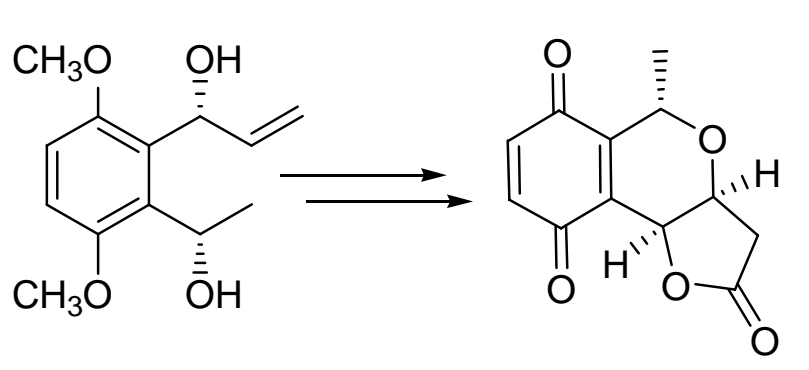<smiles>C=C(C=C(OC)OC)OC</smiles>

2. Jones Reagent

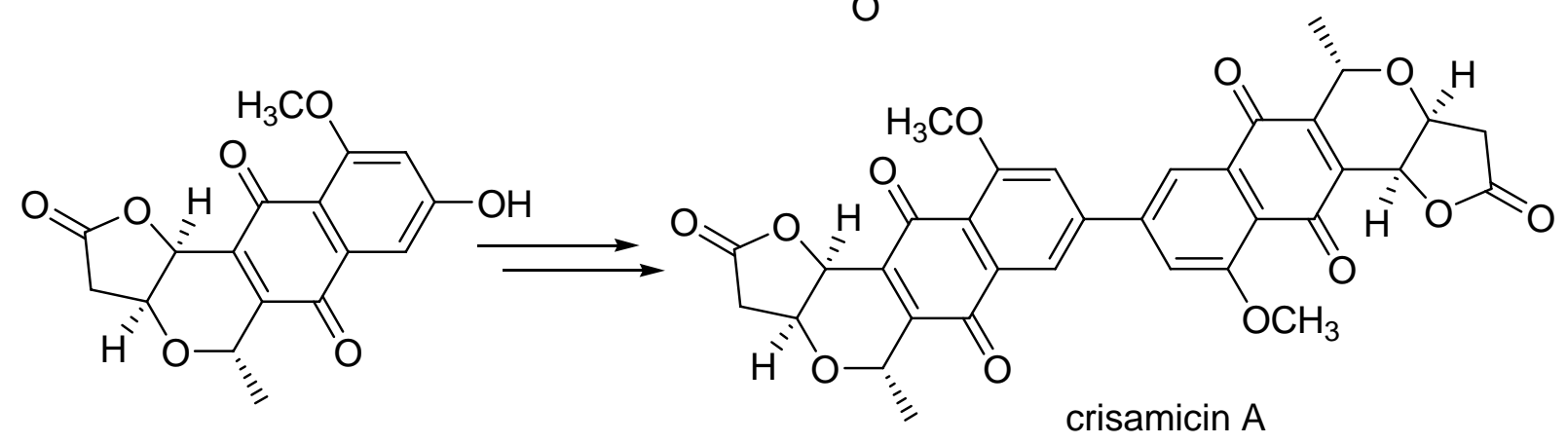

\section{Stobbe Condensation}

This condensation method involves the reaction of succinic acids with benzaldehydes followed by Friedel Craft acylations providing the naphthalene core (Scheme 13). Upon saponification and oxidations, the quinones are obtained. A limitation of the method is that the 
E isomer of the obtained from the condensation can only participate in the Friedel-Craft reactions and therefore the double bond geometry is a key to the success of the reaction. ${ }^{3}$

\section{Scheme 13 Stobbe Condesation}

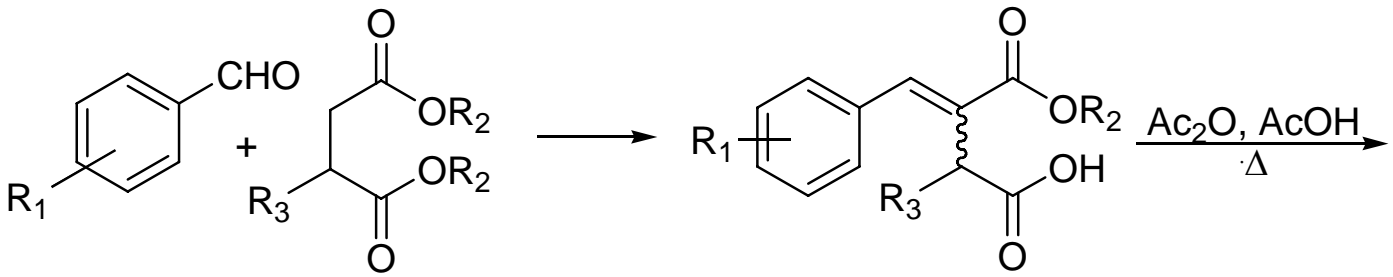<smiles>[R6]OC(=O)c1c(C([R20])=O)cc2c(c1OC([R])=O)C=C[R1]C=C2</smiles>

One highlighted example recently reported using of the Stobbe condensation is in the synthesis of ventiloquinone $F$ and isoventiloquinone $F$ (Scheme 14). ${ }^{24}$ The initial step of the synthesis is a Stobbe condensation between 2,4,5-trimethoxy benzaldehyde and dimethyl succinate under basic conditions to yield a hydronaphthoquinone which is oxidized later in the synthesis to afford the naphthoquinone core of both ventiloquinone $F$ and iosventiloquinone $F$. 


\section{Scheme 14 Synthesis of Ventiloquinone and Isoventiloquinone}<smiles>COc1cc(OC)c(OC)cc1C=O</smiles>

1. dimethyl succinate

$\underset{\mathrm{KOtBu}, \mathrm{t}-\mathrm{BuOH}}{\mathrm{NaOAc}, \mathrm{Ac}_{2} \mathrm{O}}$<smiles>COC(=O)c1cc(OC)c2c(OC)c(OC)cc(OC)c2c1</smiles><smiles>C=CCc1c(C=O)cc2c(OC)cc(OC)c(OC)c2c1OCCCCCCCCCC</smiles><smiles>COC1=CC(=O)c2cc3c(c(OCc4ccccc4)c2C1=O)C[C@H](C)O[C@@H]3C</smiles>

ventiloquinone $\mathrm{F}$<smiles></smiles>

isoventiloquinone $\mathrm{F}$

\section{Cyclobutenedione Rearrangements}

Cyclobutenediones have been shown to be useful intermediates in quinone syntheses. This method requires the use of a cyclobutenedione which accepts a variety of nucleophiles to form 4-hydroxycyclobutenones (Scheme 15). When the 4-hydroxycyclobutenones are thermolyzed, they afford hydroquinones that can be readily oxidized to form quinones. This method includes numerous variations and is therefore a useful synthetic method for quinones and has been expanded for the synthesis of naphthoquinones. ${ }^{3}$ 


\section{Scheme 15 General Thermal Rearrangements of 4 hydroxycyclobutendiones.}<smiles>[R]C#CCC1(O)C(=O)C([R1])=C1[R1]</smiles>

When benzocyclobutenediones are employed, three general variations have been shown to provide naphthoquinones (Scheme 16). First, when alkenes are added to benzocyclobutenedione followed by thermal rearrangement and oxidation, they can generate naphthoquinones having subtituents on both the quinone and phenyl rings (Scheme 16, A). ${ }^{25}$ Similarly, when alkyne nucleophiles are added to benzocyclobutenediones they can also form fully substituted naphthoquinones after thermolysis and oxidation (Scheme $16, B) \cdot{ }^{26}$ A final use of benzocyclobutenediones is the exposure of the cyclobutendione to low valent metals to generate metallocycles (Scheme 16, C). When the metallocycles are reacted with alkynes, the reaction affords the naphthoquinones directionly and therefore the oxidation step necessary for many naphthoquinone syntheses is eliminated. 


\section{Scheme 16 Strategies for Forming Substituted Naphthoquinones from Cyclobutendiones}<smiles>[R]C#CC#CC[R]([R])c1ccc2c(c1)C(=O)C([R])=C([R])C2=O</smiles>

Cyclobutenediones, as opposed to benzocyclobutenediones, can be used to form naphthoquinones when aryl groups are added to them (Scheme 17). ${ }^{25}$ Variations in this system can come from substituents on the aryl group or on the cyclobutendione.

\section{Scheme 17 General Aryl Addition-Rearrangement}<smiles>[R]Cc1ccc(C2(O)C(=O)C([R1])=C2[R])cc1</smiles>

The mechanisms for all thermal rearrangement of 4-hydroxycyclobutenediones begin with a retro [2+2] electrocyclic cleavage to form ketene intermediates (Scheme 18). When alkenes and aryl groups are introduced, then retro [2+2] cycloaddition takes place, followed by an 
electrocyclic ring closure. This intermediate then tautomerizes to form the hydroquinone.

During the final step the hydroquinone is oxidized, either by the addition of oxidative reagents or by simple exposure to air, to form naphthoquinones.

Scheme 18 Alkene Rearrangement Mechanism<smiles>[R]C=C([R3])C1(O)C(=O)C([R])=C1C([R])=CC</smiles><smiles>[R]C1=C([R])C([R])C([R])=C([R])C1=O</smiles>

In the case of alkynyl substituted cyclobutenones, the mechanism is slightly different. After a retro [2+2] cycloaddition, the reaction products can be explained through a zwitterion or radical intermediate (Scheme 19). In the zwitterion case a, the lone pair of electrons on oxygen promote a ring closure forming the zwitterion. Upon migration of the alkoxide group, the synthesis affords the naphthoquinone without oxidation. 
Scheme 19 Alkyne Rearrangement Mechanism<smiles>[R]C#CC1(O[R3])C(=O)c2c(C)cccc21</smiles><smiles>[R]O[C@H]1C=C([R])C(=O)c2ccccc21</smiles>

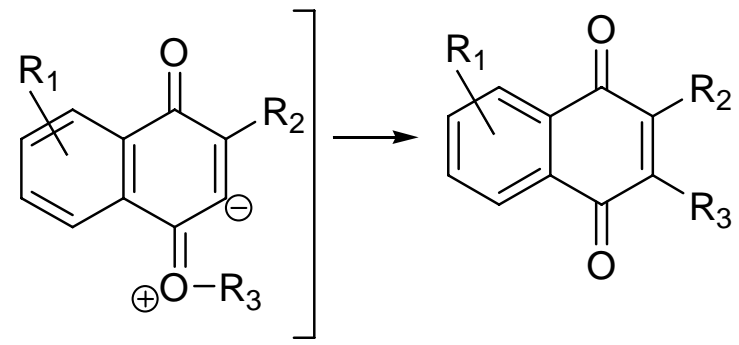

An example of the use of a benzocyclobutenedione can be found in a report by Moore for the synthesis of deoxyfrenlicin (Scheme 20). ${ }^{26}$ In the synthesis an alkyne nucleophile was added to 3-methoxybenzocyclobutene-1,2-dione and then was subjected to thermal rearrangement conditions. After the construction of a cyclic ether and a lactone they afford, deoxyfrenolicin was obtained.

\section{Scheme 20 Deoxyfrenolicin Synthesis}<smiles>COc1cccc2c(=O)c(=O)c12</smiles>

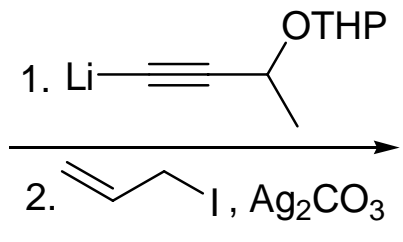<smiles>C=CCOC1(C#CC(C)[OH+])C(=O)c2c(OC)cccc21</smiles><smiles>C=CCC1=C(C(C)[OH2+])C(=O)c2ccccc2C1=O</smiles><smiles>CCCC1OC2CC(=O)OC2C2=C1C(=O)c1c(O)cccc1C2=O</smiles> 
The final example of the utility of benzocyclobutenedione in naphthoquinone synthesis involves the formation of a metallocycles. Benzocyclobutenedione is exposed to low valent metal complexes where the metal inserts between both carbonyls of benzocyclobutenediones ${ }^{27}$ (Scheme 21). Alkynes can insert into the benzometallocycles and then the metal can reductively eliminate to form naphthoquinones without oxidation.

\section{Scheme 21 Benzometallocycle Methodology}

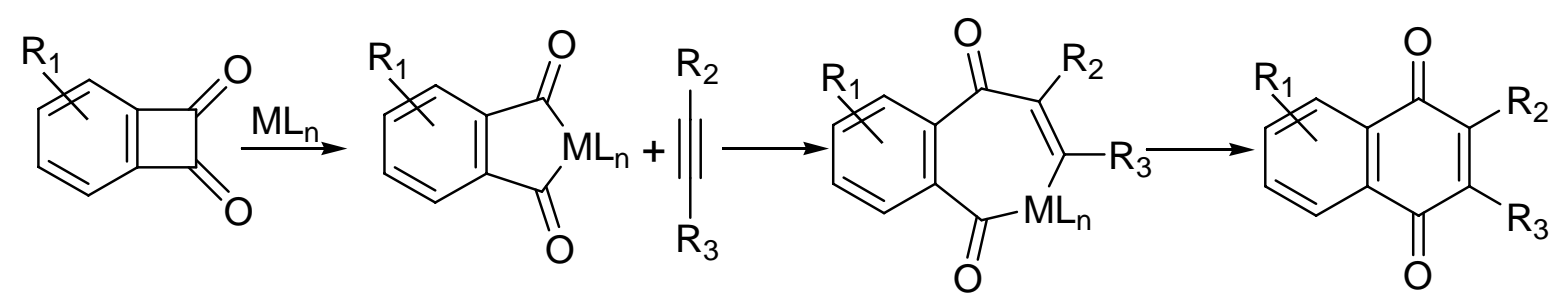

Use of the method can be found in Liebeskind's synthesis of nanomycin A (Scheme 22). ${ }^{28} \mathrm{An}$ alkyne nucleophile is added to 3-hydroxybenzocyclobutene-1,2-dione. The cobalt metallocycle is constructed and then employed for the synthesis of the naphthoquinone core. 
Scheme 22 Nanaomycin A Synthesis

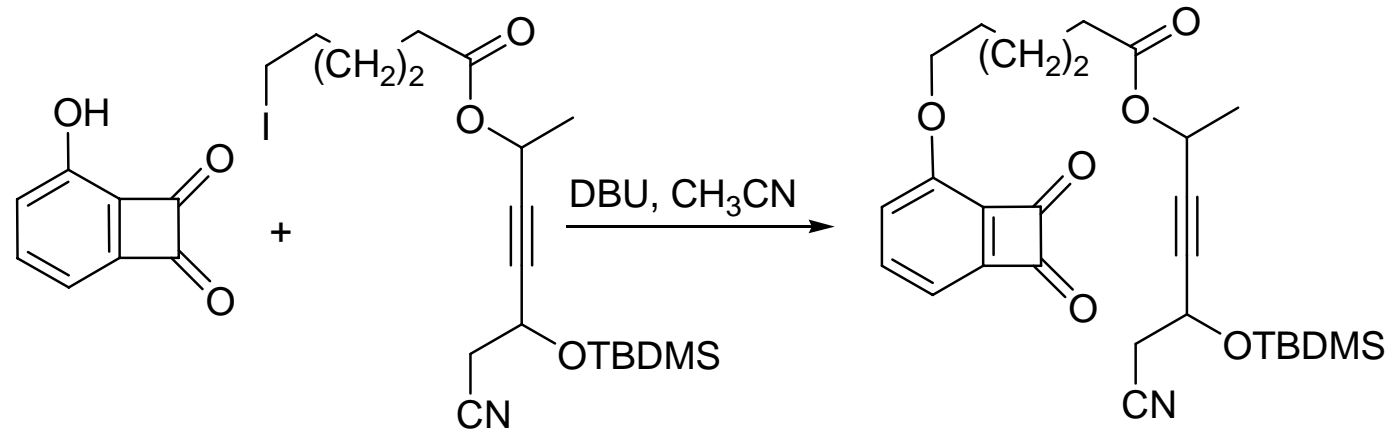

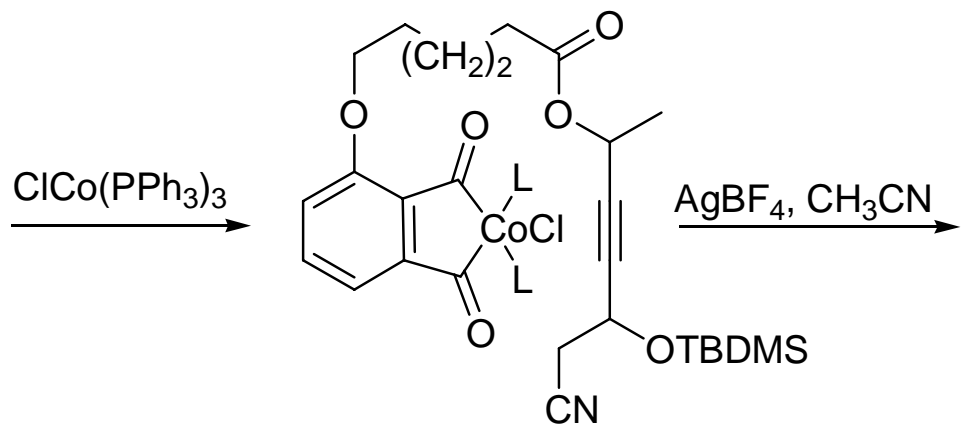

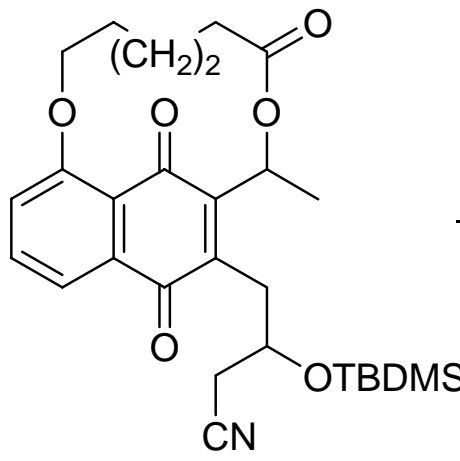<smiles>C[C@H]1O[C@H](CC(=O)O)CC2=C1C(=O)c1c(O)cccc1C2=O</smiles>

nanaomycin A 


\section{Part 2 Results and Discussion}

\section{Chapter 1 Ortho-Lithiation Directed Addition-Thermoylsis.}

With the intention of exploring thermally induced benzannulations of aminoaryl substituted cyclobutenones, the addition of substituted anilines to substituted cyclobutenediones were initially examined (Scheme 23).

\section{Scheme 23 Proposed Synthesis of Aminonaphthoquinones}<smiles>[R3]c1c([R2])c(=O)c1=O</smiles>

1

Experimentation began with the focus on the dianion addition of carbamate aniline 4 to diisopropyl squarate. This protocol was used to allow the carbamate to direct the ortholithiation with the carbamates intention of creating the ortho-substituted Boc-aniline $\mathbf{5}$. Therefore, aniline was protected using di-tert-butyl dicarbonate and potassium carbonate in THF: $\mathrm{H}_{2} \mathrm{O}$ (Scheme 24). ${ }^{29}$ With the protected aniline 4 now available, an ortho-lithiation protocol was used with 6 equivalents of t-BuLi at $-78{ }^{\circ} \mathrm{C}$ for $4 \mathrm{~h}$ then adding diisopropyl squarate. It is unknown why the reaction needed 6 equivalents of base but it was found to be in agreement with a literature report ${ }^{30}$ using excess t-BuLi to optimize ortho-lithiations of 4. With 6 equivalents, the reaction proceeded to afford the addition product 5 in a $73 \%$ yield, however, N-(tert-butyloxycarbonyl)-aniline was usually recovered. It was also determined that the reaction was most effective when the reaction was quenched with $10 \% \mathrm{NH}_{4} \mathrm{Cl}$ in $\mathrm{H}_{2} \mathrm{O}$. This thermolysis precursor was now ready for cyclization and was heated in xylenes at $170{ }^{\circ} \mathrm{C}$. The 
reaction proceeded to completion in $3 \mathrm{~h}$ as monitored by TLC and was found to have created the naphthoquinone 6 in $81 \%$ yield.

\section{Scheme 24 Carbamate Protected Aniline Addition-Thermolysis}
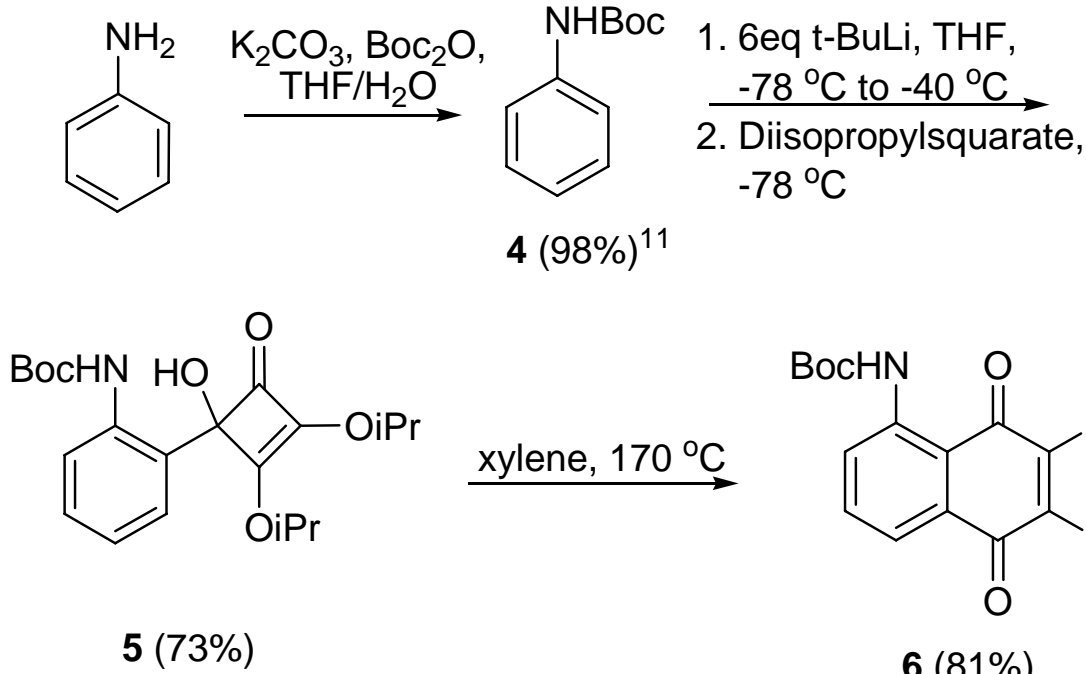<smiles>CC(C)OC(=O)Nc1cccc2c1C(=O)C(OC(C)C)=C(OC(C)C)C2=O</smiles>

$6(81 \%)$

Given the early success of the methodology, it was envisioned that various aniline derivatives could be prepared in an analogous manner. The first compounds that were studied were the methoxy substituted $\mathrm{N}$-(tert-butyoxycarbonyl) anilines. The ortho, meta, and para anisidines were protected as described for compound 4, a reaction that proceeded in high yields affording the corresponding protected derivatives 7, 8, and 9 in 98,94 and $92 \%$ respectively (Scheme $25)^{29}$

Scheme 25 Aminoanisidine Carbamate Protection

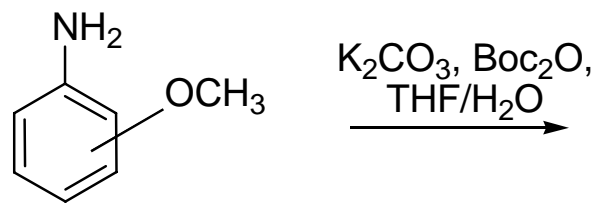<smiles>COc1ccccc1NC(C)(C)C</smiles>

ortho-7 (98\%) meta-8 (94\%) para-9 (92\%) 
The focus then turned to the ortho-lithiation-additions to diispropylsquarate. The protected aminoanisidines $\mathbf{7}, \mathbf{8}$, and $\mathbf{9}$, were subjected to t-BuLi at cold temperatures and then diisopropyl squarate was added (Table 1). Subjecting the anisidine derivatives to the addition reactions was not as straightforward as in the initial study. It was discovered that the methoxy group competed with the carbamate as the ortho directing group. In each of the reactions, addition of squarate was observed adjacent to the carbamate, but it was also observed ortho to the methoxy group. In the case of the meta-anisidine derivative, a third product was also observed with the third product 14 being directed by both the carbamate and the methoxy group. In addition to the mixture of products, starting material was recovered in all cases. 


1. 3-4 eq t-BuLi, THF,
$\begin{aligned} & -78^{\circ} \mathrm{C} \text { to }-40^{\circ} \mathrm{C} \\ & \text { 2. Diisopropylsquarate, } \\ & -78^{\circ} \mathrm{C}\end{aligned}$<smiles>COc1ccccc1NC(=O)OCc1cccc(C(C)(C)C)c1NC(=O)OC1=C(OC(C)C)C(O)(c2cccc(OC(C)(C)C)c2Nc2ccccc2)C1=O</smiles>

7

$10(30 \%, 40 \%$ BRSM)

$11(15 \%, 20 \%$ BRSM)<smiles>COc1cccc(NC(=O)OCc2ccccc2)c1</smiles>

$14(12 \%, 16 \%$ BRSM)<smiles>CCCOC1=C(OC(C)C)C(O)(c2cc(NC(=O)OC(C)C)ccc2OC)C1=O</smiles>

With a variety of hydroxycyclobutenones available, $\mathbf{1 0}, \mathbf{1 1}, \mathbf{1 2}$, and 15 were subjected to standard thermoylsis conditions at temperatures between $170{ }^{\circ} \mathrm{C}$ and $180{ }^{\circ} \mathrm{C}$ in xylenes (Table 
2), a manner analogous to the initial system (Scheme 24). This set of reactions also did not mimic the success of the original system. The yields were within the $21 \%$ to $30 \%$ range as compared to $81 \%$ obtained in the original system. It is unknown why the reactions did not mimic the original success.

Table 2 Boc-Aminoanisidine Thermolysis

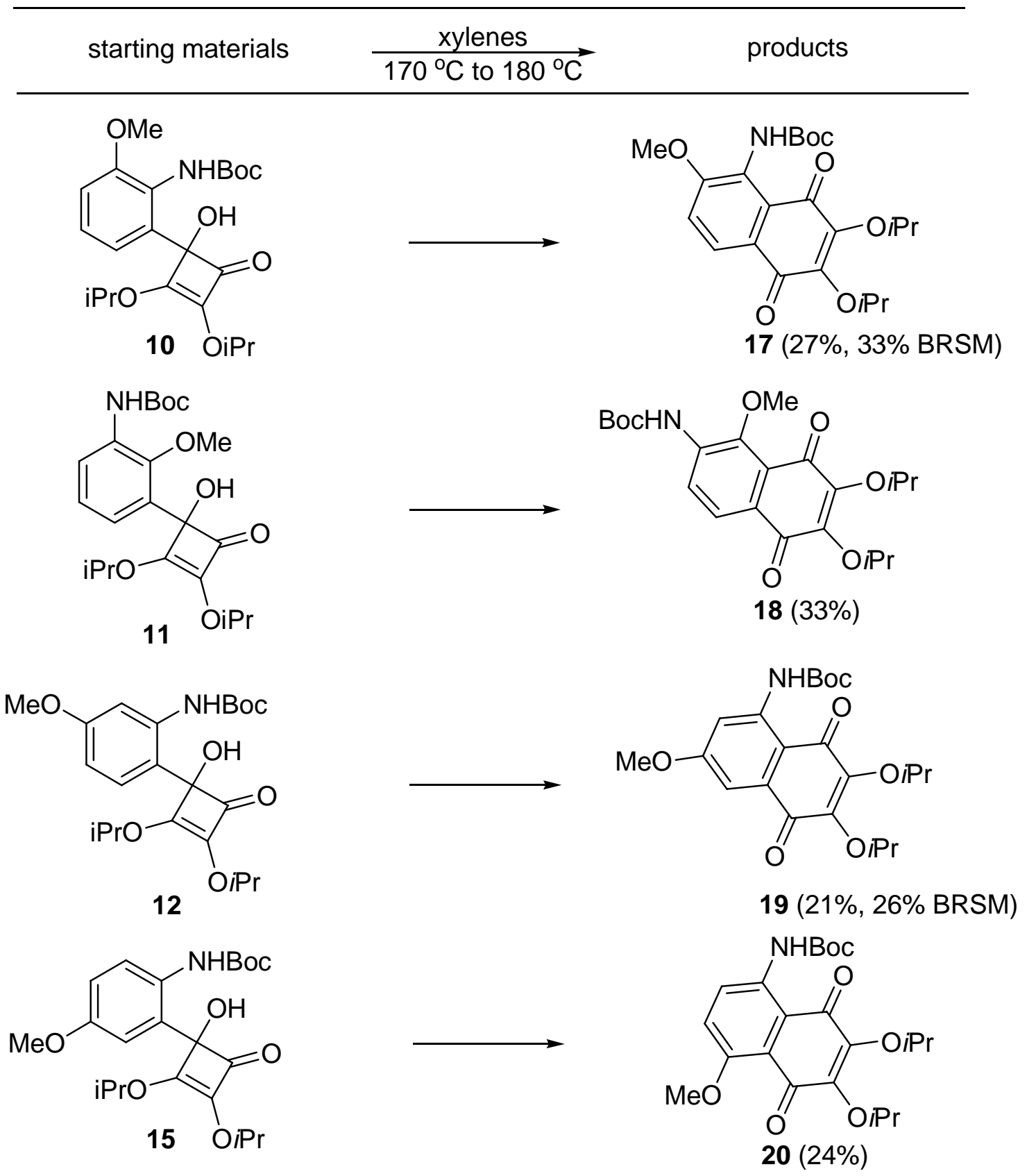


Amino substitutes pyridines were examined in an attempt to explore more electron rich molecules and potentially expand the library of compounds. Carbamate protection of 2-, 3-, and 4-amino pyridines was accomplished by a protocol reported by Lowary where the aminopyridines were exposed to di-tert-butyldicarbonate in tert-butyl alcohol (Scheme 26). ${ }^{31}$ Each of the protections worked as expected to afford the corresponding amino-protected compounds 21, 22, and 23 in 98, 93, and 91\% yields, respectively.

\section{Scheme 26 Carbamate Aminopyridine Protection}

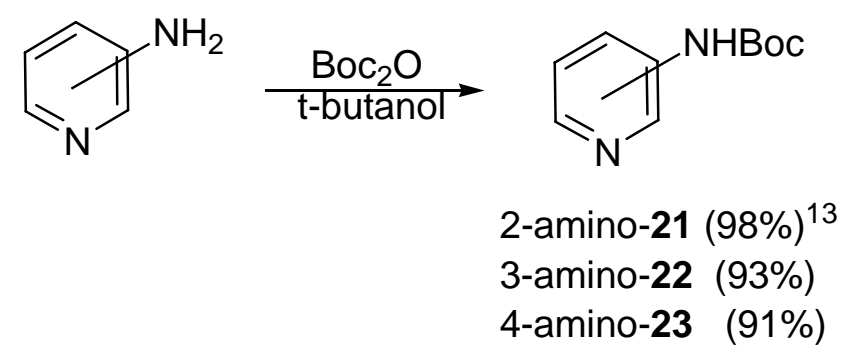

It was envisioned that using a similar method to the original ortho-lithiation protocols, the protected amino pyridines could afford compounds analogous to the previously described substrates (Table 3). While this was the case, $\mathbf{2 4}, \mathbf{2 5}$, and $\mathbf{2 6}$ were synthesized but the compounds were very unstable. Purification was a challenge because of streaking on column chromatography and TLC, even with the exploration of alumina to eliminate acid-base interactions. In addition to complications during purification, the compounds were not stable upon storage. 


\section{Table 3 Boc-Amino Pyridine Additions}

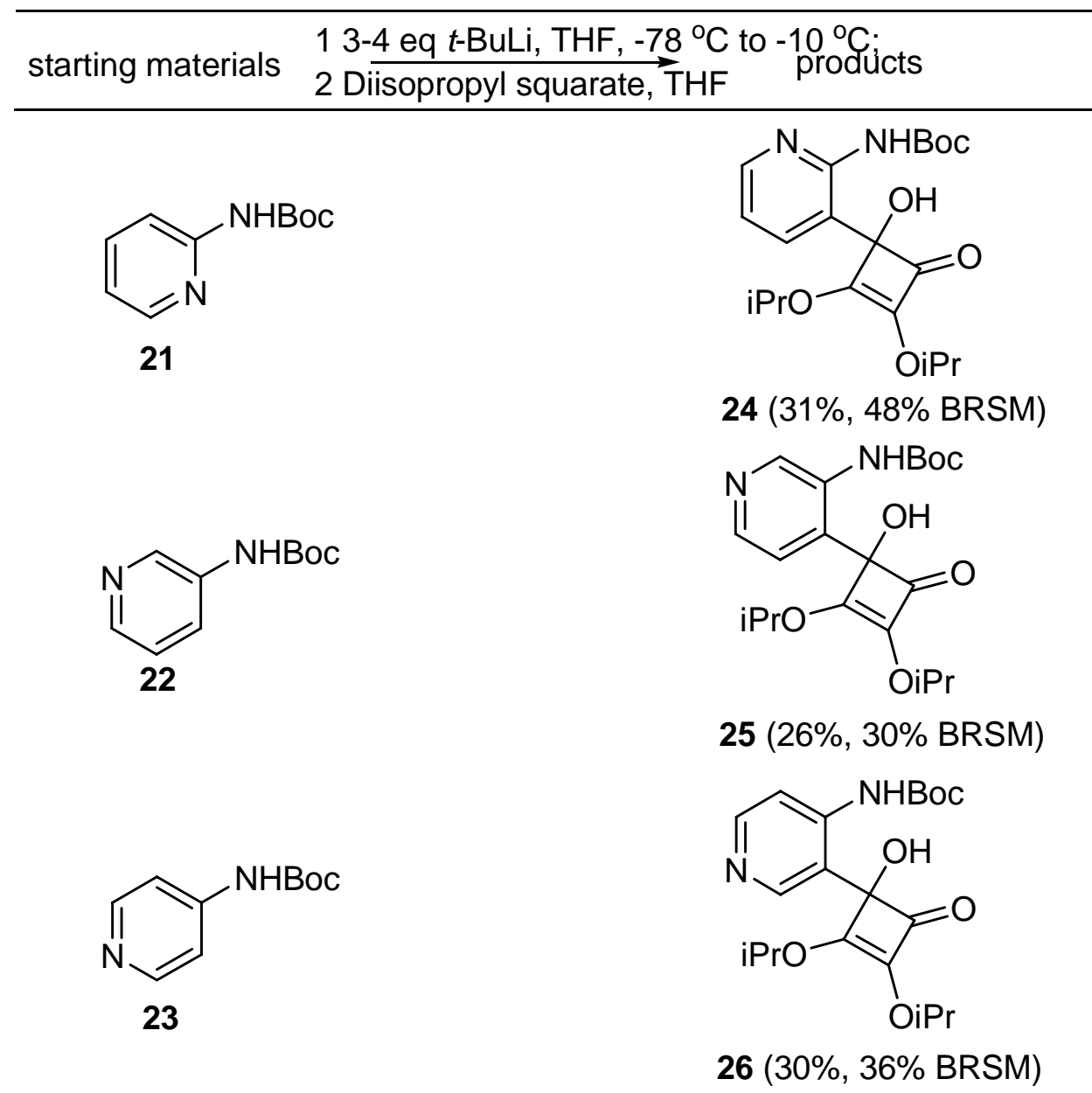

With evidence of the intermediate alcohols 24-26 by ${ }^{1} \mathrm{H}$ NMR spectroscopy of the crude product and having isolated of small amounts of the compounds 24-26 it was known that some addition to diisopropylsquarate was occurring. With this knowledge and the poor stability of the products, it was decided that the hydroxycyclobutendones should be subjected to thermal rearrangement conditions as crude mixtures. The 4-amino-substituted anisidine 9 and 4amino-substituted pyridine $\mathbf{2 3}$ were thermolyzed without purification of the intermediate addition products (Table 4). The para substituted derivatives were selected because regardless of the ortho-lithiation director, carbamate or methoxy, the reactions would afford the same 
naphthoquinone products $\mathbf{2 0}$ and $\mathbf{2 7}$. The sequence proved to be a possible method for synthesis of the desired compounds. However, because of the low yields, it seemed not to be the most efficient method for the synthesis of the amino substituted naphthoquinones.

Table 4 One Pot Thermolysis Sequence

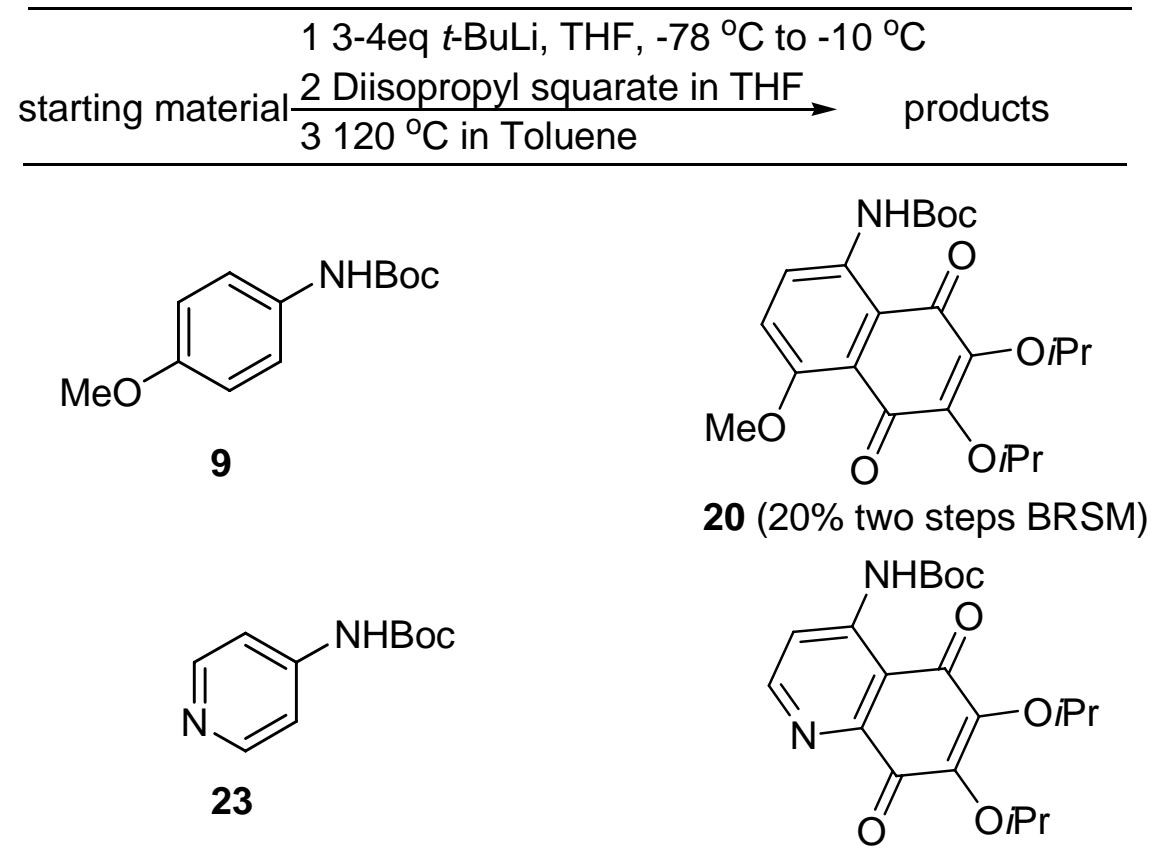

27 (31\% two steps BRSM)

With questions of the carbamate protecting group's directing ability during the ortho-

lithiation, it seemed necessary to explore other amine protecting groups. The amino pyridines were protected with a pivaloyl group by a reported method ${ }^{32}$ where amino pyridines in methylene chloride were exposed to pivaloyl chloride in the presence of triethylamine. The pivaloyl protected amino pyridines were reacted with t-BuLi followed by the addition of diisopropyl squarate (Table 5). The reactions yielded the desired compounds $\mathbf{3 1}, \mathbf{3 2}$, and $\mathbf{3 3}$ and they were subjected to thermolysis. Unfortunately the naphthoquinones were not observed aside from the trace amounts of napthoquinone $\mathbf{3 4}$. 


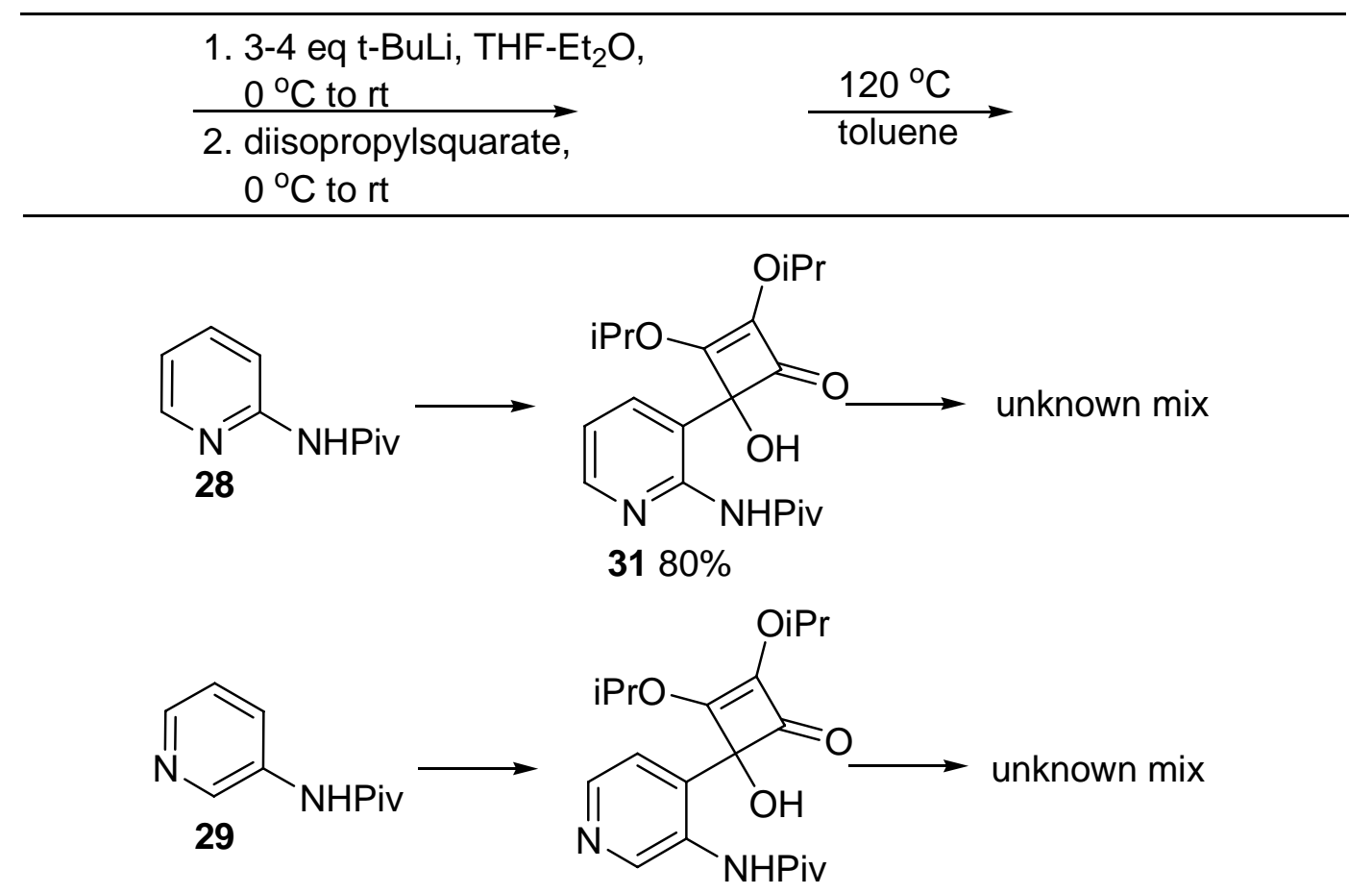

32 14\%<smiles></smiles>

33 91\%

34 trace amts

With an apparent need to return to a less functionalized system, aniline was then protected with a pivaloyl group. It was thought that using the parent aniline derivative would allowed a better understanding of the effectiveness of the ortho-lithiation and thermolysis conditions. After standard protections, ${ }^{33}$ aryl amide $\mathbf{3 5}$ was subjected to the ortho-lithiation conditions then reacted with diisopropylsquarate to afford the hydroxycyclobutenone 36 in $45 \%, 67 \%$ BRSM (Scheme 27). Compound 36 underwent thermolysis in the presence of proton sponge. ${ }^{34}$ Proton sponge has been reportedly used to eliminate acid catalyzed reactions. ${ }^{34}$ The reaction 
gave a $40 \%$ yield of the desired naphthoquinone 37 when performed at $120^{\circ} \mathrm{C}$. Notably, when the reaction was performed at $170{ }^{\circ} \mathrm{C}$ one of the isopropyl groups was lost during the reaction. Naphthoquinone alcohol $\mathbf{3 8}$ was elucidated via x-ray crystallography to determine which isopropyl group was removed and to ensure that the proposed structure was correct (Figure 1). At the time of this report, the reason for selectivity has not been determined.

\section{Scheme 27 Pivaloyl Protect Aniline Addition Thermolysis}<smiles>Nc1ccccc1</smiles>

$\underset{\mathrm{NEt}_{3}, \text { pivaloyl chloride, }}{\stackrel{0^{\circ} \mathrm{C}, 1 \mathrm{~h}}{\longrightarrow}}$<smiles>PNc1ccccc1</smiles>

$35(91 \%)$
1. 3 eq n-BuLi, THF-

$$
\mathrm{Et}_{2} \mathrm{O}, \mathrm{O}^{\circ} \mathrm{C} \text { to rt }
$$$$
\underset{\substack{\text { 2. diisopropyl } \\ \text { squarate, }}}{20 \mathrm{hr}}
$$

squarate,

$0{ }^{\circ} \mathrm{C}$ to rt $4 \mathrm{~h}$<smiles>CC(C)OC1=C(OC(C)C)C(O)(c2ccccc2N)C1=O</smiles>

36 (45\% 67\% BRSM)

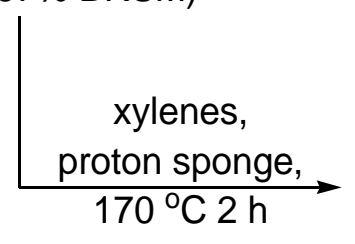

$\underset{\text { xylenes, proton sponge, }}{120^{\circ} \mathrm{C} 2 \text { days }}$<smiles>CC(C)Nc1cccc2c1C(=O)C(OC(C)C)=C(OC(C)C)C2=O</smiles>

$37(40 \%)$<smiles>CCCNc1cccc2c1C(=O)C(OC(C)C)=C(O)C2=O</smiles>

38 (64\%) 
Figure 1 X-Ray Crystal Structure of 37

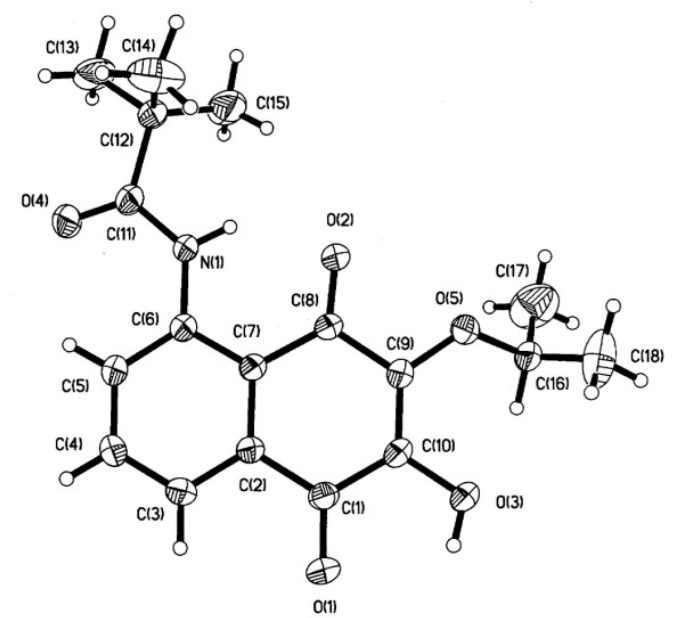

As an extension of the addition-thermal rearrangment methodology, functional groups other than protected amines were explored. The first idea came from a report where Knochel used phenylmagnesium chloride as a reagent for iodine magnesium exchanges (Scheme 28). ${ }^{35}$ In addition to the ease of halogen exchange, that the paper reports the incorporation of a variety of functional groups attached to the nitrobenzenes by the addition of the appropriate electrophile.

\section{Scheme 28 Nitrobenzene Halogen Exchange Protocol $^{17}$}<smiles>O=[N+]([O-])c1cc(C(F)(F)F)ccc1I</smiles>

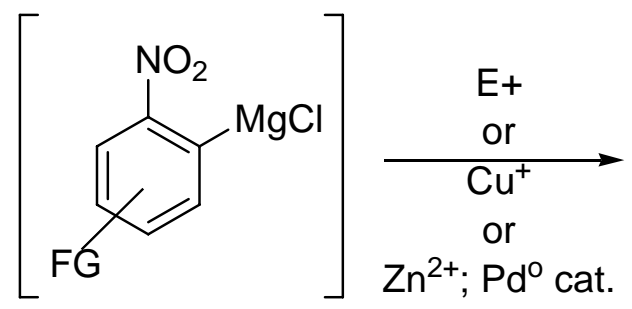<smiles>O=[N+]([O-])c1cc(F)ccc1F</smiles>

2-Iodo-nitrobenzene was subject to the Knochel protocol of iodine-magnesium exchange at $-40^{\circ} \mathrm{C}$ for 5 to $10 \mathrm{~min}$, then diisopropyl squarate in THF was added via a cannula (Scheme 29). The method proved to be successful and the desired addition product 39 was obtained in $72 \%$ yield. Compound 39 was heated at $160{ }^{\circ} \mathrm{C}$ in xylenes and the reaction went to completion in 1 
h. Upon full characterization, the molecule was found to be the hydroxyquinonlinone $\mathbf{4 0}$ in $65 \%$ yield.

\section{Scheme 29 NitroBenzene Addition-Thermolysis}

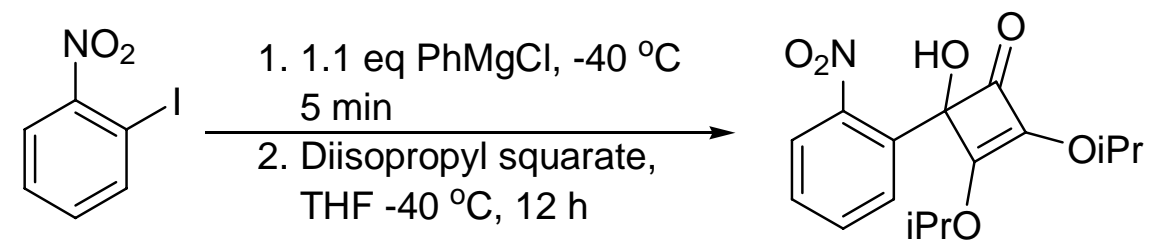

$39(72 \%)$

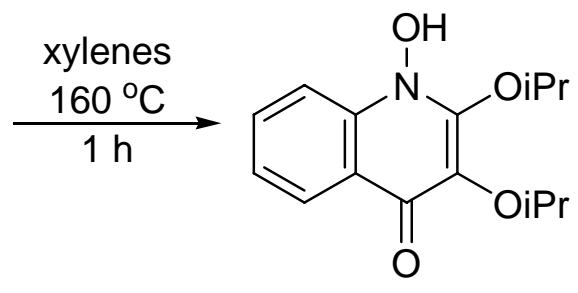

$40(65 \%)$

The proposed mechanism for the synthesis of the hydroxyquinolinone $\mathbf{4 0}$, begins with a retro [2+2] cycloaddition, similar to those in the previously reported mechanisms, to form the intermediate $\mathbf{4 2}$ (Scheme 30). From there, the nitro group attacks the newly formed ketene $\mathbf{4 2}$ to give the cyclized intermediate $\mathbf{4 3}$. Ring opening produce resonance structure $\mathbf{4 4}$ and $\mathbf{4 5}$. A second ring closure is accomplished via a nitroso attack an the carbocation to form the cyclized intermediate 46. Decarboxylation followed by deprotonation-protonation would provide the isolated product 49 . 


\section{Scheme 30 Nitrobenzene Proposed Mechanism}

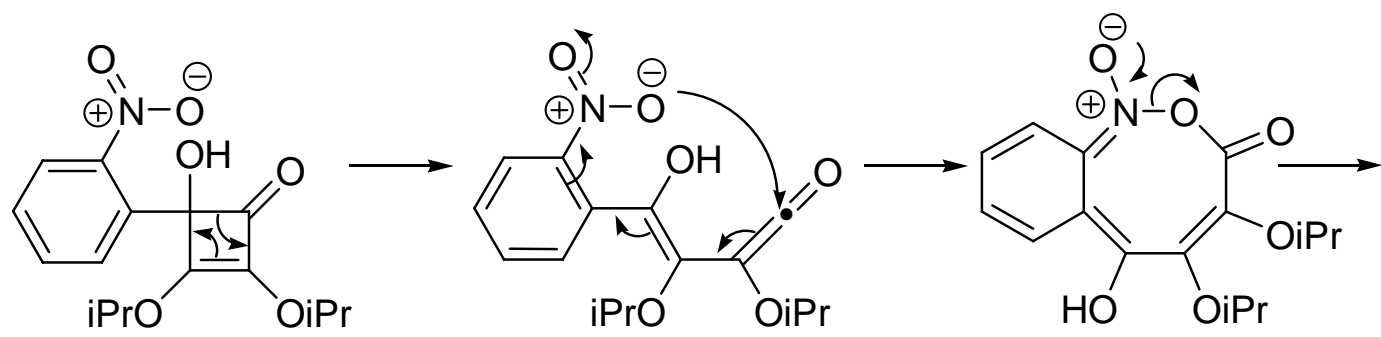

41<smiles>CC(C)OC(=O)C(O)=C(O)C(=O)C(O)=C1C=CC=CC1=N[O-]</smiles>

44<smiles>CC(C)Oc1c(O)c(O)c2ccccc2c1[N+](=O)[O-]</smiles>

47<smiles>CC(C)Oc1c(O)n([O-])c2ccccc2c1=[OH+]</smiles>

48<smiles>CC(C)Oc1c(OC(C)C)n(O)c2ccccc2c1=O</smiles>

40

To expand the scope of the halogen metal exchange protocols and to study thermolysis reactions of functional groups without nitrogens, 1,2-bromoiodobenzene was reacted with nBuLi, then diisopropyl squarate was added to form 49 (Scheme 31). ${ }^{36}$ It was then heated at 135 ${ }^{\circ} \mathrm{C}$ to afford $\mathbf{5 0}$. Initial attempts of this reaction seemed to give mixtures of the quinone and hydroquinone derivative of $\mathbf{5 0}$. Therefore the crude mixture following thermolysis was exposed to silver oxide to ensure the formation of the naphthoquinone $\mathbf{5 0}$. This method proved to be successful giving naphthoquinone $\mathbf{5 0}$ in $\mathbf{7 0 \%}$ yield. Additionally this sequence affords a 
compound $\mathbf{5 0}$ that has highly versatile for a variety of metal-catalyzed coupling reactions to provide more complex naphthoquinones.

\section{Scheme 31 BromoBenzene Addition-Thermolysis Method}<smiles>Brc1ccccc1I</smiles>

1. 1.05 eq $n-B u L i$

$\mathrm{Et}_{2} \mathrm{O} / \mathrm{THF}-110^{\circ} \mathrm{C} 30 \mathrm{~min}$

2. diisopropylsquarate

THF $-78^{\circ} \mathrm{C} 12 \mathrm{~h}$

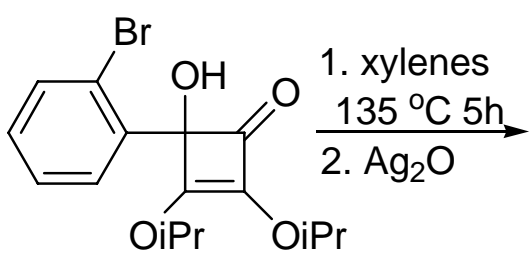

$49(88 \%)$<smiles>CC(C)OC1=C(OC(C)C)C(=O)c2c(Br)cccc2C1=O</smiles>

$50(70 \%)$

\section{Conclusion}

Nucleophiles were successfully made through ortho-lithiation and lithium halogen exchange, were added to with diisopropyl squarate to afford a variety of 4-hydroxy-4arylcyclobutenones. With respect to ortho-lithiations, the director, carbamate and methoxy, have been shown to compete for the addition site. A general route to a group of substituted1,4-naphthoquinones has been developed with the best results coming from the Bromoaryl derivative. The quinones were prepared by thermolysis followed by oxidation of 4-hydroxy-4aryl-substituted cyclobutenones to afford a variety of substituted naphthoquinones with varying success. 


\section{Chapter 2 Unsymmetrical Cyclobutendione Reactions.}

It was reported in the literature by Moore ${ }^{34}$ that rearrangements of hydroxycyclobutenones could be forced by employing TFAA in pyridine (Scheme 32) forming unsymmetrical cyclobutendiones like 53. A paper by Liebeskind ${ }^{37}$ reports that various nucleophiles can be added to unsymmetrical cyclobutendiones, like $\mathbf{5 3}$ and this can be accomplished with high regioselectivity (Scheme 33). The regioselectivity observed throughout the additions has been attributed to an electron deficiency of one the carbonyl carbons compared to the other. The electrons of methoxy group in $\mathbf{5 4}$ can be donated to one of the carbonyls and not to the other. Therefore one of the carbonyls becomes more electrophilic than the other. Lastly the Liebeskind report provides numerous examples of thermal rearrangement reactions that include aryl groups similar to 56.

\section{Scheme 32 Moore TFAA Rearrangement ${ }^{34}$}<smiles>COc1c(OC)c(=O)c1=O</smiles>

51<smiles>COC1=C(OC)C(C)(O)C1=O</smiles>

52<smiles>COc1c(C)c(=O)c1=O</smiles>

53

\section{Scheme 33 Liebeskind Aryl Addition-Thermolysis Protocol ${ }^{37}$}<smiles>COc1c(C)c(=O)c1=O</smiles>

54<smiles>COC1=C(C)C(=O)C1(O)c1ccccc1</smiles>

1. xylen air<smiles>COC1=C(C)C(=O)c2ccccc2C1=O</smiles>

As an extension of the previous studies, attention was focused on the use of unsymmetrical cyclobutendiones to obtaining aryl substituted naphthoquinones. Specifically, with combining 
aspects of both the Moore's TFAA rearrangments ${ }^{34}$ and Liebeskind regioselective additionthermolysis protocols, ${ }^{36}$ it should be possible to build molecules with a tetracyclic core structures (Scheme 34). A common intermediate $\mathbf{5 7}$ in the synthesis of the anti-cancer drug ellipticine contains a tetracyclic indoloquinone core. ${ }^{38}$ It was envisioned that a model system of the core, with a phenyl ring instead of a pyridine ring, could be constructed through the aminoquinone intermediate $\mathbf{5 9}$ previously reported to readily cyclize to the indole $\mathbf{5 8} .^{39}$ Therefore, if aryl substituted cyclobutenones such as $\mathbf{6 0}$ could be constructed utilizing the methods of Moore and Liebeskind (Scheme 32 and 33) and subjected to thermal rearrangement conditions then the core $\mathbf{5 8}$, similar to that of ellipticine, could be synthesized in a limited number of steps.

\section{Scheme 34 Ellipticine Model System}<smiles>O=C1c2cnccc2C(=O)c2c1[nH]c1ccccc21</smiles>

57<smiles>Cc1c2cnccc2c(C)c2c1[nH]c1ccccc12</smiles>

Anti-cancer drug Ellipticine<smiles>O=C1c2ccccc2C(=O)c2c1[nH]c1ccccc21</smiles>

58

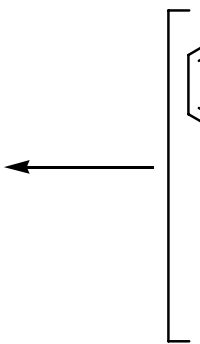

(c)

59

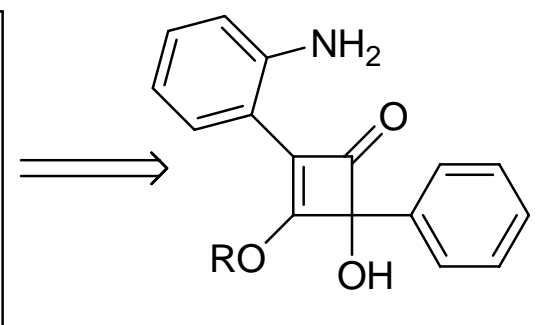

60

With the intermediate $\mathbf{6 0}$ as a target, the dianion addition reaction products $\mathbf{5}$ and $\mathbf{3 6}$ were revisited. Hydroxy cyclobutendones $\mathbf{5}$ and $\mathbf{3 6}$ were subjected to TFAA to form the desired 
unsymmetrical cyclobutendiones $\mathbf{6 1}$ and $\mathbf{6 2}$ in 75 and 76\% yields, respectively (Scheme 35).

Next they were reacted with PhLi to afford 63 and 64 in $89 \%$ and $82 \%$ yields. With the thermal rearrangement precursors available, temperatures and time of heating were varied to study their effect on the reactions. However, with both substrates $\mathbf{6 3}$ and $\mathbf{6 3}$ all reactions produced mixtures of unknown compounds that were very difficult to separate.

\section{Scheme 35 Thermal Rearrangment of 63 and 64}

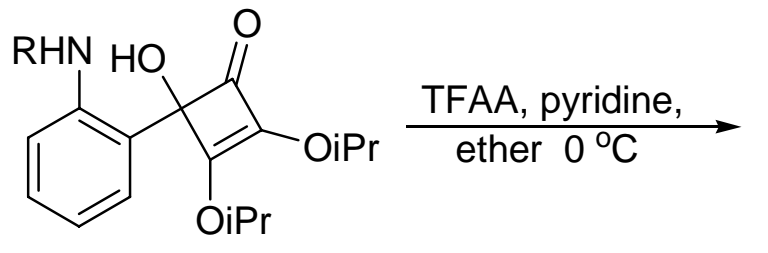<smiles>[R]Nc1ccccc1-c1c(OCC)c(=O)c1=O</smiles>

\section{$\mathrm{R}=\mathrm{Boc} 5$} R=Piv 36

$\mathrm{R}=\mathrm{Boc} 61(75 \%)$ R=Piv $62(76 \%)$<smiles>[R9]c1ccccc1C1=C(OCC)C(O)(c2ccccc2)C1=O</smiles>

$\mathrm{R}=\mathrm{Boc} 63(89 \%)$

R=Piv $64(82 \%)$

The alcohol moiety was initially thought to be responsible for the unwanted reactions and therefore, the alcohol moieties of $\mathbf{6 3}$ and $\mathbf{6 4}$, were protected as TMS ethers (Scheme 36). The $\mathrm{N}$-pivaloyl substrate $\mathbf{6 4}$ was protected with TMSCl under basic conditions to afford 65 in $66 \%$ yield. ${ }^{40}$ The carbamate $\mathbf{6 6}$ was synthesized by trapping, in situ, the alkoxide formed by the addition of PhLi to 61 by addition of TMSCI. ${ }^{41}$ 


\section{Scheme 36 Synthesis of 65 and 66}<smiles>CC(C)OC1=C(c2ccccc2N)C(=O)C1(O)c1ccccc1</smiles>

64<smiles>CC(C)Oc1c(-c2ccccc2N)c(=O)c1=O</smiles>

1. PhLi, THF, $-78^{\circ} \mathrm{C}$

2. TMSCl

61

$\underset{\mathrm{DMAP}, \mathrm{TMSCl}}{\stackrel{\mathrm{DMF}}{\longrightarrow}}$<smiles>CC(C)OC1=C(c2ccccc2N)C(=O)C1(O[Na])c1ccccc1</smiles>

$65(66 \%)$<smiles>CC(C)OC1=C(c2ccccc2N)C(=O)C1(O[Na])c1ccccc1</smiles>

$66(41 \%)$

The next step was to subject the silyl ethers to thermal rearrangements (Scheme 37). There was substantial evidence as seen by crude the ${ }^{1} \mathrm{H}$ NMR spectrum that both experiments had yielded a major product with small amounts of others in the mixture. While not the desired products, the structure of the major products 67 and 68 were elucidated by numerous NMR experiments. Its should be noted that if thermolysis was attempted in temperatures lower than the $160{ }^{\circ} \mathrm{C}$, the starting materials were recovered.

\section{Scheme 37 Synthesis of 67 and 68}<smiles>[R]Nc1ccccc1C1=C(OC(C)C)C([O-])(c2ccccc2)C1=O</smiles>

R= Piv 65

$\mathrm{R}=\mathrm{Boc} 66$<smiles>[R]N1C(=O)/C(=C(/OC(C)C)C([O+])c2ccccc2)c2ccccc21</smiles>

R= Piv $67(43 \%)$ $\mathrm{R}=\operatorname{Boc} 68(78 \%)$ 
Mechanistic explanation of the result comes from an initial retro [2+2] cycloaddition forming the ketene intermediate $\mathbf{7 0}$ (Scheme 38). It is likely that addition of the nitrogen to the ketene promoted a cyclization forming intermediate 71. Upon proton transfer and tautomerization the reaction could provide the oxindole 73.

\section{Scheme 38 Proposed Mechanism of 67 and 68}<smiles>[R]Nc1ccccc1C1=C(O)C2([O-])C(=O)C1(c1ccccc1)C2=O</smiles>

69

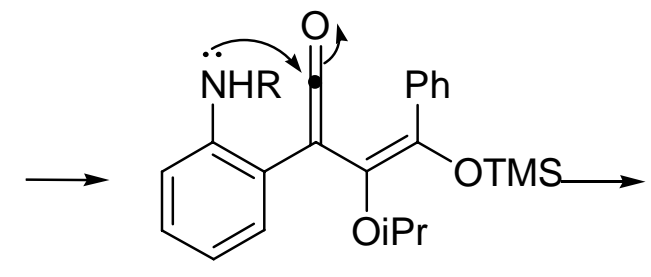

70

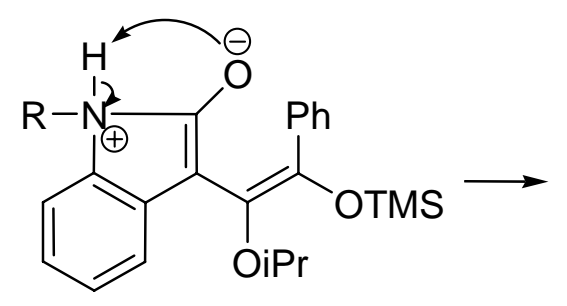

71<smiles>[R]n1c(O)c(/C(O[Na])=C(/OC)c2ccccc2)c2ccccc21</smiles>

72<smiles>[R]N1C(=O)/C(=C(/OC(C)C)C([O+])c2ccccc2)c2ccccc21</smiles>

73

Upon full characterization of $\mathbf{6 7}$ and $\mathbf{6 8}$, the reaction products from the thermal rearrangement of $\mathbf{6 4}$ were reinvestigated and determined to be derivative of the same oxindole core structure as seen in 67 and 68 (Scheme 39). For the structure 75, key signals in the ${ }^{1} \mathrm{H}$ NMR spectrum at $\delta 4.1(\mathrm{dd}, J=7.7$ and $3.0 \mathrm{~Hz}), \delta 3.8(\mathrm{dd}, J=18.3$ and $3.4,1 \mathrm{H})$, and $\delta 3.5(\mathrm{dd}, J=$ 18.3 and $7.7 \mathrm{~Hz}, 1 \mathrm{H}$ ) indicating the three diastereotopic geminal protons within the molecules were found. Similar signals were found for $\mathbf{7 4}$ and it was therefore elucidated based upon the finding in 75. 


\section{Scheme 39 Reinvestigation of Thermal Rearrangement of 64 Products}

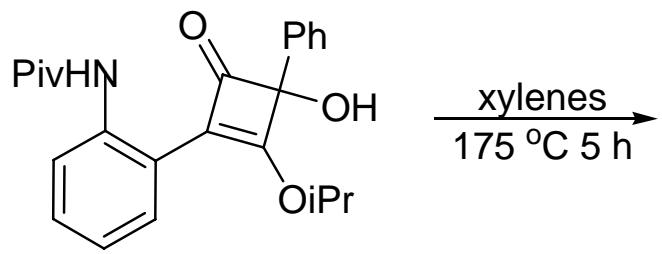

64<smiles>O=C(CC1C(=O)Nc2ccccc21)c1ccccc1</smiles>

74<smiles>O=C(CC1C(=O)Nc2ccccc21)c1ccccc1</smiles>

75<smiles>CC(C)OC(C(=O)c1ccccc1)=C1C(=O)Nc2ccccc21</smiles>

76

In an attempt to alter the reaction pathway of the thermolysis, addition of an electron rich anisole to aryl substituted cyclobutenediones became a target. Therefore hydroxycyclobutenone $\mathbf{7 7}$ was synthesized from the addition of 4-anisylmagnesium bromide to 62 (Scheme 40). The reaction proceeded well in $74 \%$ yield. The substrate was then exposed to heat. After identifying the major product as $\mathbf{7 8}$, compound $\mathbf{7 7}$ was found to undergo the reaction similarly to the previous examples. While the conditions did not promote the synthesis of naphthoquinones, the presence of an electron rich aromatic group did effect the synthesis of alkylidene oxindoles as observed from the $56 \%$ yield. In this sequence the nitrogen protecting group was also lost during the thermolysis reaction of $\mathbf{7 7}$ to $\mathbf{7 8}$. 


\section{Scheme 40 Synthesis of 78}

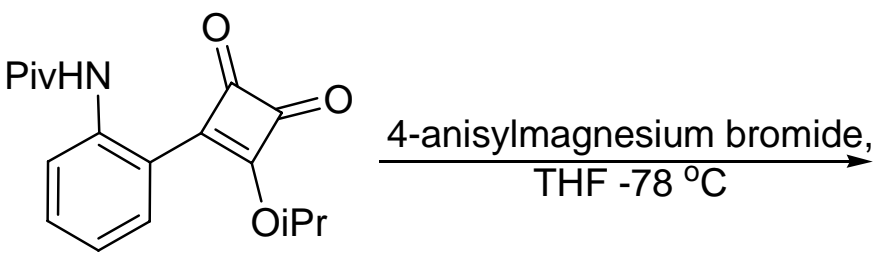

62<smiles>COc1ccc(C2(O)C(=O)C(c3ccccc3Nc3ccccc3)=C2OC(C)C)cc1</smiles>

$77(74 \%)$<smiles>COc1ccc(C(=O)C(O)=C2C(=O)Nc3ccccc32)cc1</smiles>

$78(56 \%)$

With the realization that carbamate and amide protected amines actively participate in alternate side reactions with the ketene intermediates, introduction of the amine group later in the synthesis seemed vital to the progress of the project. Estevez ${ }^{39}$ published a report where the nitrophenylnaphthoquinone $\mathbf{7 9}$ was reduced with sodium borohydride to form aminonaphthoquinone intermediate 59 that readily cyclized to form the indolonaphthoquinones 58 (Scheme 41).

\section{Scheme 41 Revised Methodology to 58}

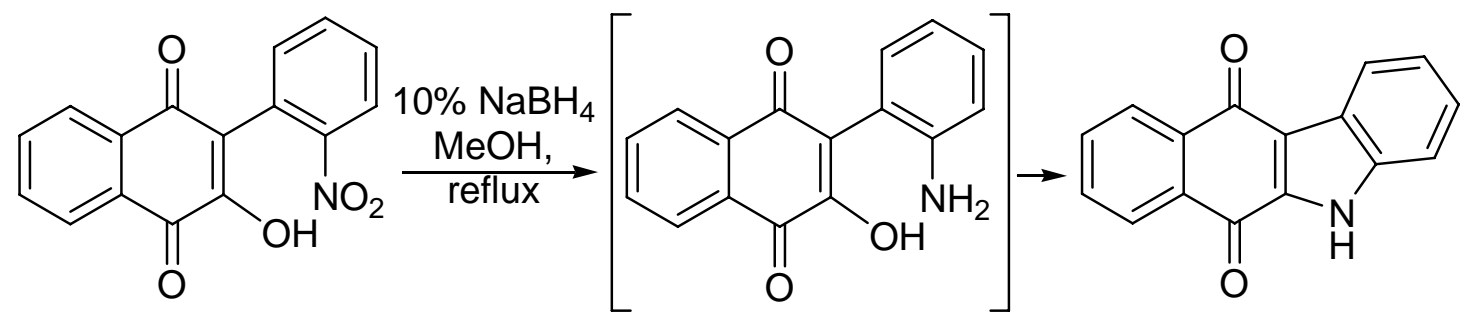
79

With a nitro substituted target core in mind, the synthesis of $\mathbf{7 9}$ began with iodonitrobenzene. Formation of the intermediate alcohol $\mathbf{5 9}$ was accomplished easily with the formation of the nitroarylmagnesium chloride reported by Knochel. ${ }^{35}$ Similar to the report, 2- 
iodonitrobenzene was subjected to $\mathrm{PhMgCl}$ at $-40{ }^{\circ} \mathrm{C}$. Then diisopropyl squarate was added to afford 80 in $72 \%$ yield (Scheme 42). The next step was attempted with and without further purification of the intermediate hydroxycyclobutenone $\mathbf{8 0}$ before treating it with TFAA. The rearrangement readily provided the desired cyclobutendione 81 in $95 \%$ yield or $68 \%$ ( 2 steps from iodonitrobenzene) for the unpurified sequence.

\section{Scheme 42 Synethsis of 81}<smiles>O=[N+]([O-])c1ccccc1I</smiles>

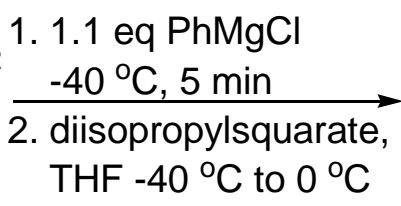
THF $-40{ }^{\circ} \mathrm{C}$ to $0^{\circ} \mathrm{C}$

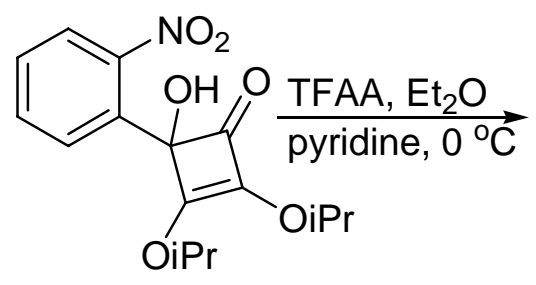<smiles>CCCOc1c(-c2ccccc2[N+](=O)[O-])c(=O)c1=O</smiles>

$80(72 \%)$
81 (95\% or $68 \% 2$ steps)

With the desired nitrosubstituted cyclobutendione in hand, a reaction protocol for the addition of phenyl nucleophiles as well as thermolysis was explored. Phenylmagnesium chloride proved to be a good source for an aromatic nucleophile whereby it was added to the nitroaryl cyclobutendione $\mathbf{8 1}$ to give the desired hydroxycyclobutenone $\mathbf{8 2}$ (Scheme 43 ) as seen by crude ${ }^{1} \mathrm{H}$ NMR spectrum. However, all attempts to purify the compound resulted in unwanted reactions on silica gel. Therefore crude $\mathbf{8 2}$ was thermolysized without purification. It was determined that the reaction did not proceed as expected. It should be noted that the reaction was also attempted in the presence of proton sponge and the results were unchanged. Instead of performing the desired cyclization to the naphthoquinone, the reaction yielded a mixture of compounds that could not be characterized. 


\section{Scheme 43 Thermal Rearrangment of 82}

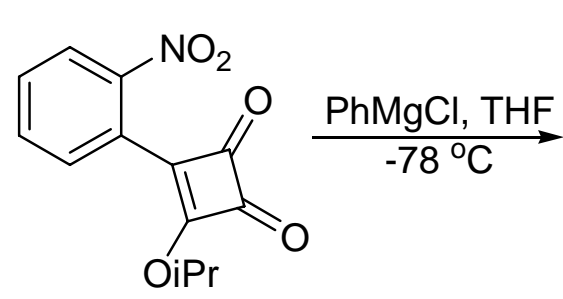

81

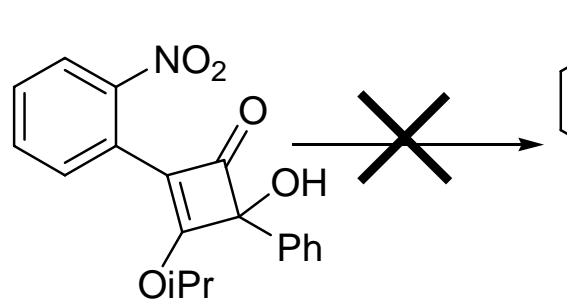

$82(98 \%)$<smiles>CC(C)OC1=C(c2ccccc2[N+](=O)[O-])C(=O)c2ccccc2C1=O</smiles>

83

In an attempt to remove the possibility of unwanted reactions of the alcohol in hydroxycyclobutenone $\mathbf{8 2}$, the aryl addition sequence was repeated, but the alcohol was trapped as the acetyl ester $\mathbf{8 4}$ using acetic anhydride (Scheme 44). The crude acetyl ester $\mathbf{8 4}$ was subjected to thermolysis and the reaction gave one product. Correlation NMR experiments of $\mathbf{8 5}$ were performed and the structure was elucidated to be the benzisoxazole $\mathbf{8 5}$.

\section{Scheme 44 Thermal Rearrangment of 84}

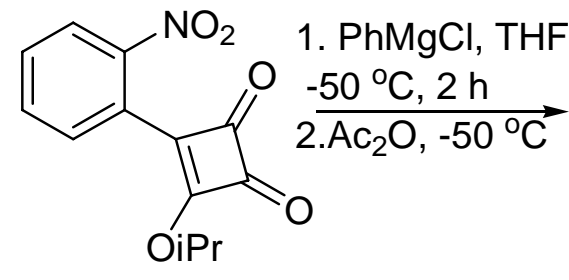

81<smiles>O=C([O-])OC1(c2ccccc2)C(=O)C(c2ccccc2[N+](=O)[O-])=C1[O-]</smiles>

84<smiles>COC(=C(OC(C)C)c1onc2ccccc12)c1ccccc1</smiles>

$85(50 \%)$

A mechanistic explanation of the reaction is proposed as proceeding via an initial retro [2+2] cycloaddition to form the ketene intermediate $\mathbf{8 6}$ (Scheme 45). Nucleophilic addition of one of the nitro oxygens to the ketene would induce a ring closure to form the intermediate $\mathbf{8 7}$. After a ring opening of $\mathbf{8 7}$, resonance forms $\mathbf{8 8}$ and $\mathbf{8 9}$ can form. Then a second ring closure by nucleophilic attack of the nitroso group forms intermediate $\mathbf{9 0}$. Finally, decarboxylation forms the benzoisoxazole 85 . 


\section{Scheme 45 Proposed Mechanism to 50}<smiles>CC(=O)OC1=C(c2ccccc2[N+](=O)[O-])C(=O)C1(OC(C)=O)c1ccccc1</smiles><smiles></smiles>

87<smiles>CC(=O)O/C(=C(\OC(C)C)C(C(=O)O)=C1C=CC=CC1=[N+]=O)c1ccccc1</smiles>

88

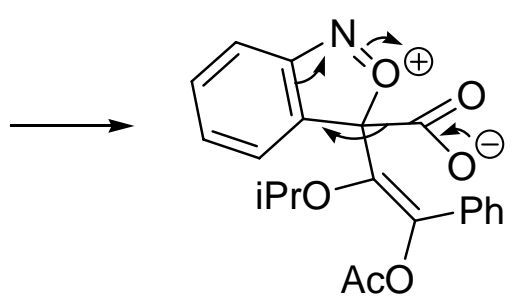

90<smiles>CC(=O)O/C(=C(/OC(C)C)c1ccccc1)c1ccccc1</smiles>

85

With some questions unanswered about the thermal rearrangements, it seemed interesting to perform the sequence with hydroxyl- and methoxy-substituted derivatives. 2-Bromophenol and 2-bromoanisole were subjected to lithium-halogen exchange ${ }^{42}$ followed by addition to diisopropyl squarate (Scheme 46). In the case of the hydroxy derivative, the expected product 91 was not observed. Instead, 92 was observed as the major product. A mechanistic reason for this product is currently unknown but it was assumed that the additional isopropoxy group might have been added from and additional molecule of diisopropylsquarate. In addition to the side product formed during the addition to squarate the compounds were very difficult to visualize on TLC, even with the aid of a variety of stains. In the 2-bromoanisole sequence the 
reaction proceeded as expected to afford 94 in $79 \%$ yield. It is noteworthy that only a small amount of the isopropyl addition was observed product 95.

\section{Scheme 46 Methoxy and Hydroxy Derivatives}<smiles>[R]Oc1ccccc1Br</smiles>

\section{1-2 eq n-BuLi \\ $\mathrm{Et}_{2} \mathrm{O}-10^{\circ} \mathrm{C} 3 \mathrm{~h}$ \\ 2. diisopropylsquarate, THF $-78{ }^{\circ} \mathrm{C} 5 \mathrm{~h}$}
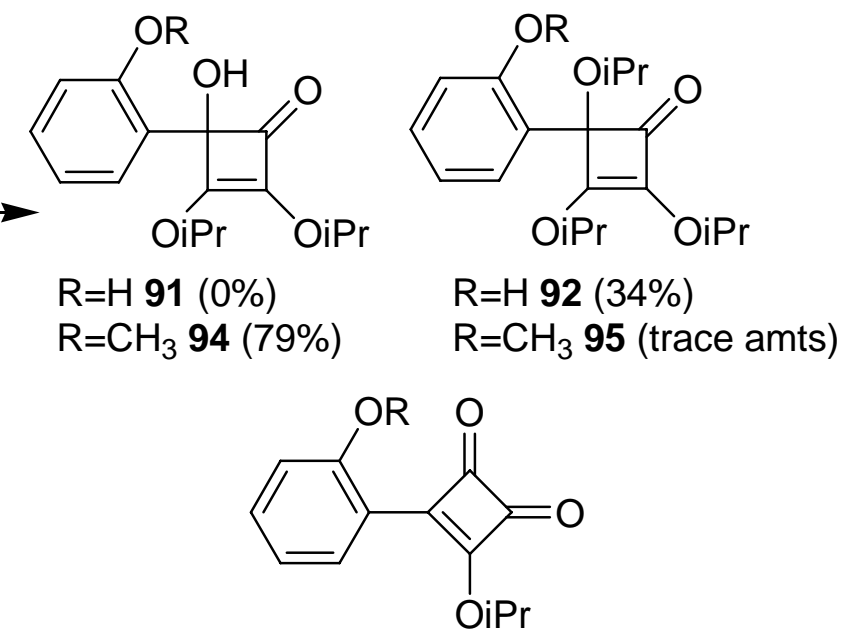

$\mathrm{R}=\mathrm{H} 93(3 \%)$

$\mathrm{R}=\mathrm{CH}_{3} 96(0 \%)$

Because of the issues associated with the phenol sequence, formation of the desired $\mathbf{9 3}$ was performed as a one pot sequence starting from 2-bromophenol (Scheme 47). 2-Bromophenol was transmetallated and added to squarate followed by TFAA rearrangement to afford 93 in $48 \%$ yield over the three steps. With the anisole derivative 94 available, it reacted with TFAA to form 96 in 79\% yield. 


\section{Scheme 47 Synthesis of 93 and 96}<smiles>Oc1ccccc1Br</smiles>

1. 2 eq $n-B u L i$ $\mathrm{Et}_{2} \mathrm{O}-10^{\circ} \mathrm{C} 3 \mathrm{~h}$

2. diisopropylsquarate, THF $-78{ }^{\circ} \mathrm{C} 5 \mathrm{~h}$

3. TFAA<smiles>CC(C)Oc1c(-c2ccccc2O)c(=O)c1=O</smiles>

$93(48 \%)$

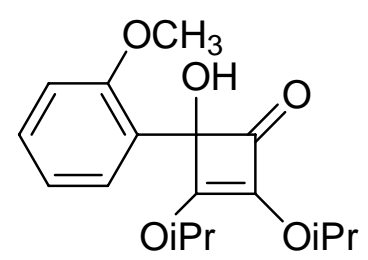

94
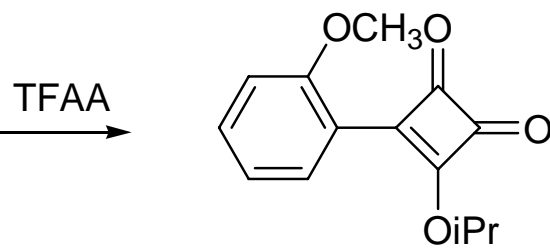

$96(79 \%)$

After obtaining 93 and 96, they were exposed to PhLi (Scheme 48). Each of the reactions proceeded well, obtaining the desired compounds 97 and 99 in $66 \%$ and $64 \%$ respectively. Then they were subjected to thermal rearrangements at $150{ }^{\circ} \mathrm{C}$ in xylenes. The phenol derivative 97 produced an unknown mixture of compounds, but the anisole derivative 99 afforded the desired naphthoquinone 100 with a high yield of $78 \%$. It is again suspected that the hydroxy group on $\mathbf{9 9}$ participated in unwanted reactions and therefore thermal rearrangement of $\mathbf{9 9}$ is not a reliable method of synthesis of hydroxyaryl naphthoquninones. Thermal rearrangement of the methoxy derivative 99 proceeded very successfully in $78 \%$ yield. It is to be noted that if the free hydroxyl compound became a target molecule compound 100 could be easily converted to 98 if the through demethylation condtions with $\mathrm{BBr}_{3}$. 


\section{Scheme 48 Synthesis of 100}<smiles>[R]Oc1ccccc1-c1c(OC(C)C)c(=O)c1=O</smiles>

$\mathrm{R}=\mathrm{H} 93$

$\mathrm{R}=\mathrm{CH}_{3} 96$<smiles>[R]Oc1ccccc1C1=C(O)C(O)(c2ccccc2)C1=O</smiles>

$\mathrm{R}=\mathrm{H} 97(66 \%)$

$\mathrm{R}=\mathrm{CH}_{3} 99(64 \%)$<smiles>[R]Oc1ccccc1C1=C(OC(C)C)C(=O)c2ccccc2C1=O</smiles>

$\mathrm{R}=\mathrm{H} 98$

$\mathrm{R}=\mathrm{CH}_{3} 100(78 \%)$

\section{Conclusion}

From this set of experiments it can be concluded that with the functional groups on the aryl substituents of these unsymmetrical cyclobutendiones participate actively in the reaction forming various products most of which are not naphthoquinones. With that in mind, formation of naphthoquinones by this method can only be executed with non-nucleophilic substituted aryl groups. Conversely this method is effective at the synthesis of oxindoles and benzisoxazoles and further development of the method for their synthesis is an area for experimentation. 


\section{Chapter 3. Alternate Sequence the Benzocarbazolequinone Core.}

After learning how susceptible the ketene intermediate during thermal rearrangements is susceptible to nucleophilic attack, a plan to introduce the nitrogen into the system after the thermolysis step was necessary. The focus shifted to a final cyclization of the tetracyclic ring system through an $\mathrm{N}$-arylation coupling methods (Scheme 49). With numerous protocols for the aminations of arylhalides with amines utilizing both palladium and copper catalysts available, it was envisioned that the amine and aryl halide of 101 could be coupled to form the indolonaphthoquinone 58. It was also proposed that the amine could be derived late in the synthesis from the amination of an ether intermediate similar to $\mathbf{1 0 2 .}$

\section{Scheme 49 Alternate Route to 58}<smiles>C=CC=CC=C</smiles>

58<smiles>[X]c1ccccc1C1=C(N)C(=O)c2ccccc2C1=O</smiles>

101<smiles>[R]OC1=C(c2ccccc2[X])C(=O)c2ccccc2C1=O</smiles>

102

The execution of the method began with a reported metal-halogen exchange protocol $^{36}$ using 1,2-dibromo benzene and $\mathrm{n}$-BuLi at $-110^{\circ} \mathrm{C}$ (Scheme 50). The paper reports that with a constant temperature of $-110^{\circ} \mathrm{C}$, the reaction forms the lithium bromide exchange intermediate 103. However, heating the reaction to $-90{ }^{\circ} \mathrm{C}$ gives decomposition products derived from benzyne formation. 


\section{Scheme 50 Lithium Halogen Exchange of 1,2-Dibromobenzene}<smiles>CCOc1ccc(Br)c(Br)c1</smiles>

103

With the intention of using the reported method to add an aryl halide to squarate, iodobromobenzene was reacted with $\mathrm{n}$-BuLi in the cosolvent system of $\mathrm{THF}-\mathrm{Et}_{2} \mathrm{O}$ at $-110{ }^{\circ} \mathrm{C}$ (Scheme 51, Method A). After stirring for $30 \mathrm{~min}$, diisopropylsquarate in THF was added and stirred for $5 \mathrm{~h}$ to give $\mathbf{4 9}$ in $88 \%$ yield. An alternate method was employed for the synthesis of the halogen metal exchange using disopropyl magnesium. In this method, diisopropyl magnesium was prepared in situ by dissolving isopropyl magnesium chloride in dioxane. ${ }^{43}$ From there the iodobromobenzene was subjected to the freshly prepared diisopropyl magnesium at reduced temperatures of $-40{ }^{\circ} \mathrm{C}$, then exposed to diisopropyl squarate to provide 49 in $47 \%$ (Scheme 51, Method B). From the comparison of the two reports it is easy to note that while method A gave a better yield, however, it is very sensitive in comparison to method $B$. When there was slight increase in temperatures, method A provided little to no 49. Therefore method $B$ is a viable method when $-110^{\circ} \mathrm{C}$ cannot be ensured since it is more robust. From there $\mathbf{4 9}$ was treated with the TFAA to afford the bromoarylcyclobutendione 104 in 99\% yields. 


\section{Scheme 51 Synthesis of 104}

Method A:

1. 1.05 eq nBuLi, THF/Et $2 \mathrm{O}$

$$
-110^{\circ} \mathrm{C}
$$

2. Diisopropylsquarate, $\mathrm{THF}$<smiles>Brc1ccccc1I</smiles>

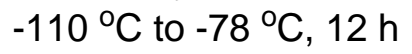

$(88 \%)$

Method B

1. 0.55 eq Diisopropyl magnesium,

THF, $-40^{\circ} \mathrm{C}$

2. Diisopropylsquarate, THF $-40{ }^{\circ} \mathrm{C} 12 \mathrm{~h}$

$(47 \%)$<smiles>CC(C)OC1=C(OC(C)C)C(O)(c2ccccc2Br)C1=O</smiles>

49

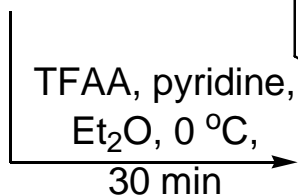<smiles>CC(C)Oc1c(-c2ccccc2Br)c(=O)c1=O</smiles>

$104(99 \%)$

Phenylmagnesium chloride was added to 104 to afford 105 in 82\% yield (Scheme 52).

Hydroxycyclobutenone 105 was then heated in toluene at $125^{\circ} \mathrm{C}$ for $30 \mathrm{~min}$. To much delight, the reaction afforded the desired naphthoquinone 106 in $98 \%$ yield.

\section{Scheme 52 Synthesis of 106}

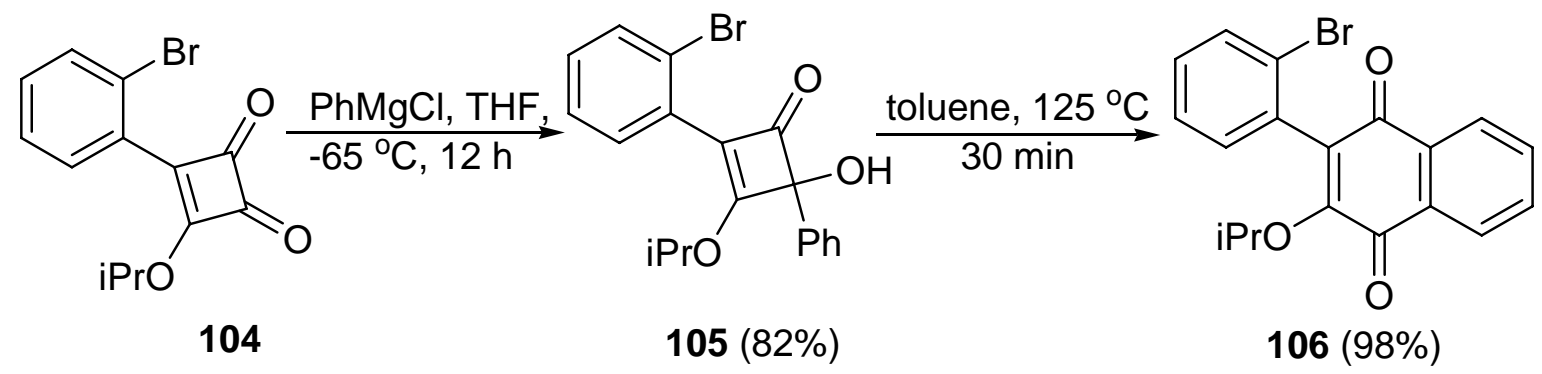

With two steps of the proposed methodology left to complete the synthesis of the indolonaphoquinone core, attention was turned to the amination of 106. In 2005 it was reported $^{44}$ that nucleophilic displacement of 2-methoxylapachol 107 with $30 \%$ ammonium hydroxide solution yielded the amino derivative 108 in $45 \%$ yield (Scheme 53 ). 


\section{Scheme 53 Amination of 2-Methoxylapachol.}<smiles>COC1=C(CC=C(C)C)C(=O)c2ccccc2C1=O</smiles>

107

\section{$\frac{30 \% \mathrm{NH}_{4} \mathrm{OH}_{4}}{\mathrm{MeOH}, \mathrm{rt} 24 \mathrm{hr}}$}<smiles>CC(C)=CCC1=C(N)C(=O)c2ccccc2C1=O</smiles>

$108(45 \%)$

From this work it was envisioned that the isopropyl group of $\mathbf{1 0 6}$ could be replaced with an amine group in a similar manner. Therefore, the naphthoquinone 106 was exposed to 30\% ammonium hydroxide in $\mathrm{MeOH}$ to afford the desired amino derivative 109 in $61 \%$ yield (Scheme 54). The compound's solubility proved to be a challenge but best results came from the reactions with a minimum amount of methanol.

\section{Scheme 54 Synthesis of 109}<smiles>CC(C)OC1=C(c2ccccc2Br)C(=O)c2ccccc2C1=O</smiles>

106

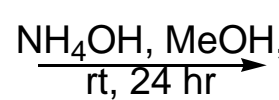<smiles>NC1=C(c2ccccc2Br)C(=O)c2ccccc2C1=O</smiles>

$109(61 \%)$

With only the final ring closure left in the synthesis of the indolonaphthoquinone core, protocols for $\mathrm{N}$-arylation were explored. Many aromatic coupling have been reported and a variety of protocols are available. The work of Buchwald was initially chosen which reports in the literature of Pd/BINAP catalyzed aminations of aryl halides(Scheme 55$).{ }^{45}$ The report cites various substrates reacting at reaction times between $16-20 \mathrm{~h}$ to afford a variety of aminated products with a variety of substituents in high yield. Because of the flexibility and the extensive versatility of the method it was chosen as a first attempt. However in two trials at temperature 
of $90{ }^{\circ} \mathrm{C}$ and $120^{\circ} \mathrm{C}$, the reaction returned starting material as was seen in the crude ${ }^{1} \mathrm{H} N M R$ spectrum and thus the method was abandoned (Table 6).

\section{Scheme 55 Standard Buchwald Amination Conditions}

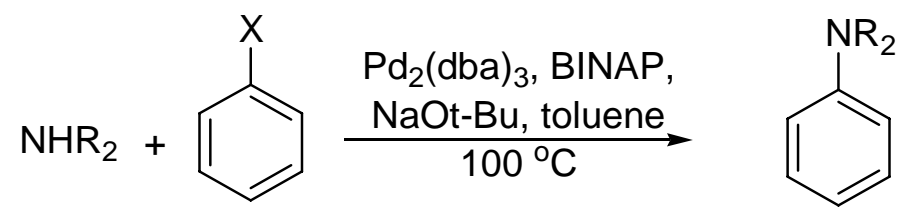

The next method selected was from a paper that reported a highly efficient palladacycle precatalyst that is air, moisture, and thermally stable (Scheme 56). ${ }^{46}$ The report also establishes the use of the catalyst with a variety of aryl chlorides and amines to afford the coupled products. However, this method was unsuccessful on the precursor 109 because when it was exposed to the report reaction conditions, it also resulted in recovery of only starting material (Table 6).

\section{Scheme 56 Expansion of Buchwald's Methodlogy}

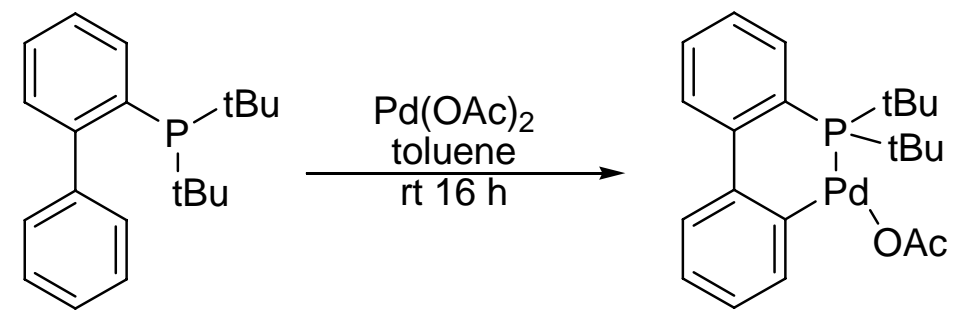<smiles>[R2]Nc1ccccc1</smiles>

With the previous two failures, palladium catalyzed reactions were abandoned. With copper also a possible catalyst, a report was selected where aryl halides and amines were exposed to $\mathrm{Cul}, \mathrm{K}_{2} \mathrm{CO}_{3}$, and pipecolinic acid, in DMF (Scheme 57). ${ }^{47}$ When compound 109 was 
reacted under these copper catalyzed conditions, the reaction afforded the naphthoquinone

110 in a 59\% yield (Table 6).

Scheme 57 Copper Catalyzed N-Arylation

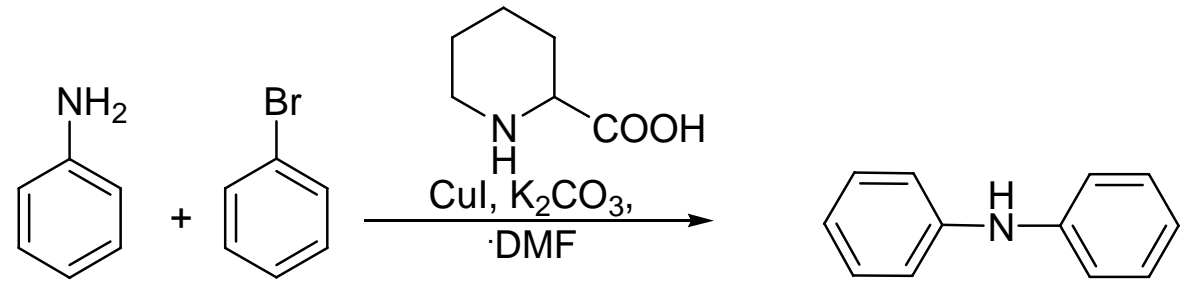

Table 6 Trials for the Synthesis of $\mathbf{1 1 0}$<smiles>Cc1ccc2c3c([nH]c2c1)C(=O)c1ccccc1C3=O</smiles>

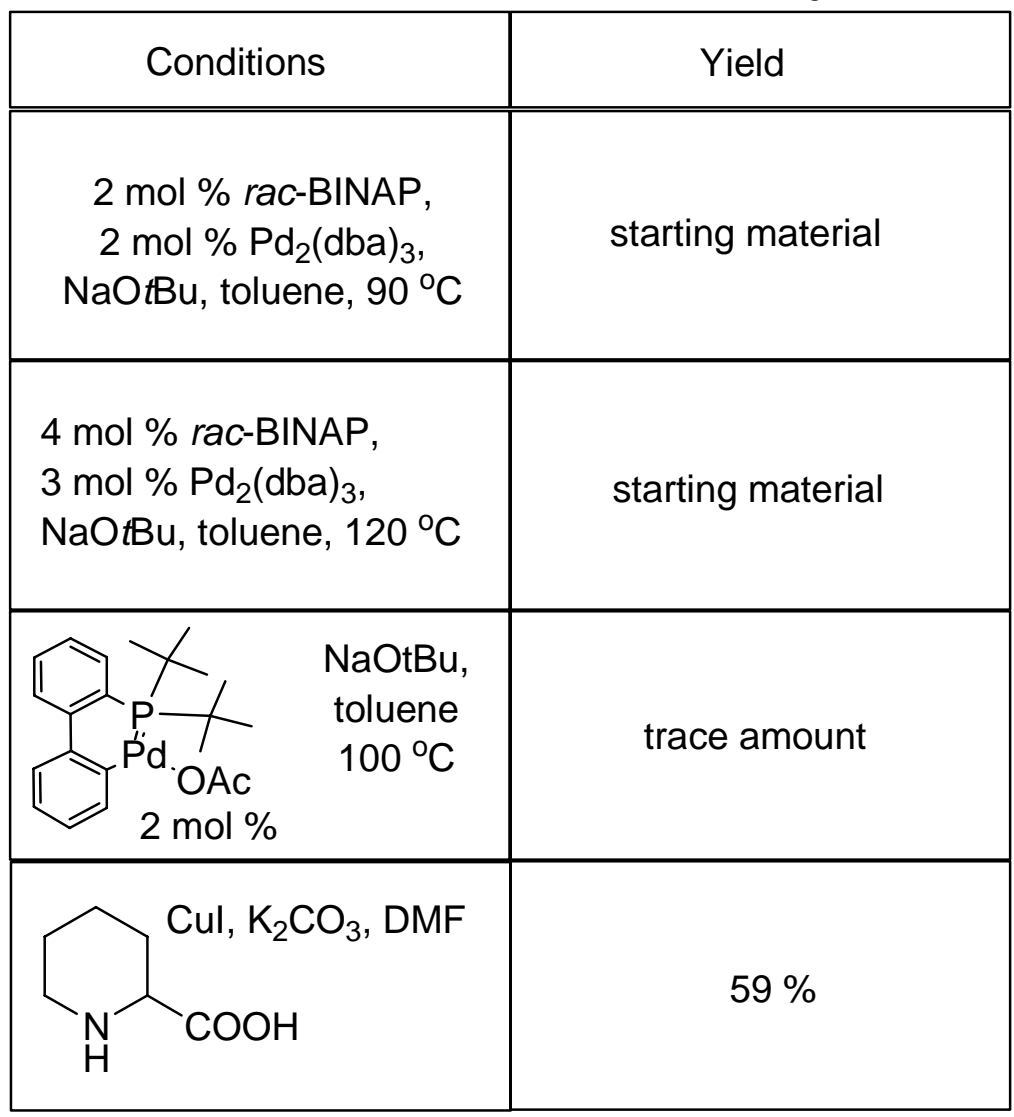


With a successful protocol for the formation of the indolonaphthoquinone core, expansion of the method to include other functionalities became increasingly interesting. The next nucleophile added to the bromoarylcyclobutendione 104 was 4-anisylmagnesium bromide (Scheme 58). The addition proceeded well giving $\mathbf{1 1 1}$ in $81 \%$ yield. The formed hydroxycyclobutenone was exposed to the thermal rearrangement conditions and the reaction proceeded to completion within $2 \mathrm{~h}$. The naphthoquinone 112 was then subjected to nucleophilic displacement conditions to afford the amine $\mathbf{1 1 3}$ in 58\% yield. It should be noted that the solubility issues from the model system continued to be problematic, but the use of a limited amount of methanol and longer reaction times seemed to be most effective. With the indole ring closure as the sole remaining step, amine 113 was subject to the same coppercatalyzed N-arylation as previously reported to produce the desired methoxy derivative 114 in $50 \%$ yield. 


\section{Scheme 58 Synthesis of 114}

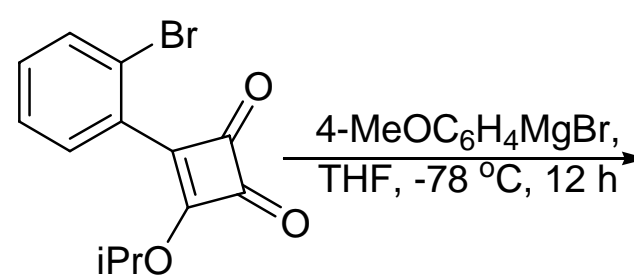

104<smiles>COc1ccc(C2(O)C(=O)C(c3ccccc3Br)=C2OC(C)C)cc1</smiles><smiles>COc1ccc2c(c1)C(=O)C(c1ccccc1Br)=C(OC(C)C)C2=O</smiles>

112 (Quant)<smiles>COc1ccc2c(c1)C(=O)C(c1ccccc1Br)=C(N)C2=O</smiles>

113 (58\%)<smiles>CC(C)(C)OC(=O)C1CC2CCC1CC2C(=O)O</smiles><smiles>COc1ccc2c(c1)C(=O)c1c([nH]c3ccccc13)C2=O</smiles>

With success in two systems, increased sterics during the thermal rearrangement became another area to vary in the system. Therefore 2-methoxyphenylmagnesium bromide was added to the bromoarylcyclobutendione 104 (Scheme 59). The reaction sequence proceeded in a similar manner as that of the previously reported substrate 105 with the exception of the thermal rearrangement reaction which provided the desired 116 in 63\% yield. Perhaps the added sterics impacted the outcome of the cyclization. Overall the sequence of reactions again afforded the desired $\mathbf{1 1 8}$ in limited number of steps. 


\section{Scheme 59 Synthesis of 118}

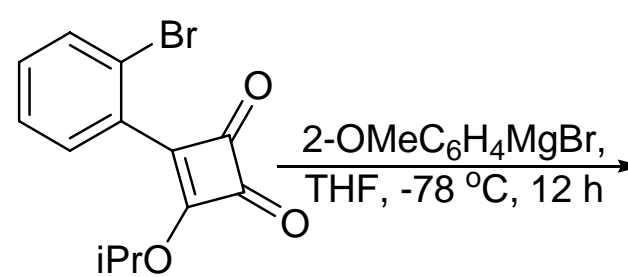

104<smiles>COc1ccccc1C1(O)C(=O)C(c2ccccc2Br)=C1OCC(=O)O</smiles><smiles>COC(=O)OC</smiles><smiles>COc1cccc2c1C(=O)C(N)=C(c1ccccc1Br)C2=O</smiles>

$117(47 \%)$

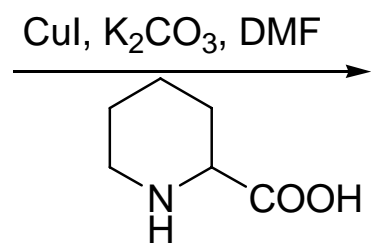<smiles>COc1cccc2c1C(=O)c1[nH]c3ccccc3c1C2=O</smiles>

$118(43 \%)$

For a final example of the use of the method that has been developed, the cyclization to a furan ring instead of the reported indole ring was explored. It was reported in the literature ${ }^{48}$ that 119 can be coupled under Ullmann coupling conditions to afford the benzo[b]naphtha[2,3d] furan-6,11-dione 120 (Scheme 60).

\section{Scheme 60 Reported Furan Coupling Reaction}<smiles>O=C1C(O)=C(c2ccccc2Br)C(=O)c2ccccc21</smiles>

119<smiles>CC(=O)C(=O)OC(=O)C(C)C</smiles><smiles>O=C1c2ccccc2C(=O)c2c1oc1ccccc21</smiles>

120 
Also reported in the literature is the demethylation of $\mathbf{1 2 1}$ in the presence of $\mathrm{BBr}_{3}$ at cold temperatures (Scheme 61). ${ }^{49}$ The reaction proceed to form the naphthazarin 122 in quantitative yield.

\section{Scheme 61 Demethylation Conditions}<smiles>COc1c(C)c(OC)c2c(OC)c(C)c(OC)c(OC)c2c1OC</smiles>

121<smiles>CC1=C(O)C(=O)c2c(O)c(O)c(C)c(O)c2C1=O</smiles>

122 (Quant)

Compound 106 was synthesized as previously reported, then demethylation conditions were applied to 106 where it was reacted with $\mathrm{BBr}_{3}$ to applied to 106 it afforded the alcohol 119 in a quantitative yield. From this experiment it is concluded that the established methodology can be applied as a new method of synthesis of benzo[b]naphtha[2,3-d] furan-6,11-diones in addition to the method to form benzocarbazolequinones. Another impressive point about the synthesisof 119, is that the method presented accomplishes the synthesis in 5 steps in contrast to the reported synthesis in 7 steps.

\section{Scheme 62 Synthesis of 119}

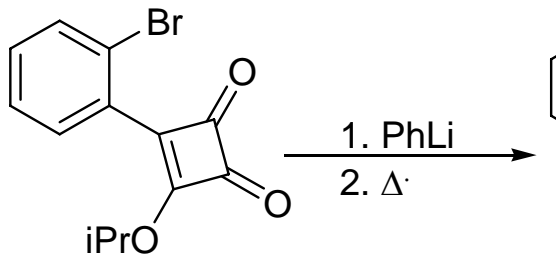

104<smiles>CC(C)OC1=C(c2ccccc2Br)C(=O)c2ccccc2C1=O</smiles>

106<smiles>O=C1C(O)=C(c2cc(C=C(Br)Br)ccc2Br)C(=O)c2ccccc21</smiles>

119 (Quant) 


\section{Conclusion}

A new methodology for the synthesis of benzocarbazolequinones and benzofurannaphthoquinones has been developed. The synthesis is accomplished in six steps, some of which can proceed without purification of the crude intermediates. Variations of functional groups on the naphthoquinone rings should be explored for further versatility. It is also noteworthy that the method is projected to be adapted to form carbazolquinones when alkyne nucleophiles are implemented instead of aryl nucleophiles. 


\section{Part 3}

\section{Experimental Section}

\section{General Procedures}

All NMR spectra were determined in $\mathrm{CDCl}_{3}$ at $270 \mathrm{MHz}\left({ }^{1} \mathrm{H} \mathrm{NMR}\right)$ and $67.5 \mathrm{MHZ}\left({ }^{13} \mathrm{C} \mathrm{NMR}\right)$ or at $600 \mathrm{MHz}\left({ }^{1} \mathrm{H} \mathrm{NMR}\right)$ and $150 \mathrm{MHz}\left({ }^{13} \mathrm{C} \mathrm{NMR}\right)$, respectively. The chemical shifts are expressed in $\delta$ values relative to $(\mathrm{Me}){ }_{4} \mathrm{Si}\left(0.00 \mathrm{ppm},{ }^{1} \mathrm{H}\right.$ and $\left.{ }^{13} \mathrm{C}\right)$ or $\mathrm{CDCl}_{3}\left(77.0 \mathrm{ppm},{ }^{13} \mathrm{C}\right)$ internal standards. ${ }^{1} \mathrm{H}-{ }^{1} \mathrm{H}$ coupling constants are reported as measured from spectra; thus a slight difference between $J_{a, b}$ and $J_{b, a}$ is usually obtained. Results of Attached Proton Test- ${ }^{13} \mathrm{C}$ NMR experiments are shown in parenthesis where, relative to the $\mathrm{CDCl}_{3},(-)$ denotes $\mathrm{CH}_{3}$ or $\mathrm{CH}$ and (+) denotes $\mathrm{CH}_{2}$ or $\mathrm{C}$. Tetrahydrofuran (THF) was distilled from sodium benzophenone ketyl prior to use. Ether, toluene, and triethyl amine were passed through a steel column filled with activated alumina ( 8 X 14 mesh, Sorbent Technology) using argon pressure. Hexanes, xylenes, toluene and ethyl acetate were distilled from calcium hydride. Chemicals prepared according to literature procedures have been footnoted first time used; all other reagents were obtained from commercial sources and used as received. All reactions were performed under nitrogen atmosphere with oven dried $\left(120^{\circ} \mathrm{C}\right)$ glassware unless stated otherwise. Solvents were removed from reaction mixtures and products on rotary evaporator at water aspirator pressure unless stated otherwise. Cooling bath temperatures were controlled with the aid of a Polyscience cryocooler. Column Chromotography was performing using silica gel with a particle size of $40-63 \mu \mathrm{m}$. All Infared Spectra were obtained neat on a Perkin Elmer Spectrum One FT-IR Spectrometer. Melting points were determined on a MelTemp apparatus and are uncorrected. 
High Resolution Mass Spectra were obtained using a ThermoElectron Corporation LTQFT Ultra. Electrospray lonization (ESI) was used as the ionization method and ions were detected in an ion cyclotron resonance (ICR) cell. All HRMS were completed by Brent Reschke from the Dr. Aaron Timperman Laboratories, C. Eugene Bennett Department of Chemistry.

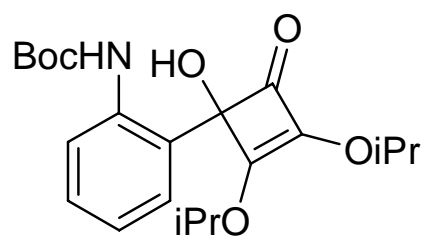

tert-Butyl 2-(1-hydroxy-2,3-diisopropoxy-4-oxocyclobut-2-enyl)phenylcarbamate (5) At -78 ${ }^{\circ} \mathrm{C}$ under $\mathrm{N}_{2}$ atmosphere, t-BuLi (1.1 mL, $1.76 \mathrm{mmol}, 1.6 \mathrm{M}$ in pentane) was added to the mixture of tert-Butyl phenylcarbamate $(55 \mathrm{mg}, 0.28 \mathrm{mmol})$ in THF $(1.0 \mathrm{~mL})$ then warmed to $-20{ }^{\circ} \mathrm{C}$. After stirring for $4 \mathrm{~h}$, squarate $(90 \mathrm{mg}, 0.43 \mathrm{mmol})$ in THF $(2 \mathrm{~mL})$ was added via cannula. After stirring for 30 min, the reaction was quenched at $-20{ }^{\circ} \mathrm{C}$ with $10 \% \mathrm{NH}_{4} \mathrm{Cl}$ in $\mathrm{H}_{2} \mathrm{O}$ and extracted with ether. The combined organic portions were dried over $\mathrm{MgSO}_{4}$, filtered then solvents were removed under reduced pressure. The residue was purified via chromatography (hexane:EtOAc, 9:1) to afford 5 (81 mg, $0.21 \mathrm{mmol}, 73 \%)$ as a colorless oil. ${ }^{1} \mathrm{H} \mathrm{NMR}(270 \mathrm{MHz}) \delta$ $8.66(\mathrm{br} \mathrm{s}, 1 \mathrm{H}), 7.98(\mathrm{~d}, J=7.9 \mathrm{~Hz}, 1 \mathrm{H}), 7.43(\mathrm{dd}, J=7.7$ and $1.5 \mathrm{~Hz}, 1 \mathrm{H}), 7.29(\mathrm{t}, J=6.9,1 \mathrm{H}), 6.98$ (t, $J=7.7 \mathrm{~Hz}, 1 \mathrm{H}), 5.00$ (sept, $J=6.2 \mathrm{~Hz}, 1 \mathrm{H}), 4.92(\operatorname{sept}, J=6.2 \mathrm{~Hz}, 1 \mathrm{H}), 1.54(\mathrm{~s}, 9 \mathrm{H}), 1.47(\mathrm{~d}, J=$ $6.2 \mathrm{~Hz}, 6 \mathrm{H}), 1.32(\mathrm{~d}, J=6.2 \mathrm{~Hz}, 3 \mathrm{H}), 1.24(\mathrm{~d}, J=6.2 \mathrm{~Hz}, 3 \mathrm{H}) ;{ }^{13} \mathrm{C} N M R(67.5 \mathrm{MHz}) \delta 184.1(+)$, $165.7(+), 153.6(+), 137.3(+), 132.0(+), 129.5(-), 127.6(+), 126.5(-), 122.9(-), 122.1(-), 86.7$ $(+), 80.0(+), 77.8(-), 74.0(+), 28.4(-), 22.8(-), 22.7(-), 22.6(-), 22.2(-)$; IR (neat) 3477, 3338, $2972,1781,1728,1588,1343,1163 \mathrm{~cm}^{-1}$. 
<smiles>CC(C)OC1=C(OC(C)C)C(=O)c2c(NC(=O)OCc3ccccc3)cccc2C1=O</smiles>

tert-Butyl 1,4-dihydro-2,3-diisopropoxy-1,4-dioxonaphthalen-5-ylcarbamate (6) Compound 5 (52 $\mathrm{mg}, 0.13 \mathrm{mmol}$ ) dissolved in xylenes $(2 \mathrm{~mL}$ ) was transferred to a pressure tube and then the reaction vessel was sealed and submerged into a sand bath at $170{ }^{\circ} \mathrm{C}$. After heating for $3 \mathrm{~h}$, solvents were removed under reduced pressure. The residue was purified by column chromatography (hexanes:EtOAc 95:5) to afford 6 (42 mg, $0.11 \mathrm{mmol}, 81 \%) .{ }^{1} \mathrm{H}$ NMR (270 $\mathrm{MHz}) \delta 11.21(\mathrm{br} \mathrm{s}, 1 \mathrm{H}), 8.76(\mathrm{dd}, J=8.4$ and $1.2 \mathrm{~Hz}, 1 \mathrm{H}), 7.73(\mathrm{dd}, J=7.7$ and $1.2 \mathrm{~Hz}, 1 \mathrm{H}), 7.60$ $(\mathrm{t}, J=8.2 \mathrm{~Hz}, 1 \mathrm{H}), 4.95(\mathrm{sept}, J=6.2 \mathrm{~Hz}, 2 \mathrm{H}), 1.54(\mathrm{~s}, 9 \mathrm{H}), 1.36(\mathrm{~d}, J=6.2 \mathrm{~Hz}, 6 \mathrm{H}), 1.35(\mathrm{~d}, J=6.2$ $\mathrm{Hz}, 6 \mathrm{H}) ;{ }^{13} \mathrm{C}$ NMR (67.5 MHz) $\delta 185.9(+), 182.3(+), 153.0(+), 148.1(+), 147.0(+), 142.0(+)$, $134.7(-), 131.8(+), 124.4(-), 120.6(-), 114.4(+), 81.1(+), 76.2(-), 76.1(-), 28.2(-), 22.7(-), 22.6$ (-); IR (neat): 2979, 1733, 1585, 1516, 1150, 1090, $755 \mathrm{~cm}^{-1}$.
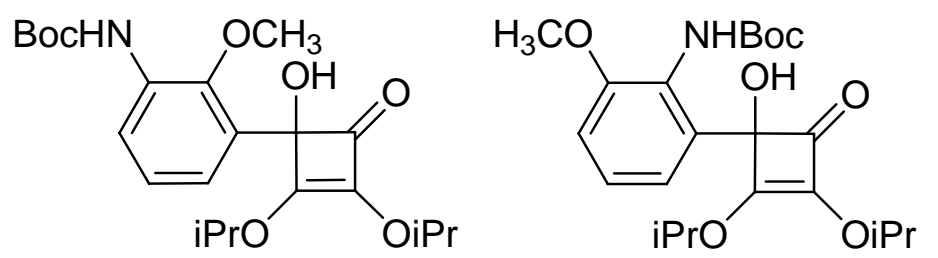

tert-Butyl 2-(1-hydroxy-2,3-diisopropoxy-4-oxocyclobut-2-enyl)-6-methoxyphenylcarbamate (10) and tert-Butyl 3-(1-hydroxy-2,3-diisopropoxy-4-oxocyclobut-2-enyl)-2-

methoxyphenylcarbamate(11) t-BuLi (1.8 mL, 3.02 mmol, 1.8 M in ) was added to 2-Boc aminoanisole $7(227 \mathrm{mg}, 1.02 \mathrm{mmol})$ in THF $(5 \mathrm{~mL})$ at $-40{ }^{\circ} \mathrm{C}$. The reaction was warmed to -10 ${ }^{\circ} \mathrm{C}$ and was stirred for $3 \mathrm{~h}$. Squarate $(370 \mathrm{mg}, 1.83 \mathrm{mmol})$ in THF $(5 \mathrm{~mL})$ was added via cannula at $-20{ }^{\circ} \mathrm{C}$. After stirring at $-20{ }^{\circ} \mathrm{C}$ for $2 \mathrm{~h}$, the reaction was quenched with $10 \% \mathrm{NH}_{4} \mathrm{Cl}$ in $\mathrm{H}_{2} \mathrm{O}$, 
extracted with ether. The combined organic portions were dried over $\mathrm{MgSO}_{4}$, filtered, and then solvents were removed under reduced pressure. The residue was purified by column chromatography (hexane:EtOAc, 95:5, 9:1, 85:15, 8:2) to afford the hydroxycyclobutenones 10 (129 mg, $0.31 \mathrm{mmol}, 30 \%, 40 \%$ BRSM), 11 (64 mg, $0.15 \mathrm{mmol}$ ), and starting material 7 (57 mg, $0.25 \mathrm{mmol})(\mathbf{1 0}){ }^{1} \mathrm{H}$ NMR $(600 \mathrm{MHz}) \delta 7.24(\mathrm{br} \mathrm{s}, 1 \mathrm{H}), 7.22(\mathrm{~d}, J=7.8 \mathrm{~Hz}, 1 \mathrm{H}), 7.17(\mathrm{t}, J=7.8 \mathrm{~Hz}$, $1 \mathrm{H}), 6.90(\mathrm{dd}, J=8.4$ and $1.2 \mathrm{~Hz}, 1 \mathrm{H}$ ), $4.99(\mathrm{sept}, J=6.0 \mathrm{~Hz}, 1 \mathrm{H}), 4.91$ (sept, $J=6.0 \mathrm{~Hz}, 1 \mathrm{H}$ ), 3.84 (s, 3H), $1.50(\mathrm{~s}, 9 \mathrm{H}), 1.46(\mathrm{~d}, J=6.0 \mathrm{~Hz}, 3 \mathrm{H}), 1.45(\mathrm{~d}, J=6.0 \mathrm{~Hz}, 3 \mathrm{H}), 1.31(\mathrm{~d}, J=6.0 \mathrm{~Hz}, 3 \mathrm{H}), 1.22$ $(\mathrm{d}, J=6.0 \mathrm{~Hz}, 3 \mathrm{H}) ;{ }^{13} \mathrm{C}$ NMR $(150 \mathrm{MHz}) \delta 184.3$ (C), 165.5 (C), 155.6 (C), 136.3 (C), 131.9 (C), 127.5 (CH), $124.4(\mathrm{C}), 118.8(\mathrm{CH}), 112.1(\mathrm{CH}), 86.4(\mathrm{C}), 80.1(\mathrm{C}), 77.3(\mathrm{CH}), 73.6(\mathrm{CH}), 55.9\left(\mathrm{CH}_{3}\right)$, $28.2\left(\mathrm{CH}_{3}\right), 22.7\left(\mathrm{CH}_{3}\right), 22.6\left(\mathrm{CH}_{3}\right), 22.5\left(\mathrm{CH}_{3}\right), 22.2\left(\mathrm{CH}_{3}\right) . \quad$ (11) ${ }^{1} \mathrm{H} \mathrm{NMR}(600 \mathrm{MHz}) \delta 8.03(\mathrm{br} \mathrm{s}$, $1 \mathrm{H}), 7.10(\mathrm{t}, J=7.8 \mathrm{~Hz}, 1 \mathrm{H}), 6.88(\mathrm{dd}, J=7.8$ and $1.2 \mathrm{~Hz}, 2 \mathrm{H}), 5.39(\mathrm{~s}, 1 \mathrm{H}), 4.93(\mathrm{sept}, J=6.0 \mathrm{~Hz}$, 1H), $4.92($ sept, $J=6.0 \mathrm{~Hz}, 1 \mathrm{H}), 4.04(\mathrm{~s}, 3 \mathrm{H}), 1.53(\mathrm{~s}, 9 \mathrm{H}), 1.45(\mathrm{~d}, J=6.0 \mathrm{~Hz}, 3 \mathrm{H}), 1.40(\mathrm{~d}, J=6.0$ $\mathrm{Hz}, 3 \mathrm{H}), 1.35(\mathrm{~d}, J=6.0 \mathrm{~Hz}, 3 \mathrm{H}) 1.29(\mathrm{~d}, J=6.0 \mathrm{~Hz}, 3 \mathrm{H}) ;{ }^{13} \mathrm{C} \mathrm{NMR}(150 \mathrm{MHz}) \delta 1837,163.5,152.6$, 146.7, 133.4, 132.6, 129.7, 125.0, 121.1, 119.9, 89.0, 80.9, 77.3, 73.7, 63.4, 28.3, 22.7, 22.7, 22.5, 22.3.<smiles>COc1ccc(C2(O)C(=O)C(OC(C)C)=C2OC(C)C)c(N)c1</smiles><smiles>CCOC1=C(OC(C)C)C(=O)C1(O)c1ccc(NC(C)(C)C)cc1OC</smiles><smiles>COc1cccc(NC(=O)OC(C)(C)C)c1C1(O)C(=O)C(OC(C)C)=C1C(C)C</smiles>

tert-Butyl 2-(1-hydroxy-2,3-diisopropoxy-4-oxocyclobut-2-enyl)-5-methoxyphenylcarbamate (12), tert-Butyl 4-(1-hydroxy-2,3-diisopropoxy-4-oxocyclobut-2-enyl)-3methoxyphenylcarbamate (13) and tert-Butyl 2-(1-hydroxy-2,3-diisopropoxy-4-oxocyclobut-2enyl)-3-methoxyphenylcarbamate (14) tBuLi (2.0 mL, 3.2 mmol, 1.6 M in THF) was added to a 
solution of Bocaminoanisidine $8(226 \mathrm{mg}, 1.01 \mathrm{mmol})$ in THF $(5 \mathrm{~mL})$ at $-45^{\circ} \mathrm{C}$. The reaction was allowed to warm to $-10{ }^{\circ} \mathrm{C}$ for $3 \mathrm{~h}$. Squarate (362 $\mathrm{mg}, 1.82 \mathrm{mmol}$ ) in THF ( $5 \mathrm{~mL}$ ) was added via cannula at $-20{ }^{\circ} \mathrm{C}$. After stirring for $12 \mathrm{~h}$, the reaction was quenched with $10 \% \mathrm{NH}_{4} \mathrm{Cl}$ in $\mathrm{H}_{2} \mathrm{O}$ and extracted with ether. The combined organic portions were dried over $\mathrm{MgSO}_{4}$, filtered, and then solvents were removed under reduced pressure. The residue was purified by column chromatography (hexanes:EtOAc in the order of elution, 95:5, 9:1, 85:15, 8:2) to afford 12 (54 mg, 0.13 mmol, 13\%, 17\% BRSM) , 14 (53 mg, 0.13 mmol, 13\%, 17\% BRSM), 13 (31 mg, 0.074 mmol, 7\%, 10\% BRSM impure), and starting material 8 (54 mg,0.24 mmol) .(12) ${ }^{1} \mathrm{H}$ NMR (270 $\mathrm{MHz}) \delta 8.70(\mathrm{~s}, 1 \mathrm{H}), 7.69(\mathrm{~d}, J=2.7 \mathrm{~Hz}, 1 \mathrm{H}), 7.34(\mathrm{~d}, J=8.6 \mathrm{~Hz}, 1 \mathrm{H}), 6.51(\mathrm{dd}, J=8.4$ and $2.5 \mathrm{~Hz}$, 1H), 4.99 (sept, $J=6.2 \mathrm{~Hz}, 1 \mathrm{H}), 4.91(\mathrm{sept}, J=6.2 \mathrm{~Hz}, 1 \mathrm{H}), 3.80(\mathrm{~s}, 3 \mathrm{H}), 1.53(\mathrm{~s}, 9 \mathrm{H}), 1.48(\mathrm{~d}, J=$ $5.4 \mathrm{~Hz}, 3 \mathrm{H}), 1.46(\mathrm{~d}, J=6.2 \mathrm{~Hz}, 3 \mathrm{H}), 1.32(\mathrm{~d}, J=6.2 \mathrm{~Hz}, 3 \mathrm{H}), 1.24(\mathrm{~d}, J=6.2 \mathrm{~Hz}, 3 \mathrm{H}) . .(14){ }^{1} \mathrm{H} N M R$ (270 MHz) $\delta 8.57(\mathrm{~s}, 1 \mathrm{H}), 7.54(\mathrm{~d}, J=8.4 \mathrm{~Hz}, 1 \mathrm{H}), 7.23(\mathrm{t}, J=8.4 \mathrm{~Hz}, 1 \mathrm{H}), 6.58(\mathrm{~d}, J=8.4 \mathrm{~Hz}, 1 \mathrm{H})$, $4.90($ sept, $J=6.2 \mathrm{~Hz}, 2 \mathrm{H}), 3.75(\mathrm{~s}, 3 \mathrm{H}), 1.51(\mathrm{~s}, 9 \mathrm{H}), 1.42(\mathrm{~d}, J=6.2 \mathrm{~Hz}, 3 \mathrm{H}), 1.38(\mathrm{~d}, J=6.6 \mathrm{~Hz}$, $3 \mathrm{H}), 1.31(\mathrm{~d}, J=6.0 \mathrm{~Hz}, 3 \mathrm{H}), 1.26(\mathrm{~d}, J=6.2 \mathrm{~Hz}, 3 \mathrm{H})$.
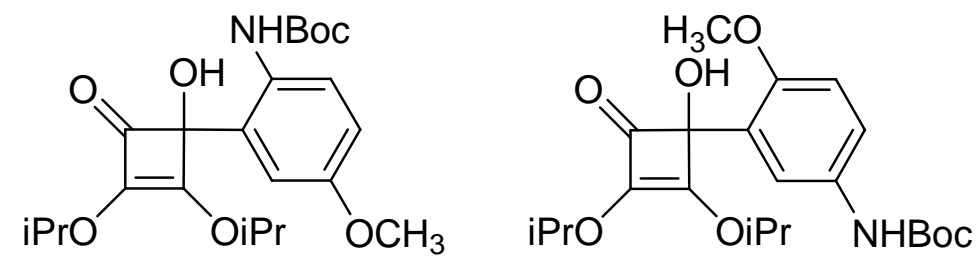

tert-Butyl 2-(1-hydroxy-2,3-diisopropoxy-4-oxocyclobut-2-enyl)-4-methoxyphenylcarbamate (15) and tert-Butyl 3-(1-hydroxy-2,3-diisopropoxy-4-oxocyclobut-2-enyl)-4methoxyphenylcarbamate (16) t-BuLi (2.2 $\mathrm{mL}, 3.52 \mathrm{mmol}, 1.6 \mathrm{M}$ in THF) was added to a solution of $9(229 \mathrm{mg}, 1.02 \mathrm{mmol})$ in $\operatorname{THF}(6 \mathrm{~mL})$ at $-50{ }^{\circ} \mathrm{C}$. The reaction warmed to $-10{ }^{\circ} \mathrm{C}$ and was stirred for $4 \mathrm{~h}$. Squarate (364 mg, $1.84 \mathrm{mmol}$ ) in THF (5 mL) was added via cannula at -20 
${ }^{\circ} \mathrm{C}$. After stirring for $2 \mathrm{~h}$, the reaction was quenched with $10 \% \mathrm{NH}_{4} \mathrm{Cl}$ in $\mathrm{H}_{2} \mathrm{O}$ and extracted with ether. The combine organic portions were dried over $\mathrm{MgSO}_{4}$, filtered and then solvents were removed under reduced pressure. The residue was purified by column chromatography (hexanes:EtOAc in the order of elution, 97:3, 95:5, 9:1) to afford 15 (134 mg, $0.32 \mathrm{mmol}, 32 \%$, $36 \% \mathrm{BRSM}$ ) and 16 (20 mg, $0.047 \mathrm{mmol}, 5 \%, 6 \% \mathrm{BRSM}) .(15){ }^{1} \mathrm{H}$ NMR (270 MHz) $\delta 8.42 \mathrm{br} \mathrm{s}$, $1 \mathrm{H}), 7.74(\mathrm{~d}, J=8.9 \mathrm{~Hz}, 1 \mathrm{H}), 6.98(\mathrm{~d}, J=2.9 \mathrm{~Hz}, 1 \mathrm{H}), 6.81(\mathrm{dd}, J=8.9$ and $3.0 \mathrm{~Hz}, 1 \mathrm{H}), 5.00$ (sept, $J$ $=6.2 \mathrm{~Hz}, 1 \mathrm{H}), 4.90(\operatorname{sept}, J=6.2 \mathrm{~Hz}, 1 \mathrm{H}), 3.76(\mathrm{~s}, 3 \mathrm{H}), 1.50(\mathrm{~s}, 9 \mathrm{H}), 1.46(\mathrm{~d}, J=6.2 \mathrm{~Hz}, 6 \mathrm{H}), 1.31$ $(\mathrm{d}, J=6.2 \mathrm{~Hz}, 6 \mathrm{H}), 1.24(\mathrm{~d}, J=6.2,3 \mathrm{H}) .(16)^{1} \mathrm{H}$ NMR $(270 \mathrm{MHz}), 7.24(\mathrm{~d}, J=8.9 \mathrm{~Hz}, 1 \mathrm{H}), 6.88(\mathrm{~d}, J$ $=8.9 \mathrm{~Hz}, 1 \mathrm{H}), 6.41(\mathrm{~s}, 1 \mathrm{H}), 4.93(\mathrm{sept}, J=6.2 \mathrm{~Hz}, 1 \mathrm{H}), 4.92(\mathrm{sept}, J=6.2 \mathrm{~Hz}, 1 \mathrm{H}), 4.88(\mathrm{~s}, 1 \mathrm{H}), 3.88$ (s, 3H), $1.50(\mathrm{~s}, 9 \mathrm{H}), 1.45(\mathrm{~d}, J=6.0 \mathrm{~Hz}, 3 \mathrm{H}), 1.41(\mathrm{~d}, J=6.0 \mathrm{~Hz}, 3 \mathrm{H}), 1.33(\mathrm{~d}, J=6.0 \mathrm{~Hz}, 3 \mathrm{H}), 1.28$ $(\mathrm{d}, J=6.0 \mathrm{~Hz}, 3 \mathrm{H})$.<smiles>CCCOC1=C(OC(C)C)C(=O)c2c(ccc(NC(C)(C)C)c2O)C1=O</smiles>

\section{tert-Butyl 1,4-dihydro-2,3-diisopropoxy-5-methoxy-1,4-dioxonaphthalen-6-ylcarbamate (18)}

$11(65 \mathrm{mg}, 0.15 \mathrm{mmol})$ was dissolved in toluene $(3 \mathrm{~mL})$ and transferred to a pressure tube. The reaction vessel was sealed and submerged into a $140{ }^{\circ} \mathrm{C}$ oil bath for $20 \mathrm{~h}$. Then the solvents were removed under reduced pressure. The residue was purified by column chromatography (hexanes:EtOAc in the order of elution, 9:1, 85:15, 8:2) to afford 18 (21 mg, $0.05 \mathrm{mmol}, 33 \%$ ). ${ }^{1} \mathrm{H} \mathrm{NMR}(270 \mathrm{MHz}) \delta 8.46(\mathrm{~d}, J=8.6 \mathrm{~Hz}, 1 \mathrm{H}), 7.89(\mathrm{~d}, J=8.6 \mathrm{~Hz}, 1 \mathrm{H}), 7.49(\mathrm{~s}, 1 \mathrm{H}), 4.93(\mathrm{sept}, J=$ $6.0 \mathrm{~Hz}, 1 \mathrm{H}), 4.87(\mathrm{sept}, J=6.2 \mathrm{~Hz}, 1 \mathrm{H}), 3.92,(\mathrm{~s}, 3 \mathrm{H}), 1.55(\mathrm{~s}, 9 \mathrm{H}), 1.36(\mathrm{~d}, J=6.2 \mathrm{~Hz}, 6 \mathrm{H}), 1.34(\mathrm{~d}$, $J=6.2 \mathrm{~Hz}, 6 \mathrm{H})$. 


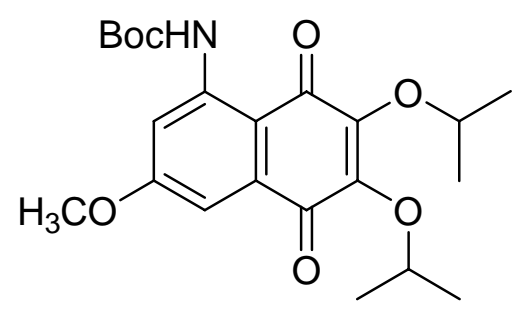

tert-Butyl 1,4-dihydro-2,3-diisopropoxy-6-methoxy-1,4-dioxonaphthalen-8-ylcarbamate (19)

Compound $12(56 \mathrm{mg}, 0.13 \mathrm{mmol})$ was dissolved in toluene $(3 \mathrm{~mL})$ and transferred to a pressure tube. The vessel was sealed then submerged in a $120^{\circ} \mathrm{C}$ oil bath. After stirring $12 \mathrm{~h}$, the solvents were removed under reduced pressure. The residue was purified by column chromatography (hexanes:EtOAc, 95:5) to afford 19 (15 mg, $0.036 \mathrm{mmol}, 27 \%, 33 \% \mathrm{BRSM}$ ). $1 \mathrm{H}$ $\operatorname{NMR}(270 \mathrm{MHz}) \delta 11.4(\mathrm{~s}, 1 \mathrm{H}), 8.30(\mathrm{~d}, J=2.7 \mathrm{MHz}, 1 \mathrm{H}), 7.28(\mathrm{~d}, J=2.7 \mathrm{~Hz}, 1 \mathrm{H}), 4.99$ (sept, $J=$ $6.2 \mathrm{~Hz}, 1 \mathrm{H}), 4.86(\mathrm{sept}, J=6.2 \mathrm{~Hz}, 1 \mathrm{H}), 1.53(\mathrm{~s}, 9 \mathrm{H}), 1.35(\mathrm{~d}, J=5.9,6 \mathrm{H}), 1.33(\mathrm{~d}, J=5.7 \mathrm{~Hz}, 6 \mathrm{H})$.<smiles>CCCOC1=C(OCCC)C(=O)c2c(NC(C)(C)C)ccc(O)c2C1=O</smiles>

tert-Butyl 1,4-dihydro-2,3-diisopropoxy-5-methoxy-1,4-dioxonaphthalen-8-ylcarbamate (20) Compound 15 (25 mg, $0.059 \mathrm{mmol})$ was dissolved in toluene $(2 \mathrm{~mL})$ and transferred to a pressure tube. The vessel was sealed and submerged in a $170{ }^{\circ} \mathrm{C}$ oil bath and was stirred for 12 h. Then the solvents were removed under reduced pressure. The residue was purified by column chromatography (hexanes:EtOAc, 9:1) to afford the naphthoquinone 20 (6 mg, 0.014 mmol, 24\%). ${ }^{1} \mathrm{H}$ NMR $(600 \mathrm{MHz}) \delta 11.3(\mathrm{br} \mathrm{s}, 1 \mathrm{H}), 8.76(\mathrm{~d}, J=9.6 \mathrm{~Hz}, 1 \mathrm{H}), 7.29(\mathrm{~d}, J=9.6 \mathrm{~Hz}, 1 \mathrm{H})$, $4.94($ sept, $J=6.0 \mathrm{~Hz}, 1 \mathrm{H}), 4.87(\mathrm{sept}, J=6.0 \mathrm{~Hz}, 1 \mathrm{H}), 3.97(\mathrm{~s}, 3 \mathrm{H}), 1.53(\mathrm{~s}, 9 \mathrm{H}), 1.34(\mathrm{~d}, J=6.2 \mathrm{~Hz}$, 12H). ${ }^{13} \mathrm{C}$ NMR (150 MHz) $\delta 186.1$ (C), 181.4 (C), 154.9 (C), 153.4 (C), 148.0 (C), 146.0 (C), 136.2 
(C), $126.9(\mathrm{CH}), 120.9(\mathrm{CH}), 118.4(\mathrm{C}), 115.8(\mathrm{C}), 80.9(\mathrm{C}), 76.0(\mathrm{CH}), 75.8(\mathrm{CH}), 56.8(\mathrm{CH}), 28.3$

$\left(\mathrm{CH}_{3}\right), 27.7$ (C), $22.8\left(\mathrm{CH}_{3}\right), 22.6\left(\mathrm{CH}_{3}\right) ; \mathrm{IR}$ (neat): 2977, 1766, 1625, 1505, 1154, 1099, $765 \mathrm{~cm}^{-1}$. HRMS calcd for $\mathrm{C}_{22} \mathrm{H}_{30} \mathrm{NO}_{7}\left(\mathrm{M}+\mathrm{H}^{+}\right): 420.2017$, Found:420.2022.<smiles>CC(C)OC1=C(OC(C)C)C(=O)c2c(NC(C)(C)C)ccnc2C1=O</smiles>

tert-Butyl 5,8-dihydro-6,7-diisopropoxy-5,8-dioxoquinolin-4-ylcarbamate (27) t-BuLi (2.1 mL, $3.36 \mathrm{mmol}, 1.6 \mathrm{M}$ in THF) was added to tert-butyl pyridin-4-ylcarbamate 23 (201 mg, 1.03 $\mathrm{mmol}$ ) in THF (5 mL) at $-50{ }^{\circ} \mathrm{C}$. After stirring for $2 \mathrm{~h}$, diisopropryl squarate (370 mg, $1.87 \mathrm{mmol}$ ) in THF (6 mL)was added via cannula. After stirring for $7 \mathrm{~h}$, the reaction was quenched with $10 \%$ $\mathrm{NH}_{4} \mathrm{Cl}$ in $\mathrm{H}_{2} \mathrm{O}$, extracted with ether, dried over $\mathrm{MgSO}_{4}$, filtered and then solvents were removed under reduced pressure. The residue was dissolved in toluene and transferred to a pressure tube. The vessel was sealed and then submerged in a $120^{\circ} \mathrm{C}$ oil bath. After stirring for $30 \mathrm{~min}$, the solvents were removed under reduced pressure. The residue was purified by column chromatography (hexanes;EtOAc, in order of elution: 9:1, 85:15, 8:2, 7:3) to afford 23 (129 mg, $0.33 \mathrm{mmol}, 32 \%) .{ }^{1} \mathrm{H}$ NMR $(600 \mathrm{MHz}) \delta 8.88(\mathrm{~s}, 1 \mathrm{H}), 8.42(\mathrm{~s}, 1 \mathrm{H}), 8.30(\mathrm{~d}, J=6.01 \mathrm{H}), 8.13(\mathrm{~d}, J=$ $6.0 \mathrm{~Hz}, 1 \mathrm{H}$ ), 5.00 (sept, $J=6.0 \mathrm{~Hz}, 1 \mathrm{H}), 4.92(\mathrm{sept}, J=6.0 \mathrm{~Hz}, 1 \mathrm{H}), 1.53(\mathrm{~s}, 9 \mathrm{H}), 1.46(\mathrm{~d}, J=6.0 \mathrm{~Hz}$, $6 \mathrm{H}), 1.32(\mathrm{~d}, J=6.0 \mathrm{~Hz}, 3 \mathrm{H}), 1.25(\mathrm{~d}, J=6.0 \mathrm{~Hz}, 1 \mathrm{H}) ;{ }^{13} \mathrm{C} \mathrm{NMR}(150 \mathrm{MHz}) \delta 183.2,165.2,152.5$, $150.4,147.2,145.4,132.1,121.9,113.5,85.2,81.2,78.2,74.2,28.3,22.8,22.7,22.6,22.3$.<smiles>CNC(=O)Nc1ccccc1C1(O)C(=O)C(OC(C)C)=C1OC(C)C</smiles> 
$\mathrm{N}$-(2-(1-hydroxy-2,3-diisopropoxy-4-oxocyclobut-2-enyl)phenyl)pivalamide (36) At $0{ }^{\circ} \mathrm{C}$ under

$\mathrm{N}_{2}$ atmosphere, $\mathrm{nBuLi}(9.5 \mathrm{~mL}, 15.2 \mathrm{mmol}, 1.6 \mathrm{M}$ in hexanes) was added to a solution of $\mathrm{N}$ phenylpivalamide $35(890 \mathrm{mg}, 5.02 \mathrm{mmol})$ in ether $(10 \mathrm{~mL})$ and THF $(7.5 \mathrm{~mL})$. After stirring for 2 $\mathrm{h}$, the mixture was cooled to $-78^{\circ} \mathrm{C}$ and squarate $(1.97 \mathrm{~g}, 9.94 \mathrm{mmol})$ in THF $(3 \mathrm{~mL})$ was added via cannula. After stirring for $4 \mathrm{~h}$ at $\mathrm{rt}$, the was quenched with $\mathrm{H}_{2} \mathrm{O}$ and extracted with ether. The combined organic portions were dried over $\mathrm{MgSO}_{4}$, filtered, and then the solvents were removed under reduced pressure. The residue was purified by column chromatography (hexane:EtOAc, 100:0, 95:5, 9:1, 85:15, 8:2) to afford 36 (885 mg, 2.36 mmol 45\%, 67\% BRSM).

${ }^{1} \mathrm{H}$ NMR $(600 \mathrm{MHz}) \delta 9.55$ (br s, 1H), $9.05(\mathrm{~d}, J=9.0 \mathrm{~Hz}, 1 \mathrm{H}), 7.38(\mathrm{dd}, J=7.8$ and $1.2 \mathrm{~Hz}, 1 \mathrm{H})$, $7.31(\mathrm{dd}, J=7.8$ and $1.2 \mathrm{~Hz}, 1 \mathrm{H}), 7.04(\mathrm{dt}, J=7.2$ and 1.2, $1 \mathrm{H}), 5.03(\mathrm{sept}, J=6.0 \mathrm{~Hz}, 1 \mathrm{H}), 4.91$ (sept, $J=6.0 \mathrm{~Hz}, 1 \mathrm{H}), 3.22(\mathrm{~s}, 1 \mathrm{H}), 1.49(\mathrm{~d}, J=6.0 \mathrm{~Hz}, 3 \mathrm{H}), 1.47(\mathrm{~d}, J=6.0 \mathrm{~Hz}, 3 \mathrm{H}), 1.34(\mathrm{~s}, 9 \mathrm{H})$, $1.32(\mathrm{~d}, J=6.0 \mathrm{~Hz}, 3 \mathrm{H}), 1.24(\mathrm{~d}, J=6.0 \mathrm{~Hz}, 3 \mathrm{H}) ;{ }^{13} \mathrm{C}$ NMR $(150 \mathrm{MHz}) \delta 184.3(\mathrm{C}), 177.8(\mathrm{C}), 165.9$ (C), $137.1(\mathrm{C}), 132.0(\mathrm{C}), 129.4(\mathrm{CH}), 128.6(\mathrm{C}), 126.3(\mathrm{CH}), 124.5(\mathrm{CH}), 87.1(\mathrm{C}), 77.9(\mathrm{CH}), 74.0$ $(\mathrm{CH}), 39.7(\mathrm{C}), 27.4\left(\mathrm{CH}_{3}\right), 22.8\left(\mathrm{CH}_{3}\right), 22.7\left(\mathrm{CH}_{3}\right), 22.6\left(\mathrm{CH}_{3}\right), 22.3\left(\mathrm{CH}_{3}\right)$.<smiles>CC(C)OC1=C(OC(C)C)C(=O)c2c(N)cccc2C1=O</smiles>

N-(1,4-dihydro-2,3-diisopropoxy-1,4-dioxonaphthalen-5-yl)pivalamide (37) Compound 36 (100 $\mathrm{mg}, 0.27 \mathrm{mmol}$ ) and Proton Sponge $(57 \mathrm{mg}, 0.27 \mathrm{mmol})$ were dissolved in xylenes $(40 \mathrm{~mL})$ and transferred to a $350 \mathrm{~mL}$ pressure tube then the reaction vessel was sealed and submerged in a $120^{\circ} \mathrm{C}$ sand bath. After heating for $2 \mathrm{~h}$, solvents were removed under reduced pressure. The residue was purified via column chromatography (hexanes:EtOAc in the order of elution, 98:2, 
95:5, 9:1) to afford 37 (56 mg, $0.27 \mathrm{mmol}, 64 \%) .{ }^{1} \mathrm{H}$ NMR (270 MHz) $\delta 12.2(\mathrm{br} \mathrm{s}, 1 \mathrm{H}), 9.16$ (dd, J $=8.7$ and $1.2 \mathrm{~Hz}, 1 \mathrm{H}), 7.82(\mathrm{dd}, J=7.4$ and $1.2 \mathrm{~Hz}, 1 \mathrm{H}), 7.63(\mathrm{t}, J=7.7 \mathrm{~Hz}, 1 \mathrm{H}), 5.04$ (sept, $J=6.0$ $\mathrm{Hz}, 1 \mathrm{H}), 1.40(\mathrm{~d}, J=6.0 \mathrm{~Hz}, 6 \mathrm{H}), 1.34(\mathrm{~s}, 9 \mathrm{H})$.<smiles>CCCNc1cccc2c1C(=O)C(OC(C)C)=C(O)C2=O</smiles>

N-(1,4-dihydro-2-hydroxy-3-isopropoxy-1,4-dioxonaphthalen-5-yl)pivalamide (38) Compound 36 (100 mg, $0.27 \mathrm{mmol}$ ) and Proton Sponge (101 mg, $0.47 \mathrm{mmol}$ ) were dissolved in xylenes (20 $\mathrm{mL}$ ) and transferred to a pressure tube then the reaction vessel sealed and submerged in a 170 ${ }^{\circ} \mathrm{C}$ oil bath. After heating for 2 days, the solvents were removed under reduced pressure. The residue was purified via column chromatography (hexanes:EtOAc in the order of elution, 98:2, 95:5, 9:1) to afford 38 (40 mg, $0.11 \mathrm{mmol}, 40 \%) .{ }^{1} \mathrm{H}$ NMR (270 MHz) $\delta 12.2(\mathrm{br} \mathrm{s}, 1 \mathrm{H}), 9.10$ (d, J $=8.6 \mathrm{~Hz}, 1 \mathrm{H}), 7.81(\mathrm{~d}, J=7.4 \mathrm{~Hz}, 1 \mathrm{H}), 7.65(\mathrm{t}, J=7.9 \mathrm{~Hz}, 1 \mathrm{H}), 4.98(\mathrm{sept}, J=6.2 \mathrm{~Hz}, 1 \mathrm{H}), 4.90$ (sept, J = 6.2 Hz, 1H), $1.39(\mathrm{~s}, 9 \mathrm{H}), 1.35(\mathrm{~d}, J=6.2 \mathrm{~Hz}, 12 \mathrm{H}), 13 \mathrm{C}$ NMR $(67.5 \mathrm{MHz}) \delta 185.9(+)$, $181.9(+), 179.1(+), 142.5(+), 142.1(+), 138.9(+), 134.6(-), 129.7(+), 127.4(-), 121.6(-), 114.9$ $(+), 75.8(-), 40.6(+), 27.6(-), 22.7(-)$; IR (neat) 3263, 2973, 1657, 1631, 1284, 1184, $757 \mathrm{~cm}^{-1}$.<smiles>CC(C)OC1=C(OC(C)C)C(O)(c2ccccc2[N+](=O)[O-])C1=O</smiles>

4-hydroxy-2,3-diisopropoxy-4-(2-nitrophenyl)cyclobut-2-enone (39) At - $40{ }^{\circ} \mathrm{C}$, Phenylmagnesium chloride (7.2 mL, $14.76 \mathrm{mmol}, 2.0 \mathrm{M}$ in THF) was added to a solution of 2iodonitrobenzene $(3.25 \mathrm{~g}, 13.05 \mathrm{mmol})$ in THF $(30 \mathrm{~mL})$ under $\mathrm{N}_{2}$ atmosphere. After stirring for 
$10 \mathrm{~min}$, squarate $(3.36 \mathrm{~g}, 16.95 \mathrm{mmol})$ in THF $(20 \mathrm{~mL})$ was added via cannula. After stirring for $13 \mathrm{~h}$, the reaction was quenched with $10 \% \mathrm{NH}_{4} \mathrm{Cl}$ in $\mathrm{H}_{2} \mathrm{O}$, extracted with ether. The combined organic portions were dried over $\mathrm{MgSO}_{4}$, filtered, and then solvents were removed under reduced pressure. The residue was purified by column chromatography (hexanes:EtOAc in the order of elution, 95:5, 9:1, 85:15, 8:2) to afford the alcohol 39 (3.03 g, $9.43 \mathrm{mmol}, 72 \%) .{ }^{1} \mathrm{H}$ NMR $(600 \mathrm{MHz}) \delta 7.96(\mathrm{dd}, J=7.8$ and $1.2 \mathrm{~Hz}, 1 \mathrm{H}), 7.79(\mathrm{dd}, J=7.8$ and $1.2 \mathrm{~Hz}, 1 \mathrm{H}), 7.60(\mathrm{dt}, J=7.8$ and $1.2 \mathrm{~Hz}, 1 \mathrm{H}), 7.47(\mathrm{dt}, J=7.8$ and $1.2 \mathrm{~Hz}, 1 \mathrm{H}), 4.95($ sept, $J=6.0 \mathrm{~Hz}, 1 \mathrm{H}), 4.92(\operatorname{sept}, J=6.0 \mathrm{~Hz}$, 1H), $4.71(\mathrm{br} \mathrm{s}, 1 \mathrm{H}), 1.44(\mathrm{~d}, J=6.0 \mathrm{~Hz}, 3 \mathrm{H}), 1.38(\mathrm{~d}, J=6.0 \mathrm{~Hz}, 3 \mathrm{H}), 1.32(\mathrm{~d}, J=6.0 \mathrm{~Hz}, 3 \mathrm{H}), 1.24$ $(\mathrm{d}, J=6.0 \mathrm{~Hz}, 3 \mathrm{H}) ;{ }^{13} \mathrm{C}$ NMR $(150 \mathrm{MHz}) \delta 181.1$ (C), 164.2 (C), 149.3 (C), 133.5 (CH), 132.3 (C), $132.2(\mathrm{C}), 129.3(\mathrm{CH}), 128.6(\mathrm{CH}), 125.0(\mathrm{CH}), 84.6(\mathrm{C}), 77.8(\mathrm{CH}), 74.1(\mathrm{CH}), 22.7\left(\mathrm{CH}_{3}\right), 22.7\left(\mathrm{CH}_{3}\right)$, 22.3 $\left(\mathrm{CH}_{3}\right), 22.3\left(\mathrm{CH}_{3}\right)$; HRMS Calcd For $\mathrm{C}_{6} \mathrm{H}_{19} \mathrm{NO}_{6} \mathrm{Na}\left(\mathrm{M}+\mathrm{Na}^{+}\right)$: 344.1110 Found: 344.1105 .<smiles>CC(C)Oc1c(O)n(O)c2ccccc2c1=O</smiles>

2,3-diisopropyl-1-hydroxy-4(1H)-quinolinone (40) Hydroxycyclobutenedone 39 in xylenes was placed in a pressure tube then the reaction vessel sealed and submerged in a $160{ }^{\circ} \mathrm{C}$ oil bath. After stirring for $1 \mathrm{~h}$, the solvent was removed under reduced pressure. The residue was purified by column chromatography (hexanes:EtOAc, 85:15) to afford $\mathbf{4 0}$ (59 mg, $0.21 \mathrm{mmol}$ ). ${ }^{1} \mathrm{H}$ $\operatorname{NMR}(600 \mathrm{MHz}) \delta 8.00(\mathrm{~d}, J=8.4 \mathrm{~Hz}, 1 \mathrm{H}), 7.74(\mathrm{~d}, J=8.4 \mathrm{~Hz}, 1 \mathrm{H}), 7.54(\mathrm{dt}, J=8.4$ and $1.2 \mathrm{~Hz})$, $7.35(\mathrm{dt}, J=8.4$ and $1.2 \mathrm{~Hz}, 1 \mathrm{H}), 6.53(\mathrm{br} \mathrm{s}, 1 \mathrm{H}), 5.63(\mathrm{sept}, J=6.0 \mathrm{~Hz}, 1 \mathrm{H}), 4.65$ (sept, $J=6.0 \mathrm{~Hz}$, 1H), $1.45(\mathrm{~d}, J=6.0 \mathrm{~Hz}, 6 \mathrm{H}), 1.37(\mathrm{~d}, J=6.0 \mathrm{~Hz}, 6 \mathrm{H}) ;{ }^{13} \mathrm{C} N M R(150 \mathrm{MHz}) \delta 156.1(\mathrm{C}), 151.0(\mathrm{C})$, 
$142.9(\mathrm{C}), 128.4(\mathrm{CH}), 126.7(\mathrm{CH}), 125.5(\mathrm{C}), 123.1(\mathrm{CH}), 121.6(\mathrm{CH}), 118.1(\mathrm{C}), 68.4\left(\mathrm{CH}_{3}\right), 22.5$

$\left(\mathrm{CH}_{3}\right), 22.1\left(\mathrm{CH}_{3}\right)$; HRMS Calcd for $\mathrm{C}_{15} \mathrm{H}_{19} \mathrm{NO}_{4}\left(\mathrm{M}+\mathrm{H}^{+}\right)$: 278.1387 Found: 278.1388 .

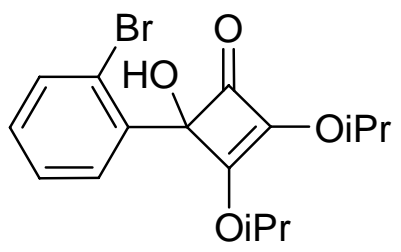

4-(2-bromophenyl)-4-hydroxy-2,3-diisopropoxycyclobut-2-enone (49) At -110 ${ }^{\circ} \mathrm{C}, n \mathrm{BuLi}(2.2$

$\mathrm{mL}, 3.96 \mathrm{mmol}, 1.8 \mathrm{M}$ in hexanes) was added to a solution of 1-iodo-2-bromobenzene (1.068 $\mathrm{g}$, $3.76 \mathrm{mmol})$ in a THF $(60 \mathrm{~mL})$ and ether $(60 \mathrm{~mL})$. After $30 \mathrm{mins}$, diisopropyl squarate $(810 \mathrm{mg}$, $4.08 \mathrm{mmol})$ dissolved in THF $(10 \mathrm{~mL})$ was added via cannula. After stirring overnight, the reaction was quenched with $10 \% \mathrm{NH}_{4} \mathrm{Cl}$ in $\mathrm{H}_{2} \mathrm{O}$ and extracted with EtOAc. The combined organic portions were dried over $\mathrm{MgSO}_{4}$, filtered, then the solvents were removed under reduced pressure. The residue was purified by column chromatography (hexanes:EtOAC, 9:1) to afford $49(1.18 \mathrm{~g}, 3.32 \mathrm{mmol}, 88 \%)$ as a colorless oil. ${ }^{1} \mathrm{H}$ NMR $(600 \mathrm{MHz}) \delta 7.63(\mathrm{dd}, \mathrm{J}=7.8$ and $1.8 \mathrm{~Hz}, 1 \mathrm{H}), 7.58(\mathrm{dd}, J=7.8$ and $1.2 \mathrm{~Hz}, 1 \mathrm{H}), 7.30(\mathrm{dt}, J=7.8$ and $1.2 \mathrm{~Hz}, 1 \mathrm{H}), 7.16(\mathrm{dt}, J=$ 7.8 and $1.8 \mathrm{~Hz}, 1 \mathrm{H}), 4.95$ (sept, $J=6.0 \mathrm{~Hz}, 2 \mathrm{H}$ ), 3.69 (br s, 1H), $1.44(\mathrm{~d}, J=6.6 \mathrm{~Hz}, 3 \mathrm{H}), 1.42(\mathrm{~d}, J$ $=6.0 \mathrm{~Hz}, 3 \mathrm{H}), 1.34(\mathrm{~d}, J=6.0 \mathrm{~Hz}, 1 \mathrm{H}), 1.29(\mathrm{~d}, J=6.0 \mathrm{~Hz}, 3 \mathrm{H}) ;{ }^{13} \mathrm{C} N M R(150 \mathrm{MHz}) \delta 182.3(\mathrm{C})$, 164.2 (C), 136.9 (C), $134.4(\mathrm{CH}), 133.8(\mathrm{C}), 129.7(\mathrm{CH}), 129.2(\mathrm{CH}), 127.5(\mathrm{CH}), 120.7(\mathrm{C}), 88.1(\mathrm{C})$, $77.5(\mathrm{CH}), 73.9(\mathrm{CH}), 22.9\left(\mathrm{CH}_{3}\right), 22.8\left(\mathrm{CH}_{3}\right), 22.6\left(\mathrm{CH}_{3}\right), 22.3\left(\mathrm{CH}_{3}\right)$; IR (neat) 3379, 2981, 1771, 1599, 1316, 1091, 942, $750 \mathrm{~cm}^{-1} \mathrm{HRMS}$ Calcd for $\mathrm{C}_{16} \mathrm{H}_{20} \mathrm{BrO}_{4}\left(\mathrm{M}+\mathrm{H}^{+}\right)$: 355.0539 Found: 355.0540<smiles>CC(C)OC1=C(OC(C)C)C(=O)c2c(Br)cccc2C1=O</smiles> 
5-bromo-2,3-diisopropoxynaphthalene-1,4-dione (50) Compound 49 (70 mg, $0.20 \mathrm{mmol}$ ) was dissolved in xylenes $(5 \mathrm{~mL})$ and transferred to a pressure tube. The vessel was sealed and then submerged in a $135{ }^{\circ} \mathrm{C}$ oil bath. After stirring for $5 \mathrm{~h}$, the solvent was removed under reduced pressure. The residue was purified by column chromatography (hexanes:EtOAc, 95:5) to afford $50(48 \mathrm{mg}, 0.14 \mathrm{mmol}, 70 \%)$ as a light orange oil. ${ }^{1} \mathrm{H}$ NMR $(600 \mathrm{MHz}) \delta 8.11(\mathrm{dd}, J=7.8$ and 1.2 $\mathrm{Hz}, 1 \mathrm{H}), 7.92(\mathrm{dd}, J=7.8$ and $1.2 \mathrm{~Hz}, 1 \mathrm{H}), 7.47(\mathrm{t}, J=7.8$ and $1.2 \mathrm{~Hz}, 1 \mathrm{H}), 4.96($ sept $J=6.0 \mathrm{~Hz}$, 1H), 4.92, sept, $J=6.0 \mathrm{~Hz}, 1 \mathrm{H}), 1.37(\mathrm{~d}, J=6.0 \mathrm{~Hz}, 6 \mathrm{H}), 1.35(\mathrm{~d}, J=6.0 \mathrm{~Hz}, 6 \mathrm{H}) ;{ }^{13} \mathrm{C}$ NMR $(150$ $\mathrm{MHz}) \delta 181.4(\mathrm{C}), 180.9$ (C), $148.8(\mathrm{C}), 146.5(\mathrm{C}), 140.6(\mathrm{CH}), 134.1(\mathrm{C}), 133.2(\mathrm{CH}), 128.4(\mathrm{C})$, $126.4(\mathrm{CH}), 121.7(\mathrm{C}), 76.5(\mathrm{CH}), 76.5(\mathrm{CH}), 22.8\left(\mathrm{CH}_{3}\right), 22.7\left(\mathrm{CH}_{3}\right)$; IR (neat) 2979, 1664, 1607, 1194, 11096, 1000, $747 \mathrm{~cm}^{-1}$; HRMS Calcd for $\mathrm{C}_{16} \mathrm{H}_{18} \mathrm{BrO}_{4}\left(\mathrm{M}+\mathrm{H}^{+}\right)$: 353.0383 Found:353.03837.<smiles>CCCOc1c(-c2ccccc2NC(C)(C)C)c(=O)c1=O</smiles>

tert-Butyl 2-(2-isopropoxy-3,4-dioxocyclobut-1-enyl)phenylcarbamate (61) At $0{ }^{\circ} \mathrm{C}$, TFAA (1.6 $\mathrm{mL}, 11.5 \mathrm{mmol})$ was added to a solution of $5(3.585 \mathrm{~g}, 9.16 \mathrm{mmol})$ and pyridine $(1.0 \mathrm{~mL}, 12.9$ mmol) in ether ( $135 \mathrm{~mL}$ ). After stirring for $45 \mathrm{~min}$, the reaction was quenched with $\mathrm{H}_{2} \mathrm{O}$ and extracted with EtOAc. The mixture was dried over $\mathrm{MgSO}_{4}$, filtered, and then solvents were removed under reduced pressure. The residue was purified by column chromotograpy (hexanes:EtOAc, 9:1) to afford $61(2.32 \mathrm{~g}, 6.45 \mathrm{mmol}, 76 \%)$ in a yellow solid. ${ }^{1} \mathrm{H} \mathrm{NMR}(600 \mathrm{MHz})$ $\delta 9.50($ br s, 1H), $8.23(\mathrm{~d}, J=8.4 \mathrm{~Hz}, 1 \mathrm{H}), 7.83(\mathrm{~d}, J=7.2 \mathrm{~Hz}, 1 \mathrm{H}), 7.42(\mathrm{t}, J=7.2 \mathrm{~Hz}, 1 \mathrm{H}), 7.04(\mathrm{t}, J$ $=7.2 \mathrm{~Hz}, 1 \mathrm{H}), 5.65(\mathrm{sept}, J=6.0,1 \mathrm{H}), 1.55(\mathrm{~d}, J=6.6 \mathrm{~Hz}, 6 \mathrm{H}), 1.51(\mathrm{~s}, 9 \mathrm{H}) ;{ }^{13} \mathrm{C} \mathrm{NMR}(150 \mathrm{MHz}) \delta$ 193.7 (C), 193.3 (C), 188.8 (C), 173.5 (C), 152.9 (C), 139.6 (C), 133.9 (CH), $128.8(\mathrm{CH}), 122.5(\mathrm{CH})$, 
$120.8(\mathrm{CH}), 117.6(\mathrm{C}), 81.3(\mathrm{CH}), 80.5(\mathrm{C}), 28.2\left(\mathrm{CH}_{3}\right), 22.8\left(\mathrm{CH}_{3}\right)$; IR (neat) 2981, 1770, 1716, 1562, 1388, 1130, $762 \mathrm{~cm}^{-1}$, HRMS cald for $\mathrm{C}_{18} \mathrm{H}_{22} \mathrm{NO}_{5}\left(\mathrm{M}+\mathrm{H}^{+}\right) 332.1493$, Found 332.1493 .<smiles>CC(C)Oc1c(-c2ccccc2Nc2ccccn2)c(=O)c1=O</smiles>

N-(2-(2-isopropoxy-3,4-dioxocyclobut-1-enyl)phenyl)pivalamide (62) TFAA (0.5 mL, $3.5 \mathrm{mmol})$ was added to a solution of 36 (700 mg, $1.87 \mathrm{mmol})$ and pyridine $(1 \mathrm{~mL}, 12.4 \mathrm{mmol})$ in ether (70 $\mathrm{mL}$ ). After stirring for $1 \mathrm{~h}$, the reaction was quenched with $\mathrm{NH}_{4} \mathrm{Cl}$ in $\mathrm{H}_{2} \mathrm{O}$ and extracted with ether. The combined organic portions were dried over $\mathrm{MgSO}_{4}$, filtered, and then the solvents were removed under reduced pressure. The residue was purified by column chromatography (hexanes:EtOAC, 9:1) to afford 62 (446 mg, $1.42 \mathrm{mmol}, 76 \%$ ) as a light yellow solid. ${ }^{1} \mathrm{H}$ NMR $(600 \mathrm{MHz}) \delta 9.93(\mathrm{~s}, 1 \mathrm{H}), 8.35(\mathrm{~d}, J=8.4 \mathrm{~Hz}, 1 \mathrm{H}), 7.77(\mathrm{dd}, J=7.8$ and $1.8 \mathrm{~Hz}, 1 \mathrm{H}), 7.50(\mathrm{dt}, J=$ 8.4 and $1.2 \mathrm{~Hz}, 1 \mathrm{H}), 7.16(\mathrm{t}, J=7.2 \mathrm{~Hz}, 1 \mathrm{H}), 5.70$ (sept, $J=6.0 \mathrm{~Hz}, 1 \mathrm{H}), 1.59(\mathrm{~d}, J=6.6 \mathrm{~Hz}, 6 \mathrm{H})$, $1.35(\mathrm{~s}, 9 \mathrm{H}) ;{ }^{13} \mathrm{C}$ NMR (150 MHz) $\delta 194.5(+), 194.3(+), 189.0(+), 178.3(+), 174.2(+), 139.3(+)$, $133.6(-), 128.8(-), 124.3(-), 123.8(-), 118.7(+), 81.6(-), 40.2(+), 27.2(-), 23.0(-)$; IR (neat) $2955,1779,1550,1387,1159,767 \mathrm{~cm}^{-1}$; HRMS Calcd for $\mathrm{C}_{18} \mathrm{H}_{22} \mathrm{NO}_{4}\left(\mathrm{M}+\mathrm{H}^{+}\right): 316.1543$ Found 316.1543.<smiles>CC(C)OC1=C(c2ccccc2NC(=O)c2ccccc2)C(=O)C1(O)c1ccccc1</smiles>

tert-Butyl 2-(3-hydroxy-2-isopropoxy-4-oxo-3-phenylcyclobut-1-enyl)phenylcarbamate (63) At $-78{ }^{\circ} \mathrm{C}$ under $\mathrm{N}_{2}$ atmosphere, PhLi (1.0 mL, $1.5 \mathrm{mmol}, 1.5 \mathrm{M}$ in diButylether) was added to a 
solution of $61(302 \mathrm{mg}, 0.91 \mathrm{mmol})$ in THF $(10 \mathrm{~mL})$. After stirring for $2 \mathrm{~h}$ at $-50{ }^{\circ} \mathrm{C}$, the reaction was quenched with $10 \% \mathrm{NH}_{4} \mathrm{Cl}$ in $\mathrm{H}_{2} \mathrm{O}$. It was extracted with EtOAc, dried over $\mathrm{MgSO}_{4}$, then filtered. The solvents were removed under reduced pressure and the residue was purified by column chromatography (hexanes:EtOAc in the order of elution, 98:2, 95:5, 9:1) to afford 63 (330 mg, $0.81 \mathrm{mmol}, 89 \%) .{ }^{1} \mathrm{H}$ NMR $(270 \mathrm{MHz}) \delta 9.43$ (br s, 1H), 8.14 ( (d, J=8.2 Hz, 1H), 7.68 $(\mathrm{d}, J=7.7 \mathrm{~Hz}, 1 \mathrm{H}), 7.53(\mathrm{~d}, J=8.2 \mathrm{~Hz}, 2 \mathrm{H}), 7.41-7.24(\mathrm{~m}, 4 \mathrm{H}), 6.99(\mathrm{dt}, J=7.4$ and $1.2 \mathrm{~Hz}, 1 \mathrm{H})$, 4.87 (sept, $J=6.2 \mathrm{~Hz}, 1 \mathrm{H}), 1.50(\mathrm{~s}, 9 \mathrm{H}), 1.45(\mathrm{~d}, J=6.2 \mathrm{~Hz}, 3 \mathrm{H}), 1.10(\mathrm{~d}, J=6.2 \mathrm{~Hz}, 3 \mathrm{H}) ;{ }^{13} \mathrm{C} \mathrm{NMR}$ (67.5 MHZ) $\delta 187.9(+), 179.7(+), 153.6(+), 136.8(+), 136.2(+), 129.4(-), 128.7(-), 128.7(-)$, $128.4(-), 125.5(-), 125.2(+), 122.4(-), 120.3(-), 118.2(+), 91.1(+), 80.4(-), 80.0(+), 28.4(-)$, $22.9(-), 22.5$ (-), IR (neat) 3385, 2981, 1731, 1580, 1300, 1157, and $750 \mathrm{~cm}^{-1}$, HRMS Calcd for $\mathrm{C}_{24} \mathrm{H}_{28} \mathrm{NO}_{5}\left(\mathrm{M}+\mathrm{H}^{+}\right):$410.1962, Found 410.1964.<smiles>CC(C)Nc1ccccc1C1=C(OC(C)C)C(O)(c2ccccc2)C1=O</smiles>

N-(2-(3-hydroxy-2-isopropoxy-4-oxo-3-phenylcyclobut-1-enyl)phenyl)pivalamide (64) At -78

${ }^{\circ} \mathrm{C}$ under $\mathrm{N}_{2}$ atmosphere, $\mathrm{PhLi}(0.7 \mathrm{~mL}, 1.13 \mathrm{mmol}, 1.6 \mathrm{M}$ in diButylether) was added to a solution of 62 (324 mg, $1.03 \mathrm{mmol})$ in THF (17 mL). After stirring for 3 days, the reaction was quenched with $10 \% \mathrm{NH}_{4} \mathrm{Cl}$ in $\mathrm{H}_{2} \mathrm{O}$. It was extracted with ether, dried over $\mathrm{MgSO}_{4}$, then filtered. The solvents were removed under reduced pressure and the residue was purified by column chromatography (hexanes:EtOAc in the order of elution, 98:2, 95:5, 9:1, 85:15) to afford 64 (330 mg, $0.84 \mathrm{mmol}, 82 \%) .{ }^{1} \mathrm{H}$ NMR $(270 \mathrm{MHz}) \delta 9.61(\mathrm{~s}, 1 \mathrm{H}), 8.06(\mathrm{~d}, J=7.7 \mathrm{~Hz}, 1 \mathrm{H}), 7.57$ (dd, $J$ 
$=7.7$ and $1.7 \mathrm{~Hz}, 1 \mathrm{H}), 7.51(\mathrm{dd}, J=7.7$ and $1.2,1 \mathrm{H}), 7.41-7.32(\mathrm{~m}, 4 \mathrm{H}), 7.25(\mathrm{dt}, J=8.4$ and 1.5 $\mathrm{Hz}, 1 \mathrm{H}), 7.06(\mathrm{dt}, J=7.7$ and $1.2 \mathrm{~Hz}, 1 \mathrm{H}), 4.90(\mathrm{sept}, J=6.0 \mathrm{~Hz}, 1 \mathrm{H}), 4.81(\mathrm{br}, 1 \mathrm{H}), 1.47(\mathrm{~d}, J=$ $6.2 \mathrm{~Hz}, 3 \mathrm{H}), 1.23(\mathrm{~s}, 9 \mathrm{H}), 1.05(\mathrm{~d}, J=6.2, \mathrm{~Hz}, 3 \mathrm{H}) ;{ }^{13} \mathrm{C} \mathrm{NMR}(67.5 \mathrm{MHz}) \delta 188.5(+), 181.0(+)$, $178.1(+), 136.2(+), 129.0(-), 128.7(-), 128.6(-), 128.5(-), 125.4(-), 125.3(+), 124.1(-), 123.9(-$ ), $119.0(+), 91.8(+), 80.3(-), 39.9(+), 27.3(-), 22.8(-) 22.4(-)$; IR (neat) 3284, 2982, 1732, 1660, $1575,1387,1083,907,750 \mathrm{~cm}^{-1}$.<smiles>CCCCNc1ccccc1C1=C(OC(C)C)C(OS(C)(=O)=O)(c2ccccc2)C1=O</smiles>

N-(2-(3-Trimethylsilylhydroxy-2-isopropoxy-4-oxo-3-phenylcyclobut-1-enyl)phenyl)pivalamide (65) TMSCl (0.16 mL, $1.25 \mathrm{mmol})$ was added to a mixture of 64 (350 mg, $0.89 \mathrm{mmol}$ ) and DMAP (195 mg, $1.29 \mathrm{mmol}$ ) in DMF (1.5 mL) under $\mathrm{N}_{2}$ atmosphere. After stirring for $12 \mathrm{~h}$ at $\mathrm{rt}$, the reaction was quenched with $\mathrm{H}_{2} \mathrm{O}$ and extracted with ether. The organic portions were dried over $\mathrm{MgSO}_{4}$ and the solvents were removed under reduced pressure. The residue was purified by column chromatography (hexanes:EtOAc in the order of elution, 98:2, 95:5, 9:1) to afford 65 (269, $0.58 \mathrm{mmol}, 65 \%) .{ }^{1} \mathrm{H}$ NMR $(270 \mathrm{MHz}) \delta 9.77(\mathrm{~s}, 1 \mathrm{H}), 8.18(\mathrm{~d}, J=8.4 \mathrm{~Hz}, 1 \mathrm{H}), 7.63(\mathrm{dd}, J=$ 7.9 and $1.5 \mathrm{~Hz}, 1 \mathrm{H}), 7.51-7.29(\mathrm{~m}, 6 \mathrm{H}), 7.12(\mathrm{t}, J=7.7 \mathrm{~Hz}, 1 \mathrm{H}), 4.88($ sept, $J=5.9 \mathrm{~Hz}, 1 \mathrm{H}), 1.45(\mathrm{~d}$, $J=6.2 \mathrm{~Hz}, 3 \mathrm{H}), 1.29(\mathrm{~s}, 9 \mathrm{H}), 0.97(\mathrm{~d}, J=6.2 \mathrm{~Hz}, 3 \mathrm{H})$.<smiles>CC(C)OC1=C(c2ccccc2NC(=O)OCc2ccccc2)C(=O)C1(O)c1ccccc1</smiles> 
tert-Butyl 2-(3-Trimethylsilylhydroxy-2-isopropoxy-4-oxo-3-phenylcyclobut-1-

enyl)phenylcarbamate (66) At $-78^{\circ} \mathrm{C}$ under $\mathrm{N}_{2}$ atmosphere, PhLi $(2.20 \mathrm{~mL}, 3.74 \mathrm{mmol}, 1.7 \mathrm{M}$ in diButylether) was added to a solution of 61 (1.027 g, $3.10 \mathrm{mmol})$ in THF(16 mL). After stirring for $50 \mathrm{~min}, \mathrm{TMSCl}(0.65 \mathrm{~mL}, 5.14 \mathrm{mmol})$ was added via syringe and allowed to stir at $0{ }^{\circ} \mathrm{C}$ for 1.5 h. The reaction was quenched with $10 \% \mathrm{NH}_{4} \mathrm{Cl}$ in $\mathrm{H}_{2} \mathrm{O}$ then extracted with EtOAc, dried over $\mathrm{MgSO}_{4}$, and filtered. The solvents were removed under reduced pressure and the residue was purified by column chromatography (hexanes:EtOAc in the order of elution, 98:2, 95:5, 9:1) to afford 66 (607 mg, $1.26 \mathrm{mmol}, 41 \%) .{ }^{1} \mathrm{H}$ NMR (270 MHz) $\delta 9.26$ (br s, $\left.1 \mathrm{H}\right), 8.05$ (d, J = 8.4 Hz, 1H), $7.68(\mathrm{dd}, J=7.8$ and $1.2 \mathrm{~Hz}, 1 \mathrm{H}), 7.50-7.48(\mathrm{~m}, 1 \mathrm{H}), 7.39-7.29(\mathrm{~m}, 4 \mathrm{H}), 7.06(\mathrm{dt}, J=7.2$ and $1.2 \mathrm{~Hz}, 1 \mathrm{H}), 4.88(\mathrm{sept}, 6.0 \mathrm{~Hz}, 1 \mathrm{H}), 1.51(\mathrm{~s}, 9 \mathrm{H}), 1.44(\mathrm{~d}, J=6.0 \mathrm{~Hz}, 3 \mathrm{H}), 0.99(J=6.0 \mathrm{~Hz}, 3 \mathrm{H})$, 0.28 (s, 9H). ${ }^{13} \mathrm{C}$ NMR (150 MHz) $\delta 187.5$ (C), 180.2 (C), 153.2 (C), 137.5 (C), 137.0 (C), 129.3 $(\mathrm{CH}), 128.6(\mathrm{CH}), 128.6(\mathrm{CH}), 128.2(\mathrm{CH}), 125.6(\mathrm{C}), 125.5(\mathrm{CH}), 122.7(\mathrm{CH}), 121.6(\mathrm{CH}), 119.1(\mathrm{C})$, $93.4(\mathrm{C}), 79.7(\mathrm{C}), 79.4(\mathrm{CH}), 28.3\left(\mathrm{CH}_{3}\right), 22.7\left(\mathrm{CH}_{3}\right), 22.4\left(\mathrm{CH}_{3}\right), 1.12\left(\mathrm{CH}_{3}\right)$, IR (neat) 2979, 1726, 1251, 1148, 1086, 839 and $747 \mathrm{~cm}^{-1}$, HRMS Calcd for $\mathrm{C}_{27} \mathrm{H}_{36} \mathrm{NO}_{5}\left(\mathrm{M}+\mathrm{H}^{+}\right):$: 482.2357, Found 482.2357 .<smiles></smiles>

\section{3-(2-trimethylsilylhydroxy-1-isopropoxy-2-phenylethylidene)-1-(pivaloyl)indolin-2-one (67)}

65 (230 mg, $0.49 \mathrm{mmol}$ ) was dissolved in xylenes $(12 \mathrm{~mL})$ and then transferred to a pressure tube. The reaction vessel was sealed then submerged in a $150{ }^{\circ} \mathrm{C}$ oil bath for $4 \mathrm{~h}$. Then solvents were removed under reduced pressure. The residue was purified by column 
chromatography (hexane:EtOAc, 98:2, 95:5, 9:1) to afford the oxindole $67(100 \mathrm{mg}, 0.21 \mathrm{mmol}$, 43\%). ${ }^{1} \mathrm{H}$ NMR $(270 \mathrm{MHz}) \delta 7.85(\mathrm{dd}, J=7.7$ and $1.8 \mathrm{~Hz}, 1 \mathrm{H}), 7.57(\mathrm{~s}, 1 \mathrm{H}), 7.37-7.15(\mathrm{~m}, 5 \mathrm{H}), 7.12$ (dt, $J=7.9$ and $1.5 \mathrm{~Hz}, 1 \mathrm{H}), 7.02(\mathrm{dt}, J=7.7$ and $1.2 \mathrm{~Hz}, 1 \mathrm{H}), 5.33(\mathrm{sept}, J=6.0 \mathrm{~Hz}, 1 \mathrm{H}), 1.38(\mathrm{~s}$, $9 \mathrm{H}), 1.28(\mathrm{~d}, J=6.0 \mathrm{~Hz}, 3 \mathrm{H}), 0.66(\mathrm{~d}, J=6.2 \mathrm{~Hz}, 3 \mathrm{H}), 0.15\left(\mathrm{~s},(\mathrm{H}) ;{ }^{13} \mathrm{C} \mathrm{NMR}(67.5 \mathrm{MHz}) \delta 183.8\right.$, $170.8,167.7,139.8,137.1,128.5,127.1,126.7,124.7,124.3,123.4,112.5,105.9,75.1,67.7$, $43.6,31.6,27.1,23.1,22.5,-0.13$.<smiles>CC(C)OC(=C1C(=O)N(C(C)(C)C)c2ccccc21)C(OC(C)(C)C)c1ccccc1</smiles>

tert-Butyl 3-(2-Trimethylsilylhydroxy-1-isopropoxy-2-phenylethylidene)-2-oxoindoline-1carboxylate (68) Compound 66 (310 $\mathrm{mg}, 0.64 \mathrm{mmol}$ ) was dissolved in xylenes $(30 \mathrm{~mL})$ and transferred to a pressure tube. The reaction vessel was sealed then submerged in a $160^{\circ} \mathrm{C}$ oil bath and was stirred for $12 \mathrm{~h}$. Then the solvent was removed under reduced pressure. The residue was purified by column chromatography (hexanes:EtOAc, 9:1) to afford the oxindole 68 (242 mg, $0.50 \mathrm{mmol}, 78 \%) .{ }^{1} \mathrm{H}$ NMR $(270 \mathrm{MHz}) \delta 7.97(\mathrm{dd}, J=7.4$ and $1.0 \mathrm{~Hz}, 1 \mathrm{H}), 7.78(\mathrm{~d}, J=8.2$ $\mathrm{Hz}, 1 \mathrm{H}), 7.70(\mathrm{~s}, 1 \mathrm{H}), 7.43-7.21(\mathrm{~m}, 5 \mathrm{H}), 7.13(\mathrm{dt}, J=7.7$ and $1.0 \mathrm{~Hz}, 1 \mathrm{H}), 5.32(\mathrm{sept}, J=6.0 \mathrm{~Hz}$, $1 \mathrm{H}), 1.67(\mathrm{~s}, 9 \mathrm{H}), 1.37(\mathrm{~d}, J=6.0 \mathrm{~Hz}, 3 \mathrm{H}), 0.74(\mathrm{~d}, J=6.0 \mathrm{~Hz}, 3 \mathrm{H}), 0.24(\mathrm{~s}, 9 \mathrm{H}) ;{ }^{13} \mathrm{C} \mathrm{NMR}(150 \mathrm{MHz})$ $\delta 171(\mathrm{C}), 167.1$ (C), 149.5 (C), 140.0 (C), 136.0 (C), 128.4 (CH), 127.0 (CH), 126.7 (CH), 124.9 (CH), $123.7(\mathrm{C}), 123.6(\mathrm{CH}), 113.8(\mathrm{CH}), 106.0(\mathrm{C}), 83.8(\mathrm{C}), 75.2(\mathrm{CH}), 67.9(\mathrm{CH}), 28.2\left(\mathrm{CH}_{3}\right), 23.1$ $\left(\mathrm{CH}_{3}\right), 22.6\left(\mathrm{CH}_{3}\right),-0.15\left(\mathrm{CH}_{3}\right) ; \mathrm{IR}$ (neat) 2976, 1728, 1610, 1087, $746 \mathrm{~cm}^{-1}$. 

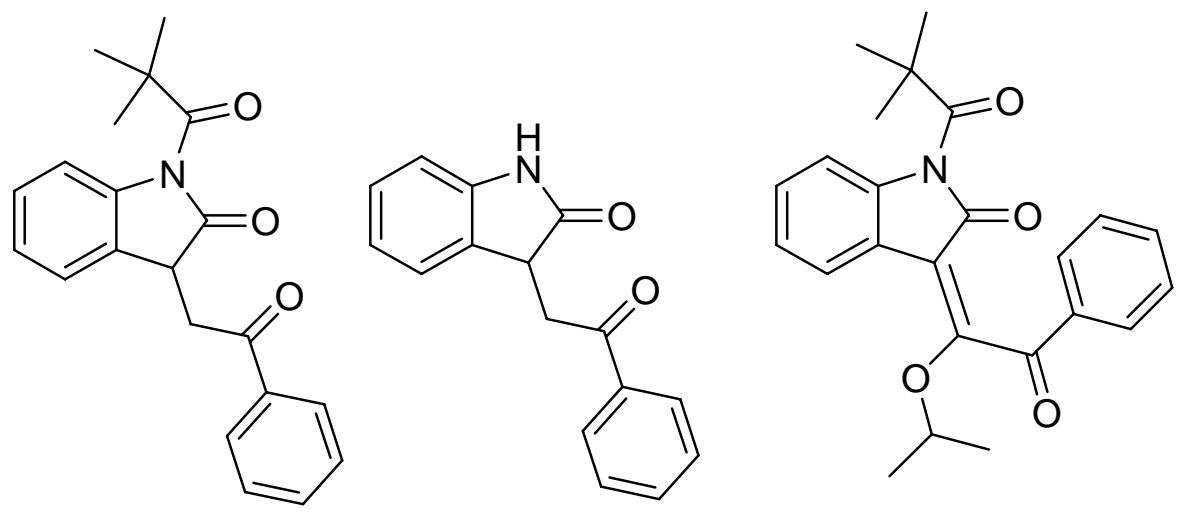

3-(2-phenyl-ethan-2-one)-1-(pivaloyl)indolin-2-one (74) and 3-(2-phenyl-ethan-2-one)-indolin2-one (75) and 3-(1-isopropoxy-2-oxo-2-phenylethylidene)-1-(pivaloyl)indolin-2-one (76)

Hydroxycyclobutenone 64 (1.02 g, $2.59 \mathrm{mmol})$ was dissolved in xylenes $(20 \mathrm{~mL})$ and transferred to a pressure tube. The pressure tube was sealed then submerged in $175^{\circ} \mathrm{C}$ oil bath and was stirred for $5 \mathrm{~h}$. Then the solvents were removed under reduced pressure. The residue was purified by column chromatography (hexanes:EtOAc in the order of elution, 95:5, 9:1, 85:15, $8: 2)$ to afford 75 (90 mg, $0.27 \mathrm{mmol}, 10 \%), 74(70 \mathrm{mg}, 0.28 \mathrm{mmol}, 11 \%)$ and 76 (94 mg, 0.24 mmol, 9\%). .(74) ${ }^{1} \mathrm{H}$ NMR (270 MHz) $\delta 7.97(\mathrm{~d}, J=7.2 \mathrm{~Hz}, 1 \mathrm{H}), 7.61-7.43(\mathrm{~m}, 5 \mathrm{H}), 7.25(\mathrm{t}, J=8.7$ $\mathrm{Hz}, 1 \mathrm{H}), 7.20(\mathrm{~d}, J=7.4 \mathrm{~Hz}, 1 \mathrm{H}), 7.06(\mathrm{t}, J=7.4 \mathrm{~Hz}, 1 \mathrm{H}), 4.19(\mathrm{dd}, J=7.7$ and $3.0 \mathrm{~Hz}, 1 \mathrm{H}), 3.85(\mathrm{dd}$, $J=18.3$ and $3.4 \mathrm{~Hz}, 1 \mathrm{H}), 3.55(\mathrm{dd}, J=18.3$ and $7.7 \mathrm{~Hz}, 1 \mathrm{H}), 1.46(\mathrm{~s}, 9 \mathrm{H}) ;{ }^{13} \mathrm{CNMR}(67.5 \mathrm{MHz}) \delta$ $196.1(+), 182.4(+), 176.9(+), 141.4(+), 136.0(+), 133.5(-), 128.9(+), 128.6(-), 128.1(-), 124.1$ $(-), 123.7(-), 114.2(-), 109.9(-), 43.3(+), 41.8(-), 39.9(+), 26.8(-) ;(75){ }^{1} \mathrm{H}$ NMR $(270 \mathrm{MHz}) \delta$ $8.85(\mathrm{~s}, 9 \mathrm{H}), 7.99(\mathrm{~d}, J=7.4 \mathrm{~Hz}, 2 \mathrm{H}), 7.59(\mathrm{t}, J=7.2 \mathrm{~Hz}, 1 \mathrm{H}), 7.47(\mathrm{t}, J=7.4 \mathrm{~Hz}, 2 \mathrm{H}), 7.20(\mathrm{t}, J=8.2$ $\mathrm{Hz}, 2 \mathrm{H}), 6.98(\mathrm{~d}, J=7.7 \mathrm{~Hz}, 1 \mathrm{H}), 6.92(\mathrm{~d}, J=7.7 \mathrm{~Hz}, 1 \mathrm{H}), 4.11(\mathrm{dd}, J=8.6$ and $3.2 \mathrm{~Hz}, 1 \mathrm{H}), 3.84$ (dd, $J=18.3$ and $3.2 \mathrm{~Hz}, 1 \mathrm{H}), 3.47(\mathrm{dd}, J=18.3$ and $8.6 \mathrm{~Hz}, 1 \mathrm{H}){ }^{13} \mathrm{C} \mathrm{NMR}(67.5 \mathrm{MHz}) \delta 196.8(+)$, $180.3(+), 141.5(+), 136.2(+), 133.5(-), 129.6(+), 128.7(-), 128.1(-), 128.0(-), 124.5(-), 122.4(-$ ), $109.8(-), 41.6(-), 39.7(+)$; HRMS Calcd for $\mathrm{C}_{16} \mathrm{H}_{14} \mathrm{NO}_{2}\left(\mathrm{M}+\mathrm{H}^{+}\right)$: 252.1019 Found: 252.1018 (76) 
${ }^{1} \mathrm{H}$ NMR $(270 \mathrm{MHz}) \delta 8.05(\mathrm{dd}, J=8.2$ and $1.2 \mathrm{~Hz}, 2 \mathrm{H}), 7.88(\mathrm{dd}, J=7.2$ and $1.2 \mathrm{~Hz}, 1 \mathrm{H}), 7.68-7.49$ (m, 4H), $7.26(\mathrm{dt}, J=7.4$ and $1.5 \mathrm{~Hz}, 1 \mathrm{H}), 7.17(\mathrm{dt}, J=7.7$ and $.2 \mathrm{~Hz}, 1 \mathrm{H}), 4.51$ (sept $J=6.2 \mathrm{~Hz}$, 1H), $1.38-1.36(\mathrm{~m}, 6 \mathrm{H}), 1.28(\mathrm{~s}, 9 \mathrm{H}) ;{ }^{13} \mathrm{C} \mathrm{NMR}(67.5 \mathrm{mHz}) \delta 191.0(+), 182.3(+), 166.3(+), 160.9$ $(+), 139.1(+), 135.0(+), 134.5(-), 129.0(-), 127.7(-), 123.8(-), 123.1(-), 122.7(+), 113.8(-)$, $109.0(-), 107(+), 75.6(-), 43.1(+), 26.7(-), 23.2(-)$.

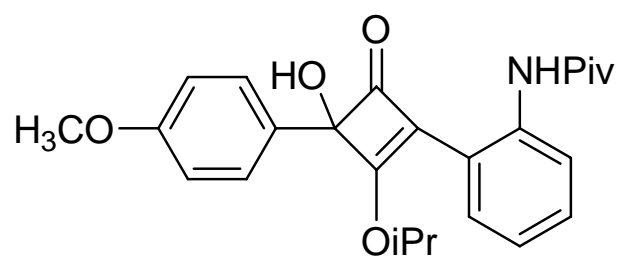

N-(2-(3-hydroxy-2-isopropoxy-3-(4-methoxyphenyl)-4-oxocyclobut-1-enyl)phenyl)pivalamide (77) 4-anisylmagnesium bromide $(3.0 \mathrm{~mL}, 1.2 \mathrm{mmol}, 0.4 \mathrm{M}$ in THF) was added to 62 (304 mg, $0.97 \mathrm{mmol}$ ) in THF (35 mL) under $\mathrm{N}_{2}$ atmosphere at $-78^{\circ} \mathrm{C}$. After stirring for 2 days, it was quenched with $10 \% \mathrm{NH}_{4} \mathrm{Cl}$ in $\mathrm{H}_{2} \mathrm{O}$, washed with brine, and dried over $\mathrm{MgSO}_{4}$. The mixture was filtered then the solvents were removed under reduced pressure. The residue was purified by column chromatography (hexanes:EtOAc in the order of elution, 9:1, 85:15) to afford 77 (303 $\mathrm{mg}, 0.72 \mathrm{mmol}, 74 \%)$ as a colorless oil. ${ }^{1} \mathrm{H} \mathrm{NMR}(600 \mathrm{MHz}) \delta 9.61(\mathrm{~s}, 1 \mathrm{H}), 8.11(\mathrm{~d}, J=7.8 \mathrm{~Hz}, 1 \mathrm{H})$, $7.61(\mathrm{dd}, J=7.8$ and $1.2 \mathrm{~Hz}, 1 \mathrm{H}), 7.44(\mathrm{~d}, J=9.0,2 \mathrm{H}), 7.30(, \mathrm{dt}, J=7.2$ and $1.2 \mathrm{~Hz}, 1 \mathrm{H}), 7.10(\mathrm{dt}, J$ $=7.2$ and $1.2 \mathrm{~Hz}, 1 \mathrm{H}), 6.92(\mathrm{~d}, J=9.0 \mathrm{~Hz}, 2 \mathrm{H}), 4.89(\mathrm{sept}, J=6.0 \mathrm{~Hz}, 1 \mathrm{H}), 3.82(\mathrm{~s}, 3 \mathrm{H}), 1.48(\mathrm{~d}, J=$ $6.0 \mathrm{~Hz}, 3 \mathrm{H}), 1.27(\mathrm{~s}, 9 \mathrm{H}), 1.10(\mathrm{~d}, J=6.0 \mathrm{~Hz}, 3 \mathrm{H}) ;{ }^{13} \mathrm{C}$ NMR (150 MHZ) $\delta 188.5(\mathrm{C}), 180.9(\mathrm{C})$, 178.0, (C), 159.9 (C), $136.5(\mathrm{C}), 129.1(\mathrm{CH}), 128.6(\mathrm{CH}), 127.9(\mathrm{CH}), 126.7(\mathrm{CH}), 125.5(\mathrm{C}), 124.2$ (CH), $123.9(\mathrm{CH}), 119.6(\mathrm{C}), 114.3(\mathrm{CH}), 91.7(\mathrm{C}), 80.2(\mathrm{CH}), 55.3\left(\mathrm{CH}_{3}\right), 39.9(\mathrm{C}), 27.3\left(\mathrm{CH}_{3}\right), 22.9$ $\left(\mathrm{CH}_{3}\right), 22.5\left(\mathrm{CH}_{3}\right) ; \mathrm{IR}$ (neat) 3286, 2965, 1736, 1577, 1386, 1250, 1099, $753 \mathrm{~cm}^{-1}$, HRMS calcd for $\mathrm{C}_{25} \mathrm{H}_{30} \mathrm{NO}_{5}\left(\mathrm{M}+\mathrm{H}^{+}\right):$424.2118, Found 424.2124. 


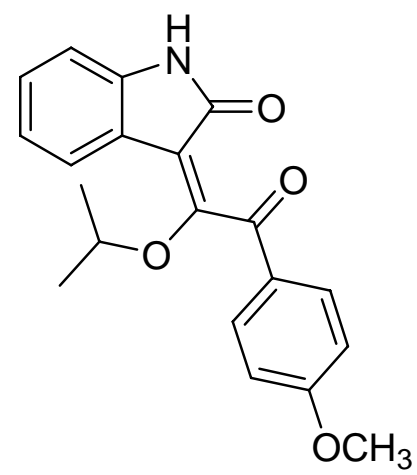

\section{3-(1-isopropoxy-2-(4-methoxyphenyl)-2-oxoethylidene)indolin-2-one (78)}

Hydroxycyclobutenone 77 (105 mg, $0.25 \mathrm{mmol})$ was dissolved in xylenes $(5 \mathrm{~mL})$ and transferred to a pressure tube. The reaction vessel was sealed then submerged in a $120^{\circ} \mathrm{C}$ oil bath. After 5 $\mathrm{h}$ the solvents were removed under reduced pressure. The residue was purified by column chromatography (hexanes:EtOAc, 9:1) to afford 78 (46 mg, $0.14 \mathrm{mmol}, 56 \%$ ) as a orange oil. ${ }^{1} \mathrm{H}$ $\operatorname{NMR}(600 \mathrm{MHz}) \delta 8.47$ (br s, 1H), $8.02(\mathrm{~d}, J=9.0,2 \mathrm{H}), 7.76(\mathrm{~d}, J=7.8 \mathrm{~Hz}, 1 \mathrm{H}), 7.13(\mathrm{dt}, J=7.8$ and $1.2 \mathrm{~Hz}, 1 \mathrm{H}), 7.01(\mathrm{dt}, J=7.2$ and $1.2 \mathrm{~Hz}, 1 \mathrm{H}), 6.94(\mathrm{~d}, J=9.0 \mathrm{~Hz}, 2 \mathrm{H}), 6.67(\mathrm{~d}, J=7.2 \mathrm{~Hz}, 1 \mathrm{H})$, 4.51 (sept, J = 6.0 Hz, 1H), $3.85(\mathrm{~s}, 3 \mathrm{H}), 1.41(\mathrm{br} \mathrm{d}, J=6.0 \mathrm{~Hz}, 3 \mathrm{H}), 1.31(\mathrm{br} \mathrm{d}, J=5.4 \mathrm{~Hz}, \mathrm{~Hz}, 3 \mathrm{H})$;

${ }^{13} \mathrm{C}$ NMR (150 MHz) $\delta 189.6$ (C), 169.2(C), 164.6 (C), 160.5 (C), 139.4 (C), 131.5 (CH), 128.7 (C), $127.4(\mathrm{CH}), 123.4(\mathrm{CH}), 122.5(\mathrm{C}), 121.6(\mathrm{CH}), 114.3(\mathrm{CH}), 109.4(\mathrm{CH}), 108.5(\mathrm{C}), 75.3(\mathrm{CH}), 55.5$ $\left(\mathrm{CH}_{3}\right), 23.3\left(\mathrm{CH}_{3}\right)$; IR (neat) 2980, 1694, 1594, 1464, 1257, 1097, 811, $732 \mathrm{~cm}^{-1}$. HRMS Cald for $\mathrm{C}_{20} \mathrm{H}_{20} \mathrm{NO}_{4}\left(\mathrm{M}+\mathrm{H}^{+}\right): 338.1387$. Found: 338.1390 .<smiles>CC(C)Oc1c(-c2ccccc2[N+](=O)[O-])c(=O)c1=O</smiles>

3-isopropoxy-4-(2-nitrophenyl)cyclobut-3-ene-1,2-dione (81) TFAA was added to a solution of 39 and pyridine in ether under $\mathrm{N}_{2}$ atmosphere at $0{ }^{\circ} \mathrm{C}$. After stirring for $1 \mathrm{~h}$, the reaction was 
quenched with $\mathrm{H}_{2} \mathrm{O}$ and extracted with EtOAc. The combined organic portions were dried over $\mathrm{MgSO}_{4}$, filtered and the solvents were removed under reduced atmosphere. Ther residue was purified by column chromatography (hexanes:EtOAc, 7:3) to afford the cyclobutenedione $\mathbf{8 1}$ (2.275 g, $8.71 \mathrm{mmol}, 95 \%){ }^{1} \mathrm{H}$ NMR $(270 \mathrm{MHz}) \delta 8.04(\mathrm{~d}, J=7.7 \mathrm{~Hz}, 1 \mathrm{H}), 7.98(\mathrm{~d}, J=7.4 \mathrm{~Hz}, 1 \mathrm{H})$, $7.76(\mathrm{t}, J=7.4 \mathrm{~Hz}, 1 \mathrm{H}), 7.66(\mathrm{t}, J=7.4 \mathrm{~Hz}, 1 \mathrm{H}), 5.59(\operatorname{sept}, J=6.2 \mathrm{~Hz}, 1 \mathrm{H}), 1.51(\mathrm{~d}, J=6.0 \mathrm{~Hz}, 6 \mathrm{H})$; ${ }^{13} \mathrm{C}$ NMR $(67.5 \mathrm{MHz}) \delta 194.7,192.3,190.3,170.9,147.0,133.3,131.9,129.2,125.0,121.2,81.3$, 22.8 .

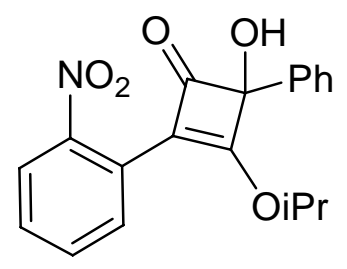

\section{4-hydroxy-3-isopropoxy-2-(2-nitrophenyl)-4-phenylcyclobut-2-enone (82) Phenylmagnesium} chloride (0.7 mL, $1.44 \mathrm{mmol}, 2.05 \mathrm{M}$ in THF) was added to 81 (305 mg, $1.17 \mathrm{mmol}$ ) in THF (6 mL) under $\mathrm{N}_{2}$ atmosphere at $-78{ }^{\circ} \mathrm{C}$. After stirring for $5 \mathrm{~h}$, the reaction was quenched with $10 \%$ $\mathrm{NH}_{4} \mathrm{Cl}$ in $\mathrm{H}_{2} \mathrm{O}$ and extracted with EtOAc. The combined organic portions were dried over $\mathrm{MgSO}_{4}$, filtered, and then the solvents were removed under reduced pressure to afford $\mathbf{8 2}$ (391 $\mathrm{mg}, 1.15 \mathrm{mmol}$, 98\%) without further purification because of its sensitivity to chromatographic methods. ${ }^{1} \mathrm{H}$ NMR $(270 \mathrm{MHz}) \delta 7.93(\mathrm{~d}, J=8.2 \mathrm{~Hz}, 1 \mathrm{H}), 7.85(\mathrm{~d}, J=7.9 \mathrm{~Hz}, 1 \mathrm{H}), 7.67-7.58(\mathrm{~m}$, $3 \mathrm{H}), 7.49-7.35(\mathrm{~m}, 4 \mathrm{H}), 4.80$ (sept, $J=6.2 \mathrm{~Hz}, 1 \mathrm{H}$ ), 3.84 (br s, $1 \mathrm{H}), 1.40$ (d, J = $6.2 \mathrm{~Hz}, 3 \mathrm{H}), 1.09$ (d, J $6.2 \mathrm{~Hz}, 3 \mathrm{H})$. 


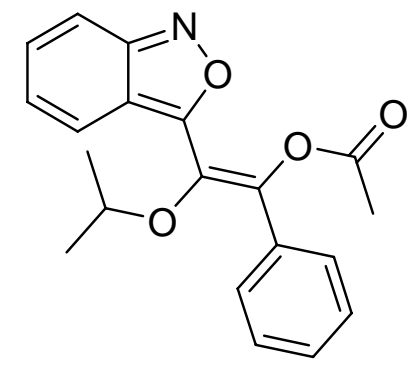

2-(benzo[c]isoxazol-3-yl)-2-isopropoxy-1-phenylvinyl acetate (85). To 81 (700 mg, $2.68 \mathrm{mmol})$ in THF $(20 \mathrm{~mL})$ was added $\mathrm{PhMgCl}\left(1.8 \mathrm{~mL}, 3.6 \mathrm{mmol}, 2.0 \mathrm{M}\right.$ in THF) at $-78^{\circ} \mathrm{C}$. After stirring for 1 $\mathrm{h}$, the reaction was warmed to $-50{ }^{\circ} \mathrm{C}$ and was stirred for $2 \mathrm{~h}$. Then $\mathrm{Ac}_{2} \mathrm{O}(0.6 \mathrm{~mL}, 6.38 \mathrm{mmol})$ was added via syringe. The reaction mixture warmed to rt then $10 \% \mathrm{NH}_{4} \mathrm{Cl}$ in $\mathrm{H}_{2} \mathrm{O}$ was added and was extracted with EtOAc. The combined organic portions were dried over $\mathrm{MgSO}_{4}$ then filtered and then the solvents were removed under reduced pressure. The residue was then dissolved in xylenes $(20 \mathrm{~mL})$ and transferred to a pressure tube. The reaction vessel was sealed then submerged in a $160{ }^{\circ} \mathrm{C}$ oil bath. After stirring for $2 \mathrm{~h}$, then solvents were removed under reduced pressure. The residue was purified by column chromatography (hexanes:EtOAc in the order of elution, 95:5, 9:1) to afford $85(450 \mathrm{mg}, 0.13 \mathrm{mmol} 50 \%)^{1} \mathrm{H}$ NMR $(600 \mathrm{MHz}) \delta 7.50(\mathrm{~d}, J$ $=9.0 \mathrm{~Hz}, 1 \mathrm{H}), 7.23-7.15(\mathrm{~m}, 8 \mathrm{H}), 6.82(\mathrm{dd}, J=8.4$ and $6.0 \mathrm{~Hz}, 1 \mathrm{H}), 3.94(\mathrm{sept}, J=6.0 \mathrm{~Hz}, 1 \mathrm{H}), 2.29$ (s, 3H), $1.25(\mathrm{~d}, J=6.6 \mathrm{~Hz}, 6 \mathrm{H}) ;{ }^{13} \mathrm{C}$ NMR (150 MHz) $\delta 168.5$ (C), 160.1 (C), 157.3 (C), $141.2(\mathrm{C})$, $133.1(\mathrm{C}), 133.1(\mathrm{C}), 130.7(\mathrm{CH}), 128.8(\mathrm{CH}), 128.2(\mathrm{CH}), 128.1(\mathrm{CH}), 124.7(\mathrm{CH}), 120.0(\mathrm{CH}), 117.4$ (C), $115.1\left(\mathrm{CH}, 74.0(\mathrm{CH})\right.$. HRMS Calcd for $\mathrm{C}_{20} \mathrm{H}_{20} \mathrm{NO}_{4}\left(\mathrm{M}+\mathrm{H}^{+}\right)$: 338.1387. Found: 338.1389.<smiles>CC(C)Oc1c(-c2ccccc2O)c(=O)c1=O</smiles> 
3-(2-hydroxyphenyl)-4-isopropoxycyclobut-3-ene-1,2-dione (93) At -10 ${ }^{\circ} \mathrm{C}, 2$-bromophenol $(0.5$ $\mathrm{mL}, 4.2 \mathrm{mmol}$ ) was added to a solution of $n B$ BuLi $(4.0 \mathrm{~mL}, 5.4 \mathrm{mmol}, 2.7 \mathrm{M}$ in hexanes) in ether $(95 \mathrm{~mL})$ under $\mathrm{N}_{2}$ atmosphere. After stirring for $3.5 \mathrm{~h}$, the mixture was cooled to $-78{ }^{\circ} \mathrm{C}$ then diisopropyl squarate $(916 \mathrm{mg}, 4.6 \mathrm{mmol})$ in THF $(5 \mathrm{~mL})$ was added via cannula. After stirring for $12 \mathrm{~h}$, the mixture was quenched with $10 \% \mathrm{NH}_{4} \mathrm{Cl}$ and extracted with EtOAc. The combined organic portions were washed with brine and the solvents were removed under reduced pressure. TFAA $(0.75 \mathrm{~mL}, 5.3 \mathrm{mmol})$ was added to a residue and pyridine $(0.46 \mathrm{~mL})$ in $\mathrm{Et}_{2} \mathrm{O}(55$ $\mathrm{mL}$ ) at $-10{ }^{\circ} \mathrm{C}$. After stirring for $3 \mathrm{~h}$, the reaction was quenched with the addition of $\mathrm{H}_{2} \mathrm{O}$, extracted with ether, washed with brine and dried over $\mathrm{MgSO}_{4}$. The mixture was filtered and the solvents were removed under reduced pressure. The residue was purified via column chromatography (hexanes:EtOAc, 9:1) to afford 93 (479 mg, $2.06 \mathrm{mmol}, 48 \%$ ) as a colorless oil. ${ }^{1} \mathrm{H}$ NMR $(600 \mathrm{MHz}) \delta 9.91(\mathrm{~s}, 1 \mathrm{H}), 7.67(\mathrm{dd}, J=7.8$ and $1.8 \mathrm{~Hz}, 1 \mathrm{H}), 7.41(\mathrm{dt}, J=7.8$ and $1.8 \mathrm{~Hz}$, 1H), $7.00(\mathrm{dd}, J=8.4$ and $0.6 \mathrm{~Hz}, 1 \mathrm{H}), 6.94(\mathrm{dt}, J=7.2$ and $0.6 \mathrm{~Hz}, 1 \mathrm{H}), 5.68(\mathrm{sept}, J=6.0 \mathrm{~Hz}, 1 \mathrm{H})$, $1.59(\mathrm{~d}, J=6.0 \mathrm{~Hz}, 6 \mathrm{H}) ;{ }^{13} \mathrm{C}$ NMR $(150 \mathrm{MHz}) \delta 196.7$ (C), 193.7 (C), 186.0 (C), 173.0 (C), 159.0 (C), $135.7(\mathrm{CH}), 128.8(\mathrm{CH}), 120.2(\mathrm{CH}), 119.0(\mathrm{CH}), 114.7(\mathrm{C}), 81.5(\mathrm{CH}), 23.0\left(\mathrm{CH}_{3}\right), 23.0\left(\mathrm{CH}_{3}\right)$; IR (neat) $3163,2917,1776,1724,1554,1391,1089,768 \mathrm{~cm}^{-1}$; HRMS Calcd for $\mathrm{C}_{13} \mathrm{H}_{13} \mathrm{O}_{4}\left(\mathrm{M}+\mathrm{H}^{+}\right)$: 233.0808 Found: 233.0809.

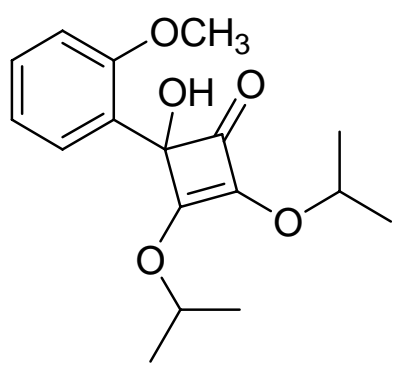


4-hydroxy-2,3-diisopropoxy-4-(2-methoxyphenyl)cyclobut-2-enone (94) At -80 ${ }^{\circ} \mathrm{C}, \mathrm{nBuLi}(1.85$

$\mathrm{mL}, 5.00 \mathrm{mmol}, 2.7 \mathrm{M}$ in ) was added to 2-bromoanisole (0.50 mL, $4.21 \mathrm{mmol})$ in ether $(90 \mathrm{~mL})$. After $1.5 \mathrm{~h}$, squarate $(970 \mathrm{mg}, 4.89 \mathrm{mmol})$ in THF $(5 \mathrm{~mL})$ was added via cannula. After stirring for $12 \mathrm{~h}$, the reaction was quenched with $10 \% \mathrm{NH}_{4} \mathrm{CL}$ in $\mathrm{H}_{2} \mathrm{O}$ and extracted with EtOAc. The combined organic portions were dried over $\mathrm{MgSO}_{4}$, filtered, and solvents were removed under reduced pressure. The residue was purified by column chromatography (hexanes:EtOAc in the order of elution, 9:1, 85:15) to afford 94 (1.02 g, $3.32 \mathrm{mmol}, 79 \%)$ as a yellow oil. ${ }^{1} \mathrm{H}$ NMR (270 $M H z) \delta 7.31-7.28(m, 2 H), 6.99-6.93(m, 2 H), 4.97(s, 1 H), 4.92($ sept, $J=6.2 \mathrm{~Hz}, 2 \mathrm{H}), 3.93(\mathrm{~s}, 3 \mathrm{H})$, $1.45(\mathrm{~d}, J=6.2 \mathrm{~Hz}, 6 \mathrm{H}), 1.40(\mathrm{~d}, J=6.2 \mathrm{~Hz}, 6 \mathrm{H}), 1.32(\mathrm{~d}, J=6.2 \mathrm{~Hz}, 6 \mathrm{H}), 1.27(\mathrm{~d}, J=6.2 \mathrm{~Hz}, 6 \mathrm{H})$; ${ }^{13} \mathrm{C}$ NMR (67.5 MHz) $\delta 184.1(+), 164.1(+), 157.6(+), 132.8(+), 129.6(-), 127.4(-), 125.8(+)$, $121.3(-), 112.1(-), 88.3(+), 73.4(-), 56.4(-), 27.8(-)$; IR (neat) 3307, 1747, 1589, 1488, 1386, $1253,1083,760 \mathrm{~cm}^{-1}$.<smiles>COc1ccccc1-c1c(OC(C)C)c(=O)c1=O</smiles>

3-isopropoxy-4-(2-methoxyphenyl)cyclobut-3-ene-1,2-dione (96) At -10 ${ }^{\circ} \mathrm{C}$, 2-bromoanisole $(0.5 \mathrm{~mL}, 4.2 \mathrm{mmol})$ was added to a solution of $n B u L i(2.0 \mathrm{~mL}, 5.4 \mathrm{mmol}, 2.7 \mathrm{M}$ in hexanes) in ether $\left(80 \mathrm{~mL}\right.$ ) under $\mathrm{N}_{2}$ atmosphere. After stirring for $2 \mathrm{~h}$, the reation was cooled to $-78^{\circ} \mathrm{C}$ then diisopropyl squarate $(888 \mathrm{mg}, 4.42 \mathrm{mmol})$ in THF $(5 \mathrm{~mL})$ was added via cannula. After stirring for 2 days, the mixture was quenched with $10 \% \mathrm{NH}_{4} \mathrm{Cl}$ and extracted with EtOAc. The combined organic portions were washed with brine, dried over $\mathrm{MgSO}_{4}$, filtered, and then solvents were removed under reduced pressure. TFAA $(0.73 \mathrm{~mL}, 5.2 \mathrm{mmol})$ was added the reaction residue 
and pyridine $(0.44 \mathrm{~mL})$ in $\mathrm{Et}_{2} \mathrm{O}(55 \mathrm{~mL})$ at $-10^{\circ} \mathrm{C}$. After stirring for $3 \mathrm{~h}$, the reaction was quenched with $\mathrm{H}_{2} \mathrm{O}$ and extracted with ether. The combined organic portions were washed with brine, dried over $\mathrm{MgSO}_{4}$, filtered, and concentrated under reduced pressure. The residue was purified by column chromatography (hexanes:EtOAc in the order of elution, 95:5, 9:1) to afford 96 (815 mg, $3.30 \mathrm{mmol}, 79 \%)$ as a yellow solid: $\mathrm{mp}=79-81{ }^{\circ} \mathrm{C} ;{ }^{1} \mathrm{H} \mathrm{NMR}(600 \mathrm{MHz}) \delta 8.04$ (dd, $J=7.8$ and $1.6 \mathrm{~Hz}, 1 \mathrm{H}$ ), $7.48(\mathrm{dt}, J=7.8$ and $1.8 \mathrm{~Hz}, 1 \mathrm{H}$ ), $7.05(\mathrm{dt}, J=7.8$ and $1.2 \mathrm{~Hz}, 1 \mathrm{H}$ ), $6.96(\mathrm{~d}, J=7.8 \mathrm{~Hz}, 1 \mathrm{H}), 5.64(\mathrm{sept}, J=6.0 \mathrm{~Hz}, 1 \mathrm{H}), 3.90(\mathrm{~s}, 3 \mathrm{H}), 1.51(\mathrm{~d}, J=6.0 \mathrm{~Hz}, 6 \mathrm{H}) ;{ }^{13} \mathrm{C} \mathrm{NMR}$ (150 MHz) ס 193.5 (C), 193.4 (C), 192.5 (C), 173.4 (C), 157.3 (C), 134.0 (CH), 129.4 (CH), 120.7 (CH), $117.6(\mathrm{C}), 111.4(\mathrm{CH}), 78.9(\mathrm{CH}), 55.4\left(\mathrm{CH}_{3}\right), 23.0\left(\mathrm{CH}_{3}\right), 23.0\left(\mathrm{CH}_{3}\right) ; \mathrm{IR}$ (neat) 2976, 1776, 1736, 1571, 1389, 1098, $1027 \mathrm{~cm}^{-1}$. HRMS Calcd for $\mathrm{C}_{14} \mathrm{H}_{15} \mathrm{O}_{4}\left(\mathrm{M}+\mathrm{H}^{+}\right): 247.0965$ Found: 247.0964 .<smiles>O=C1C(c2ccccc2O)=C(C(F)(F)F)C1(O)c1ccccc1</smiles>

4-hydroxy-2-(2-hydroxyphenyl)-3-isopropoxy-4-phenylcyclobut-2-enone (97) To a solution of cyclobutendione 93 (150 mg, $0.65 \mathrm{mmol}$ ) in THF ( $25 \mathrm{~mL}$ ) under $\mathrm{N}_{2}$ atmosphere, was added PhLi (0.90 mL, $1.35 \mathrm{mmol}, 1.5 \mathrm{M}$ in diButylether) at $-78^{\circ} \mathrm{C}$. After stirring for $24 \mathrm{~h}$, the reaction was quenched with $10 \% \mathrm{NH}_{4} \mathrm{Cl}$ in $\mathrm{H}_{2} \mathrm{O}$, extracted with ether and washed with brine. The combined organic portions were dried over $\mathrm{MgSO}_{4}$, filtered and solvents were removed under reduced pressure. The residue was purified by column chromatography (hexanes:EtOAc, 9:1) to afford the desired alcohol 96 (131 mg, $0.42 \mathrm{mmol}, 66 \%) .{ }^{1} \mathrm{H}$ NMR (600 MHz) $\delta 9.47$ (br s, 1H), 7.57 (dd, $J=7.8$ and $1.8 \mathrm{~Hz}, 1 \mathrm{H}), 7.52-7.50(\mathrm{~m}, 2 \mathrm{H}), 7.39-7.36(\mathrm{~m}, 2 \mathrm{H}), 7.34-7.31(\mathrm{~m}, 1 \mathrm{H}), 7.19(\mathrm{dt}, J=7.8$ 
and $1.8 \mathrm{~Hz}, 1 \mathrm{H}), 6.89(\mathrm{dd}, J=8.4$ and $1.2,1 \mathrm{H}), 6.85(\mathrm{dt}, J=7.8$ and $1.2 \mathrm{~Hz}, 1 \mathrm{H}), 4.88$ (sept, $J=6.0$ $\mathrm{Hz}, 1 \mathrm{H}), 1.47(\mathrm{~d}, J=6.0 \mathrm{~Hz}, 3 \mathrm{H}), 1.08(\mathrm{~d}, J=6.0 \mathrm{~Hz}, 3 \mathrm{H}) ;{ }^{13} \mathrm{C} \mathrm{NMR}(150 \mathrm{MHz}) \delta 189.9(\mathrm{C}), 180.0$ (C), $155.3(\mathrm{C}), 135.9(\mathrm{C}), 130.7(\mathrm{CH}), 128.8(\mathrm{CH}), 128.8(\mathrm{CH}), 128.6(\mathrm{CH}), 128.3(\mathrm{CH}), 125.6(\mathrm{CH})$, $125.6(\mathrm{CH}), 125.4(\mathrm{C}), 119.7(\mathrm{CH}), 117.7(\mathrm{CH}), 114.8(\mathrm{C}), 91.6(\mathrm{C}), 80.6(\mathrm{CH}), 22.9\left(\mathrm{CH}_{3}\right), 22.4$ $\left(\mathrm{CH}_{3}\right)$; IR (neat): $3359,1725,1622,1575,1388,1081,735 \mathrm{~cm}^{-1}$. HRMS Calcd for $\mathrm{C}_{19} \mathrm{H}_{19} \mathrm{O}_{4}$ $\left(\mathrm{M}+\mathrm{H}^{+}\right): 311.1283$ Found: 311.1278 .

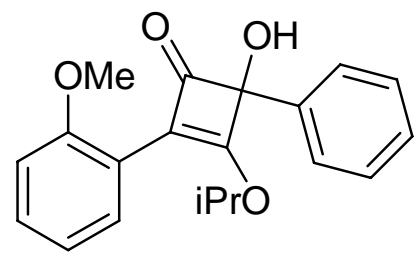

4-hydroxy-3-isopropoxy-2-(2-methoxyphenyl)-4-phenylcyclobut-2-enone (99) To a solution of cyclobutendione 96 (201 mg, $0.82 \mathrm{mmol})$ in THF (35 mL) under $\mathrm{N}_{2}$ atmosphere was added PhLi (0.78 $\mathrm{mL}, 1.17 \mathrm{mmol}, 1.5 \mathrm{M}$ in diButylether) at $-57^{\circ} \mathrm{C}$. After stirring for $5 \mathrm{~h}$, the reaction was quenched with $10 \% \mathrm{NH}_{4} \mathrm{Cl}$ in $\mathrm{H}_{2} \mathrm{O}$ and extracted with EtOAc. The combined organic portions were washed with brine, dried over $\mathrm{MgSO}_{4}$, filtered and then concentrated under reduced pressure. The residue was purified by column chromatography (hexanes:EtOAc in the order of elution, 95:5, 9:1)to afford the desired alcohol 99 (169 mg, $0.52 \mathrm{mmol}, 64 \%$ ) as a yellow oil. ${ }^{1} \mathrm{H}$ $\operatorname{NMR}(600 \mathrm{MHz})$ 6 7.61-7.59 (m, 3H), 7.37 (d, J = 7.2 Hz, 1H), 7.36 (d, J = 7.8 Hz, 1H), 7.31-7.26 $(\mathrm{m}, 2 \mathrm{H}), 6.93(\mathrm{dt}, J=7.8$ and $0.9 \mathrm{~Hz}, 1 \mathrm{H}), 6.90(\mathrm{~d}, J=8.4 \mathrm{~Hz}, 1 \mathrm{H}), 4.80($ sept $, J=6.0 \mathrm{~Hz}, 1 \mathrm{H}), 4.73$ (br s, 1H), $3.85(\mathrm{~s}, 3 \mathrm{H}), 1.37(\mathrm{~d}, J=6.0 \mathrm{~Hz}, 3 \mathrm{H}), 1.07(\mathrm{~d}, J=6.0 \mathrm{~Hz}, 3 \mathrm{H}) ;{ }^{13} \mathrm{C} \mathrm{NMR}(150 \mathrm{MHz}) \delta$ $188.0(\mathrm{C}), 179.7(\mathrm{C}), 156.9(\mathrm{C}), 137.2(\mathrm{C}), 129.8(\mathrm{CH}), 129.6(\mathrm{CH}), 128.5(\mathrm{CH}), 128.4(\mathrm{CH}), 127.9$ (CH), $125.7(\mathrm{CH}), 123.4(\mathrm{C}), 120.5(\mathrm{CH}), 117.8(\mathrm{C}), 111.2(\mathrm{CH}), 92.9(\mathrm{C}), 78.4(\mathrm{CH}), 55.5\left(\mathrm{CH}_{3}\right)$, 
$22.7\left(\mathrm{CH}_{3}\right), 22.3\left(\mathrm{CH}_{3}\right)$; IR (neat) 3308, 2981, 1742, 1616, 1488, 1082, $694 \mathrm{~cm}^{-1}$. HRMS Calcd for $\mathrm{C}_{20} \mathrm{H}_{21} \mathrm{O}_{4}\left(\mathrm{M}+\mathrm{H}^{+}\right): 325.1440$ Found: 325.1434 .<smiles>COc1ccccc1C1=C(OC(C)C)C(=O)c2ccccc2C1=O</smiles>

2-isopropoxy-3-(2-methoxyphenyl)naphthalene-1,4-dione (100) Starting alcohol 99 (78 mg, $0.24 \mathrm{mmol}$ ) dissolved in xylenes $(5 \mathrm{~mL})$ was placed in a pressure tube and then the reaction vessel was submerged in a $150{ }^{\circ} \mathrm{C}$ oil bath. The mixture was stirred for $24 \mathrm{~h}$ then the solvent was removed under reduced pressure. The resulting mixture was purified by column chromatography (hexanes:EtOAc, 9:1) to afford the naphthoquinone 100 (60 mg, $0.19 \mathrm{mmol}$, 78\%). ${ }^{1} \mathrm{H}$ NMR $(600 \mathrm{MHz}) \delta 8.13-8.10(\mathrm{~m}, 2 \mathrm{H}), 7.72(\mathrm{q}, J=1.8 \mathrm{~Hz}, 2 \mathrm{H}), 7.40-7.37(\mathrm{~m}, 1 \mathrm{H}), 7.17$ $(\mathrm{dd}, J=7.2$ and $1.8 \mathrm{~Hz}, 1 \mathrm{H}), 7.02(\mathrm{dt}, J=7.2$ and $0.9 \mathrm{~Hz}, 1 \mathrm{H}), 6.97(\mathrm{~d}, J=8.4 \mathrm{~Hz}, 1 \mathrm{H}), 4.69(\mathrm{sept}, J=$ $6.0 \mathrm{~Hz}, 1 \mathrm{H}), 3.76(\mathrm{~s}, 3 \mathrm{H}), 1.18(\mathrm{~d}, J=6.0 \mathrm{~Hz}, 3 \mathrm{H}), 1.06(\mathrm{~d}, J=6.0 \mathrm{~Hz}, 3 \mathrm{H}){ }^{13} \mathrm{C} \mathrm{NMR}(150 \mathrm{mHz}) \delta$ $184.1(\mathrm{C}), 182.4(\mathrm{C}), 157.1(\mathrm{C}), 156.6(\mathrm{C}), 133.8(\mathrm{CH}), 133.1(\mathrm{CH}), 132.6(\mathrm{C}), 132.3(\mathrm{C}), 131.6(\mathrm{C})$, $131.1(\mathrm{CH}), 130.0(\mathrm{CH}), 126.5(\mathrm{CH}), 126.2(\mathrm{CH}), 121.1(\mathrm{C}), 120.3(\mathrm{CH}), 110.9(\mathrm{CH}), 76.3(\mathrm{CH}), 55.6$ $\left(\mathrm{CH}_{3}\right), 22.8\left(\mathrm{CH}_{3}\right), 22.5\left(\mathrm{CH}_{3}\right)$; IR (neat) 2932, 1667, 1594, 1491, 1245, $998 \mathrm{~cm}^{-1}$; HRMS Calcd for $\mathrm{C} 2 \mathrm{OH} 1904\left(\mathrm{M}+\mathrm{H}^{+}\right): 323.1278$. Found 323.1278.<smiles>CC(C)Oc1c(-c2ccccc2Br)c(=O)c1=O</smiles>

3-(2-bromophenyl)-4-isopropoxycyclobut-3-ene-1,2-dione (104) At $0{ }^{\circ} \mathrm{C}$, TFAA (0.6 mL, 4.33 $\mathrm{mmoL})$ was added to a solution of $49(1.25 \mathrm{~g}, 3.52 \mathrm{mmol})$, and pyridine $(0.35 \mathrm{~mL}, 4.33 \mathrm{mmol})$ in 
ether ( $53 \mathrm{~mL}$ ). After stirring for $1 \mathrm{~h}$, the mixture was quenched with $\mathrm{H}_{2} \mathrm{O}$ and extracted with EtOAc. The combined organic portions were dried over $\mathrm{MgSO}_{4}$, filtered and solvents were removed under reduced pressure. The residue was purified by column chromatography (hexanes:EtOAc in the order of elution, 9:1, 85:15)to afford $104(1.04 \mathrm{~g}, 3.54 \mathrm{mmol}, 99 \%)$ as a yellow oil. ${ }^{1} \mathrm{H}$ NMR $(600 \mathrm{MHz}) \delta 7.70(\mathrm{dd}, J=7.8$ and $1.2 \mathrm{~Hz}, 1 \mathrm{H}), 7.66(\mathrm{dd}, J=7.8$ and $1.8 \mathrm{~Hz}, 1 \mathrm{H})$, $7.43(\mathrm{dt}, J=7.2$ and $1.2 \mathrm{~Hz}, 1 \mathrm{H}), 7.33(\mathrm{dt}, J=7.8$ and $1.8 \mathrm{~Hz}, 1 \mathrm{H}), 5.64(\mathrm{sept}, J=6.0 \mathrm{~Hz}, 1 \mathrm{H}), 1.56$ $(\mathrm{d}, J=6.0 \mathrm{~Hz}, 6 \mathrm{H}){ }^{13} \mathrm{C}$ NMR (150 MHz) 194.6 (C), 194.0 (C), 191.4 (C), 176.0 (C), 134.0 (CH), 132.6 (CH), $130.0(\mathrm{CH}), 129.2(\mathrm{C}), 127.6(\mathrm{CH}), 122.0(\mathrm{C}), 80.6(\mathrm{CH}), 23.1\left(\mathrm{CH}_{3}\right), 23.1\left(\mathrm{CH}_{3}\right) . \mathrm{IR}$ (neat): 2986, 1784, 1756, 1599, 1578, $1388 \mathrm{~cm}^{-1}$. HRMS Calcd for $\mathrm{C}_{13} \mathrm{H}_{12} \mathrm{BrO}_{3}\left(\mathrm{M}+\mathrm{H}^{+}\right): 294.9964$ Found: 294.9965.

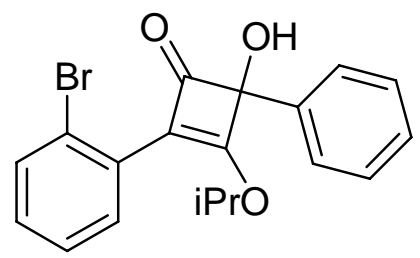

\section{2-(2-bromophenyl)-4-hydroxy-3-isopropoxy-4-phenylcyclobut-2-enone (105) At -65 ${ }^{\circ} \mathrm{C} \mathrm{PhMgCl}$}

(0.6 mL, $0.96 \mathrm{mmol}, 1.6 \mathrm{M}$ in THF) was added to a solution of cyclobutendione 104 (270 mg, $0.92 \mathrm{mmol})$ in THF $(20 \mathrm{~mL})$ under $\mathrm{N}_{2}$ atmosphere. After stirring overnight, the reaction was warmed to $-45^{\circ} \mathrm{C}$ and was stirred for an additional $2 \mathrm{~h}$. The reaction was quenched with $10 \%$ $\mathrm{NH}_{4} \mathrm{Cl}$ and extracted with EtOAc. The combined organic portions were washed with brine and dried over $\mathrm{MgSO}_{4}$, then filtered and solvents were removed under reduced pressure. The residue was purified by column chromatography (hexanes:EtOAc in the order of elution, 8:2, 7:3) to afford the alcohol $105(280 \mathrm{mg}, 0.75 \mathrm{mmol}, 82 \%) .{ }^{1} \mathrm{H}$ NMR $(270 \mathrm{MHz}) \delta 7.69-7.60(\mathrm{~m}$, 3H), 7.50-7.16 (m, 6H), $4.81(\mathrm{sept}, J=6.2 \mathrm{~Hz}, 1 \mathrm{H}), 4.42(\mathrm{br} \mathrm{s}, 1 \mathrm{H}), 1.38(\mathrm{~d}, J=6.2 \mathrm{~Hz}, 3 \mathrm{H}), 1.11$ 
(d, $J=6.2 \mathrm{~Hz}, 3 \mathrm{H}$ ); IR (neat) $3353,2982,1755,1654,1319 \mathrm{~cm}^{-1}$; HRMS Calcd for $\mathrm{C}_{19} \mathrm{H}_{18} \mathrm{BrO}_{3}$ $\left(\mathrm{M}+\mathrm{H}^{+}\right): 373.0434$ Found: 373.0435<smiles>CC(C)OC1=C(c2ccccc2Br)C(=O)c2ccccc2C1=O</smiles>

2-(2-bromophenyl)-3-isopropoxynaphthalene-1,4-dione (106) Starting alcohol 105 (200 mg, $0.54 \mathrm{mmol}$ ) dissolved in toluene $(10 \mathrm{~mL})$ was placed in a pressure tube, then the reaction vessel was sealed then submerged in a $125^{\circ} \mathrm{C}$ oil bath. The mixture was stirred for $30 \mathrm{~min}$ then the solvent was removed under reduced pressure. The residue was purified by column chromatography (hexanes:EtOAc, 7:3) to afford 106 (194 mg, $0.52 \mathrm{mmol}, 98 \%$ ) as a yelloworange solid. ${ }^{1} \mathrm{H}$ NMR $(600 \mathrm{MHz}) \delta 8.11(\mathrm{~d}, J=8.4 \mathrm{~Hz}, 2 \mathrm{H}), 7.75-7.70(\mathrm{~m}, 2 \mathrm{H}), 7.65(\mathrm{~d}, J=7.8 \mathrm{~Hz}$, $1 \mathrm{H}), 7.38(\mathrm{t}, J=7.2 \mathrm{~Hz}, 1 \mathrm{H}), 7.27-7.23(\mathrm{~m}, 2 \mathrm{H}), 4.90(\operatorname{sept}, J=6.0 \mathrm{~Hz}, 1 \mathrm{H}), 1.20(\mathrm{~d}, J=6.0 \mathrm{~Hz}, 3 \mathrm{H})$, $1.12(\mathrm{~d}, J=6.0 \mathrm{~Hz}, 3 \mathrm{H}) ;{ }^{13} \mathrm{C}$ NMR $(150 \mathrm{MHz}) \delta 183.3(\mathrm{C}), 182.1(\mathrm{C}), 156.4(\mathrm{C}), 134.0(\mathrm{CH}), 133.7$ (C), $133.3(\mathrm{C}), 133.3(\mathrm{CH}), 132.1(\mathrm{CH}), 131.8(\mathrm{C}), 131.4(\mathrm{C}), 131.4(\mathrm{CH}), 129.7(\mathrm{CH}), 126.8(\mathrm{CH})$, $126.5(\mathrm{CH}), 126.2(\mathrm{CH}), 123.7(\mathrm{C}), 76.8(\mathrm{CH}), 22.9\left(\mathrm{CH}_{3}\right), 22.8\left(\mathrm{CH}_{3}\right)$. IR (neat) 2980, 1670, 1595, 1330, 1201, 997, 721; HRMS Calcd for $\mathrm{C}_{19} \mathrm{H}_{16} \mathrm{BrO}_{3}\left(\mathrm{M}+\mathrm{H}^{+}\right)$: 371.0277 Found: 371.0277 .<smiles>NC1=C(c2ccccc2Br)C(=O)c2ccccc2C1=O</smiles> 
2-amino-3-(2-bromophenyl)naphthalene-1,4-dione (109) To a round bottom flask containing naphthoquinone 106 (194 mg, $0.52 \mathrm{mmol}$ ) was added 30\% $\mathrm{NH}_{4} \mathrm{OH}(30 \mathrm{~mL}$ ) followed by $\mathrm{MeOH}$ $(8 \mathrm{~mL})$. The mixture was stirred for 3 days and was quenched with $10 \% \mathrm{NH}_{4} \mathrm{Cl}$ and extracted with EtOAc. The combined organic portions were washed with brine, dried over $\mathrm{MgSO}_{4}$, filtered and then solvents were removed under reduced pressure. The residue was purified by column chromatography (hexanes:EtOAc in the order of elution, 8:2, 7:3) to afford the amine 109 (104 $\mathrm{mg}, 0.32 \mathrm{mmol}, 62 \%)$ as a red-orange solid. ${ }^{1} \mathrm{H} \mathrm{NMR}(600 \mathrm{MHz}) \delta 8.16(\mathrm{dd}, J=7.8$ and $1.2 \mathrm{~Hz}$, 1H), $8.12(\mathrm{dd}, J=7.8$ and $1.2 \mathrm{~Hz}, 1 \mathrm{H}), 7.75(\mathrm{dt}, J=7.8$ and $1.2 \mathrm{~Hz}, 1 \mathrm{H}), 7.73(\mathrm{dd}, J=8.4$ and 1.2 $\mathrm{Hz}, 1 \mathrm{H}), 7.67(\mathrm{dt}, J=7.8$ and $1.2 \mathrm{~Hz}, 1 \mathrm{H}), 7.43(\mathrm{dt}, J=7.8$ and $1.2 \mathrm{~Hz}, 1 \mathrm{H}), 7.30-7.27(\mathrm{~m}, 2 \mathrm{H}), 5.03$ (br s, 2H); ${ }^{13} \mathrm{C}$ NMR (150 MHz) $\delta 181.5(+), 180.9(+), 145.1(+), 134.8,(-), 133.6(+), 133.4(-)$, $133.2(+), 132.3(-), 132.0(-), 130.5(+), 130.1(-), 128.0(-), 126.7(-), 126.0(-), 124.7(+), 116.9$ (+); IR (neat) 3476, 3337, 1683, 1605, 1567, 1351, $757 \mathrm{~cm}^{-1}$; HRMS Calcd for $\mathrm{C}_{16} \mathrm{H}_{11} \mathrm{BrNO}_{3}$ $\left(\mathrm{M}+\mathrm{H}^{+}\right): 327.9968$ Found: 327.9968.

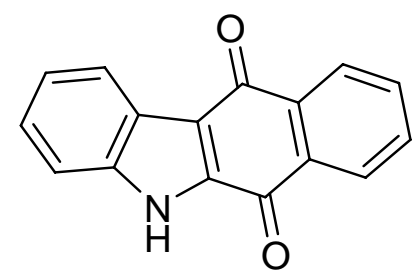

5H-benzo[b]carbazole-6,11-dione (110) To a pressure tube was added 109 (150 mg, 0.46 $\mathrm{mmoL}$ ), Cul (14 mg, $0.074 \mathrm{mmol}), \mathrm{K}_{2} \mathrm{CO}_{3}(130 \mathrm{mg}, 0.94 \mathrm{mmol})$, and pipecolinic acid (12 mg, $0.093 \mathrm{mmol})$ in DMF $(1 \mathrm{~mL})$. The reaction vessel was sealed then submerged in a $100{ }^{\circ} \mathrm{C}$ oil bath. After stirring for $12 \mathrm{~h}$, the mixture was diluted with EtOAc and filtered through celite. The solvents were removed under reduced pressure and the residue was purified by column chromatography (hexanes:EtOAc, 8:2) to afford 110 (65 mg, $0.27 \mathrm{mmol}, 59 \%)$ as an orange 
solid. ${ }^{1} \mathrm{H}$ NMR in DMSO $(600 \mathrm{MHz}) \delta 8.17(\mathrm{~d}, J=7.8 \mathrm{~Hz}, 1 \mathrm{H}), 8.07(\mathrm{~d}, J=7.8 \mathrm{~Hz}, 1 \mathrm{H}), 8.05(\mathrm{~d}, J=$ $7.8 \mathrm{~Hz}, 1 \mathrm{H}), 7.81(\mathrm{t}, J=7.2 \mathrm{~Hz}, 1 \mathrm{H}), 7.76(\mathrm{t}, J=7.8 \mathrm{~Hz}, 1 \mathrm{H}), 7.57,(\mathrm{~d}, J=7.8 \mathrm{~Hz}, 1 \mathrm{H}), 7.39$ (dt, $J=$ 7.2 and $1.2 \mathrm{~Hz}, 1 \mathrm{H}), 7.31(\mathrm{t}, J=7.8 \mathrm{~Hz}, 1 \mathrm{H}) ;{ }^{13} \mathrm{C}$ NMR $(67.5 \mathrm{MHz}) \delta 180.3(+), 177.5(+), 138.2(+)$, $137.1(+), 134.2(-), 134.0(+), 133.1(-), 132.6(+), 126.9(-), 126.0(-), 125.9(-), 124.0(-), 122.3(-$ ), $117.4(+), 113.8$ (-); IR (neat) 3261, 1645, 1520, 1397, 1212, $753 \mathrm{~cm}^{-1}$, HRMS cald for $\mathrm{C}_{16} \mathrm{H}_{10} \mathrm{NO}_{2}\left(\mathrm{M}+\mathrm{H}^{+}\right): 248.0706$ Found:248.0706.

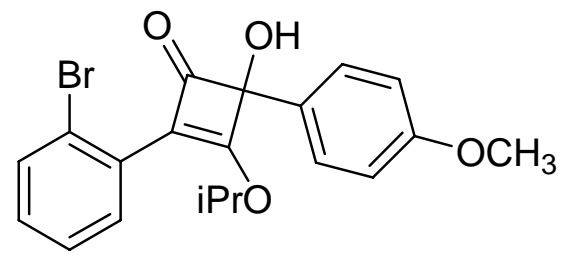

2-(2-bromophenyl)-4-hydroxy-3-isopropoxy-4-(4-methoxyphenyl)cyclobut-2-enone (111) At $75^{\circ} \mathrm{C}$ 4-anisylmagnesium bromide (1.6 mL, $0.80 \mathrm{mmol}, 5 \mathrm{M}$ in THF ) was added to 104 (215 mg, $0.73 \mathrm{mmol}$ ) dissolved in THF (18 mL). After stirring for $48 \mathrm{~h}$, the reaction was quenched with $10 \% \mathrm{NH}_{4} \mathrm{Cl}$ in $\mathrm{H}_{2} \mathrm{O}$ and extracted with EtOAc. The combined organic portions were washed with brine, dried over $\mathrm{MgSO}_{4}$, filtered and then the solvents were removed under reduced pressure. The residue was purified by column chromatography (hexanes:EtOAc in the order of elution, 95:5, 9:1, 85:15, 8:2) to afford 111 (179 mg, $0.44 \mathrm{mmol}, 61 \%)$ as a colorless oil: ${ }^{1} \mathrm{H}$ NMR (270 $\mathrm{mHz}$ ) 7.63-7.55 (m, 2H), $7.47(\mathrm{dd}, J=7.4$ and $1.2 \mathrm{~Hz}, 1 \mathrm{H}), 7.32(\mathrm{dt}, J=7.4$ and $1.2 \mathrm{~Hz}, 1 \mathrm{H}), 7.20$ (dt, $J=7.9$ and $1.7 \mathrm{~Hz}, 1 \mathrm{H}), 6.96-6.93(\mathrm{~m}, 2 \mathrm{H}), 4.80(\mathrm{sept}, J=6.2 \mathrm{~Hz}, 1 \mathrm{H}), 3.83(\mathrm{~s}, 3 \mathrm{H}), 1.39(\mathrm{~d}, J=$ 6.2, 3H), $1.14(\mathrm{~d}, J=6.2 \mathrm{~Hz}, 3 \mathrm{H}) ;{ }^{13} \mathrm{C}$ NMR (67.5 MHz) $188.2(+), 180.9(+), 159.5(+), 132.9(-)$, $131.0(-), 129.8(+), 129.5(-), 128.6(+), 127.1(-), 125.3(+), 122.4(+), 114.0(-), 92.6(+), 79.2(-)$, $55.2(-), 22.7(-), 22.4(-)$. 
<smiles>COc1ccc2c(c1)C(=O)C(c1ccccc1Br)=C(OC(C)C)C2=O</smiles>

\section{3-(2-bromophenyl)-2-isopropoxy-6-methoxynaphthalene-1,4-dione (112)}

Hydroxycyclobutenone 111 (44 mg, $0.11 \mathrm{mmol}$ ) dissolved in xylenes $(5 \mathrm{~mL}$ ) was placed in a pressure tube and then the reaction vessel was sealed then submerged in a $136{ }^{\circ} \mathrm{C}$ oil bath. After stirring for $3 \mathrm{~h}$, the solvent was removed under reduced pressure. The residue was purified by column chromatography (hexanes :EtOAc, 9:1) to afford the naphthoquinone 112 (43 mg, $0.11 \mathrm{mmol}, 100 \%)$ as an orange oil: ${ }^{1} \mathrm{H}$ NMR $(600 \mathrm{mHz}) \delta 8.07(\mathrm{~d}, J=9.0 \mathrm{~Hz}, 1 \mathrm{H}), 7.66(\mathrm{dd}, J=8.4$ and $1.2 \mathrm{~Hz}, 1 \mathrm{H}), 7.57(\mathrm{~d}, J=2.4 \mathrm{~Hz}), 7.38(\mathrm{dt}, J=7.2$ and $1.2 \mathrm{~Hz}, 1 \mathrm{H}), 7.26(\mathrm{dt}, \mathrm{J}=7.8$ and $1.8 \mathrm{~Hz}$, 1H), $7.22(\mathrm{dd}, J=7.2$ and $1.2 \mathrm{~Hz}, 1 \mathrm{H}), 7.20(\mathrm{dd}, \mathrm{J}=9.0$ and $1.8 \mathrm{~Hz}, 1 \mathrm{H}), 4.92($ sept, $J=6.0 \mathrm{~Hz}, 1 \mathrm{H}$ ), $3.95(\mathrm{~s}, 3 \mathrm{H}), 1.20(\mathrm{~d}, J=6.0 \mathrm{~Hz}, 3 \mathrm{H}), 1.11(\mathrm{~d}, J=6.2 \mathrm{~Hz}, 3 \mathrm{H}), 13 \mathrm{C}$ NMR $(150 \mathrm{MHz}) \delta 183.5(\mathrm{C})$, $181.2(\mathrm{C}), 164.5(\mathrm{C}), 156.9$ (C), 134.2 (C), 133.6 (C), $133.4(\mathrm{C}), 132.4(\mathrm{CH}), 131.5(\mathrm{CH}), 129.7(\mathrm{CH})$, $128.9(\mathrm{CH}), 126.9(\mathrm{CH}), 125.1(\mathrm{C}), 123.9(\mathrm{C}), 120.0(\mathrm{CH}), 110.0(\mathrm{CH}), 76.9(\mathrm{CH}), 56.0(\mathrm{CH}), 23.0$ $\left(\mathrm{CH}_{3}\right), 23.0\left(\mathrm{CH}_{3}\right), \mathrm{IR}$ (neat) 2930, 1667, 1594, 1318, 1239, 1006, $751 \mathrm{~cm}^{-1}$, HRMS Calcd for $\mathrm{C}_{20} \mathrm{H}_{18} \mathrm{BrO}_{4}\left(\mathrm{M}+\mathrm{H}^{+}\right): 401.0383$, Found:401.0385.<smiles>COc1ccc2c(c1)C(=O)C(c1ccccc1Br)=C(N)C2=O</smiles>

2-amino-3-(2-bromophenyl)-6-methoxynaphthalene-1,4-dione (113) To a round bottom flask containing isopropyl naphthoquinone $112(1.10 \mathrm{~g}, 2.75 \mathrm{mmol})$, was added $30 \% \mathrm{NH}_{4} \mathrm{OH}(30 \mathrm{~mL})$ 
followed by $\mathrm{MeOH}(30 \mathrm{~mL})$. The mixture was stirred for 2 days and was quenched with $10 \%$ $\mathrm{NH}_{4} \mathrm{Cl}$ and extracted with EtOAc. The combined organic portions were washed with brine then dried over $\mathrm{MgSO}_{4}$, filtered and the solvents were removed under reduced pressure. The compound was purified by column chromatography (Hexanes:EtOAc in the order of elution, $85: 15,8 ; 2)$ to afford the amine 113 (575 mg, $1.6 \mathrm{mmol}, 58 \%) .{ }^{1} \mathrm{H}$ NMR $(600 \mathrm{MHz}) \delta 8.06(\mathrm{~d}, J=$ 8.4, $1 \mathrm{H}), 7.72(\mathrm{dd}, J=8.4$ and $1.2,1 \mathrm{H}), 7.62(\mathrm{~d}, J=3.0,1 \mathrm{H}), 7.42(\mathrm{dt}, J=7.8$ and $1.2,1 \mathrm{H}), 7.29$ $7.26(\mathrm{~m}, 2 \mathrm{H}), 7.11(\mathrm{dd}, J=8.4$ and 3.0, $1 \mathrm{H}), 3.95(\mathrm{~s}, 3 \mathrm{H}){ }^{13} \mathrm{C} N M R(150 \mathrm{MHz}) \delta 180.6(\mathrm{C}), 180.2$ (C), $165.1(\mathrm{C}), 145.5(\mathrm{C}), 135.8(\mathrm{C}), 133.8(\mathrm{C}), 133.3(\mathrm{CH}), 132.0(\mathrm{CH}), 130.0(\mathrm{CH}), 128.8(\mathrm{CH})$, $128.0(\mathrm{CH}), 124.8(\mathrm{C}), 123.9(\mathrm{C}), 118.7(\mathrm{CH}), 116.4(\mathrm{C}), 110.5(\mathrm{CH}), 55.9\left(\mathrm{CH}_{3}\right) ; \quad I R$ (neat) 3315, $1675,1556,1340,1262,750 \mathrm{~cm}^{-1}$; HRMS Calcd for $\mathrm{C}_{17} \mathrm{H}_{13} \mathrm{BrNO}_{3}\left(\mathrm{M}+\mathrm{H}^{+}\right): 358.0078$ Found: 358.0073 .

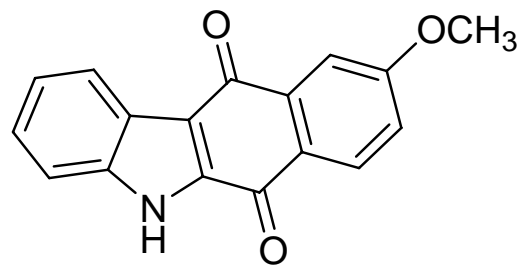

9-methoxy-5H-benzo[b]carbazole-6,11-dione (114) 113 (49 mg, .14 mmol), Cul (2.7 mg, .014 mmol), pipecolinic acid (3.6 mg, $0.028 \mathrm{mmol})$, and $\mathrm{K}_{2} \mathrm{CO}_{3}(39 \mathrm{mg}, 0.282 \mathrm{mmol})$ in $\mathrm{DMF}(0.2 \mathrm{~mL})$ were added to a pressure tube then the reaction vessel was sealed then submerged in a $110{ }^{\circ} \mathrm{C}$ oil bath. After stirring for $24 \mathrm{~h}$, the mixture filtered with through celite, washing with EtOAc The solvent was the removed under reduced pressure and the residue was purified by column chromatography (hexanes:EtOAc, 8:2) to afford the desired carbazolequinone 114 (22 mg, 0.08 mmol, 58\%). ${ }^{1} \mathrm{H}$ NMR (600 MHz, DMSO) $\delta 13.01(\mathrm{br} \mathrm{s}, 1 \mathrm{H}), 8.18(\mathrm{~d}, J=8.4 \mathrm{~Hz}, 1 \mathrm{H}), 8.04(\mathrm{~d}, J=$ $9.0 \mathrm{~Hz}, 1 \mathrm{H}), 7.58(\mathrm{~d}, J=8.4 \mathrm{~Hz}, 1 \mathrm{H}), 7.54(\mathrm{~d}, J=3.0 \mathrm{~Hz}, 1 \mathrm{H}), 7.43(\mathrm{dt}, J=8.4$ and $1.2 \mathrm{~Hz}, 1 \mathrm{H}), 7.36$ 
(dt, $J=7.8$ and $0.6 \mathrm{~Hz}, 1 \mathrm{H}), 7.29(\mathrm{dd}, J=8.4$ and $3.0,1 \mathrm{H}), 3.95(\mathrm{~s}, 3 \mathrm{H}){ }^{13} \mathrm{C} \mathrm{NMR}(150 \mathrm{MHz}$, DMSO) $\delta 180.6,177.4,164.7,138.7,138.3,137.2,129.4,127.4,126.5,124.7,124.6,122.9$, 118.7, 117.9, 114.5, 111.8, 56.6; IR (neat): 3217, 2922, 1656, 1585, 1394, 1257, 1017, $756 \mathrm{~cm}^{-1}$, HRMS Calcd for $\mathrm{C}_{17} \mathrm{H}_{12} \mathrm{NO}_{3}\left(\mathrm{M}+\mathrm{H}^{+}\right): 278.0812$ Found: 278.0812

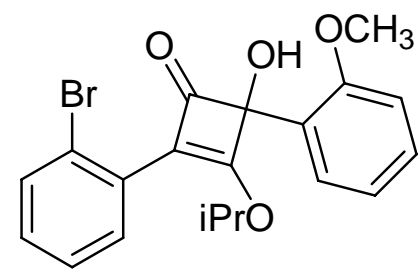

2-(2-bromophenyl)-4-hydroxy-3-isopropoxy-4-(2-methoxyphenyl)cyclobut-2-enone (115) At $78{ }^{\circ} \mathrm{C}$. 2-anisylmagnesium bromide (1.6 mL, $1.12 \mathrm{mmol}, 0.7 \mathrm{M}$ in THF) was added to 104 (301 $\mathrm{mg}, 1.02 \mathrm{mmol}$ ) dissolved in THF ( $35 \mathrm{~mL})$ under $\mathrm{N}_{2}$ atmosphere. After stirring for $1 \mathrm{~h}$, the reaction was quenched with $10 \% \mathrm{NH}_{4} \mathrm{Cl}$ in $\mathrm{H}_{2} \mathrm{O}$ and extracted with EtOAc. The combined organic portions were washed with brine, dried over $\mathrm{MgSO}_{4}$, filtered and then the solvents were removed under reduced pressure. The residue was purified by column chromatography (hexanes:EtOAc in the order of elution, 9:1, 85:15) to afford the alcohol 115 (397 mg, 0.98 mmol, 97\%) as a colorless oil: ${ }^{1} \mathrm{H}$ NMR $(600 \mathrm{MHz}) \delta 7.56(\mathrm{dd}, J=8.4$ and $0.9 \mathrm{~Hz}, 1 \mathrm{H}) ; 7.53(\mathrm{dd}, J=$ 7.8 and $1.2 \mathrm{~Hz}, 1 \mathrm{H}), 7.47(\mathrm{dd}, J=7.8$ and $1.8 \mathrm{~Hz}, 1 \mathrm{H}), 7.3-7.26(\mathrm{~m}, 2 \mathrm{H}) 7.14(\mathrm{dt}, J=7.8$ and 1.8 $\mathrm{Hz}, 1 \mathrm{H}), 6.99(\mathrm{dt}, J=7.8$ and $0.9 \mathrm{~Hz}, 1 \mathrm{H}), 6.94(\mathrm{~d}, J=7.8,1 \mathrm{H}), 5.44(\mathrm{~s}, 1 \mathrm{H}), 4.83(\mathrm{sept}, J=6.0 \mathrm{~Hz}$, $1 \mathrm{H}), 3.86(\mathrm{~s}, 3 \mathrm{H}), 1.38(\mathrm{~d}, J=6.0 \mathrm{~Hz}, 3 \mathrm{H}), 1.22(\mathrm{~d}, J=6.0 \mathrm{~Hz}, 3 \mathrm{H}){ }^{13} \mathrm{C} \mathrm{NMR}(150 \mathrm{MHz}) 180.9$ (C), $179.2(\mathrm{C}), 157.1(\mathrm{C}), 132.7(\mathrm{CH}), 130.7(\mathrm{CH}), 129.7(\mathrm{CH}), 129.6(\mathrm{CH}), 129.5(\mathrm{C}), 127.6(\mathrm{CH}), 126.9$ (CH), $124.5(\mathrm{C}), 124.3(\mathrm{C}), 122.3(\mathrm{C}), 121.1(\mathrm{CH}), 111.7(\mathrm{CH}), 93.168(\mathrm{C}), 78.6(\mathrm{CH}), 55.9\left(\mathrm{CH}_{3}\right)$, $22.4\left(\mathrm{CH}_{3}\right), 22.0\left(\mathrm{CH}_{3}\right) ; \delta$ IR (neat) 3339, 2982, 1743, 1615, 1578, 1384, $1058 \mathrm{~cm}^{-1}$. 
<smiles>COc1cccc2c1C(=O)C(OC(C)C)=C(c1ccccc1Br)C2=O</smiles>

2-(2-bromophenyl)-3-isopropoxy-5-methoxynaphthalene-1,4-dione (116) The arylalcohol 115 (390 mg, $0.97 \mathrm{mmol}$ ) was dissolved in xylenes $(10 \mathrm{~mL})$ and transferred to a pressure tube. Then the reaction vessel was sealed then submerged in a $150{ }^{\circ} \mathrm{C}$ oil bath. After stirring for $5 \mathrm{~h}$, the solvent was removed under reduced pressure. The residue was purified by column chromatography (hexanes:EtOAc, 9:1) to afford 116 (245 mg, $0.61 \mathrm{mmol}, 63 \%$ ) as an orange oil: ${ }^{1} \mathrm{H}$ NMR $(600 \mathrm{MHz}) \delta 7.77(\mathrm{dd}, 7.8$ and $0.9 \mathrm{~Hz}, 1 \mathrm{H}), 7.61(\mathrm{~d}, J=8.4 \mathrm{~Hz}, 1 \mathrm{H}), 7.64(\mathrm{dt}, J=8.4$ and $0.9 \mathrm{~Hz}, 1 \mathrm{H}), 7.36(\mathrm{dt}, J=7.2$ and $1.2 \mathrm{~Hz}, 1 \mathrm{H}), 7.29-7.22(\mathrm{~m}, 3 \mathrm{H}), 4.88($ sept $, J=6.0 \mathrm{~Hz}, 1 \mathrm{H}), 4.01$ (s, 3H), $1.21(\mathrm{~d}, J=6.0 \mathrm{~Hz}, 3 \mathrm{H}), 1.11(\mathrm{~d}, J=6.0 \mathrm{~Hz}, 3 \mathrm{H}) ;{ }^{13} \mathrm{C} \mathrm{NMR}(150 \mathrm{MHz}) \delta 183.3(\mathrm{C}), 180.7$ (C), 159.5 (C), 157.5 (C), $135.1(\mathrm{CH}), 134.2(\mathrm{C}), 133.2(\mathrm{C}), 132.2(\mathrm{CH}), 131.6(\mathrm{C}), 131.4(\mathrm{CH}), 129.5$ $(\mathrm{CH}), 126.8(\mathrm{CH}), 123.7(\mathrm{C}), 119.4(\mathrm{C}), 119.1(\mathrm{CH}), 117.2(\mathrm{CH}), 76.7(\mathrm{CH}), 56.4\left(\mathrm{CH}_{3}\right), 22.9\left(\mathrm{CH}_{3}\right)$, $22.8\left(\mathrm{CH}_{3}\right)$; IR (neat) 2979, 1665, 1583, 1282, 1187, $999 \mathrm{~cm}^{-1}$; HRMS Calcd for $\mathrm{C}_{20} \mathrm{H}_{18} \mathrm{BrNO}_{4}$ $\left(\mathrm{M}+\mathrm{H}^{+}\right): 401.0383$ Found: 401.0388.<smiles>COc1cccc2c1C(=O)C(N)=C(c1ccccc1Br)C2=O</smiles>

3-amino-2-(2-bromophenyl)-5-methoxynaphthalene-1,4-dione (117) To a round bottom flask containing 116 (123 mg, $0.31 \mathrm{mmol}$ ) was added 30\% $\mathrm{NH}_{4} \mathrm{OH}(20 \mathrm{~mL})$ followed by $\mathrm{MeOH}(2 \mathrm{~mL})$. 
The mixture was stirred for 3 days and was quenched with $10 \% \mathrm{NH}_{4} \mathrm{Cl}$ and extracted with EtOAc. The combined organic portions were washed with brine, dried over $\mathrm{MgSO}_{4}$, filtered and then solvents were removed under reduced pressure. The residue was purified by column chromatography (hexanes:EtOAc in the order of elution, 9:1, 85;15) to afford the amine 117 (52 $\mathrm{mg}, 0.15 \mathrm{mmol}, 48 \%)$ as a red-orange solid. ${ }^{1} \mathrm{H} \mathrm{NMR}(600 \mathrm{MHz}) \delta 7.84(\mathrm{dd}, J=7.8$ and $1.2 \mathrm{~Hz}$, 1H), $7.71(\mathrm{dd}, J=7.8$ and $1.2 \mathrm{~Hz}, 1 \mathrm{H}) 7.69(\mathrm{dd}, J=7.8$ and $0.6,1 \mathrm{H}), 7.42(\mathrm{dt}, J=$ and $1.2 \mathrm{~Hz}, 1 \mathrm{H})$, 7.29-7.26 (m, 2H) $7.23(\mathrm{dd}, J=8.4$ and $1.2 \mathrm{~Hz}, 1 \mathrm{H}) 4.04(\mathrm{~s}, 3 \mathrm{H}) ;{ }^{13} \mathrm{C} \mathrm{NMR}(150 \mathrm{MHz}) \delta 180.4(\mathrm{C})$, $179.8(\mathrm{C}), 160.0(\mathrm{C}), 146.1(\mathrm{C}), 136.0(\mathrm{CH}), 135.6(\mathrm{C}), 133.8(\mathrm{C}), 133.3(\mathrm{CH}), 132.1(\mathrm{CH}), 130.0$ (CH), $128.0(\mathrm{CH}), 124.8(\mathrm{C}), 119.6(\mathrm{CH}) 118.3(\mathrm{C}), 116.1(\mathrm{CH}), 115.3(\mathrm{C}), 56.3\left(\mathrm{CH}_{3}\right)$; IR (neat) 3447, 3340, 1610, 1574, 1471, $749 \mathrm{~cm}^{-1}$; HRMS Calcd for $\mathrm{C}_{17} \mathrm{H}_{13} \mathrm{BrNO}_{3}\left(\mathrm{M}+\mathrm{H}^{+}\right): 358.0073$ Found: 358.0073.

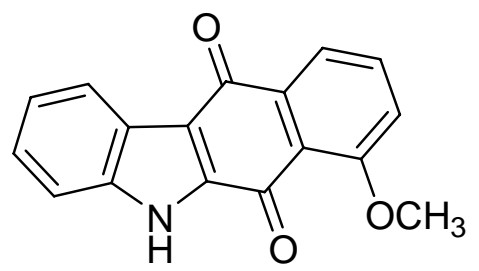

7-methoxy-5H-benzo[b]carbazole-6,11-dione (118) To a pressure tube was added 117 (15 mg, $0.042 \mathrm{mmoL}), \mathrm{Cul}(1 \mathrm{mg}, 0.0053 \mathrm{mmol}), \mathrm{K}_{2} \mathrm{CO}_{3}(12 \mathrm{mg}, 0.087 \mathrm{mmol})$, and pipecolinic acid (1 $\mathrm{mg}$, $0.0078 \mathrm{mmol})$ in DMF $(1 \mathrm{~mL})$. The reaction vessel was sealed then submerged in a $110{ }^{\circ} \mathrm{C}$ oil bath. After stirring for $12 \mathrm{~h}$, the mixture was diluted with EtOAc and filtered through celite. The solvents were removed under reduced pressure and the residue was purified by column chromatography (hexanes:EtOAc in the order of elution, 95:5, 9:1, 85:15, 8:2) to afford 118 (5 $\mathrm{mg}, 0.0 .018 \mathrm{mmol}, 43 \%)$ as an orange solid. ${ }^{1} \mathrm{H}$ NMR in DMSO (600 MHz) $\delta 12.8(\mathrm{~s}, 1 \mathrm{H}), 8.16(\mathrm{~d}$, $J=7.8 \mathrm{~Hz}, 1 \mathrm{H}), 7.79(\mathrm{t}, J=8.4 \mathrm{~Hz}, 1 \mathrm{H}), 7.78(\mathrm{dd}, J=7.8$ and $1.2 \mathrm{~Hz}, 1 \mathrm{H}), 7.59,(\mathrm{~d}, J=7.8 \mathrm{~Hz}, 1 \mathrm{H})$, 
$7.53(\mathrm{dd}, J=7.8$ and $1.2 \mathrm{~Hz}, 1 \mathrm{H}), 7.42(\mathrm{dt}, J=7.2$ and $1.2 \mathrm{~Hz}, 1 \mathrm{H}), 7.34(\mathrm{dt}, J=7.2$ and $1.2 \mathrm{~Hz}, 1 \mathrm{H})$

3.97 (s, 3H); ${ }^{13} \mathrm{C}$ NMR (150 MHz) $\delta 180.4$ (C), 177.5 (C), 160 (C), 139.4 (C), 138.4 (C), 137.2 (C),

$136.2(\mathrm{CH}), 127.1(\mathrm{CH}), 124.4(\mathrm{CH}), 124.3(\mathrm{C}), 122.9(\mathrm{CH}), 120.2(\mathrm{C}), 119.5(\mathrm{CH}), 119.2(\mathrm{CH}), 116.2$

(CH), 114.4 (CH), 57.1 (C); IR (neat) 3242, 1646, 1584, 1235, 1019, $741 \mathrm{~cm}^{-1}$, HRMS cald for

$\mathrm{C}_{17} \mathrm{H}_{12} \mathrm{NO}_{3}\left(\mathrm{M}+\mathrm{H}^{+}\right):$278.0812 Found:278.0812.

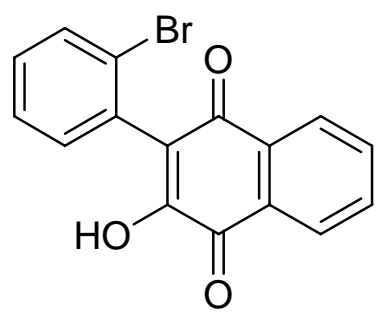

2-(2-bromophenyl)-3-hydroxynaphthalene-1,4-dione (119) To a solution of 106 (43 mg, 0.12 $\mathrm{mmol})$ in methylene chloride $(4 \mathrm{~mL})$ was added $\mathrm{BBr}_{3}(0.11 \mathrm{~mL}, 0.11 \mathrm{mmol})$. After stirring for 2 $h$, the reaction was quenched with $\mathrm{H}_{2} \mathrm{O}$, and extracted with methylene chloride. The combined organic portions were dried over $\mathrm{MgSO}_{4}$, filtered and then the solvent was removed under reduced pressure.(119) ${ }^{1} \mathrm{H}$ NMR $(600 \mathrm{MHz}) \delta 8.20(\mathrm{dd}, \mathrm{J}=7.8$ and $0.6 \mathrm{~Hz}, 1 \mathrm{H}), 8.18(\mathrm{dd}, \mathrm{J}=7.8$ and $1.2 \mathrm{~Hz}, 1 \mathrm{H}$ ), $7.83(\mathrm{dt}, \mathrm{J}=7.8$ and $1.2 \mathrm{~Hz}, 1 \mathrm{H}), 7.76(\mathrm{dt}, \mathrm{J}=7.8$ and $1.2 \mathrm{~Hz}, 1 \mathrm{H}), 7.69(\mathrm{dd}, \mathrm{J}=$ 7.8 and $1.2 \mathrm{~Hz}, 1 \mathrm{H}), 7.41(\mathrm{dt}, \mathrm{J}=7.8$ and $1.2 \mathrm{~Hz}, 1 \mathrm{H}), 7.29(\mathrm{dt}, \mathrm{J}=7.8$ and $1.8 \mathrm{~Hz}, 1 \mathrm{H}), 7.27(\mathrm{dd}, \mathrm{J}$ $=7.2$ and $1.2 \mathrm{~Hz}, 1 \mathrm{H}) ; 13 \mathrm{C} N M R \delta 182.7(\mathrm{C}), 181.6(\mathrm{C}), 152.7(\mathrm{C}), 135.4(\mathrm{CH}), 133.2(\mathrm{CH}), 132.8$ (C), $132.8(\mathrm{CH}), 131.9(\mathrm{C}), 131.5(\mathrm{CH}), 130.2(\mathrm{CH}), 129.4(\mathrm{C}), 127.3(\mathrm{CH}), 127.2(\mathrm{CH}), 126.4(\mathrm{CH})$, 123.9 (C), 122.7 (C); IR(neat) 3229, 1674, 1640, 1595, 1364, 1004, $726 \mathrm{~cm}^{-1}$; HRMS Calcd for $\mathrm{C}_{16} \mathrm{H}_{10} \mathrm{BrO}_{3}\left(\mathrm{M}+\mathrm{H}^{+}\right): 328.9808$ Found: 328.9809. 


\section{References}

1. Thompson, R. H. Naturally Occurring Quinones IV; Blackie Academic \& Professional: New York, NY, 1997.

2. Brodie, A. F. In Biochemistry of Quinones; Morton, R. A., Ed.;Academic Press: New York, NY, 1965, pp 356-399.

3. Couladouros, E. A.; Strongilos, A. T. Sci. Synthesis. 2006, 28, 217-322.

4. Dotz, K. H.; Tomuschat, P.; Chem. Soc. Review 1999, 28, 187-198.

5. Czakó, B.; Pulley, S. R. Tetrahedron Lett. 2004, 45, 5511-5514.

6. Caldwell, J. J.; Colman, R.; Kerr, W. J.; Magennis, E. J. Synlett 2001, 9, 1428-1430.

7. Kraus, G. A.; Cho, H.; Crowley, S.; Roth, B.; Sugimoto, H.; Prugh, S.; J. Org. Chem.; 1983, 48, 3439.

8. Hauser, F. M.; Rhee, R. P.; J. Org. Chem., 1978, 43, 178.

9. Couladrouros, E. A.; Strongilos, A. T.; Papageorgiou, V. P.; Plyta, Z. F. Chem.--Eur. J. 2002, 2002, 1795-1803.

10. Brisson, C.; Brassard, P.; J. Org. Chem. 1981, 46, 1810.

11. Noland, W. E.; Kedrowski, B. L.; J. Org. Chem. 1999, 64, 596.

12. Matsumoto, T.; Yamaguchi, H.; Tanabe, M.; Yasui, Y.; Suzuki, K.; Tetrahedron Lett., 2000, 41, 8393.

13. Kobayashi, K.; Yoneda, K., Uchida, M.; Matsuoka, H.; Morikawa, O.; Konishi, H., Heterocycles, 2001, 55, 2423.

14. Storck, W.; Manecke, G., Chem. Ber., 1969, 102, 3584.

15. Akai, S.; Takeda, Y.; Lio, K.; Yoshida, Y.; Kita, Y., J. Chem. Soc., Chem. Commun., 1995, 1013.

16. Tou, J. S.; Reusch, W., J. Org. Chem., 1980, 45, 5012.

17. Brisson, C.; Brassard, P.; J. Org. Chem. 1981, 46, 1810.

18. Guzikowski, A. P.; Cai, S. X.; Espitia, S. A.; Hawkinson, J. E.; Huettner, J. E.; Nogales, D. F.; Tran, M.; Woodward, R. M.; Weber, E.; Keana, J. F. W., J. Med. Chem., 1996, 39, 4643.

19. Willmore, N. D.; Hoic, D. A.; Katz, T. J.; J. Org. Chem., 1994, 59, 1889. 
20. Avalos, L. S.; Benitez, A.; Muchowski, J. M.; Romero, M.; Talamas, F. X.; Heterocycles, 1997, 45, 1795.

21. Noland, W. E.; Konkel, M. J.; Tempesta, M. S.; Cink, R. D.; Powers, D. M.; Schlemper, E. O. Barnes, C. L., J. Heterocycl. Chem., 1993, 30, 183.

22. Matsumoto, T.; Hosoya, T.; Katsuki, M.; Suzuki, K., Tetrahedron Lett., 1991, 32, 6735.

23. Li, Z.; Gao, Y.; Tang, Y.; Dai, M.; Wang, G.; Wang, Z.; Yang, Z. Org. Lett. 2008, 10, 3017-3020.

24. Giles, R.; Green, I.; Eeden, N. v. Eur. J. Org. Chem. 2004, 21, 4416-4423.

25. Moore, H. W.; Decker, O. H. W.; Chem Rev., 1986, 86, 821-830.

26. Liebeskind, L. S.; Baysdon, S. L.; Goedken, V.; Chidambaram, R.; Organometallics, 1986, 5, 1086.

27. Foland, L. D.; Decker, H. W.; Moore, H. W. J. Am. Chem. Soc. 1989, 111, 989-995.

28. South, M. S.; Liebeskind, L. S. J. Am. Chem. Soc. 1984, 106, 4181-4185.

29. Peterson, M. A.; Nilsson, B. L. Synth. Commun. 1999, 29, 3821-3827.

30. Mihoviloc, M.; Stanetty, P.; Koller, H. J. Org. Chem. 1992, 57, 6833-6837.

31. Lowary, T. L.; Krein, D. M. J. Org. Chem. 2002, 67, 4965-4967

32. Turner, J. J. Org. Chem. 1983, 48, 3401-3408.

33. Onoda, A.; Yamada, Y.; Takeda, J.; Nakayama, Y.; Okamura, T.; Doi, M.; Yamamoto, H.; Ueyama, N. Bull. Chem. Soc. Jpn. 2004, 77, 321-329.

34. Enhsen, A.; Karabelas, K.; Heerding, J. M.; Moore, H. W. J. Org. Chem. 1990, 55, 1177-1185.

35. Sapountzis, I.; Dube, H.; Lewis, R.; Gommermann, N.; Knochel, P. J. Org. Chem. 2005, 70, 2445-2454.

36. Chen, L.; Chen, G.; Tamborski, C. J. Organomet. Chem. 1980, 193, 283-292.

37. Liebeskind, L.; Iyer, S.; Jewell, C. J. Org. Chem. 1986, 51, 3067-3068.

38. Taylor, D.A; Baradaram, M.M., Martinez, S. J.; Joule, J.A. J. Chem. Res., Synop. 1979, 12, 387.

39. Cruces, J.; Estévez, J.C.; Castedo, L.; Estévez, R.J. Tetrahedron Lett. 2001, 42, 4825-4827.

40. Liebeskind, L. S.; Wirtz, K. R. J. Org. Chem. 1990, 55, 5350-5358. 
41. Tomooka, C. S.; Liu, H.; Moore, H. J. Org. Chem. 1996, 61, 6009-6012.

42. Talley, J.; Evans, I. J. Org. Chem. 1984, 49, 5267-5269.

43. Boymond, L.; Rottländer, M.; Cahiez, G.; Knochel, P. Angew. Chem., Int. Ed. 1998, 37, 17011703.

44. Silva, T. M.; Camara, C. A.; Barbosa, T. P.; Soares, A. Z.; Cunha, L. C. d.; Pinto, A. C.; Vargas, M. D. Bioorg. Med. Chem. 2005, 13, 193-196.

45. Wolfe, J. P.; Buchwald, S. L. J. Org. Chem. 2000, 65, 1144-1157.

46. Buchwald, S. L.; Zim, D. Org. Lett. 2003, 5, 2413-2415.

47. Guo, X.; Rao, H.; Fu, H.; Jiang, Y.; Zhao, Y. Adv. Synth. Catal. 2006, 348, 2197-2202.

48. Martínez, A.; Fernández, M.; Castedo, L.; Estévez, R. J.; Estévez, J. C. Tetrahedron 2005, 61, 1353-1362.

49. Chai, C. L.; Elix, J. A.; Moore, F. K. Tetrahedron Lett. 2001, 42, 8915-8917. 


\section{Appendix}




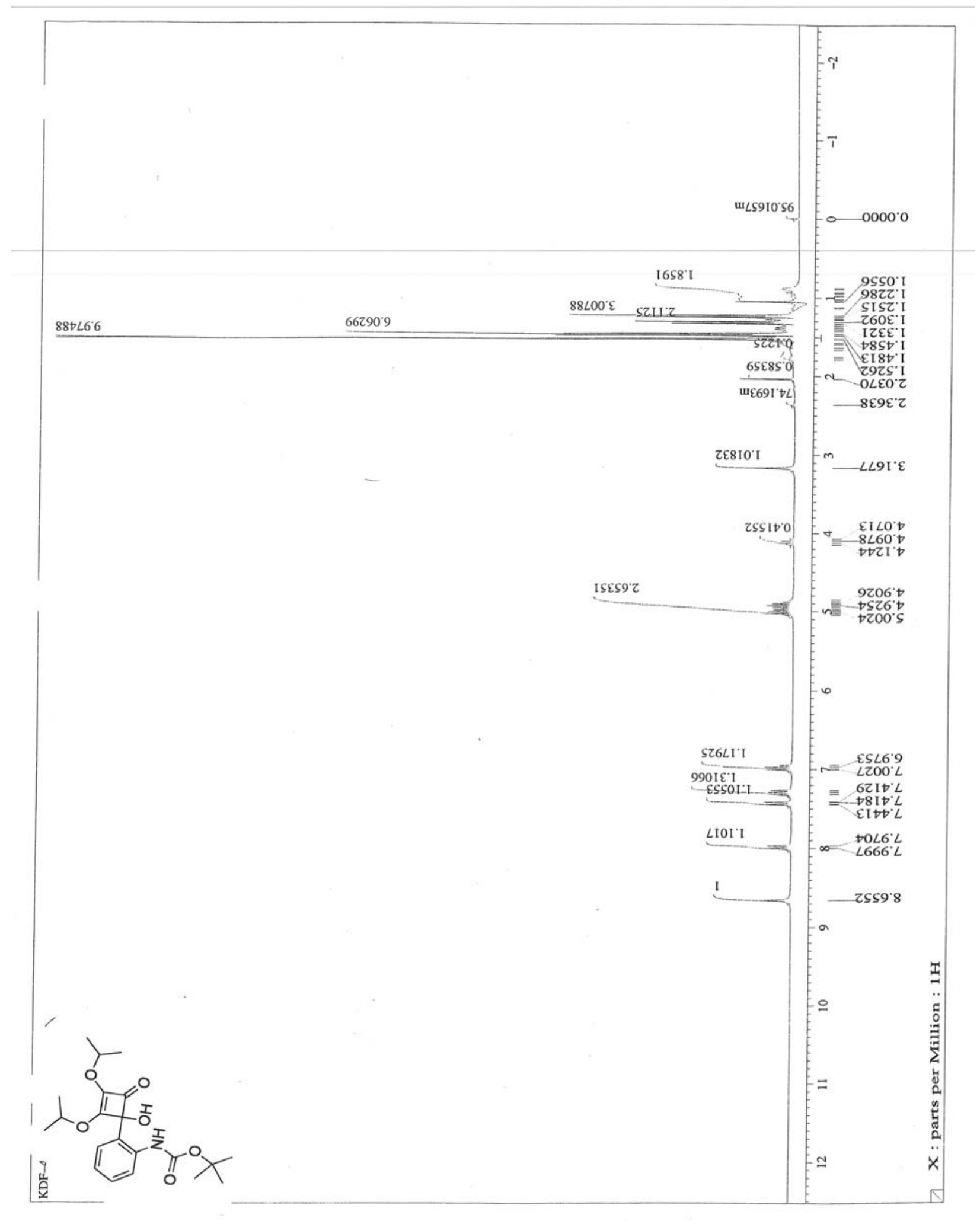

${ }^{1}$ H NMR tert-Butyl 2-(1-hydroxy-2,3-diisopropoxy-4-oxocyclobut-2-enyl)phenylcarbamate (5) 


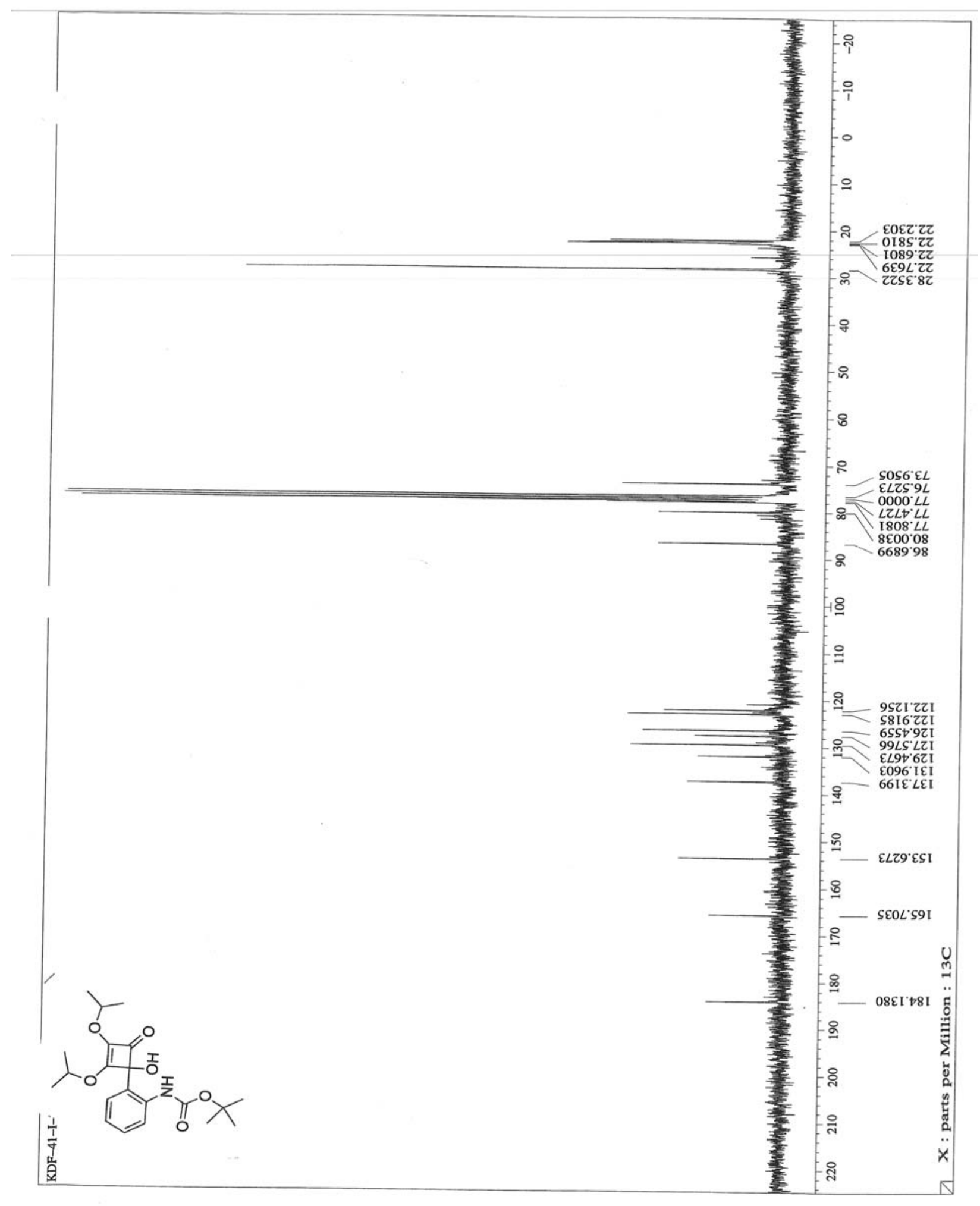

${ }^{13}$ C NMR tert-Butyl 2-(1-hydroxy-2,3-diisopropoxy-4-oxocyclobut-2-enyl)phenylcarbamate (5) 


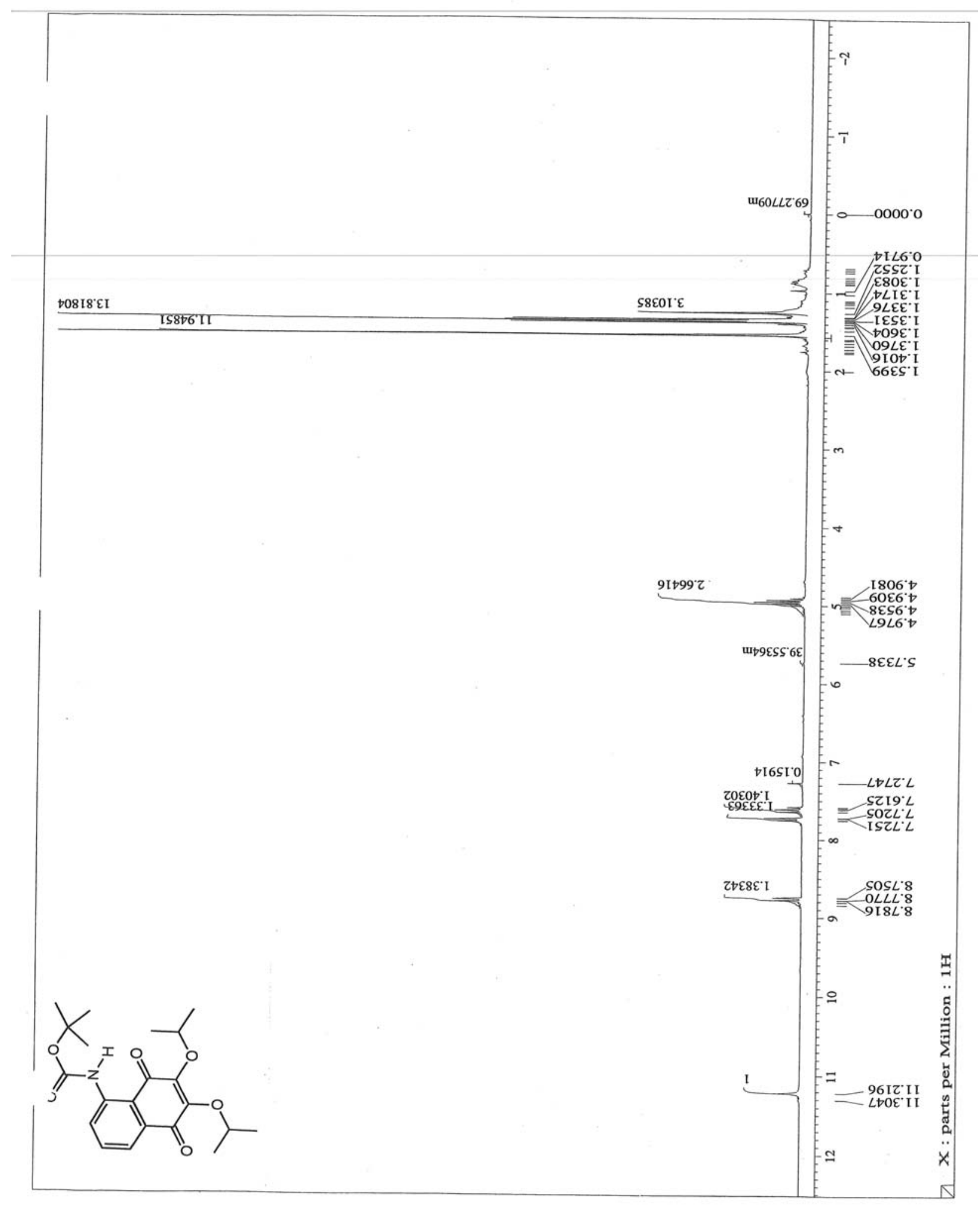

${ }^{1} \mathrm{H}$ NMR tert-Butyl 1,4-dihydro-2,3-diisopropoxy-1,4-dioxonaphthalen-5-ylcarbamate (6) 


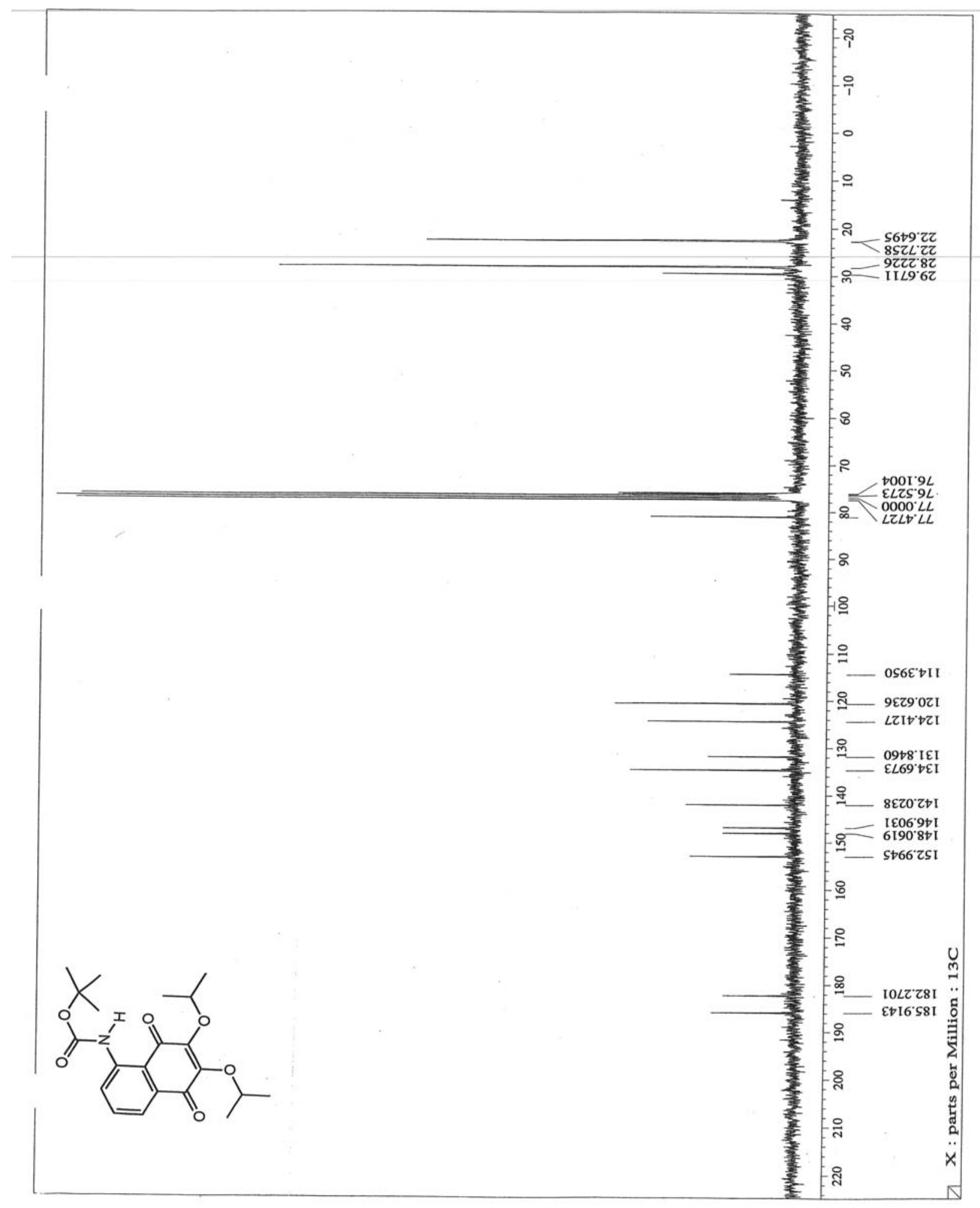

${ }^{13}$ C NMR tert-Butyl 1,4-dihydro-2,3-diisopropoxy-1,4-dioxonaphthalen-5-ylcarbamate (6) 


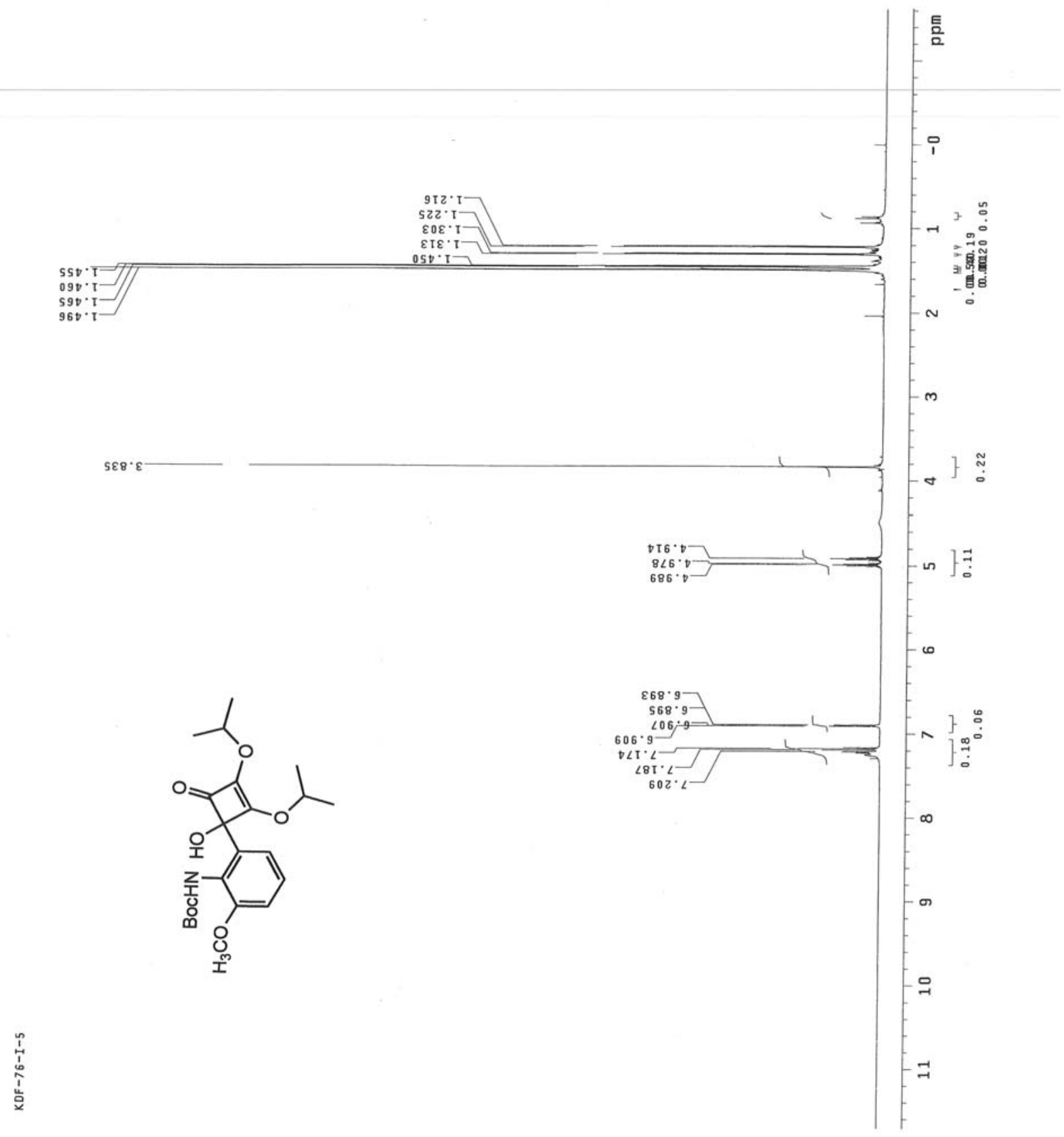

${ }^{1}$ H NMR tert-Butyl 2-(1-hydroxy-2,3-diisopropoxy-4-oxocyclobut-2-enyl)-6methoxyphenylcarbamate (10) 


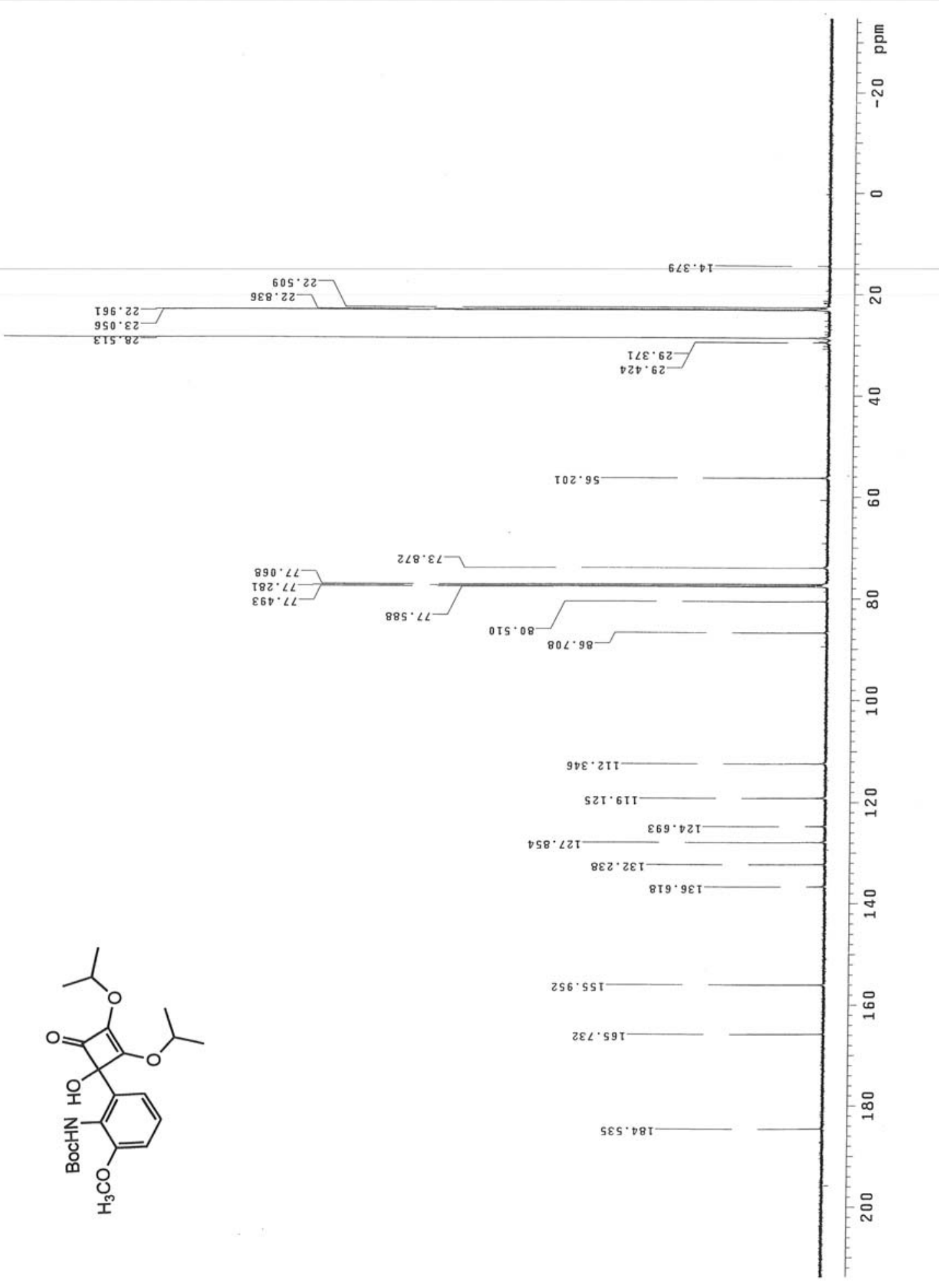

${ }^{13}$ C NMR tert-Butyl 2-(1-hydroxy-2,3-diisopropoxy-4-oxocyclobut-2-enyl)-6methoxyphenylcarbamate (10) 


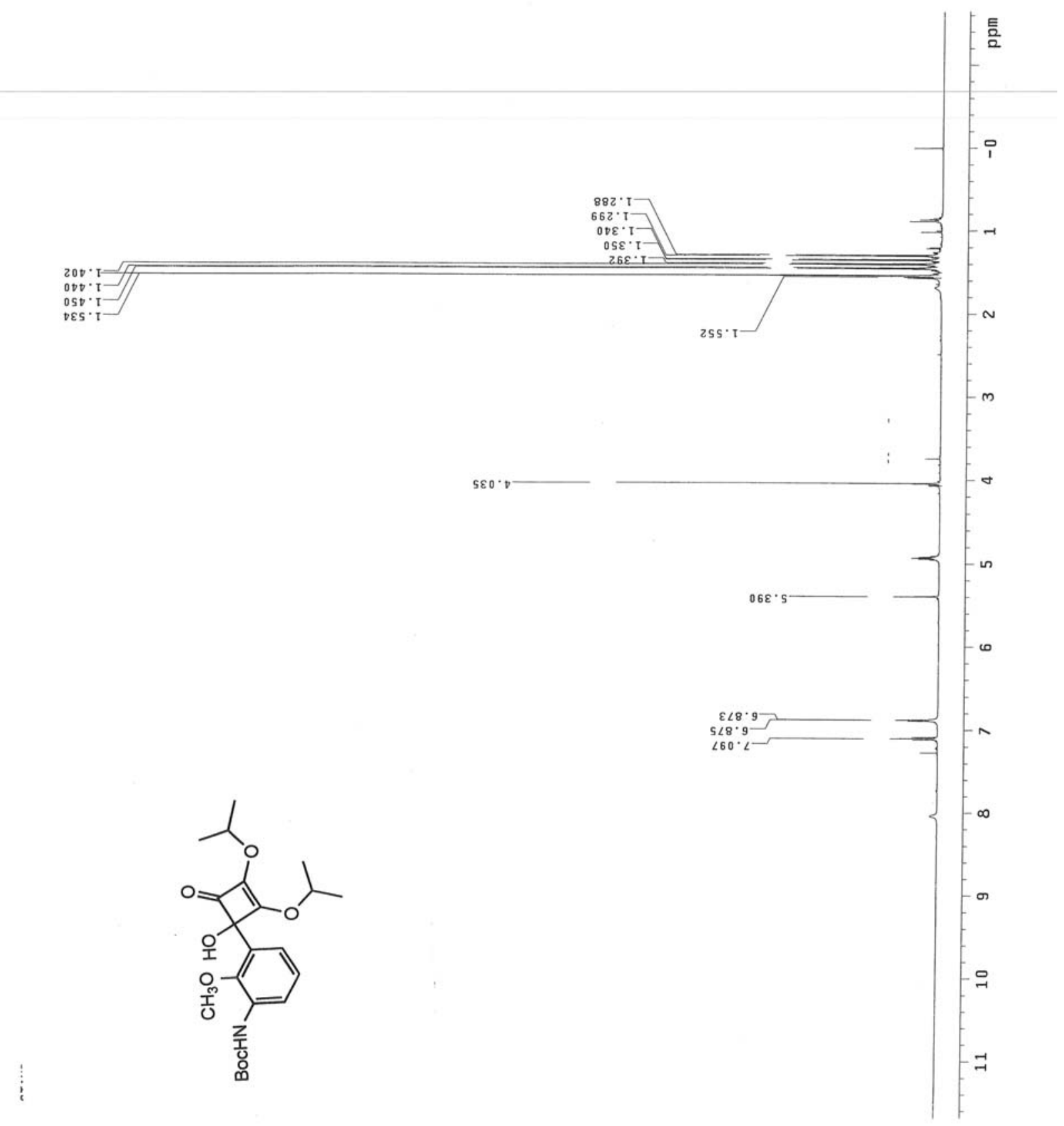

${ }^{1}$ H NMR tert-Butyl 3-(1-hydroxy-2,3-diisopropoxy-4-oxocyclobut-2-enyl)-2methoxyphenylcarbamate(11) 


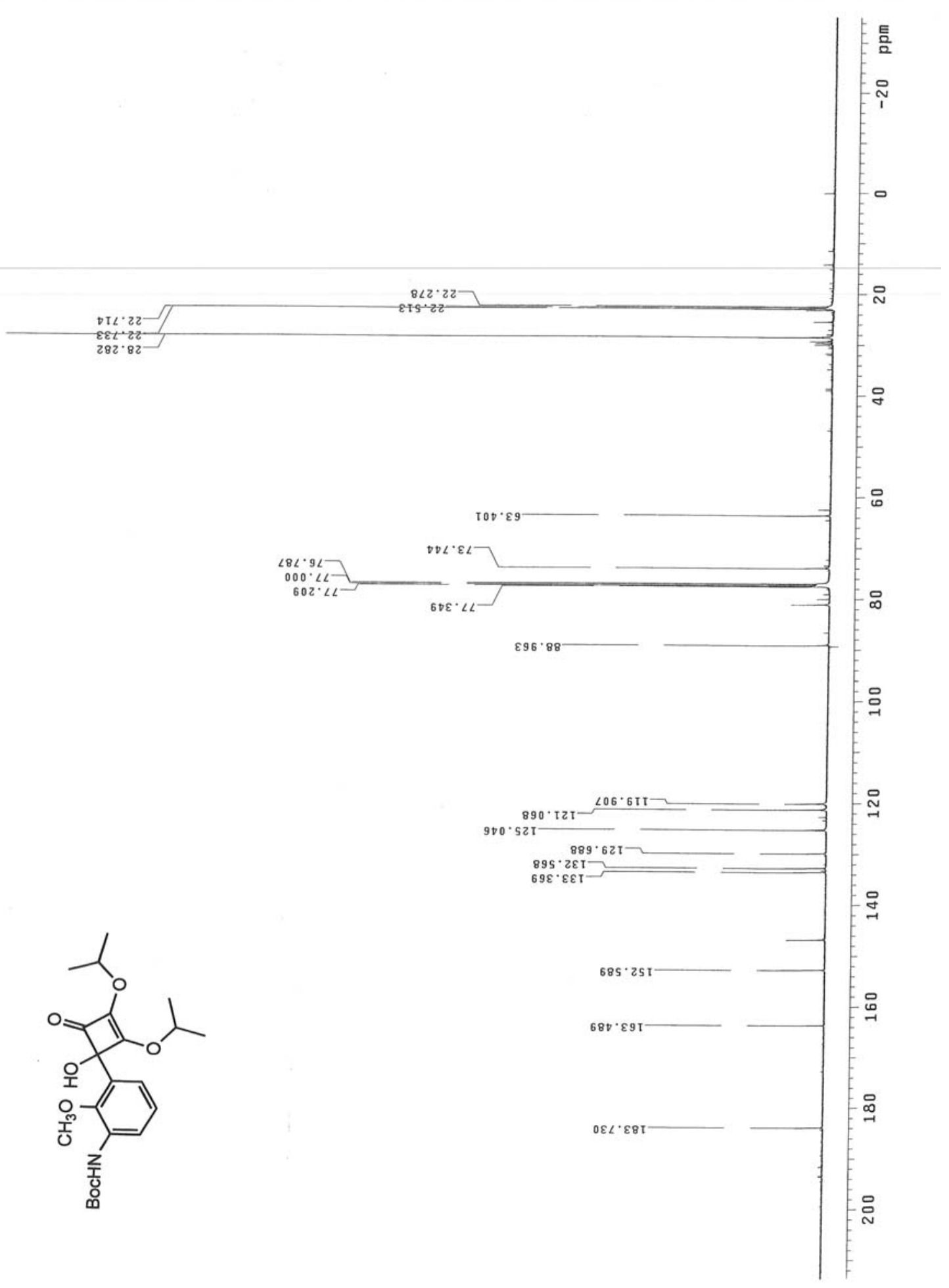

${ }^{13}$ C NMR tert-Butyl 3-(1-hydroxy-2,3-diisopropoxy-4-oxocyclobut-2-enyl)-2methoxyphenylcarbamate(11) 


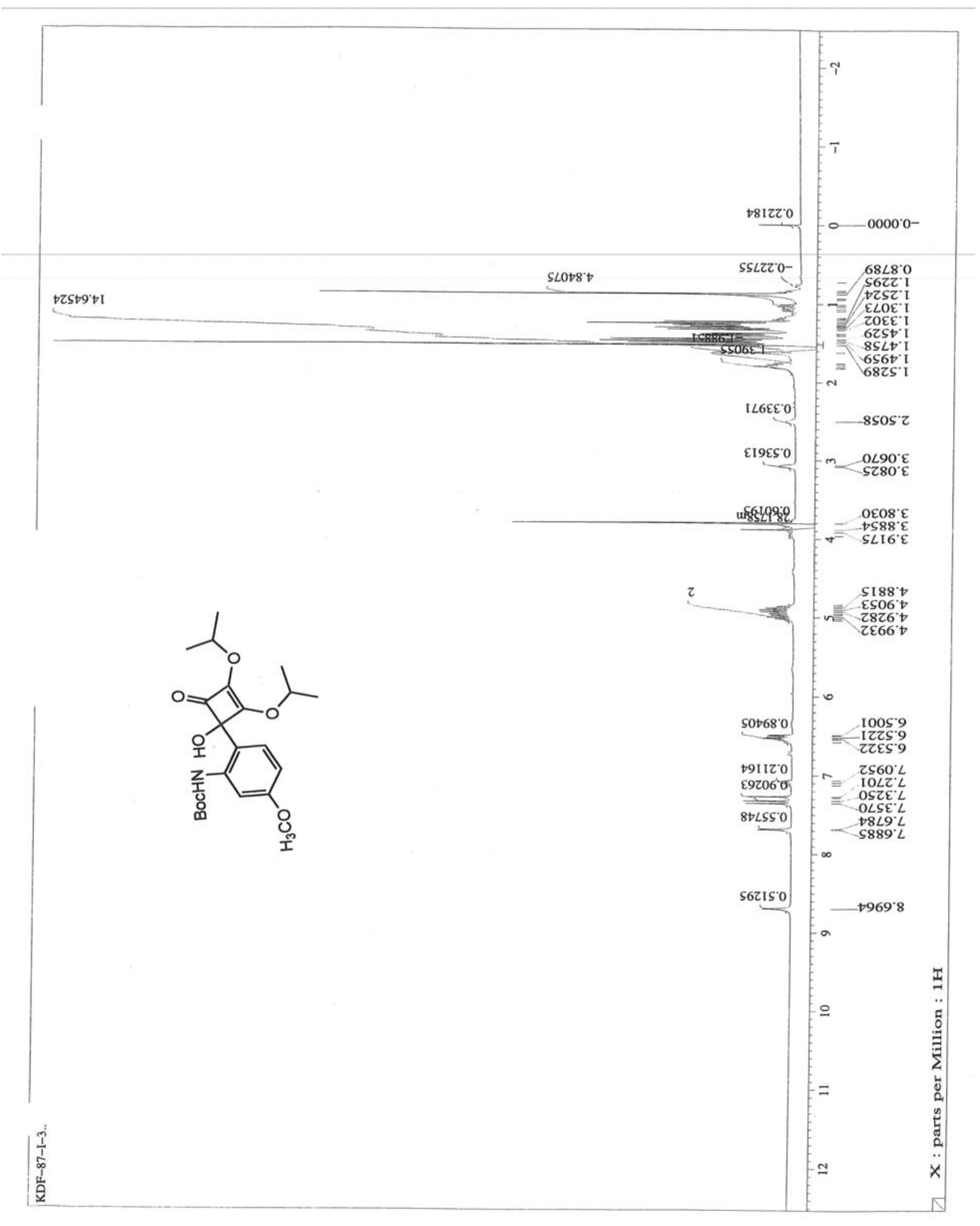

${ }^{1} \mathrm{H}$ NMR tert-Butyl 2-(1-hydroxy-2,3-diisopropoxy-4-oxocyclobut-2-enyl)-5methoxyphenylcarbamate (12) 


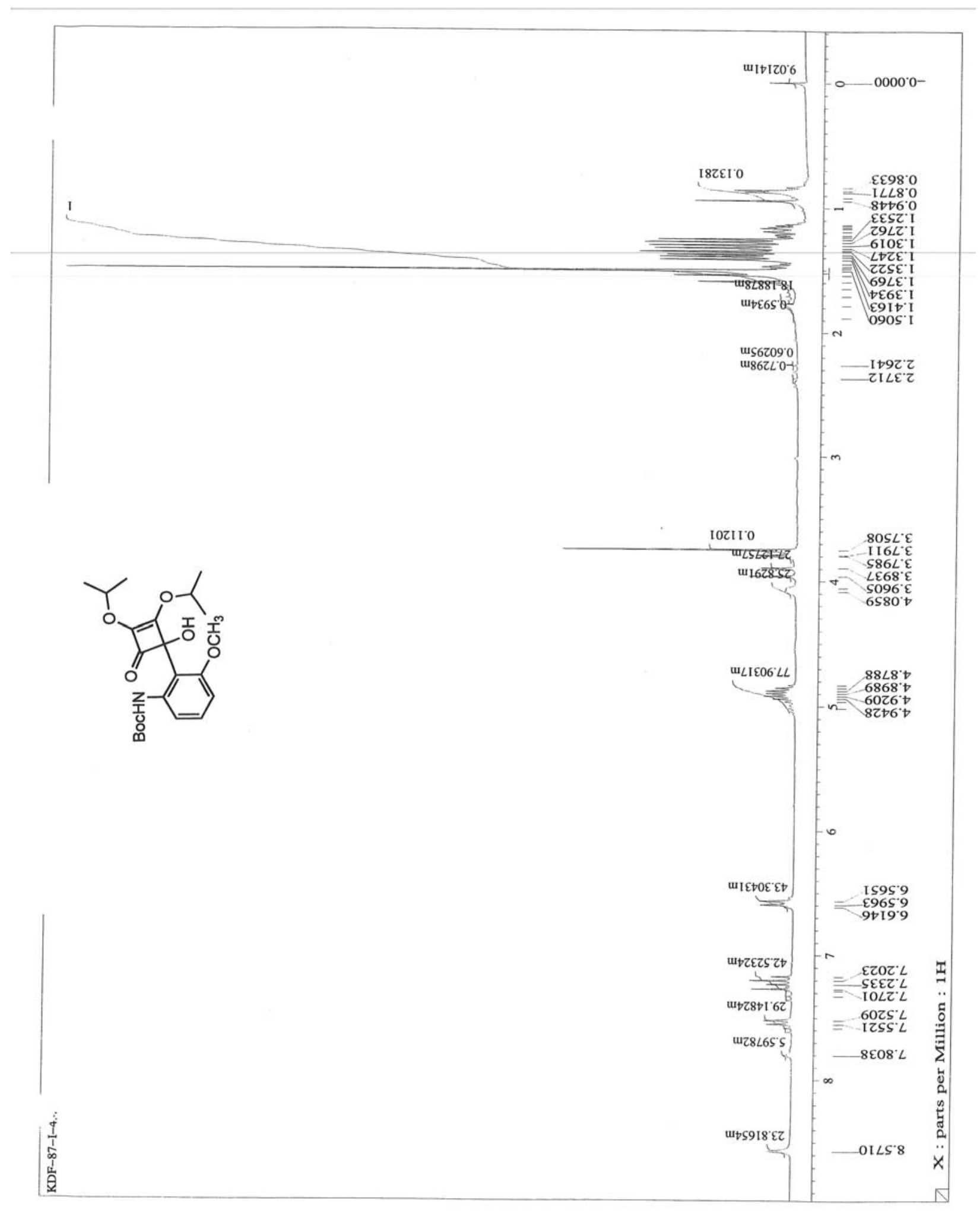

${ }^{1}$ H NMR tert-Butyl 2-(1-hydroxy-2,3-diisopropoxy-4-oxocyclobut-2-enyl)-3methoxyphenylcarbamate (14) 


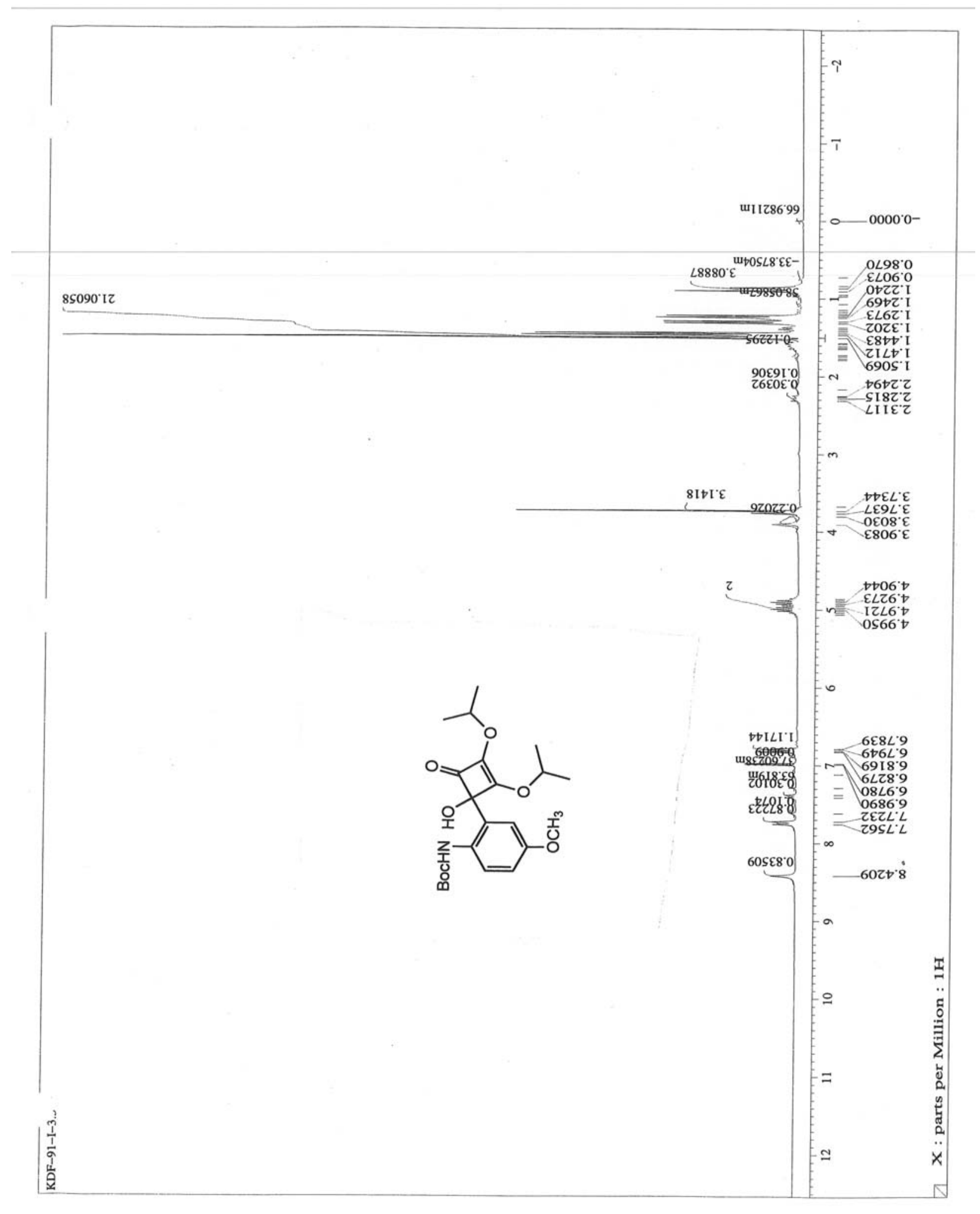

${ }^{1}$ H NMR tert-Butyl 2-(1-hydroxy-2,3-diisopropoxy-4-oxocyclobut-2-enyl)-4methoxyphenylcarbamate (15) 


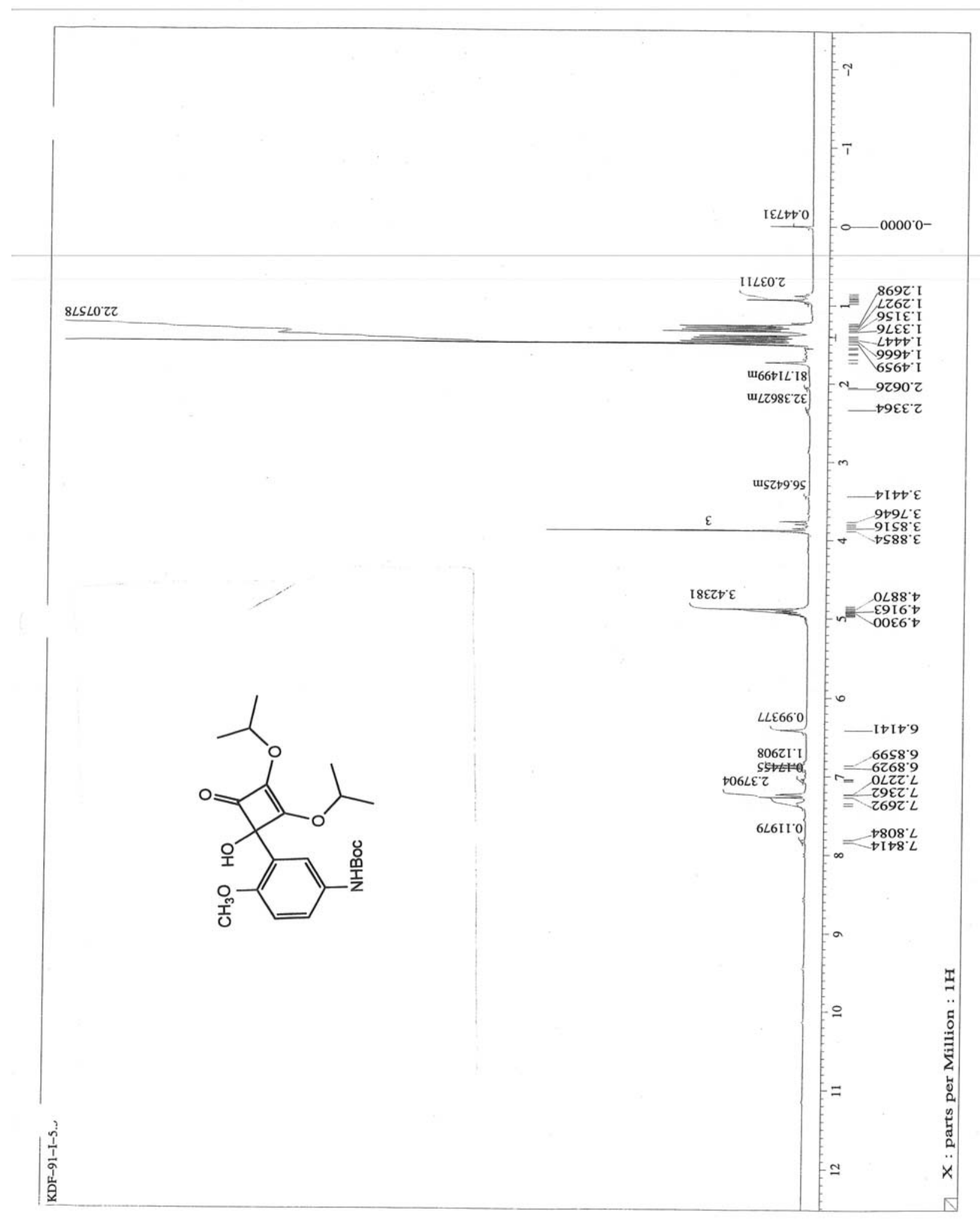

${ }^{1} \mathrm{H}$ NMR tert-Butyl 3-(1-hydroxy-2,3-diisopropoxy-4-oxocyclobut-2-enyl)-4methoxyphenylcarbamate (16) 


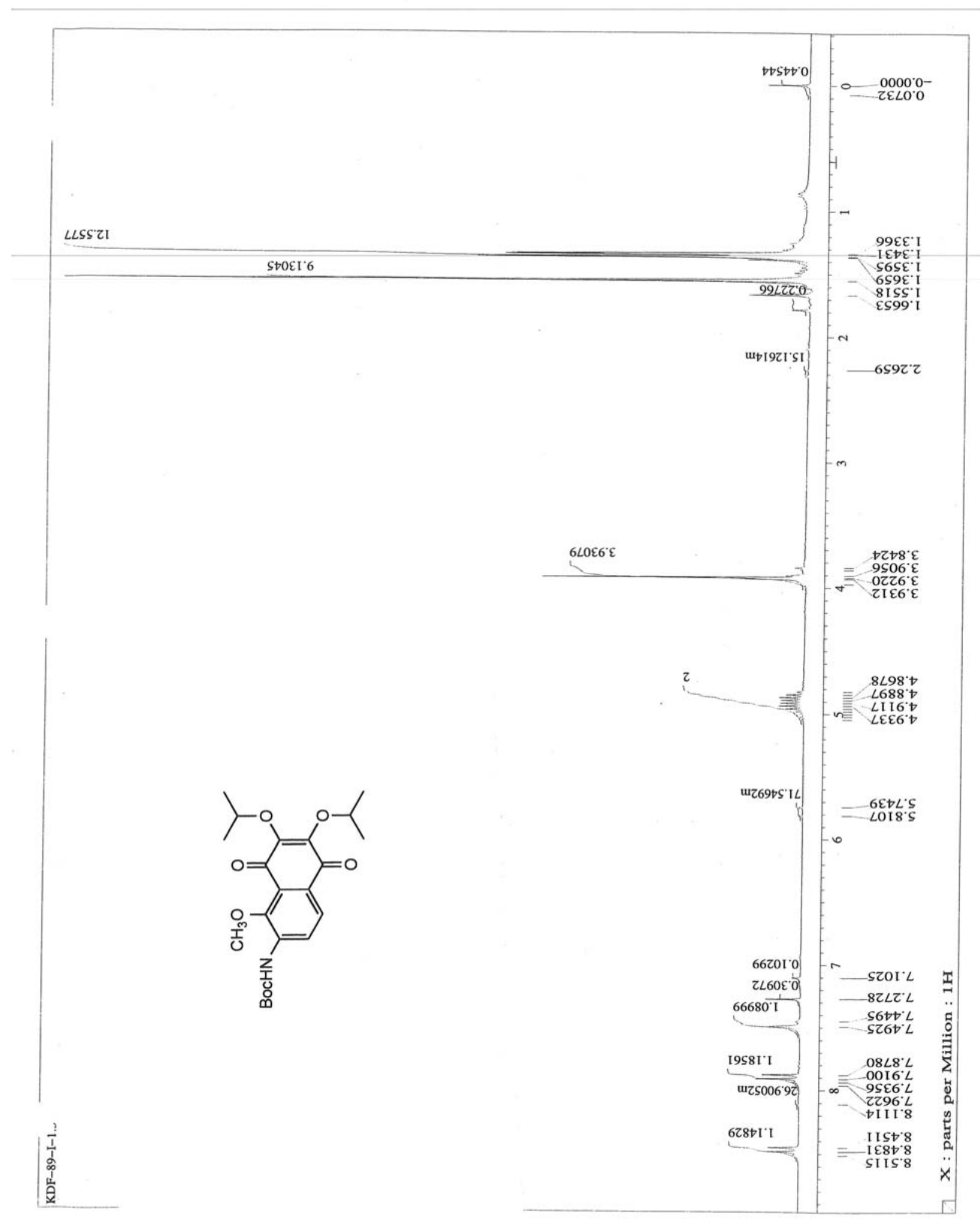

${ }^{1} \mathrm{H}$ NMR tert-Butyl 1,4-dihydro-2,3-diisopropoxy-5-methoxy-1,4-dioxonaphthalen-6ylcarbamate (18) 


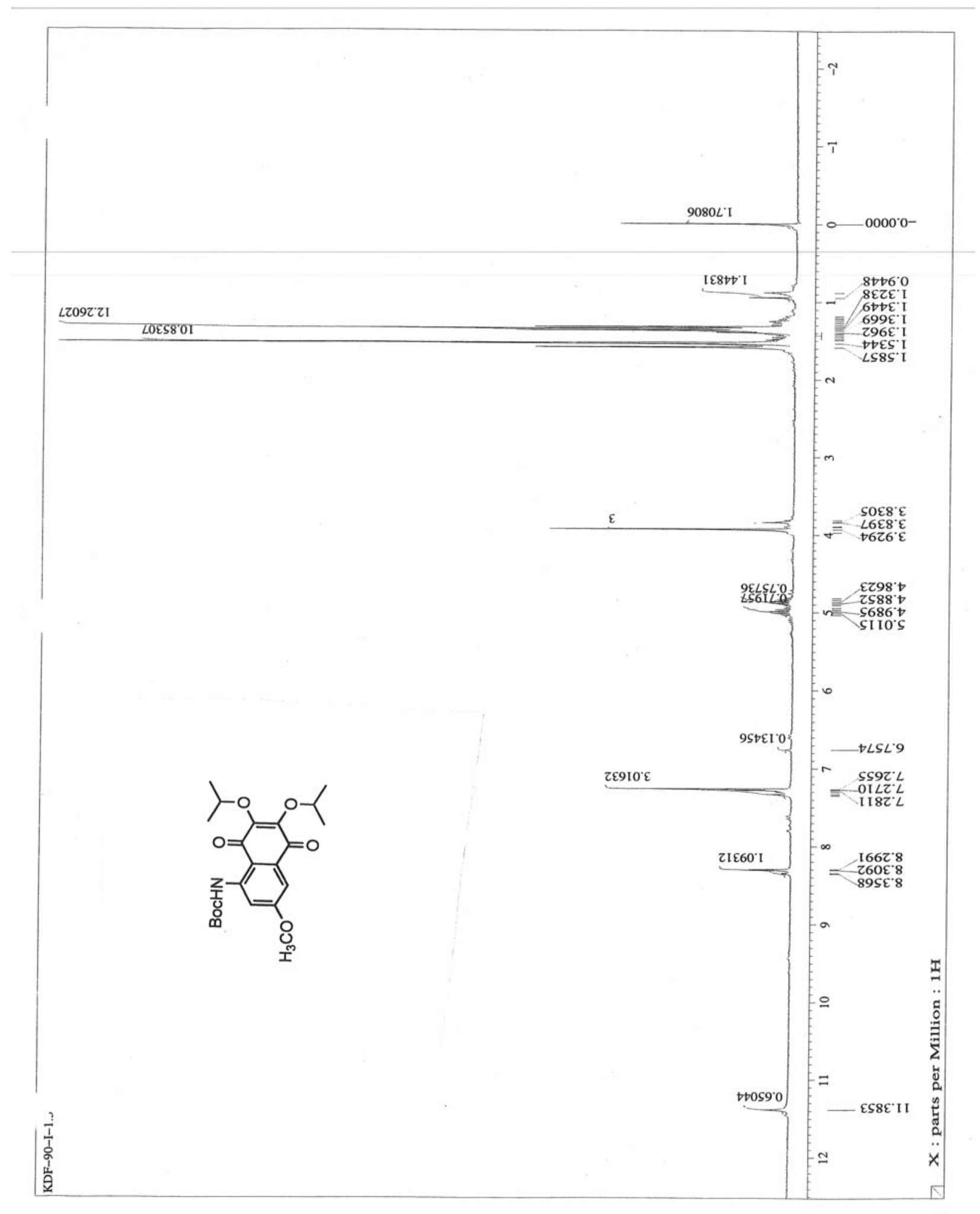

${ }^{1}$ H NMR tert-Butyl 1,4-dihydro-2,3-diisopropoxy-6-methoxy-1,4-dioxonaphthalen-8ylcarbamate (19) 


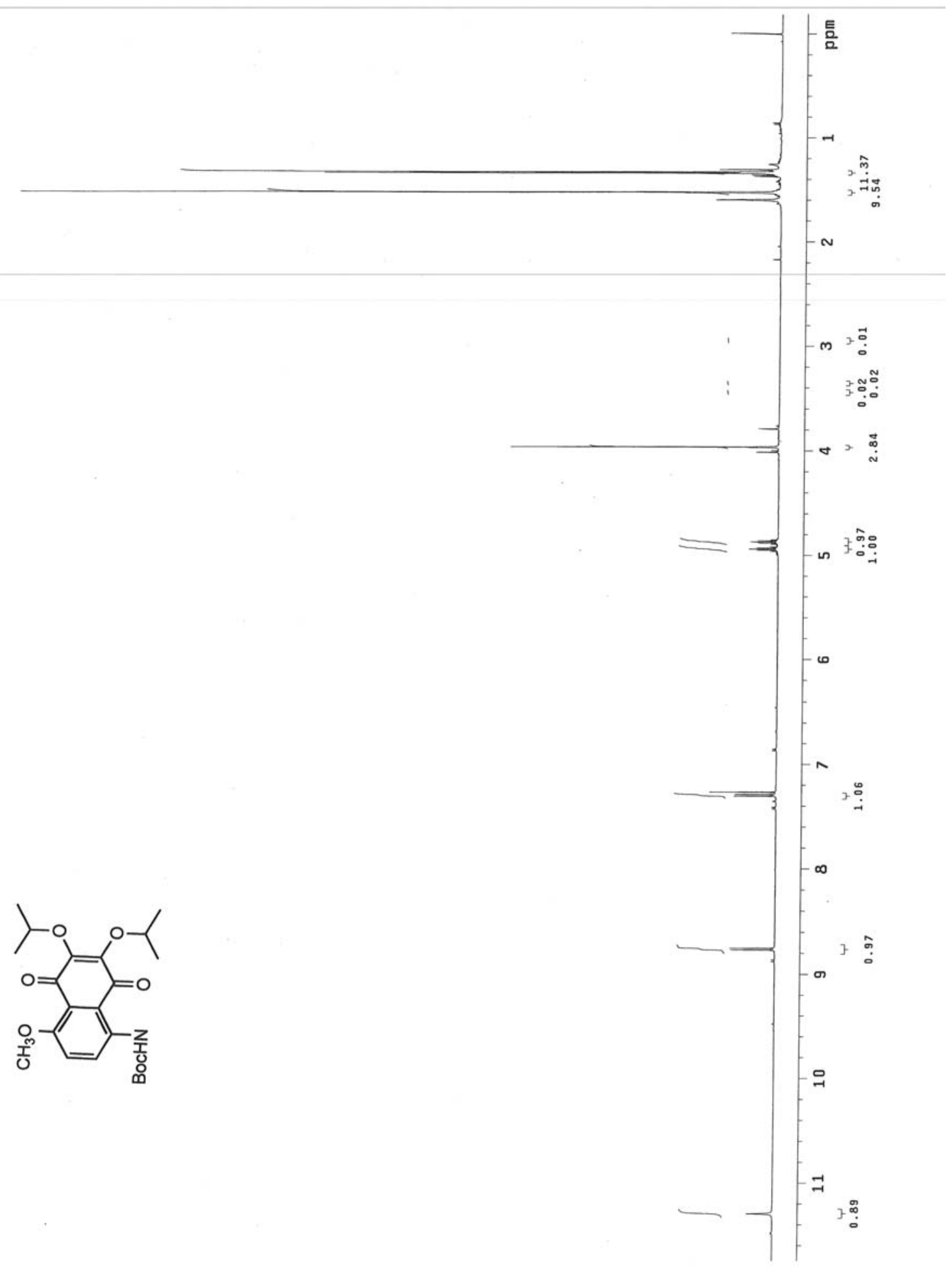

${ }^{1}$ H NMR tert-Butyl 1,4-dihydro-2,3-diisopropoxy-5-methoxy-1,4-dioxonaphthalen-8ylcarbamate (20) 


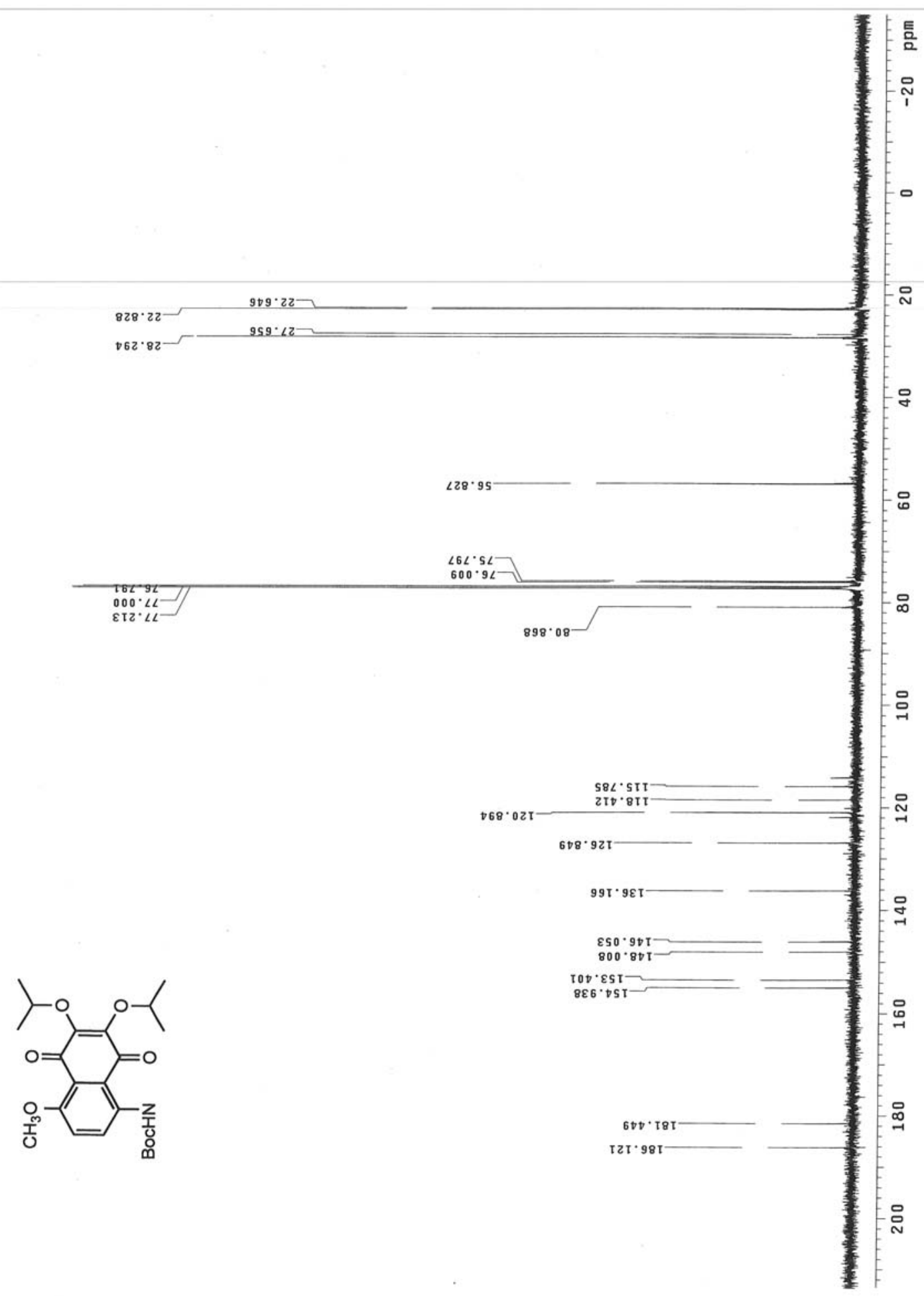

${ }^{13}$ C NMR tert-Butyl 1,4-dihydro-2,3-diisopropoxy-5-methoxy-1,4-dioxonaphthalen-8ylcarbamate (20) 


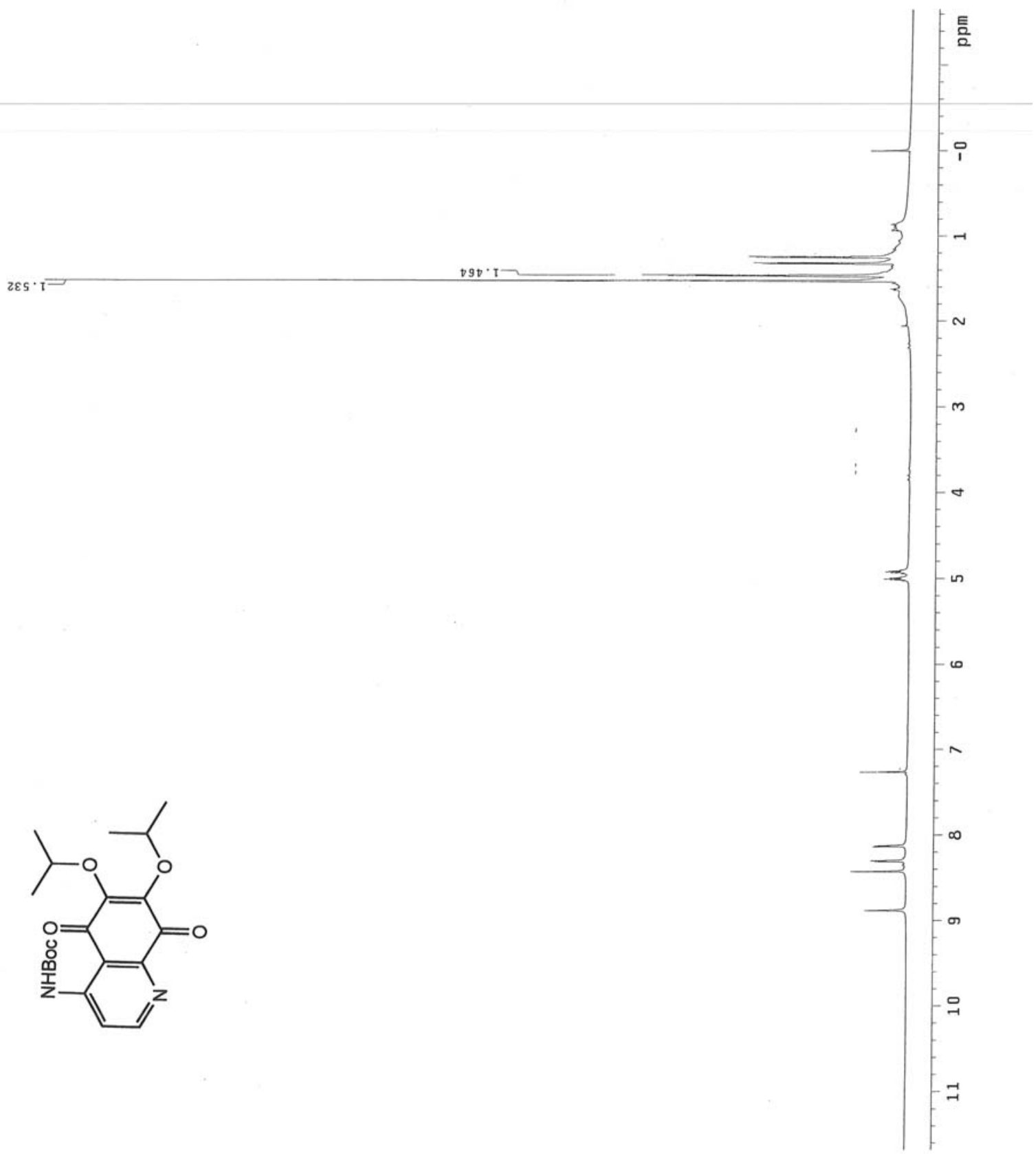

${ }^{1}$ H NMR tert-Butyl 5,8-dihydro-6,7-diisopropoxy-5,8-dioxoquinolin-4-ylcarbamate (27) 


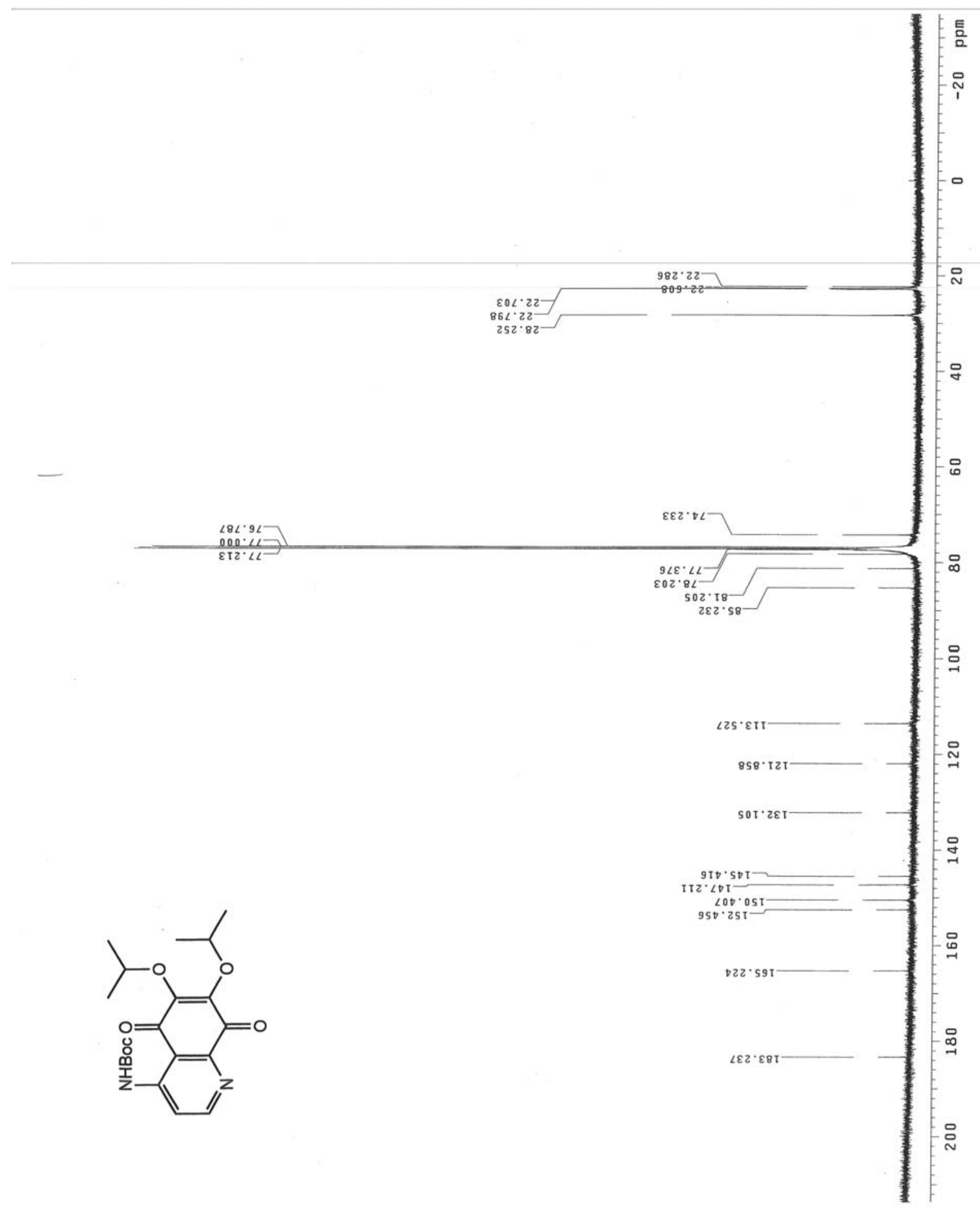

${ }^{13}$ C NMR tert-Butyl 5,8-dihydro-6,7-diisopropoxy-5,8-dioxoquinolin-4-ylcarbamate (27) 


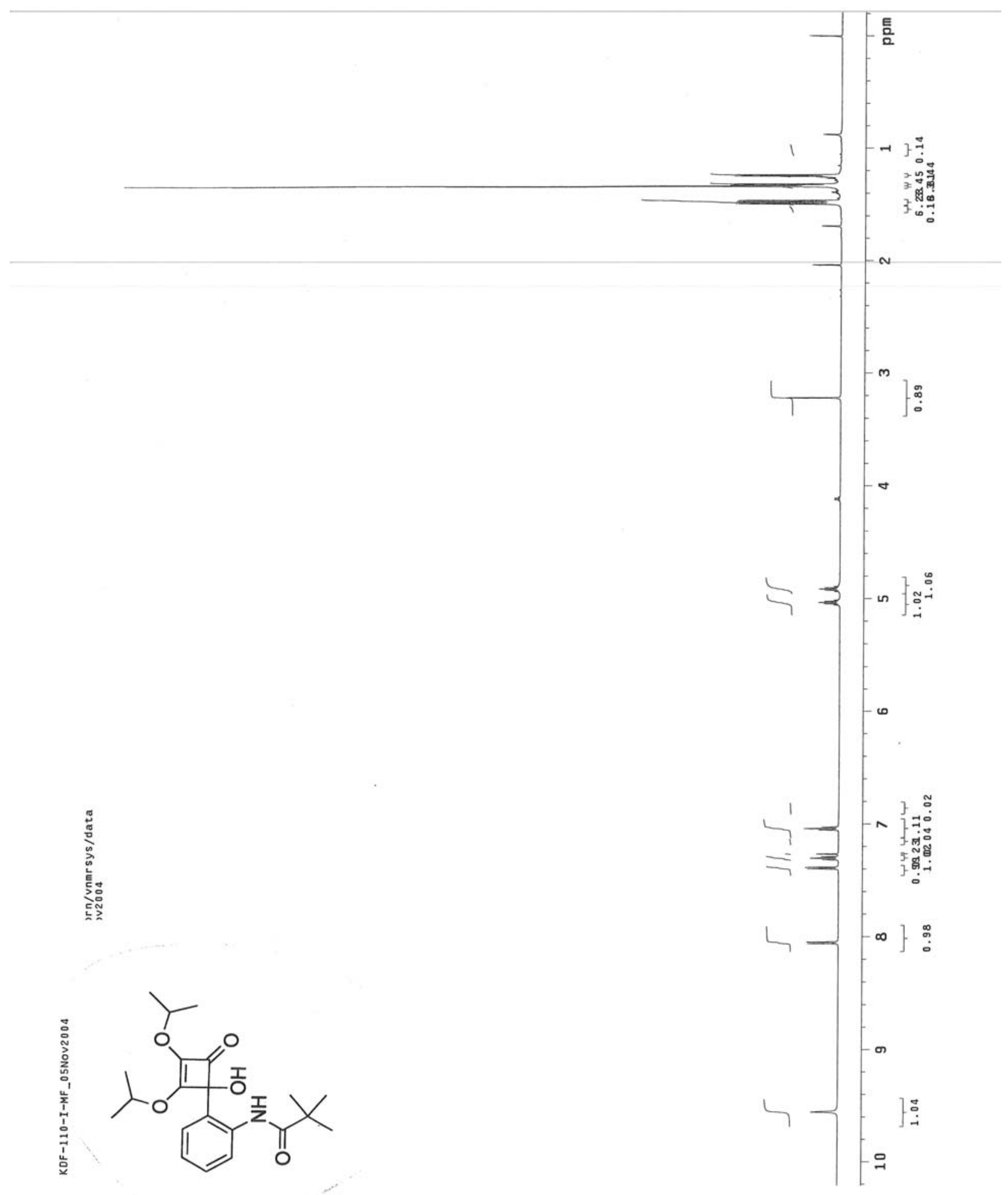

${ }^{1}$ H NMR N-(2-(1-hydroxy-2,3-diisopropoxy-4-oxocyclobut-2-enyl)phenyl)pivalamide (36) 


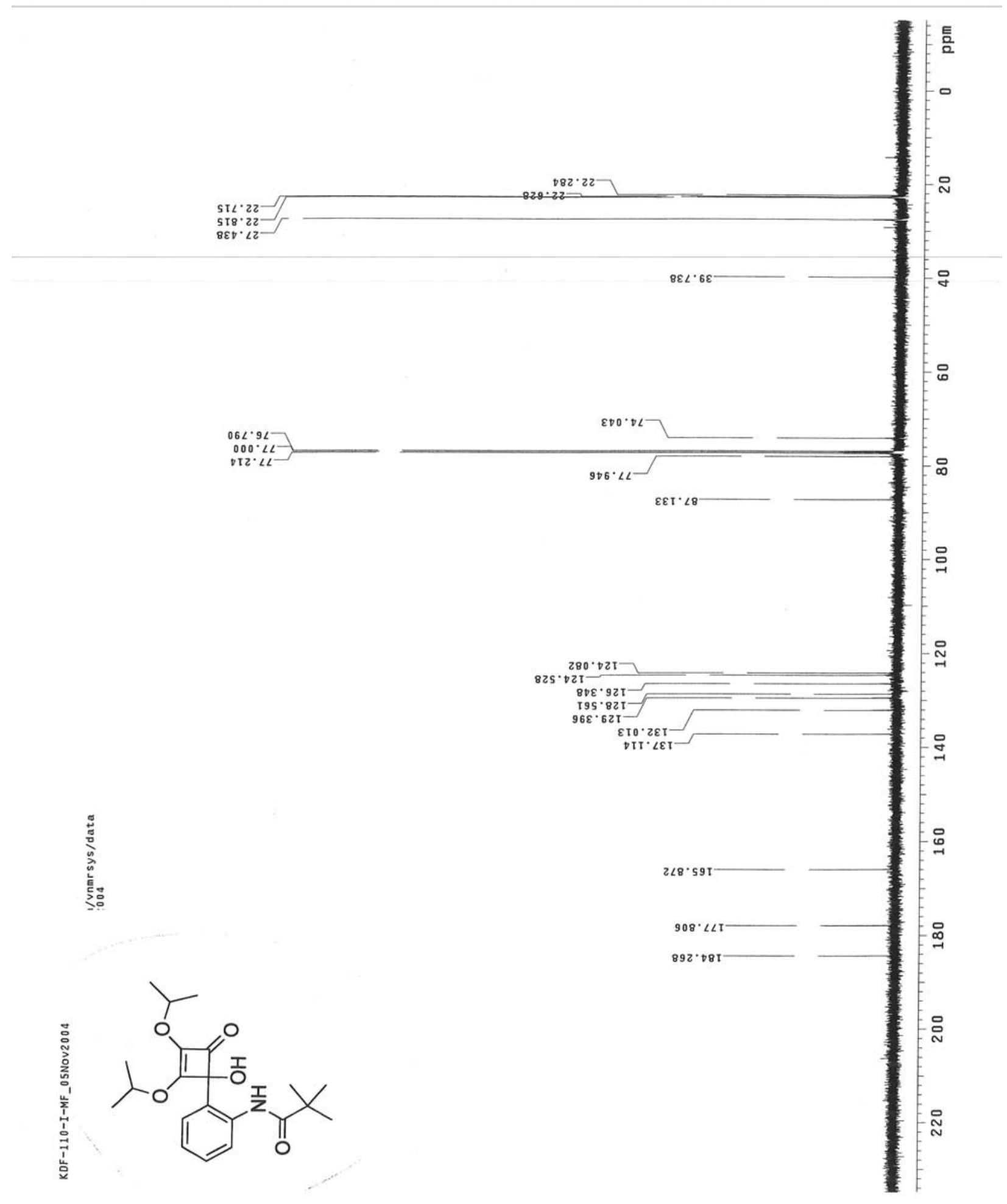

${ }^{13}$ C NMR N-(2-(1-hydroxy-2,3-diisopropoxy-4-oxocyclobut-2-enyl)phenyl)pivalamide (36) 


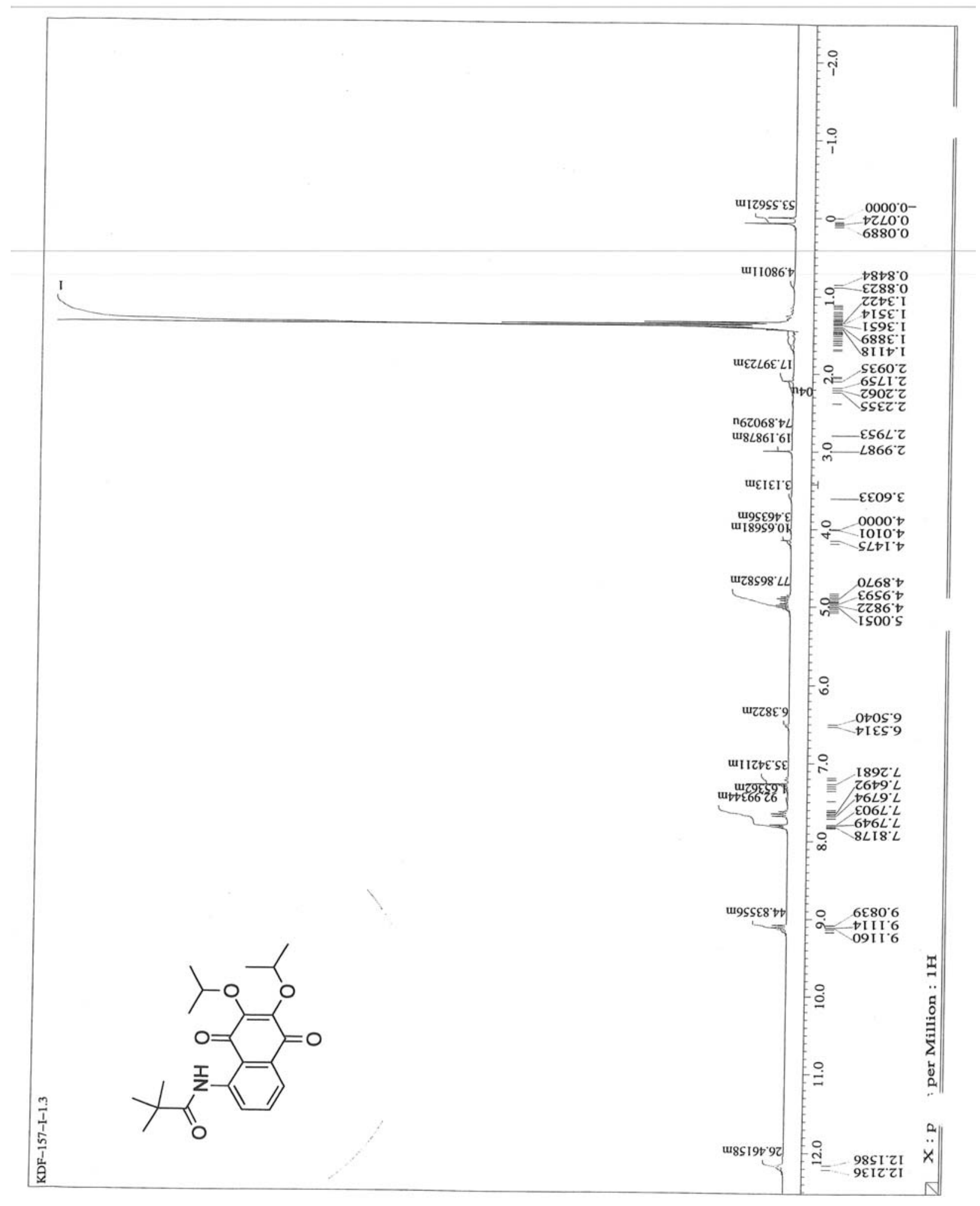

${ }^{1} \mathrm{H}$ NMR N-(1,4-dihydro-2,3-diisopropoxy-1,4-dioxonaphthalen-5-yl)pivalamide (37) 


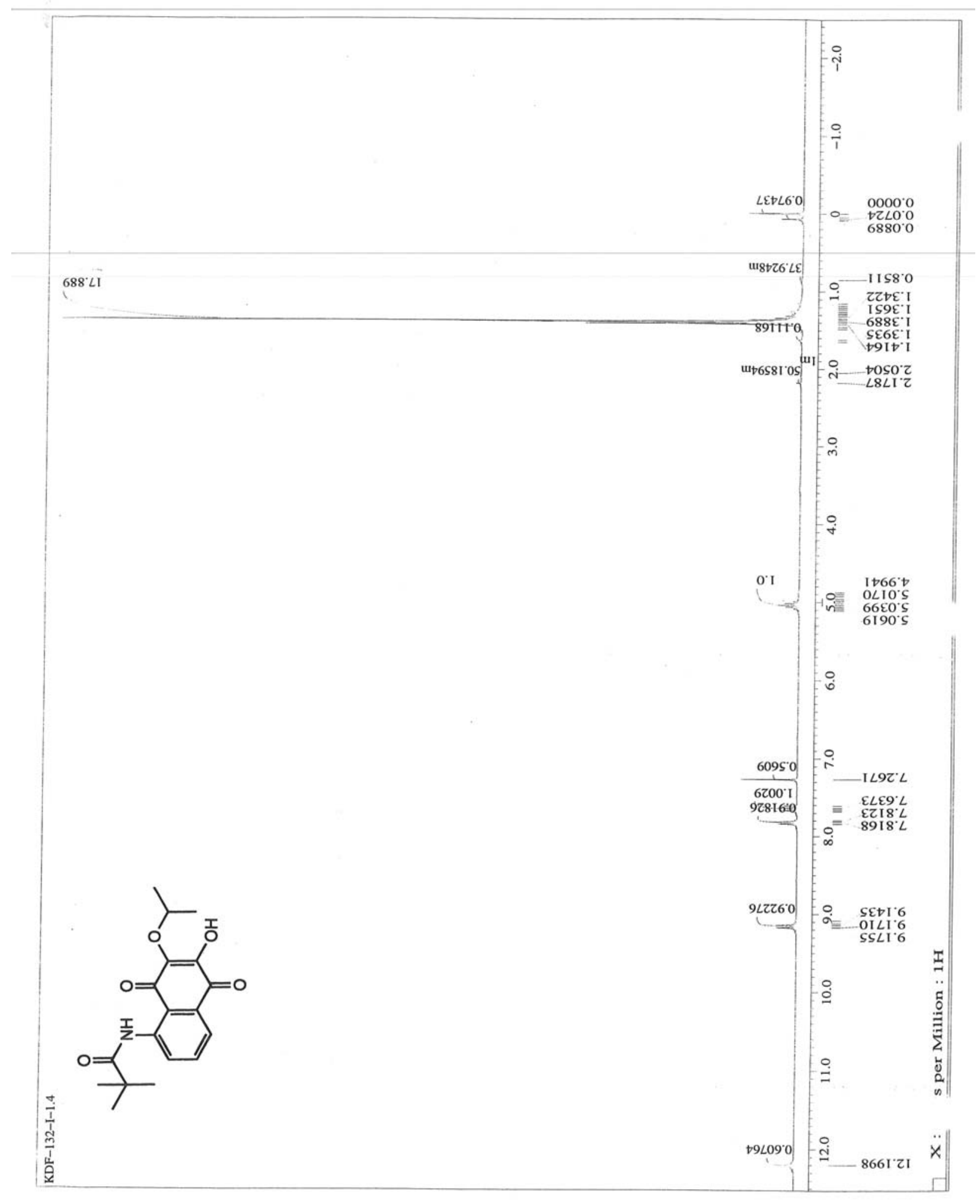

${ }^{1} \mathrm{H}$ NMR N-(1,4-dihydro-2-hydroxy-3-isopropoxy-1,4-dioxonaphthalen-5-yl)pivalamide (38) 


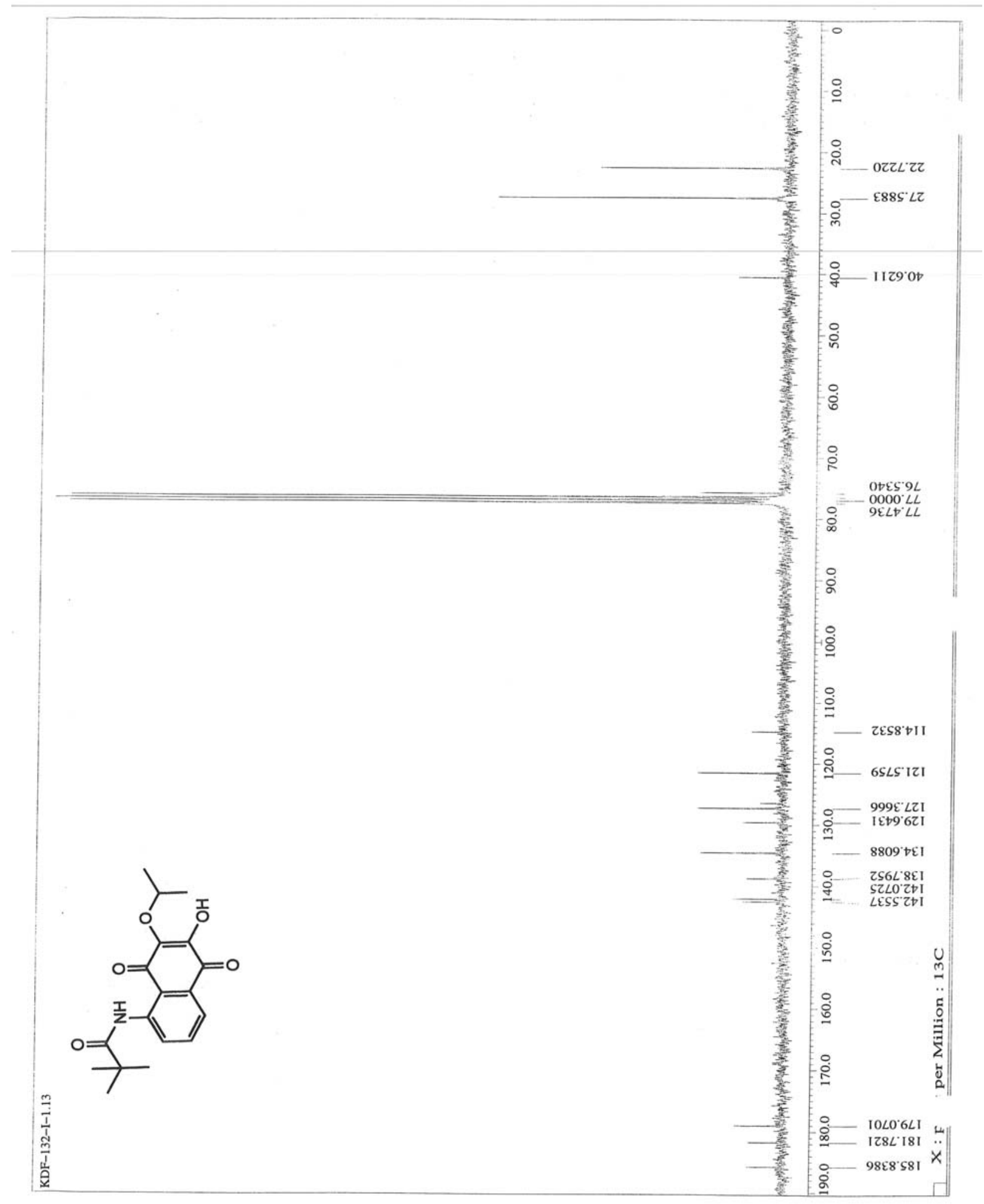

${ }^{13}$ C NMR N-(1,4-dihydro-2-hydroxy-3-isopropoxy-1,4-dioxonaphthalen-5-yl)pivalamide (38) 


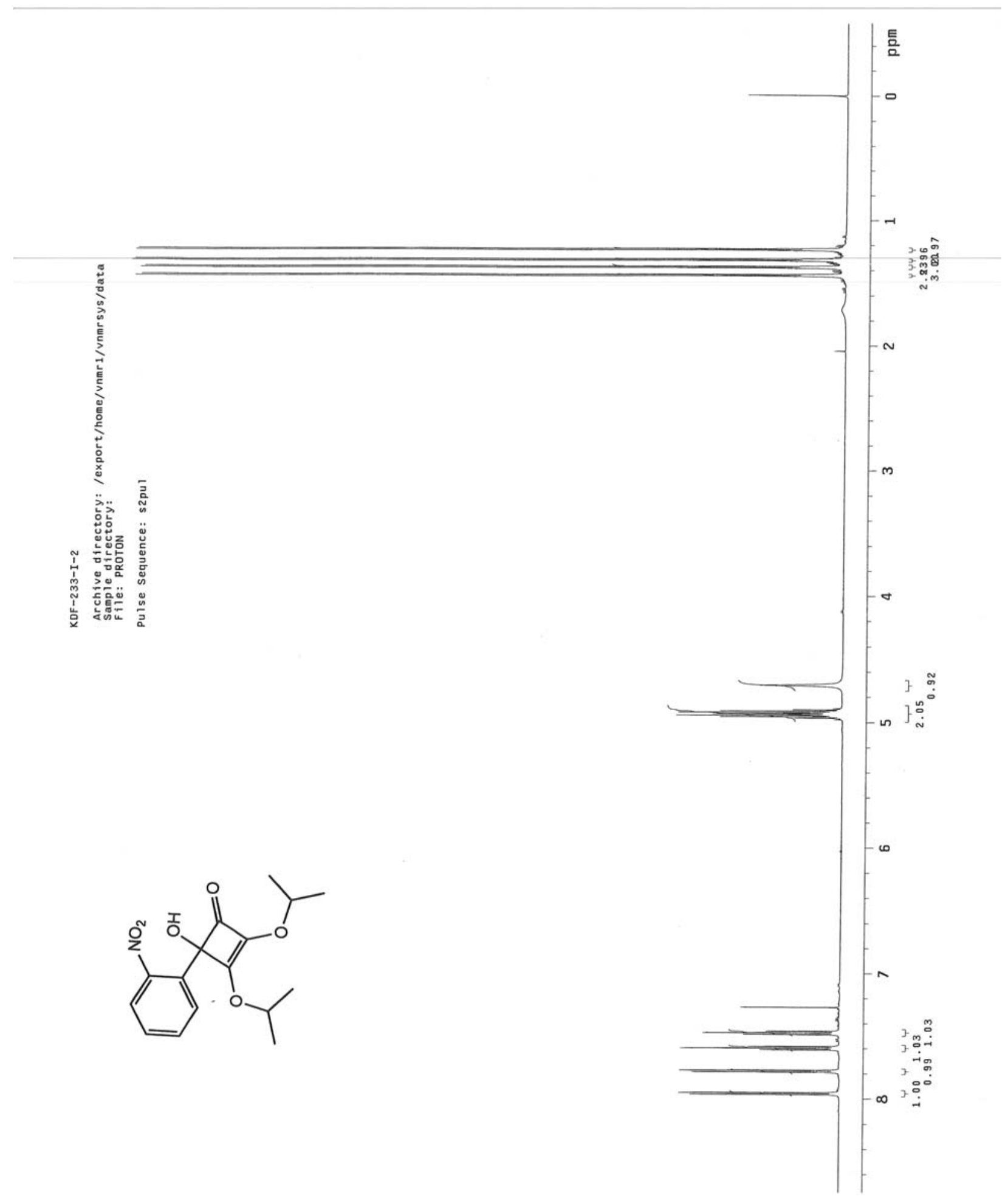

${ }^{1}$ H NMR 4-hydroxy-2,3-diisopropoxy-4-(2-nitrophenyl)cyclobut-2-enone (39) 


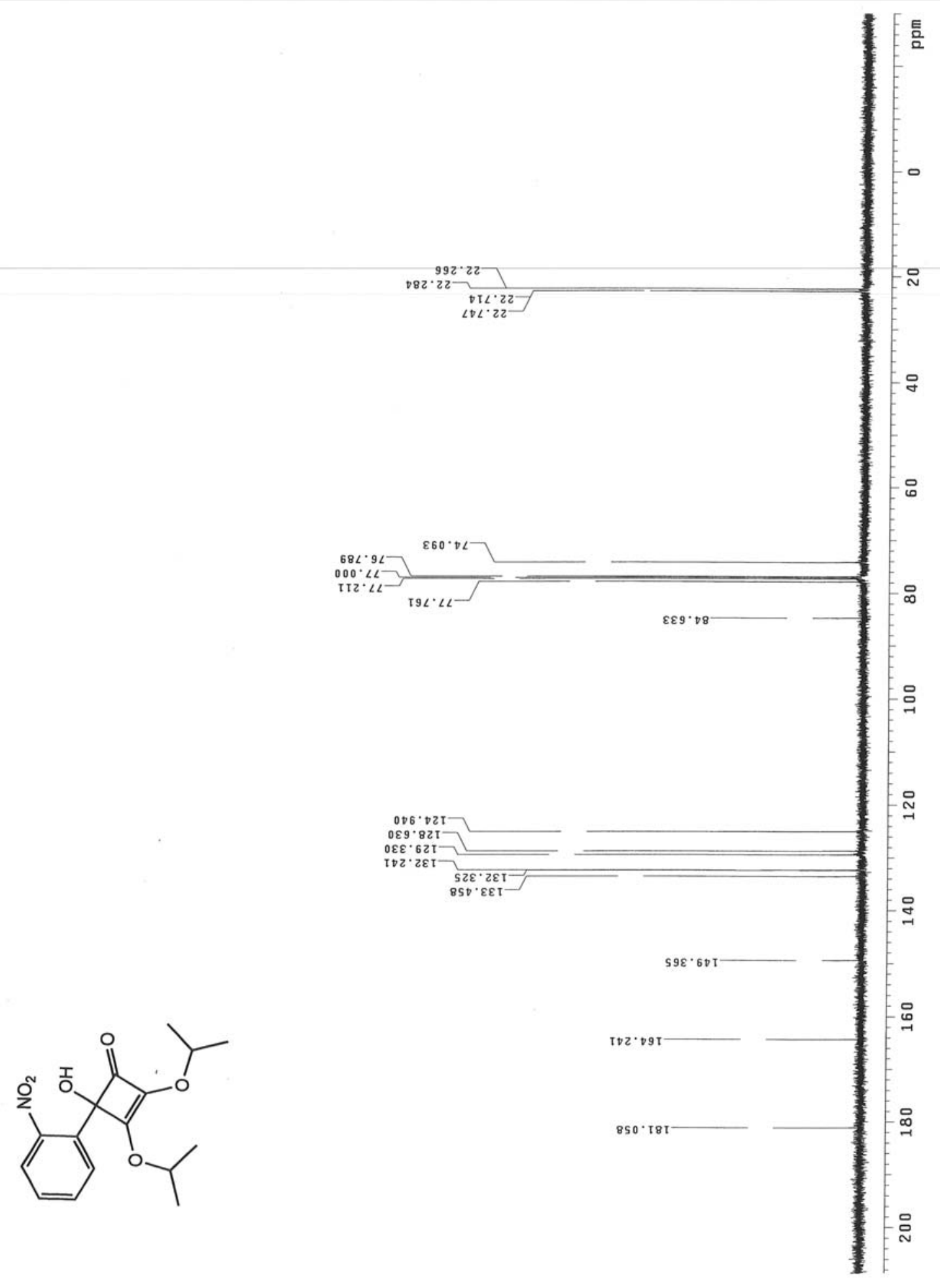

${ }^{13}$ C NMR 4-hydroxy-2,3-diisopropoxy-4-(2-nitrophenyl)cyclobut-2-enone (39) 


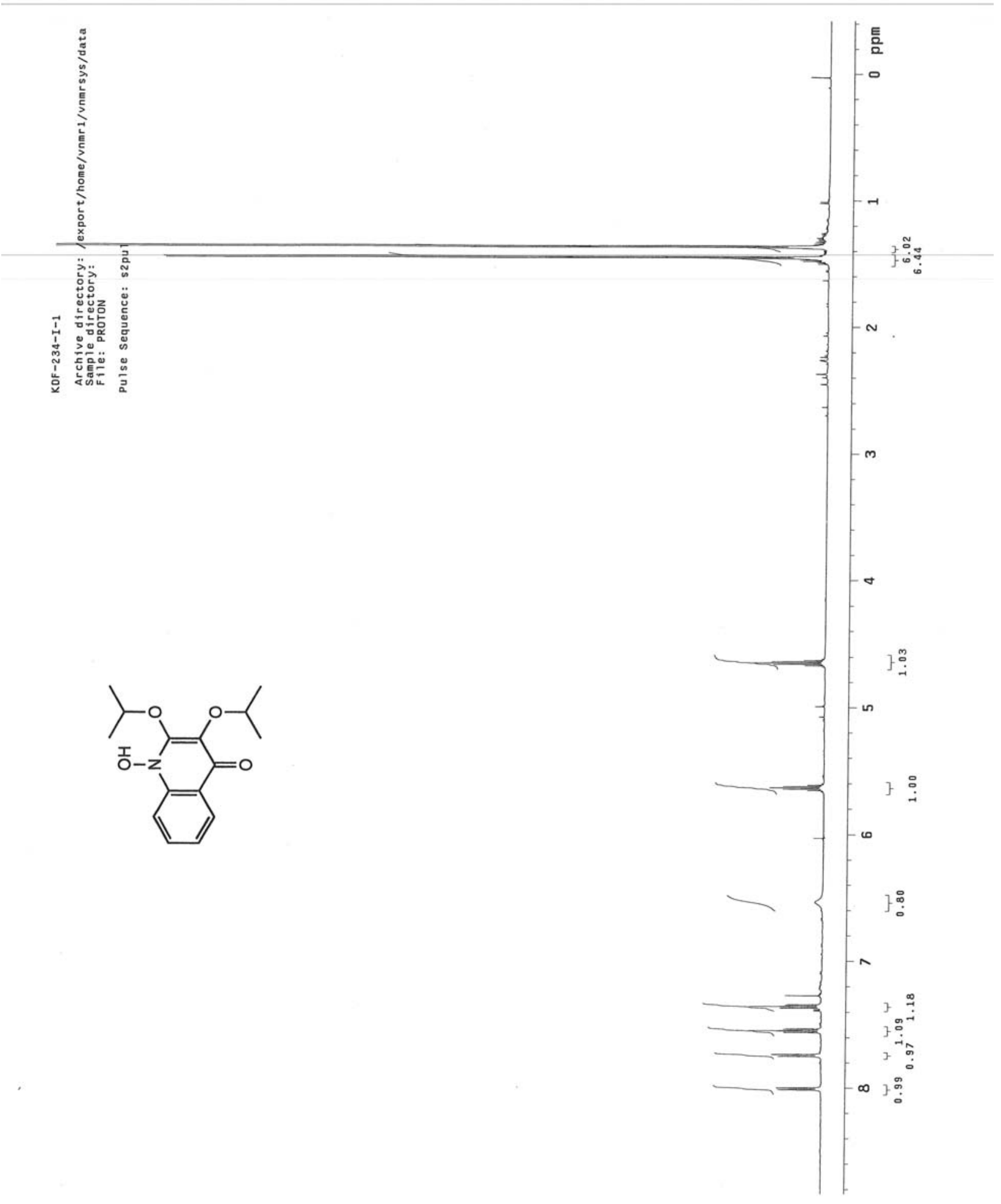

${ }^{1}$ H NMR ,3-diisopropyl-1-hydroxy-4(1H)-quinolinone (40) 


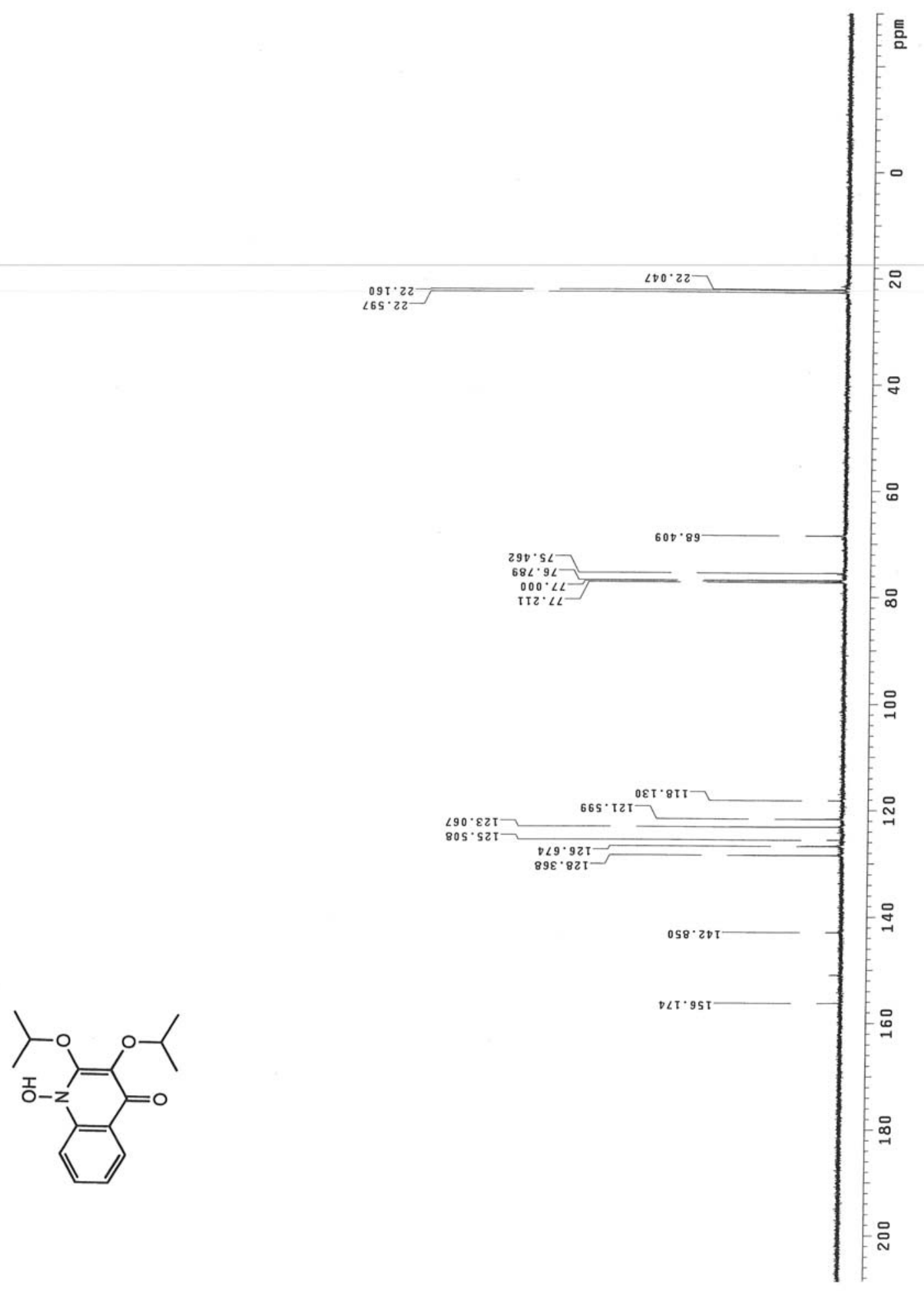

${ }^{13}$ C NMR ,3-diisopropyl-1-hydroxy-4(1H)-quinolinone (40) 


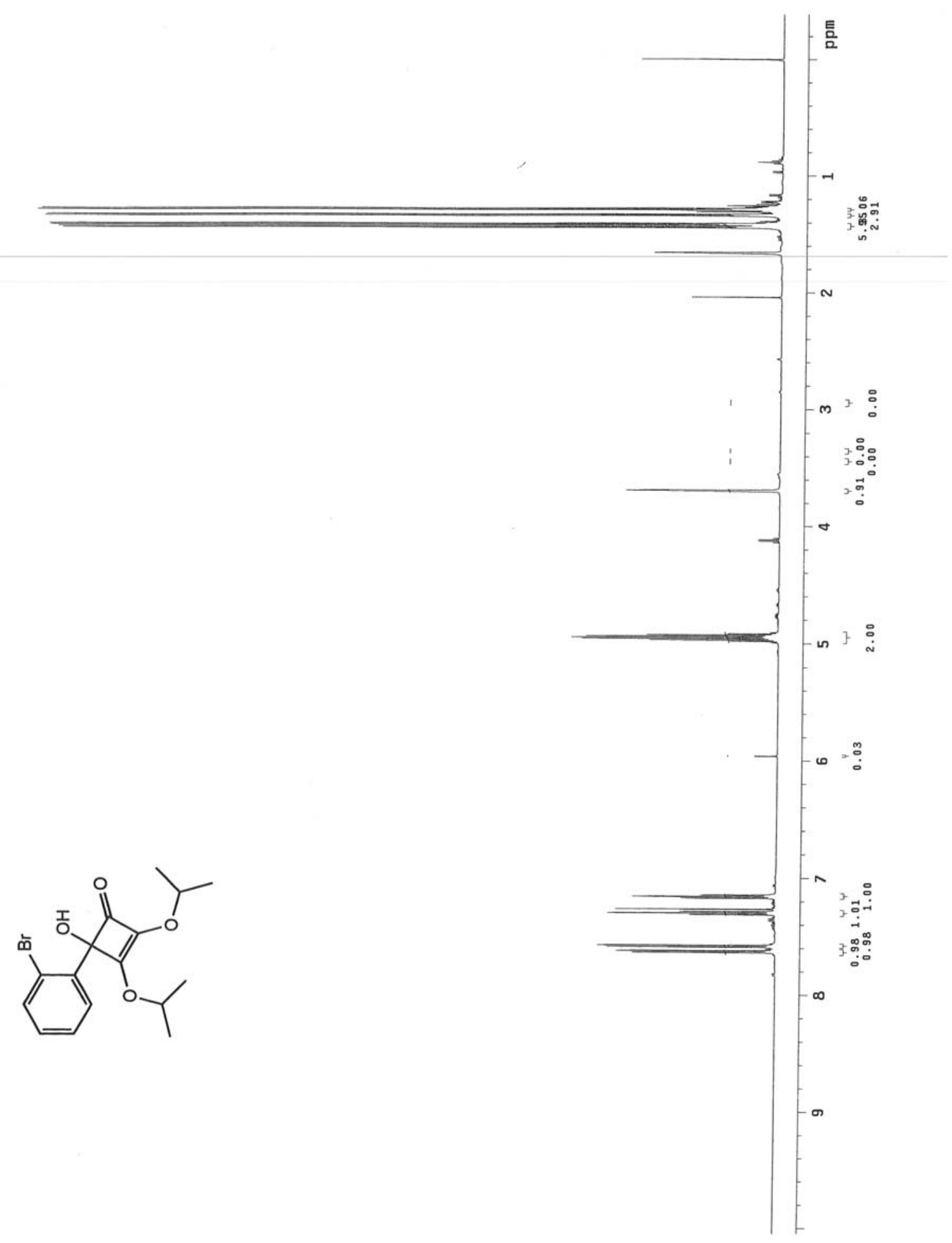

${ }^{1}$ H NMR 4-(2-bromophenyl)-4-hydroxy-2,3-diisopropoxycyclobut-2-enone (49) 


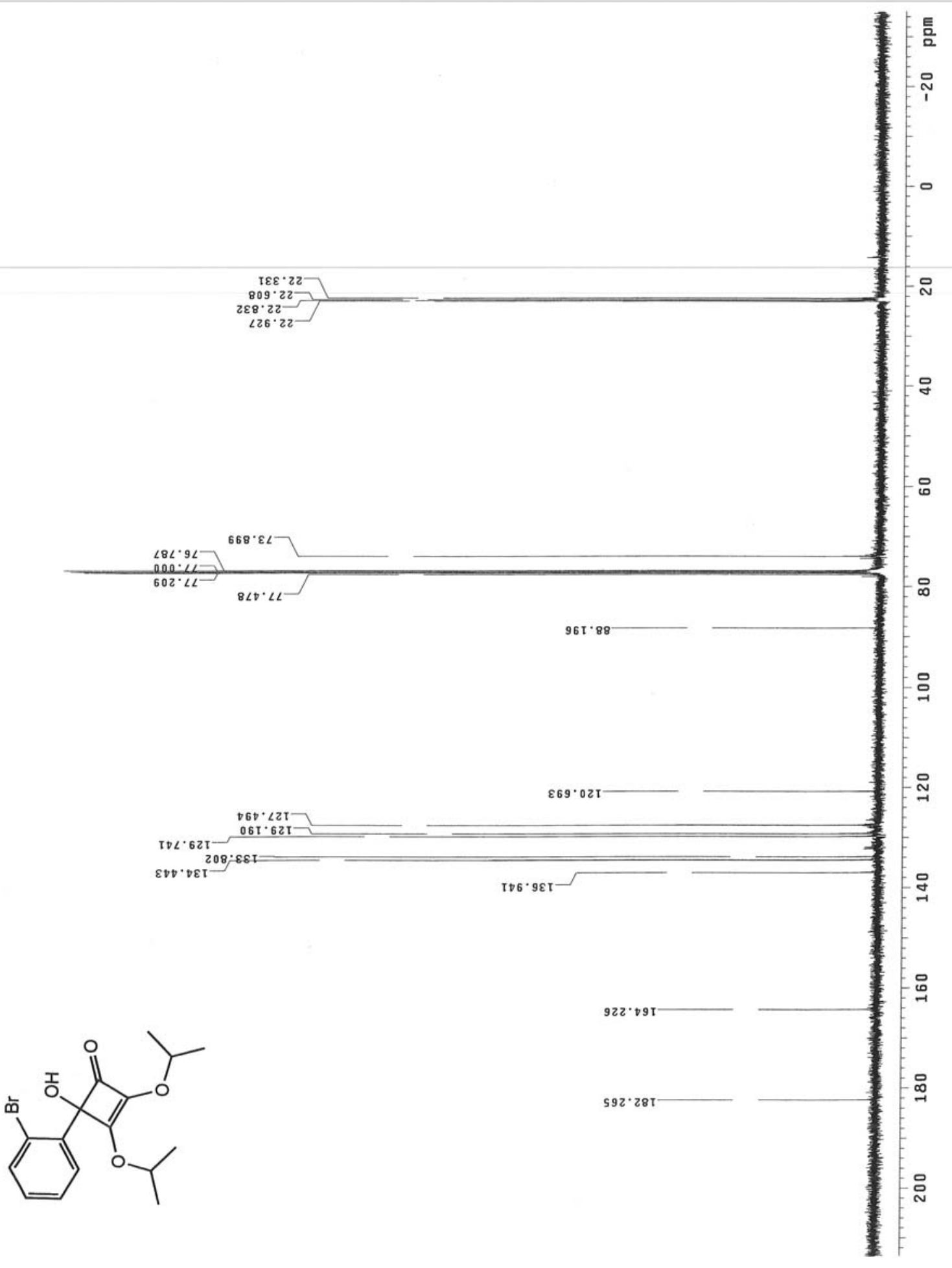

${ }^{13}$ C NMR 4-(2-bromophenyl)-4-hydroxy-2,3-diisopropoxycyclobut-2-enone (49) 


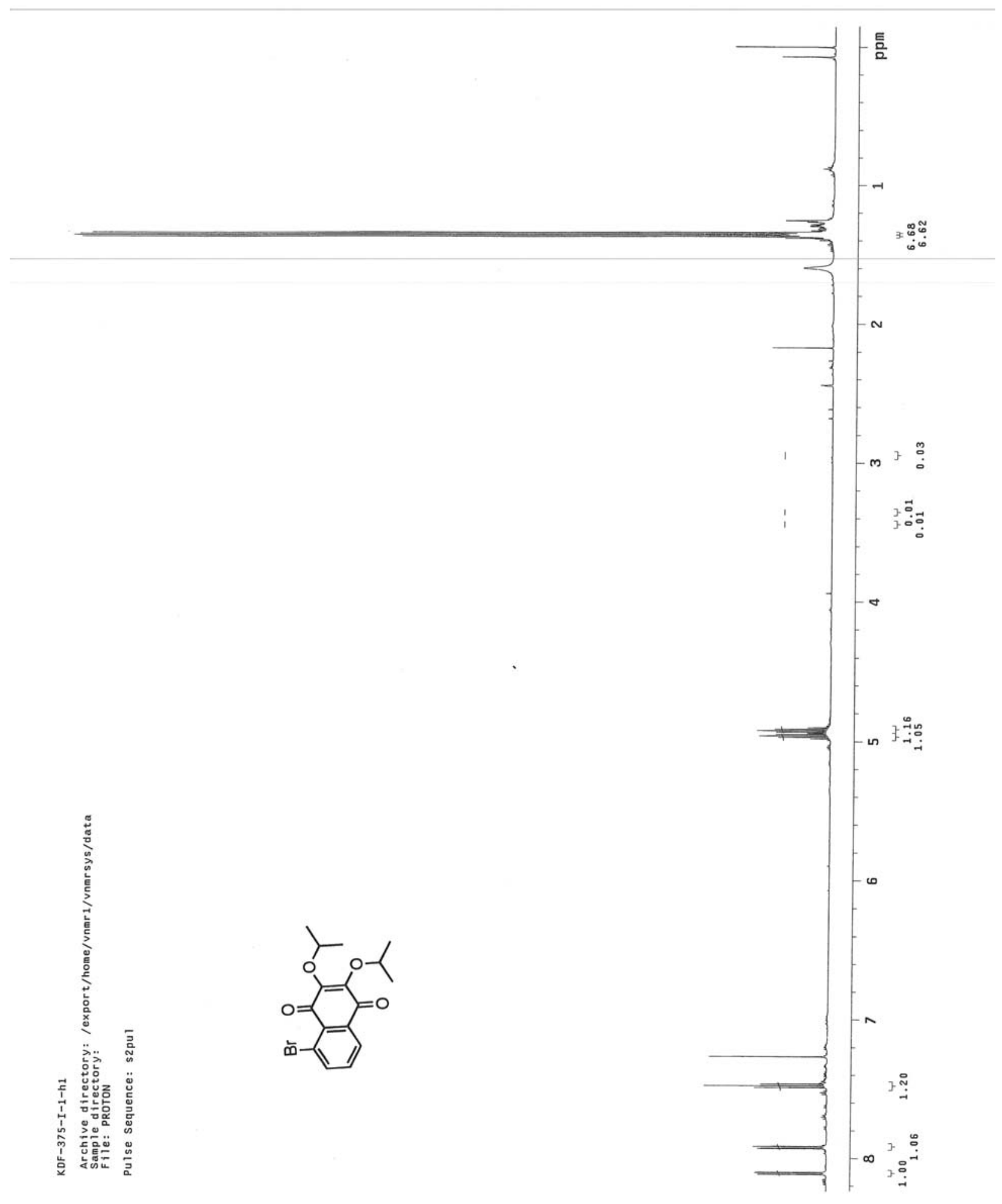

${ }^{1}$ H NMR 5-bromo-2,3-diisopropoxynaphthalene-1,4-dione (50) 


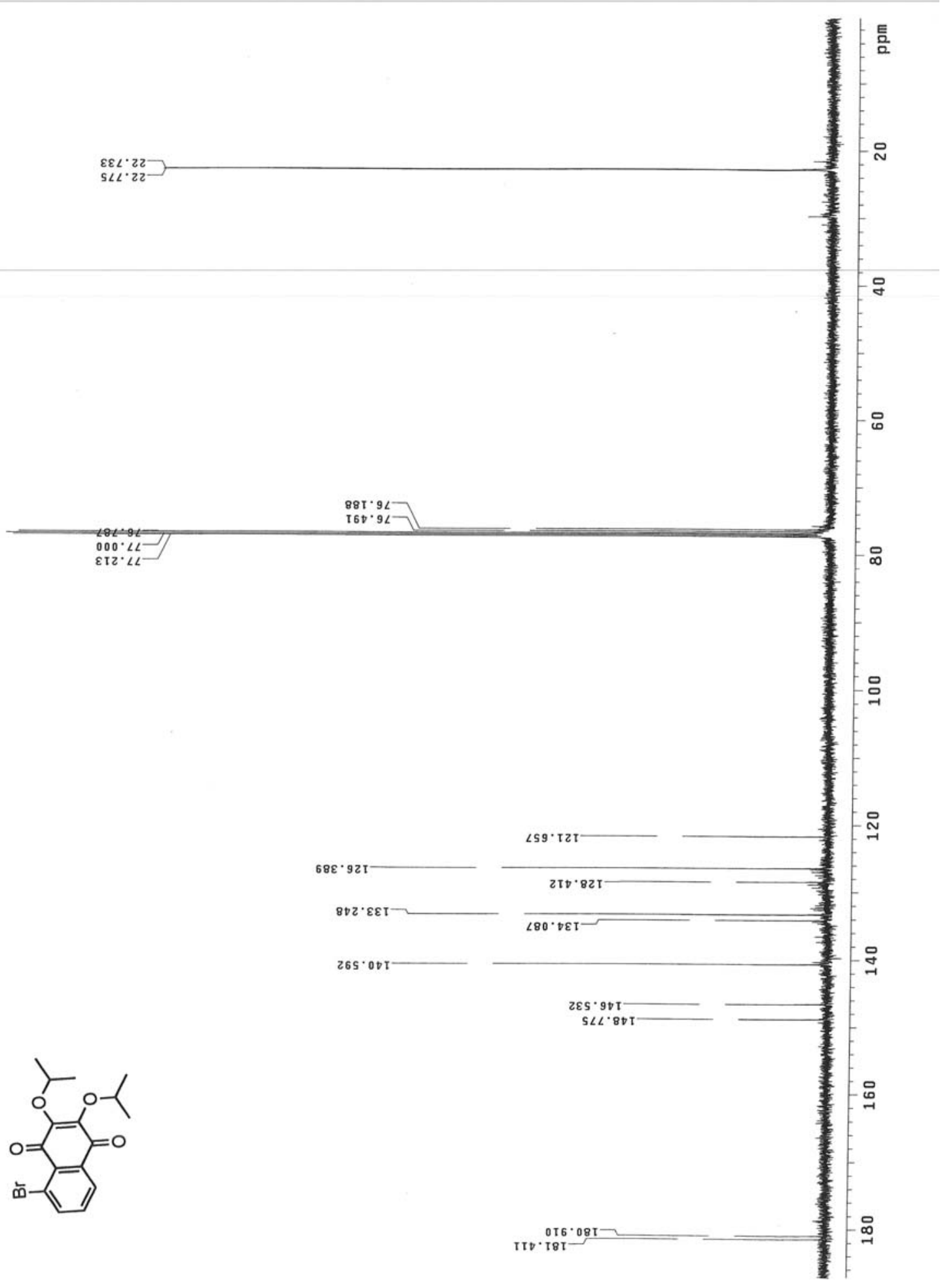

${ }^{13} \mathrm{C}$ NMR 5-bromo-2,3-diisopropoxynaphthalene-1,4-dione (50) 


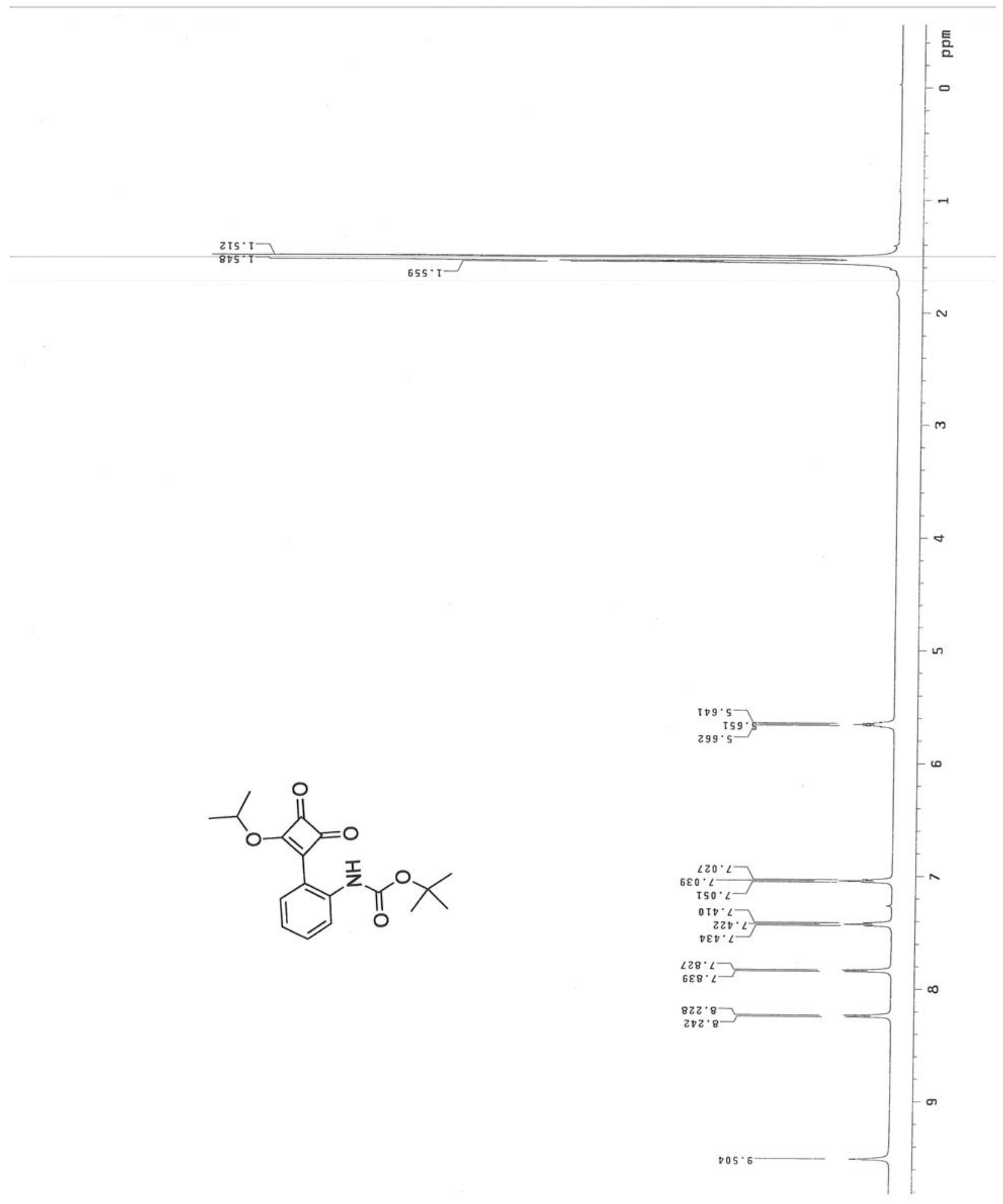

${ }^{1}$ H NMR tert-Butyl 2-(2-isopropoxy-3,4-dioxocyclobut-1-enyl)phenylcarbamate (61) 


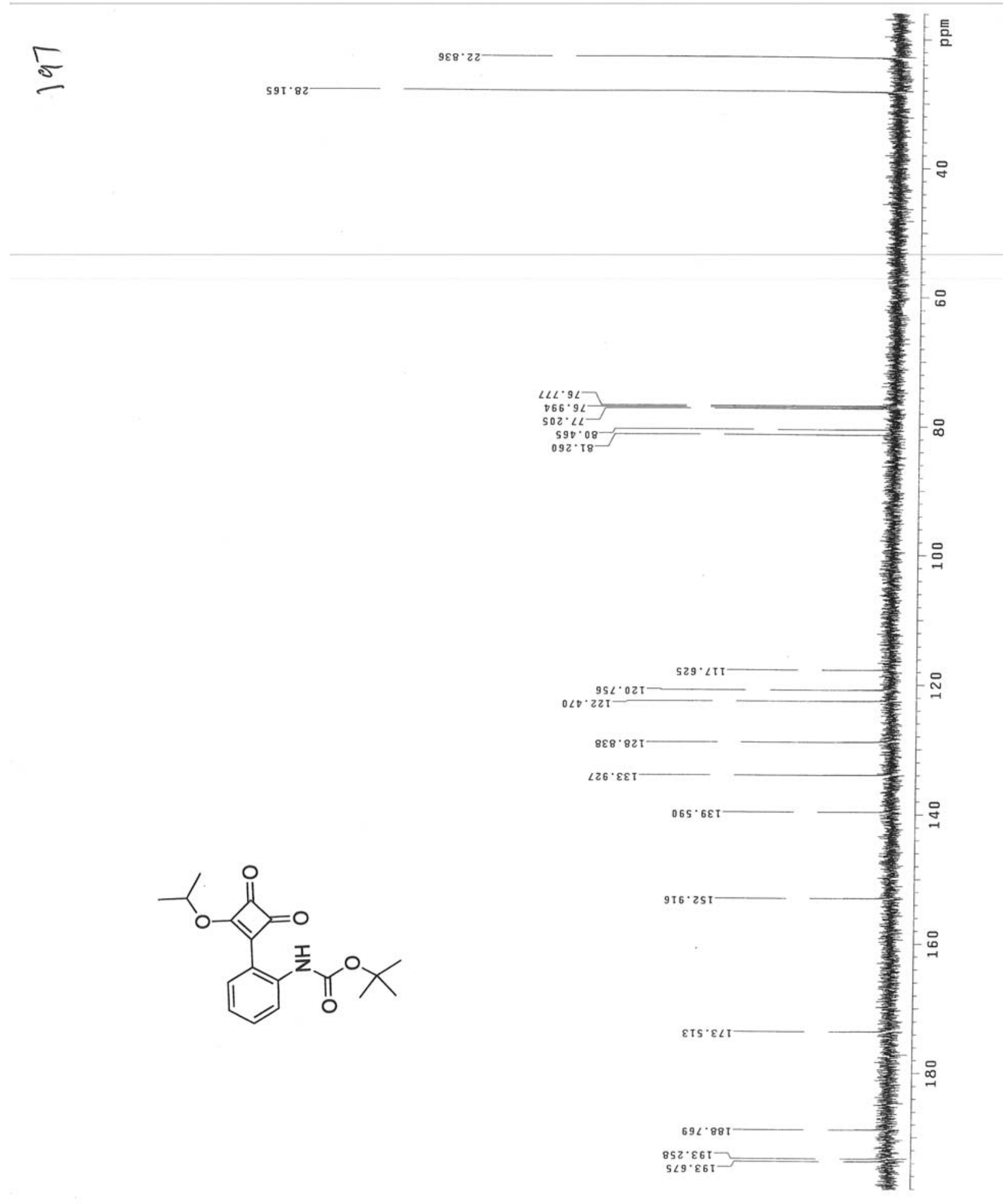

${ }^{13}$ C NMR tert-Butyl 2-(2-isopropoxy-3,4-dioxocyclobut-1-enyl)phenylcarbamate (61) 


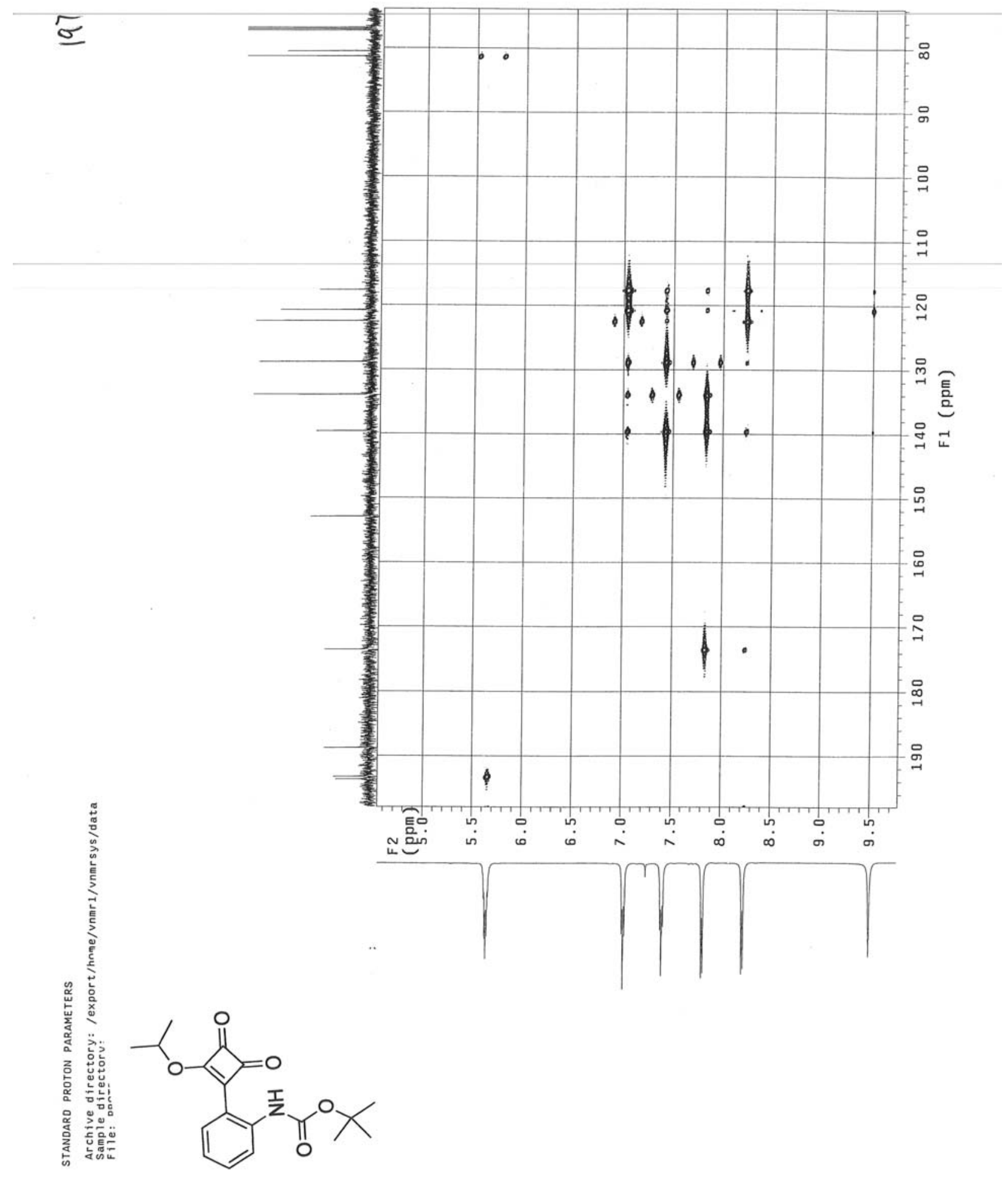

HETCOR tert-Butyl 2-(2-isopropoxy-3,4-dioxocyclobut-1-enyl)phenylcarbamate (61) 


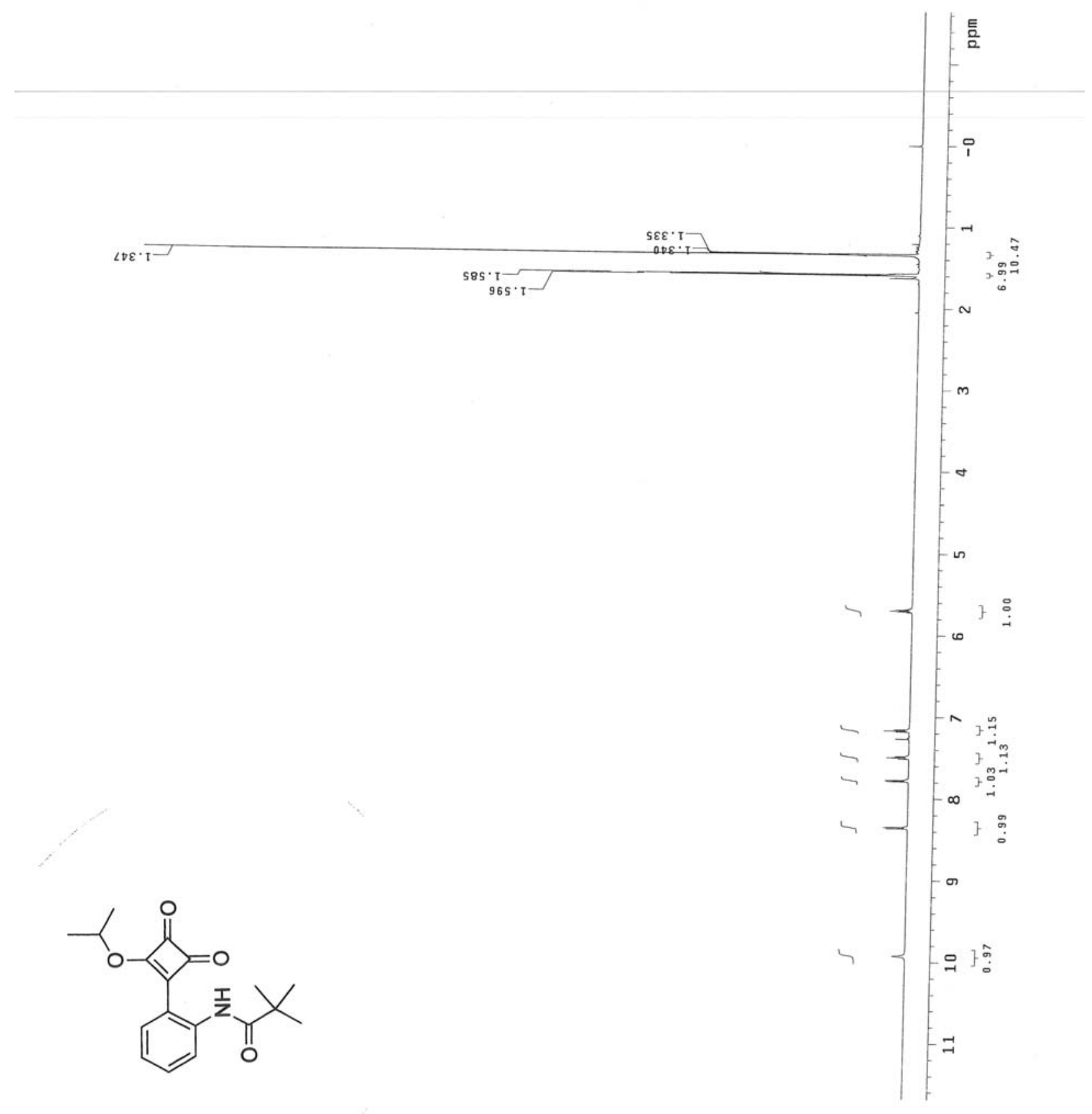

${ }^{1}$ H NMR N-(2-(2-isopropoxy-3,4-dioxocyclobut-1-enyl)phenyl)pivalamide (62) 


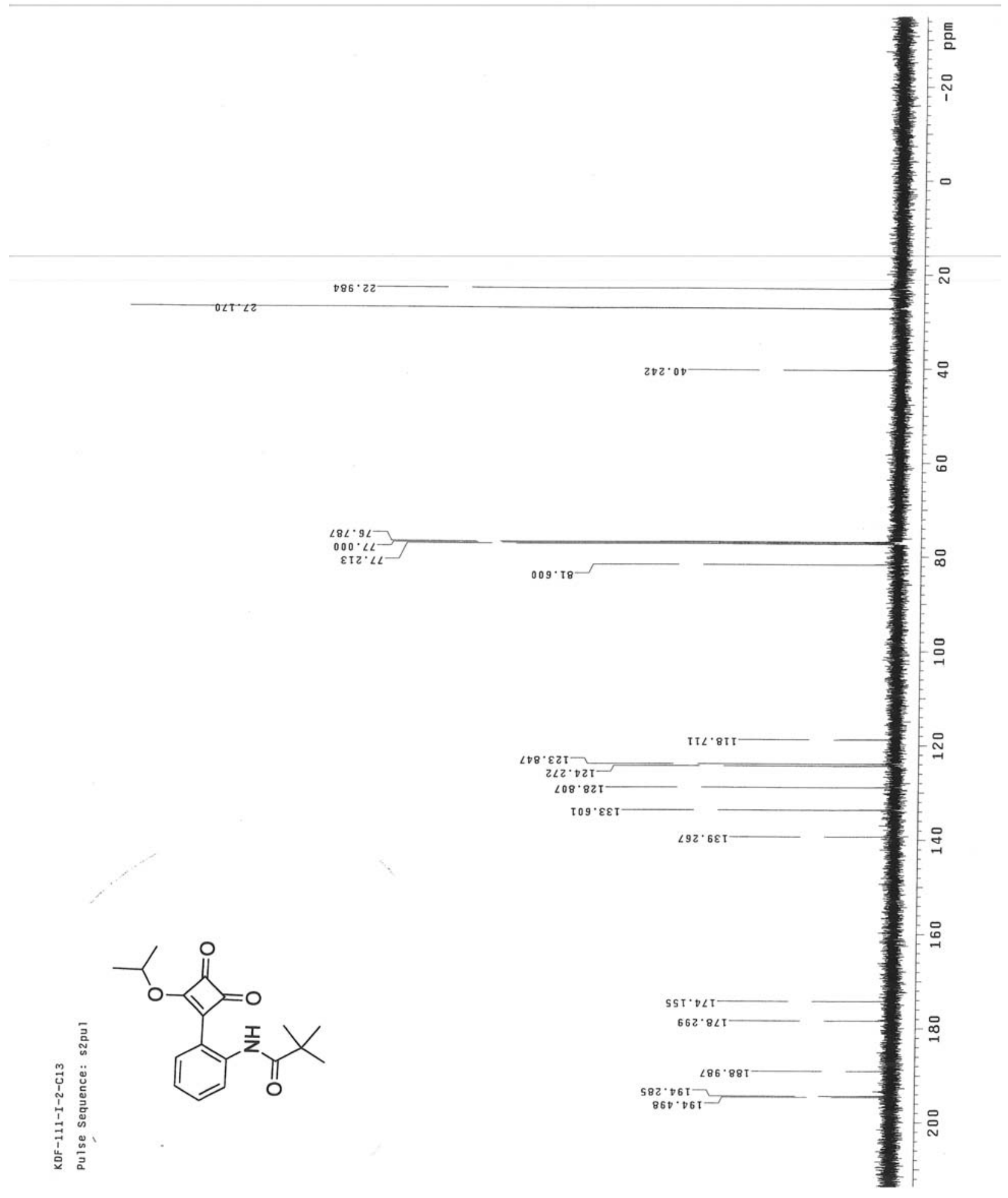

${ }^{13}$ C NMR N-(2-(2-isopropoxy-3,4-dioxocyclobut-1-enyl)phenyl)pivalamide (62)

134 


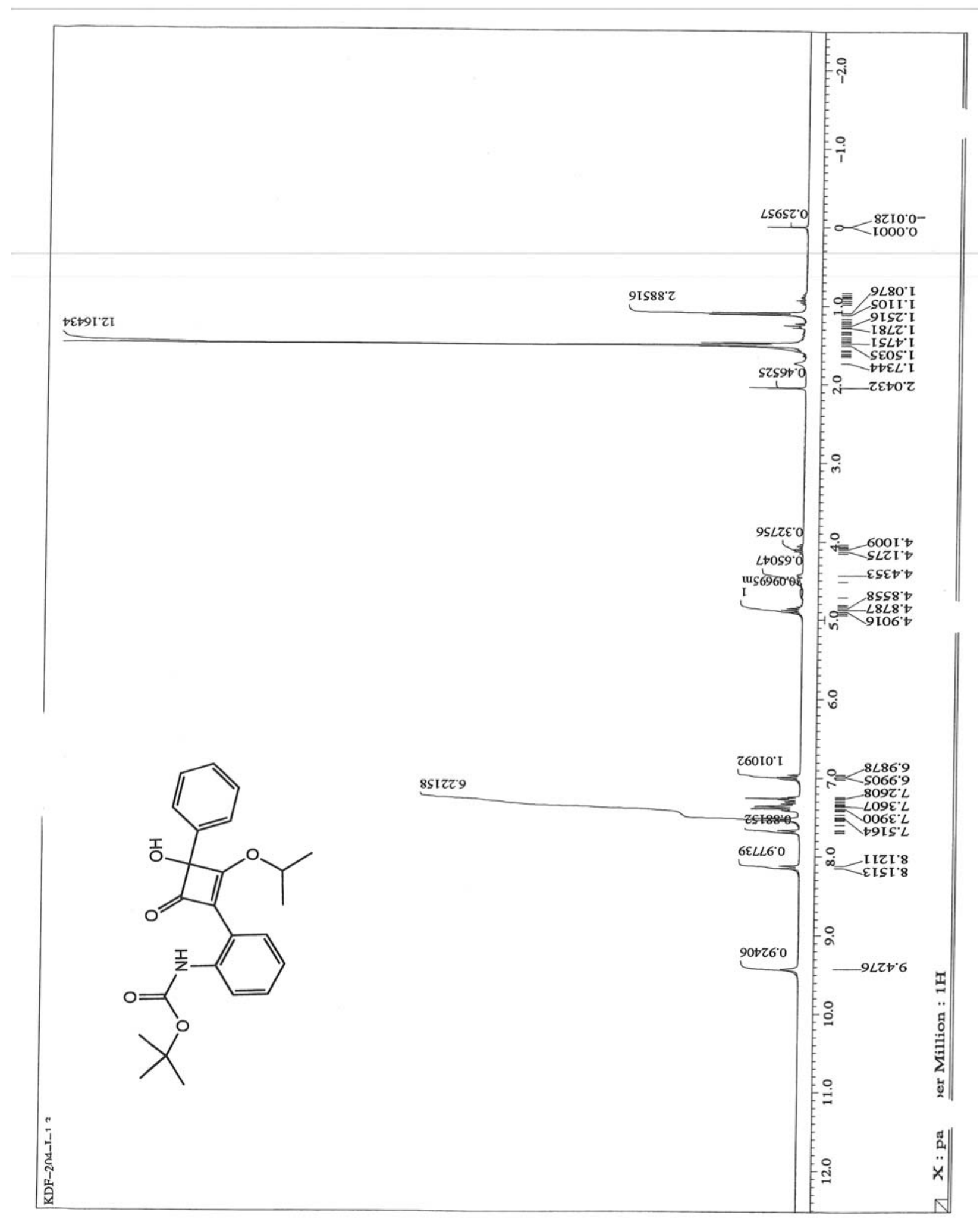

${ }^{1}$ H NMR tert-Butyl 2-(3-hydroxy-2-isopropoxy-4-oxo-3-phenylcyclobut-1enyl)phenylcarbamate (63) 


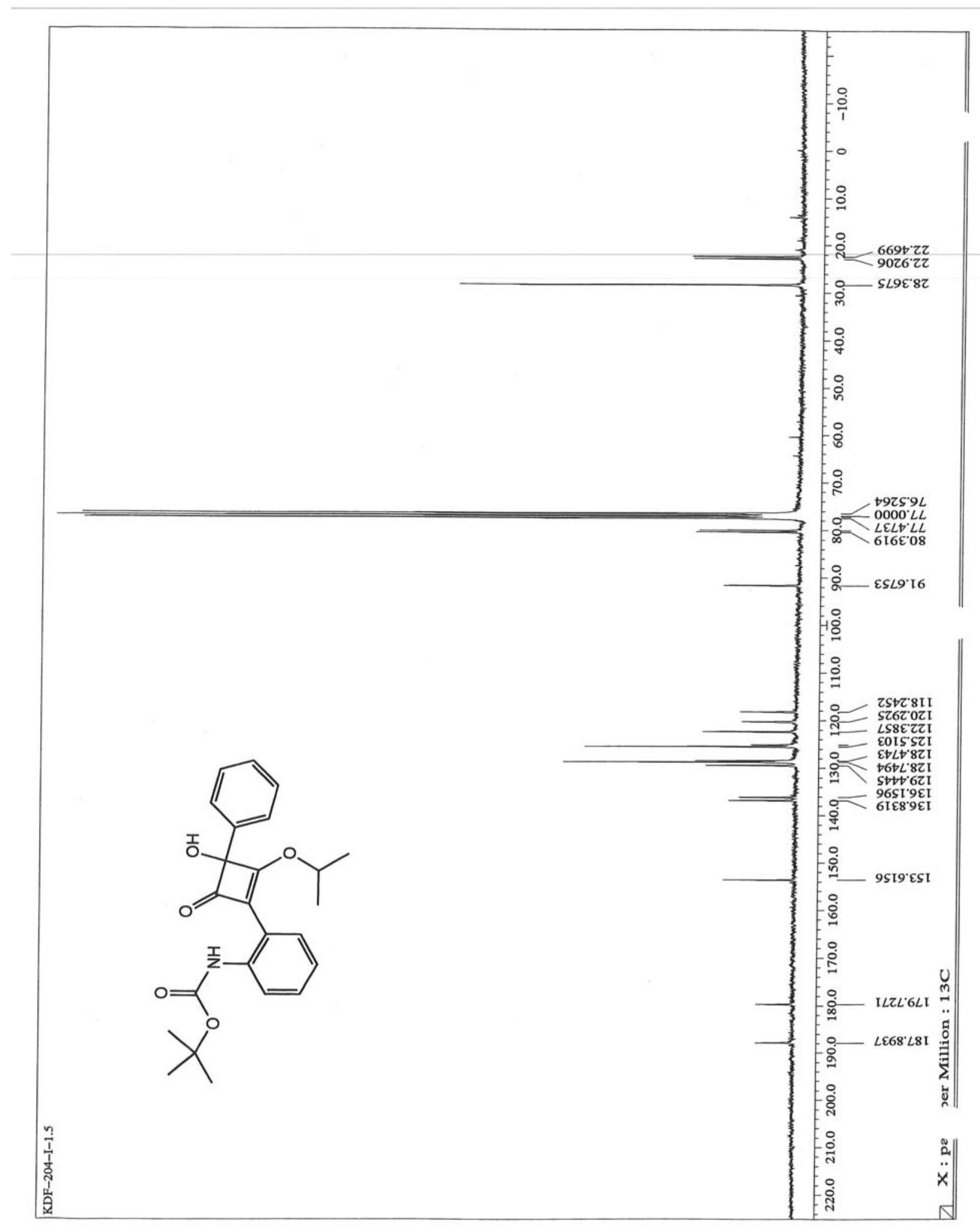

${ }^{13}$ C NMR tert-Butyl 2-(3-hydroxy-2-isopropoxy-4-oxo-3-phenylcyclobut-1enyl)phenylcarbamate (63) 


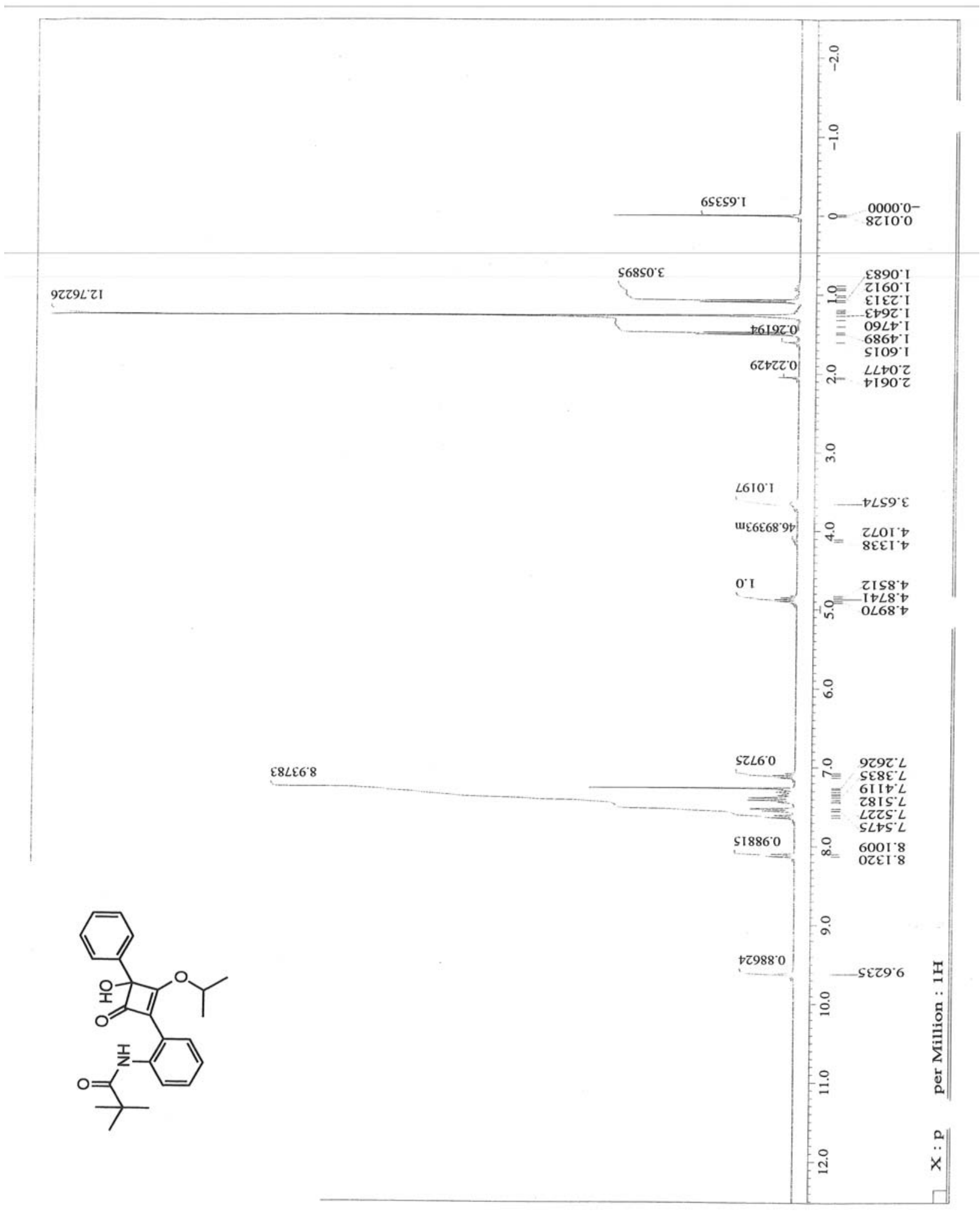

${ }^{1}{ }_{H}$ NMR N-(2-(3-hydroxy-2-isopropoxy-4-oxo-3-phenylcyclobut-1-enyl)phenyl)pivalamide (64) 


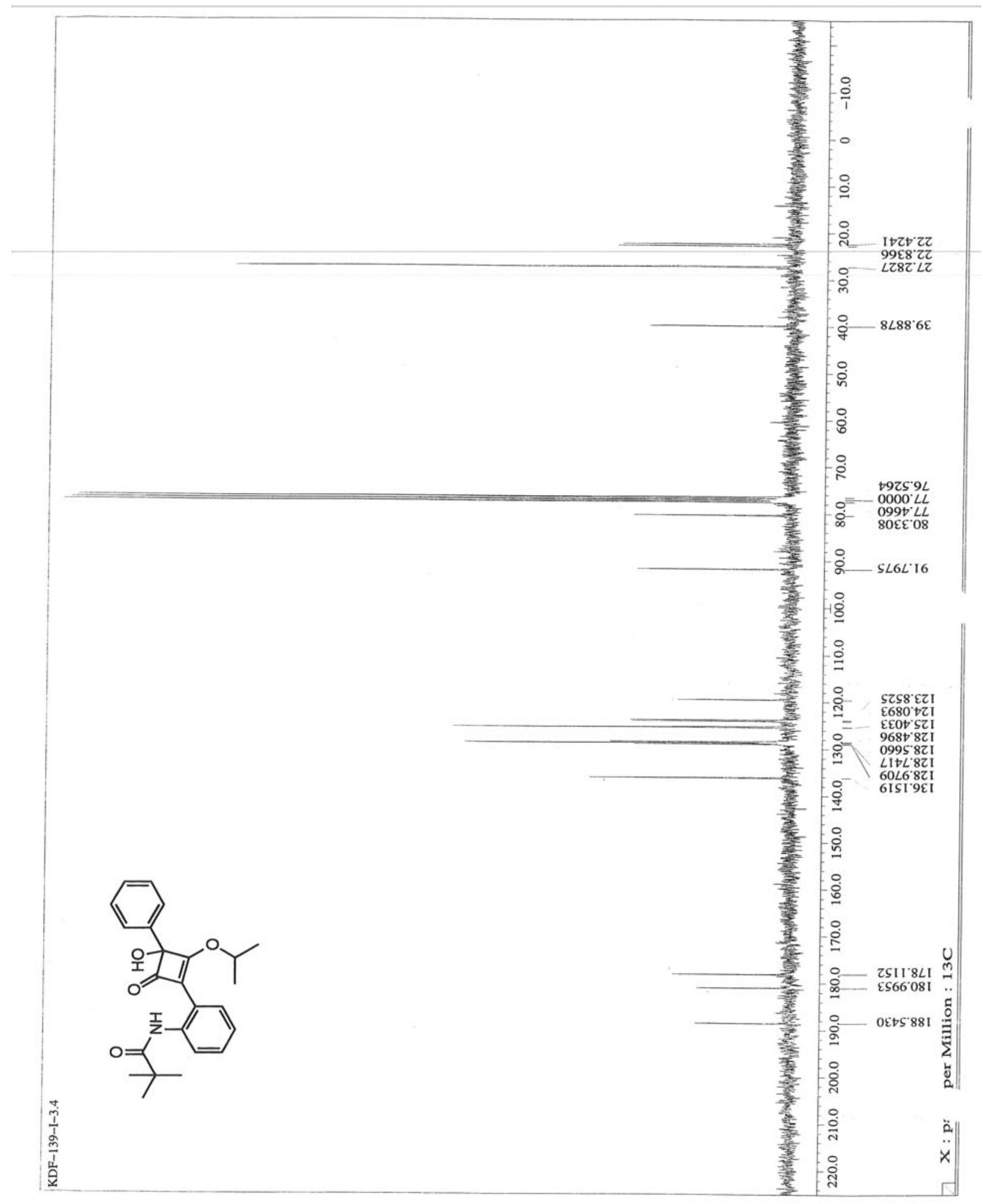

${ }^{13}$ C NMR N-(2-(3-hydroxy-2-isopropoxy-4-oxo-3-phenylcyclobut-1-enyl)phenyl)pivalamide (64) 


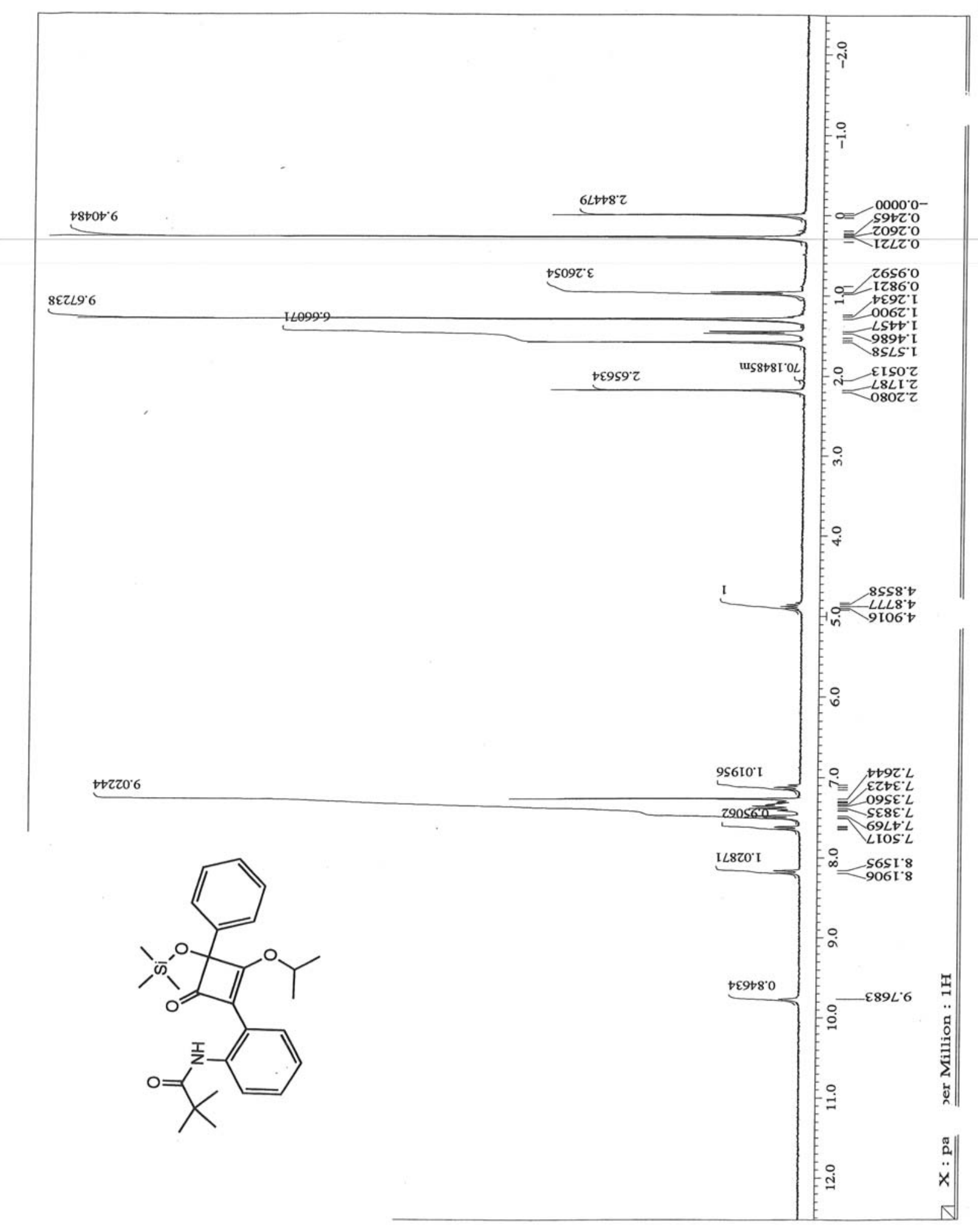

${ }^{1} \mathrm{H}$ NMR N-(2-(3-Trimethylsilylhydroxy-2-isopropoxy-4-oxo-3-phenylcyclobut-1enyl)phenyl)pivalamide (65) 


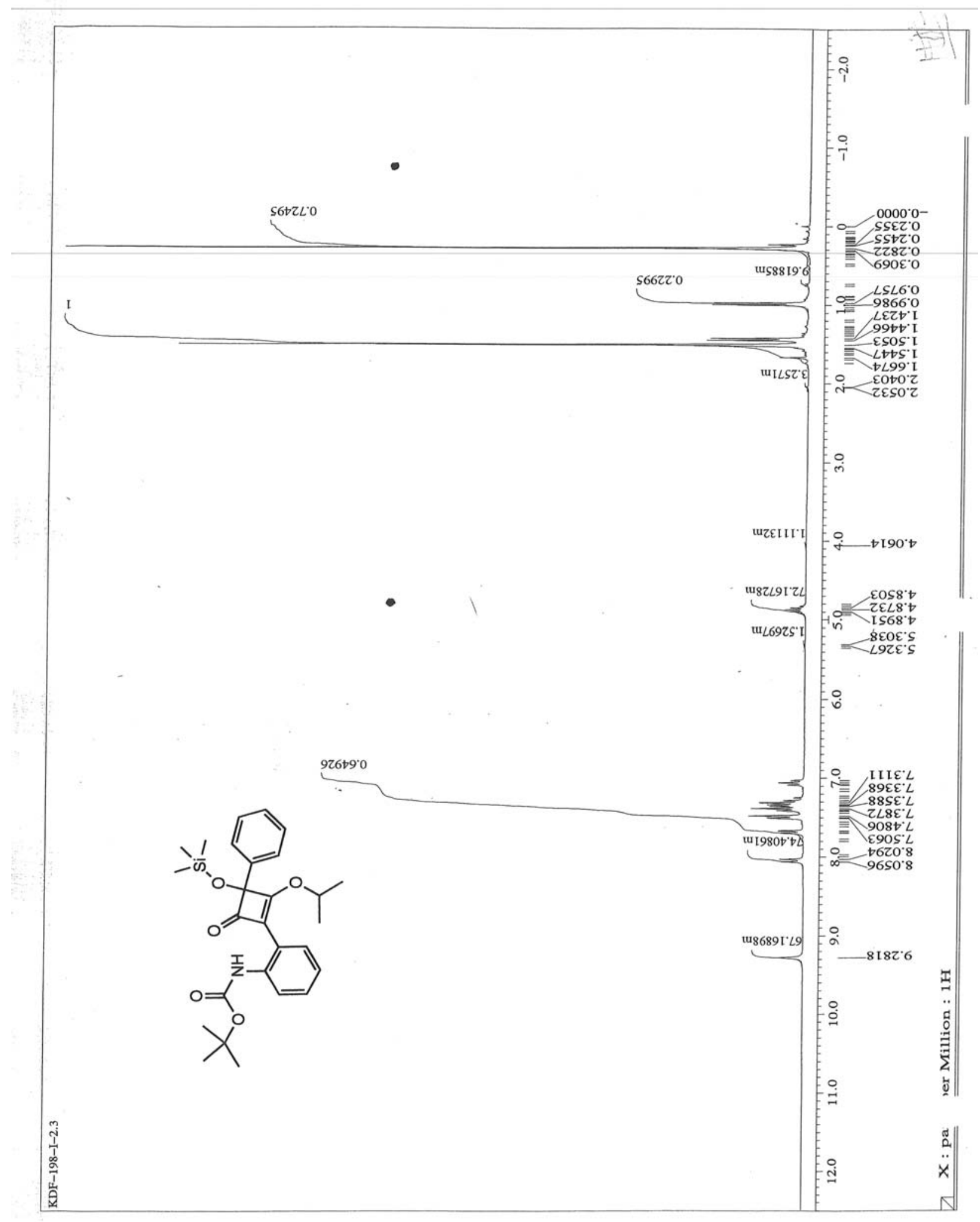

${ }^{1}$ H NMR tert-Butyl 2-(3-Trimethylsilylhydroxy-2-isopropoxy-4-oxo-3-phenylcyclobut-1enyl)phenylcarbamate (66) 


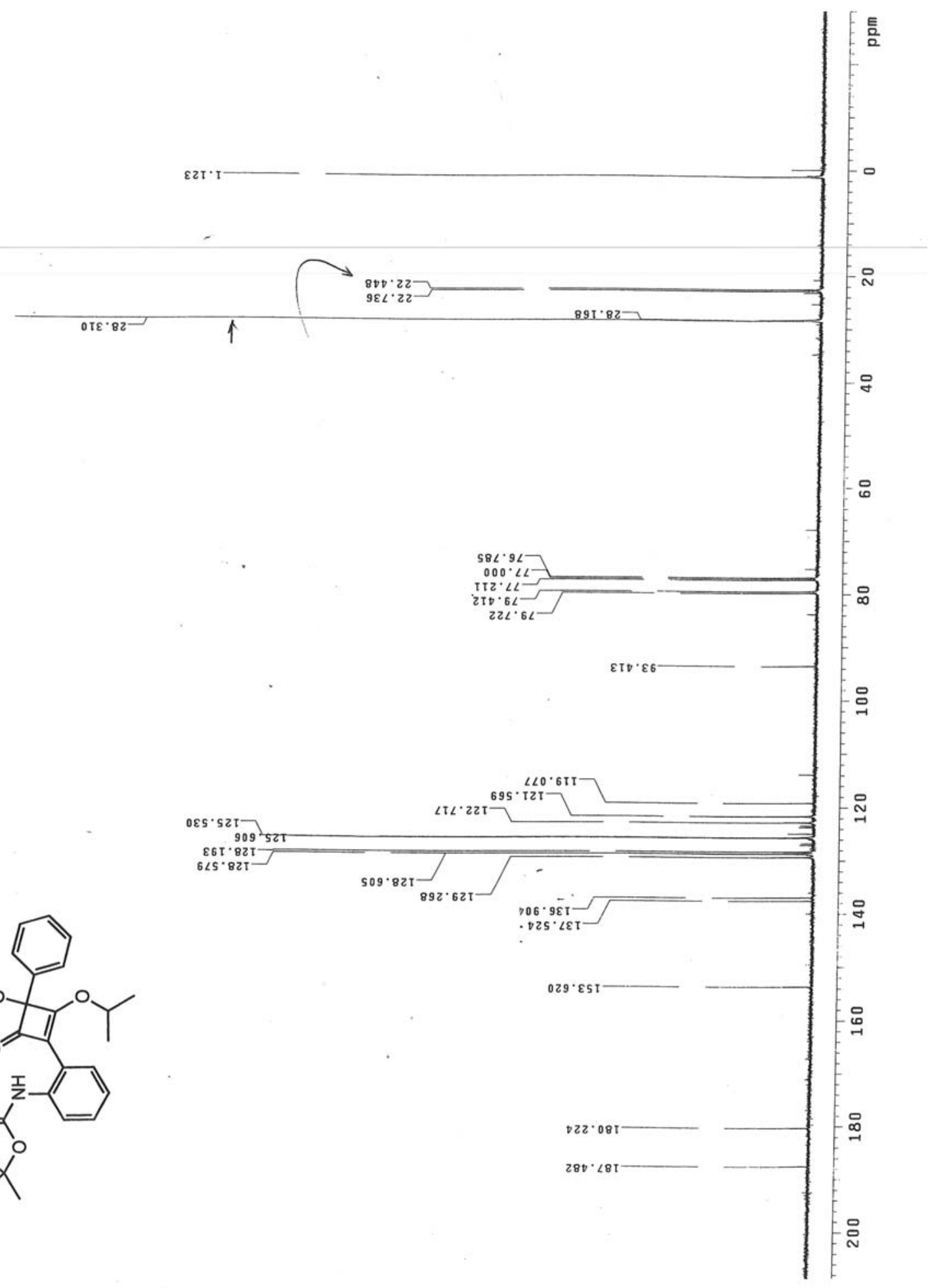

${ }^{13}$ C NMR tert-Butyl 2-(3-Trimethylsilylhydroxy-2-isopropoxy-4-oxo-3-phenylcyclobut-1enyl)phenylcarbamate (66) 


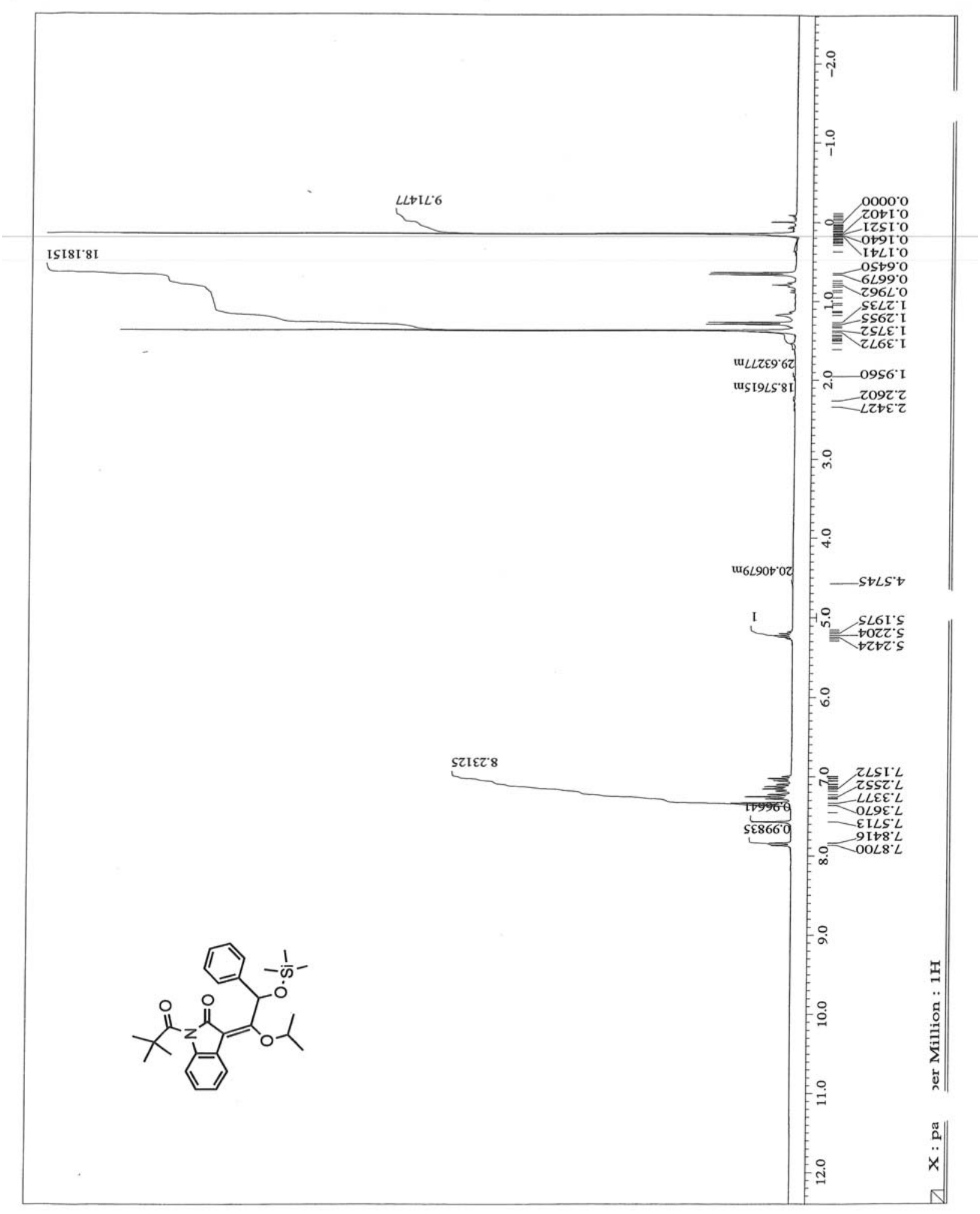

${ }^{1}$ H NMR 3-(2-trimethylsilylhydroxy-1-isopropoxy-2-phenylethylidene)-1-(pivaloyl)indolin-2one (67) 


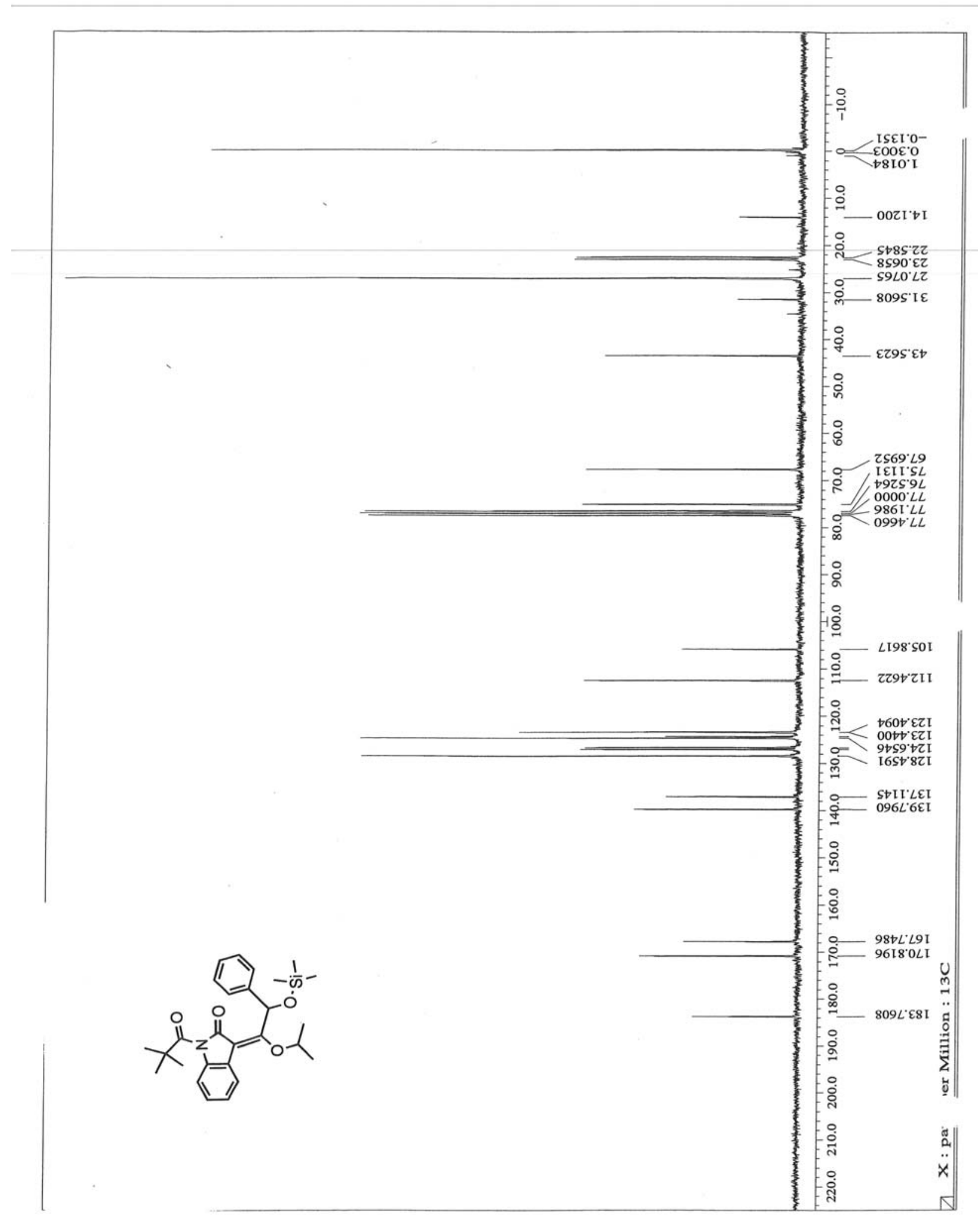

${ }^{13}$ C NMR 3-(2-trimethylsilylhydroxy-1-isopropoxy-2-phenylethylidene)-1-(pivaloyl)indolin-2one (67) 


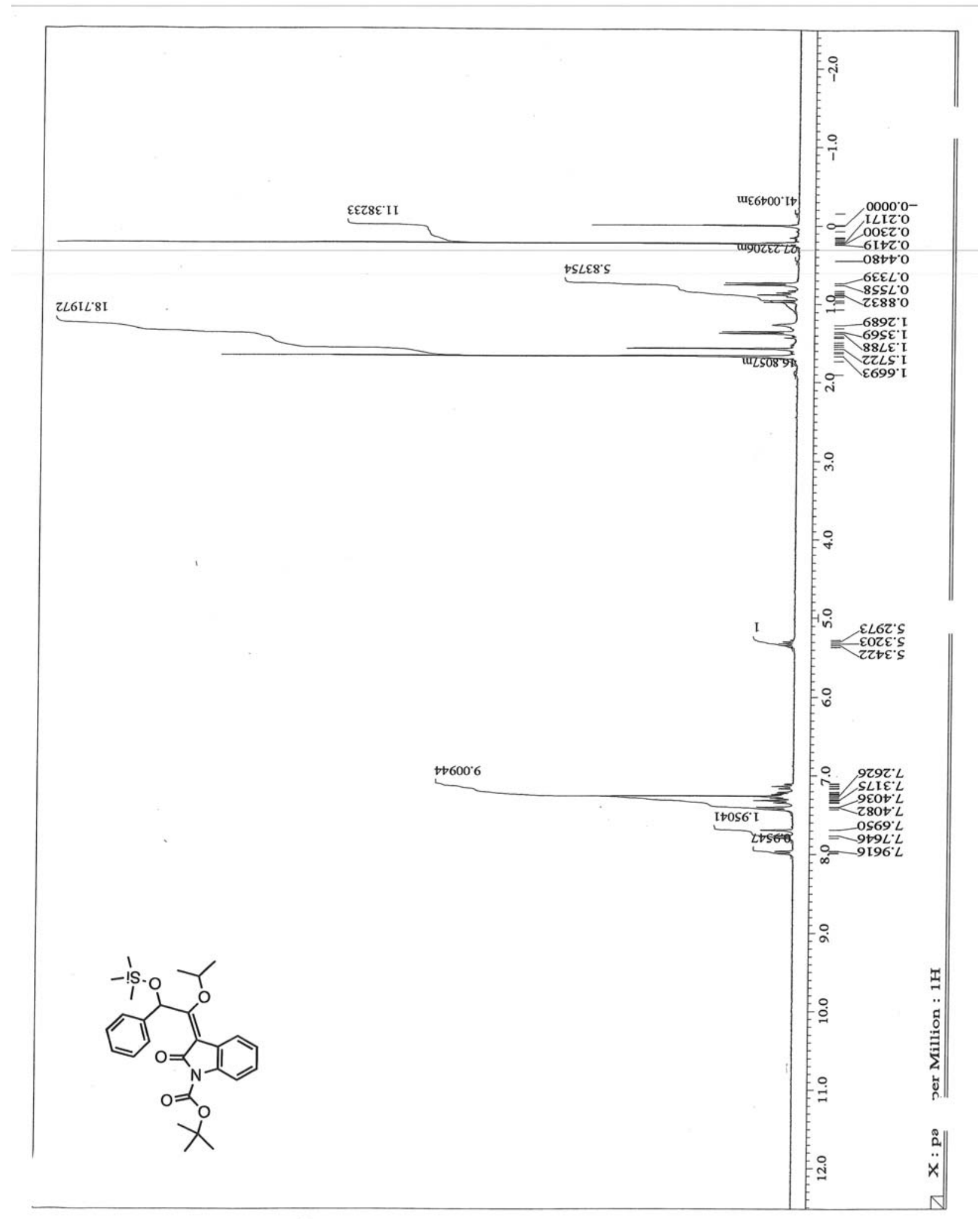

${ }^{1} \mathrm{H}$ NMR tert-Butyl 3-(2-Trimethylsilylhydroxy-1-isopropoxy-2-phenylethylidene)-2oxoindoline-1-carboxylate (68) 


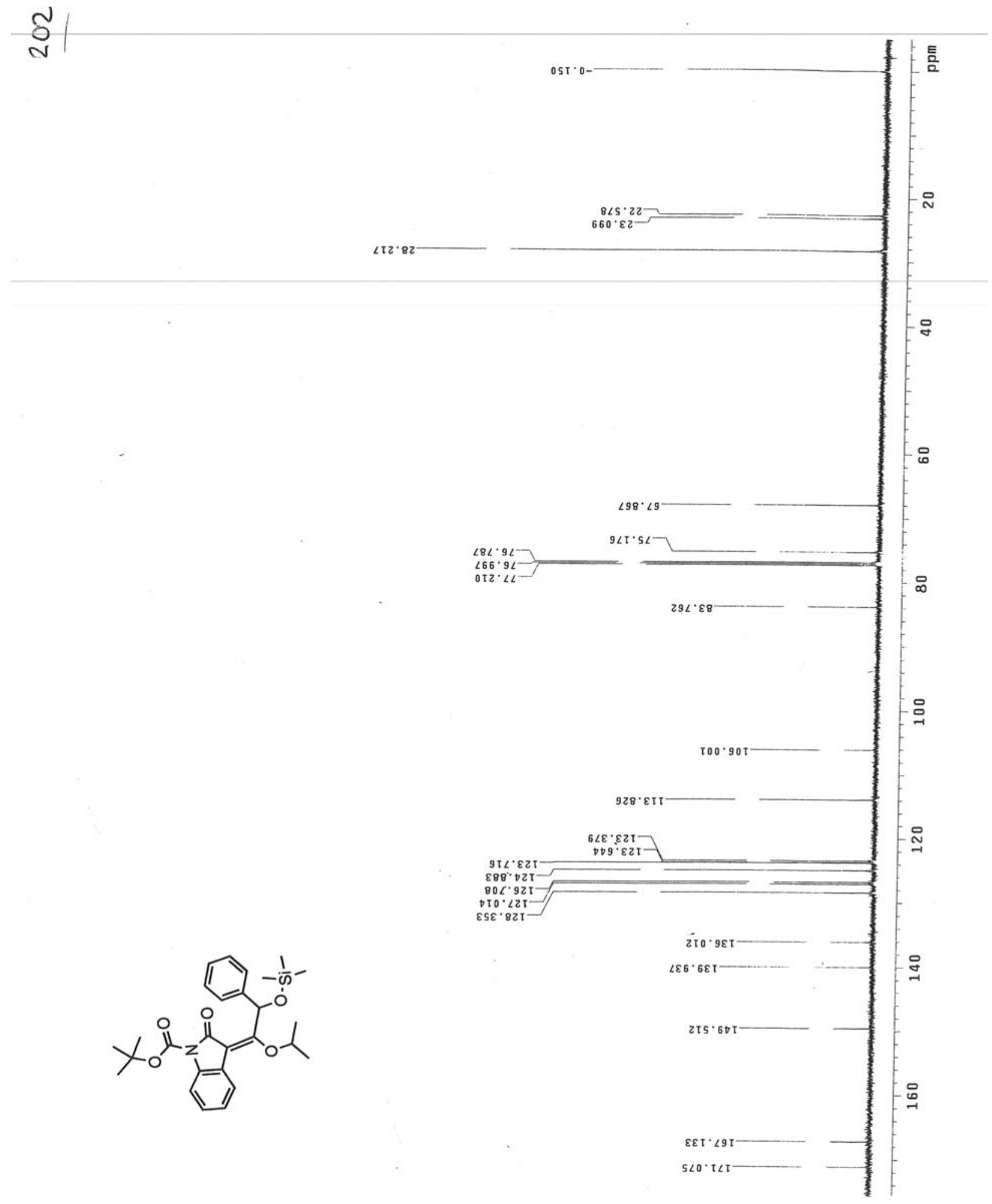

${ }^{13}$ C NMR tert-Butyl 3-(2-Trimethylsilylhydroxy-1-isopropoxy-2-phenylethylidene)-2oxoindoline-1-carboxylate (68) 


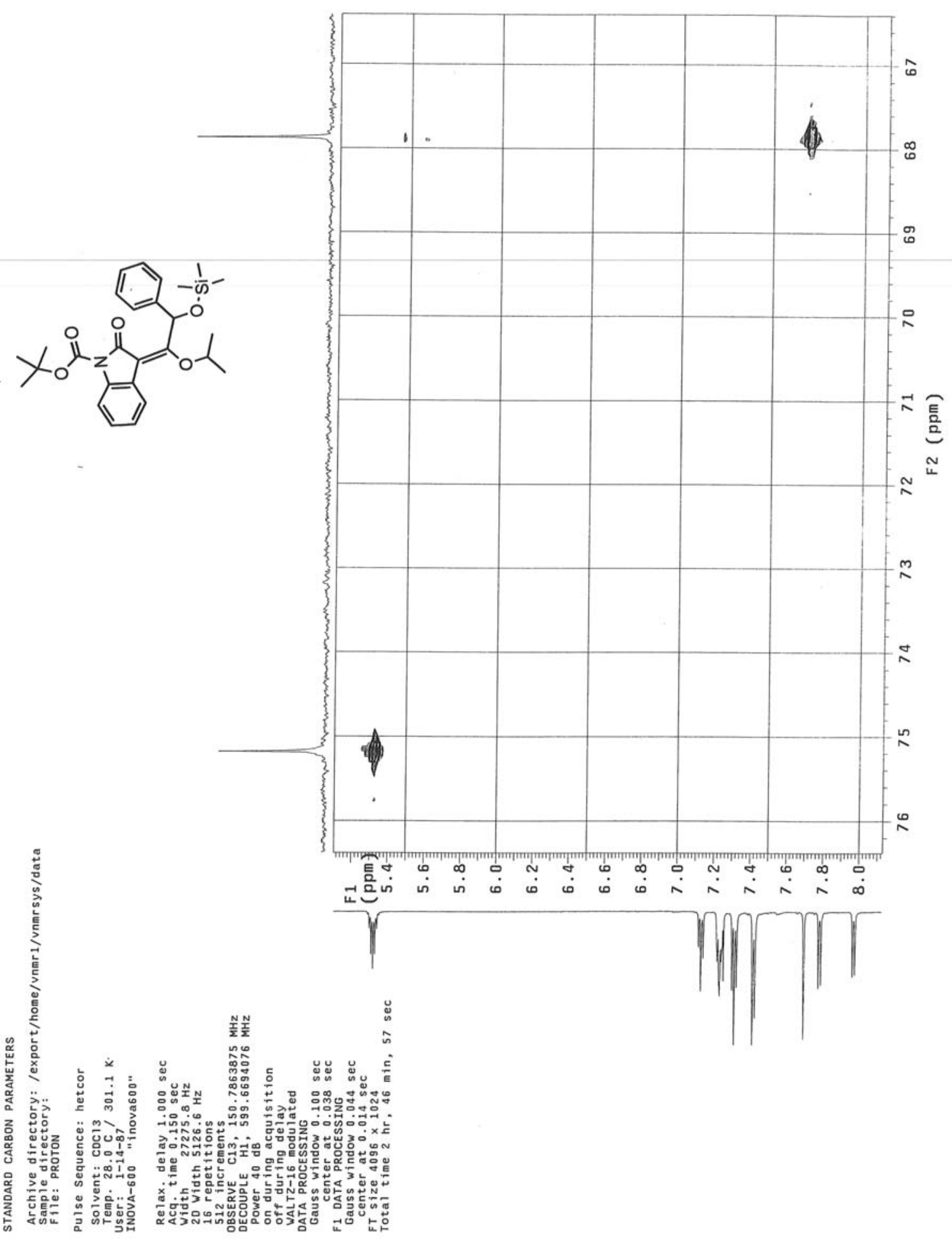

HETCOR tert-Butyl 3-(2-Trimethylsilylhydroxy-1-isopropoxy-2-phenylethylidene)-2oxoindoline-1-carboxylate (68) 


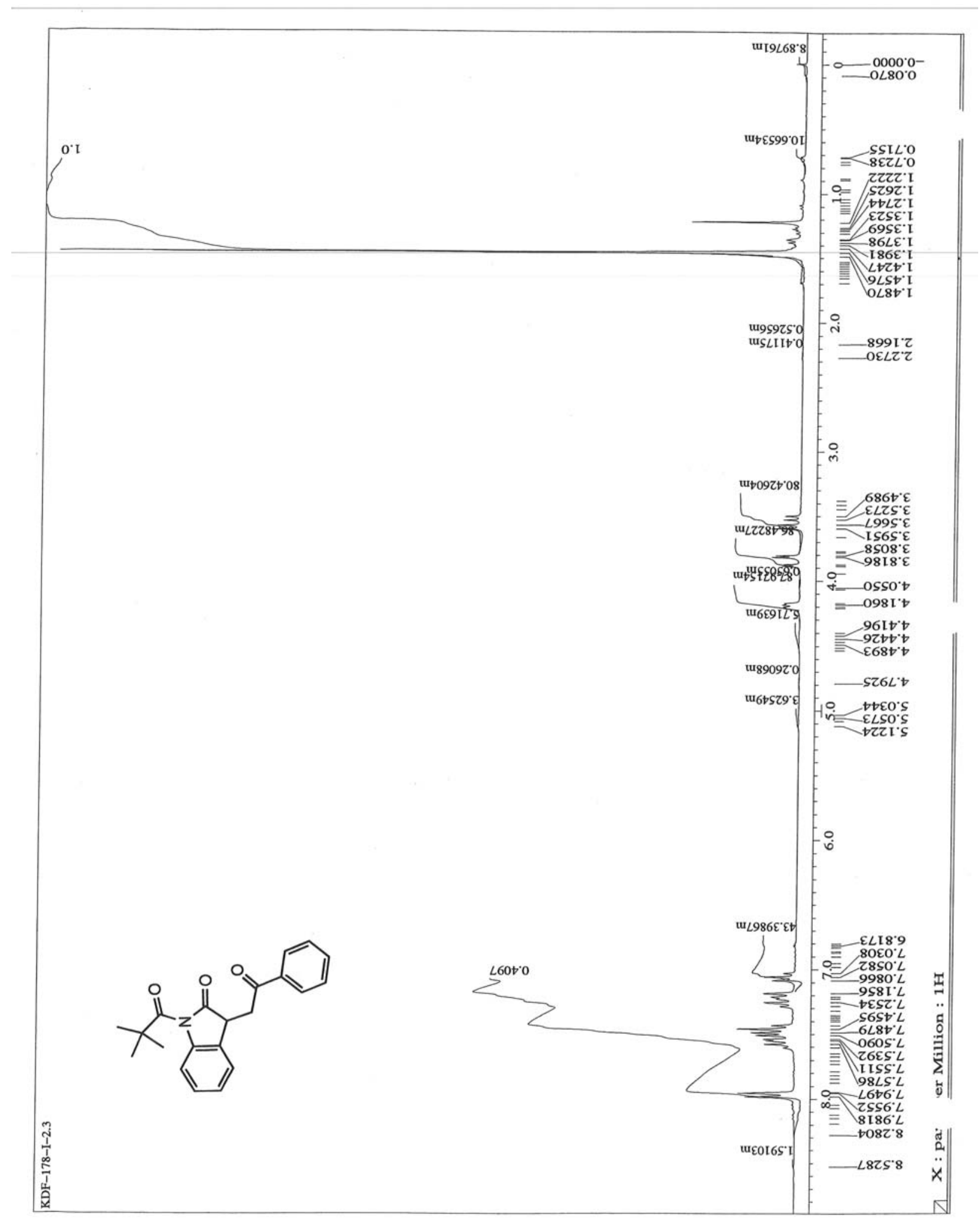

${ }^{1}$ H NMR 3-(2-phenyl-ethan-2-one)-1-(pivaloyl)indolin-2-one (74) 


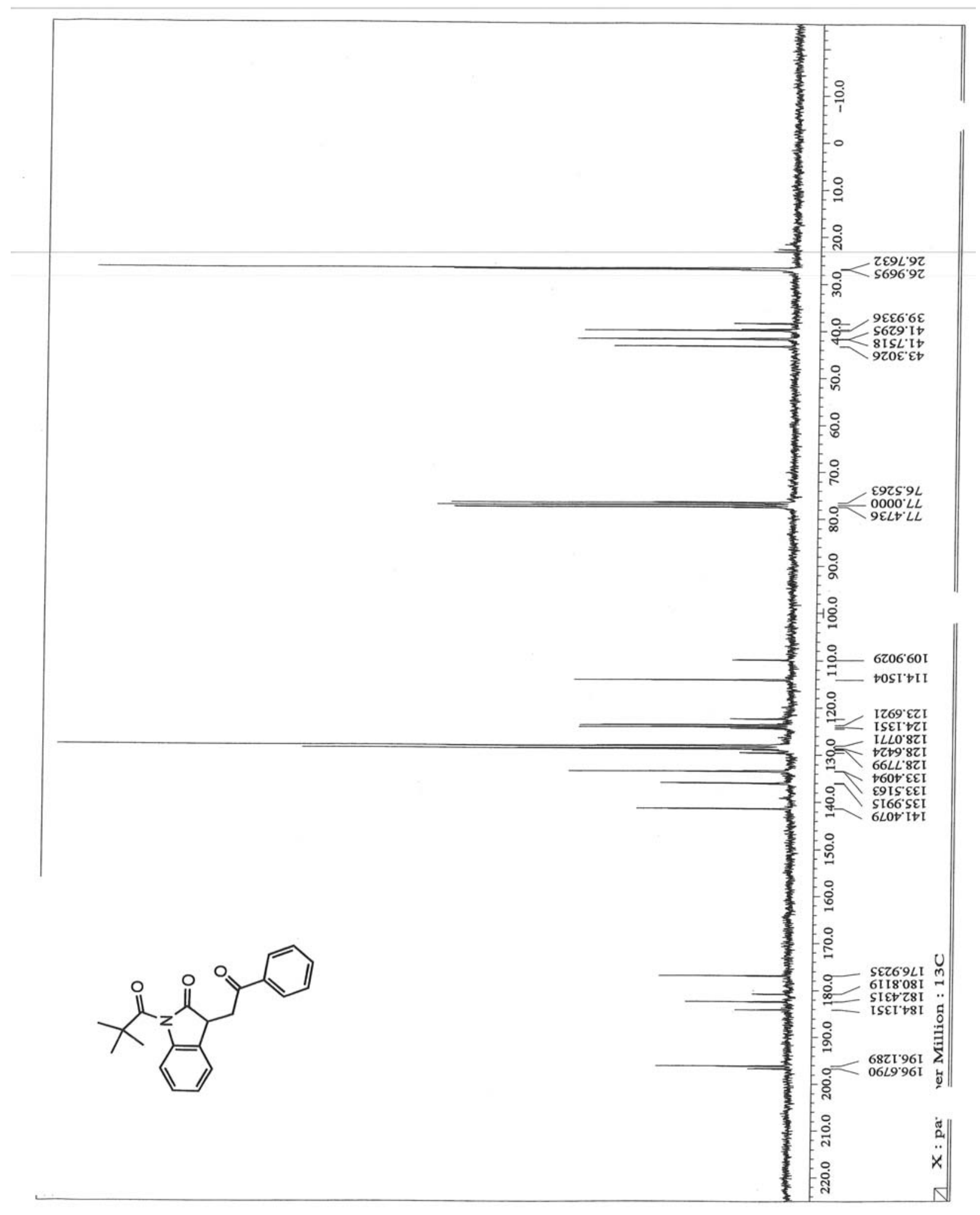

${ }^{13}$ C NMR 3-(2-phenyl-ethan-2-one)-1-(pivaloyl)indolin-2-one (74) 


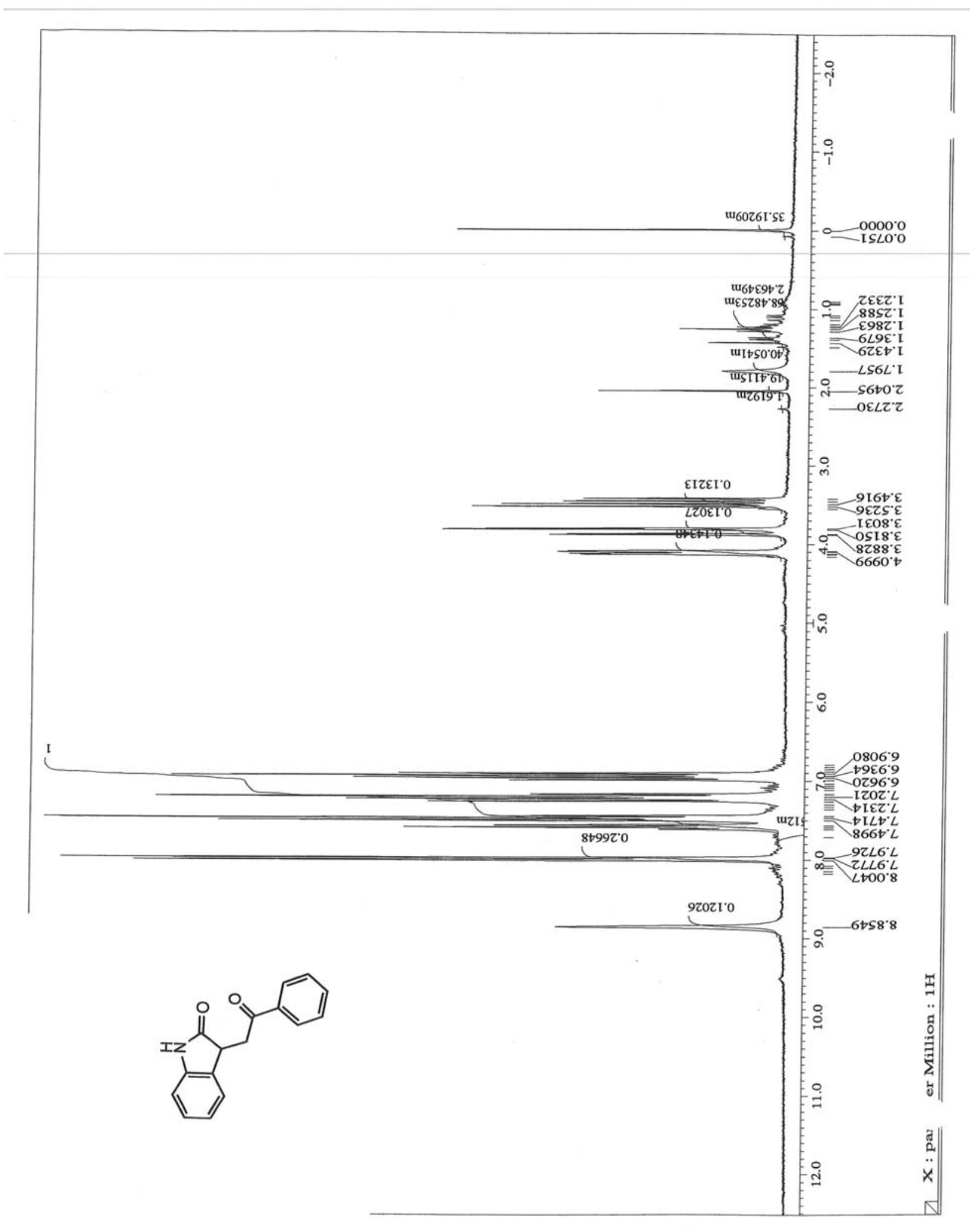

${ }^{1}$ H NMR 3-(2-phenyl-ethan-2-one)-indolin-2-one (75) 


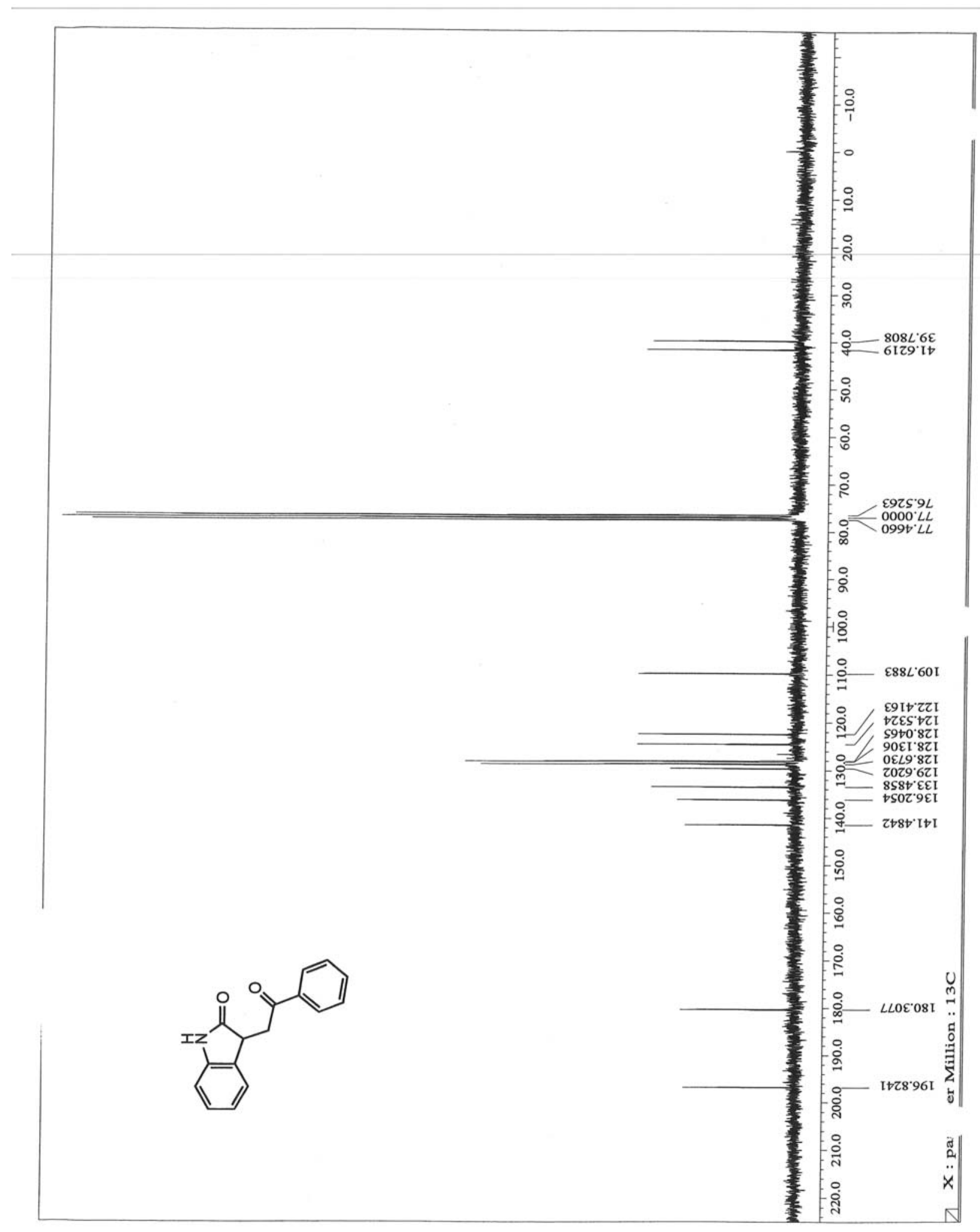

${ }^{13}$ C NMR 3-(2-phenyl-ethan-2-one)-indolin-2-one (75) 


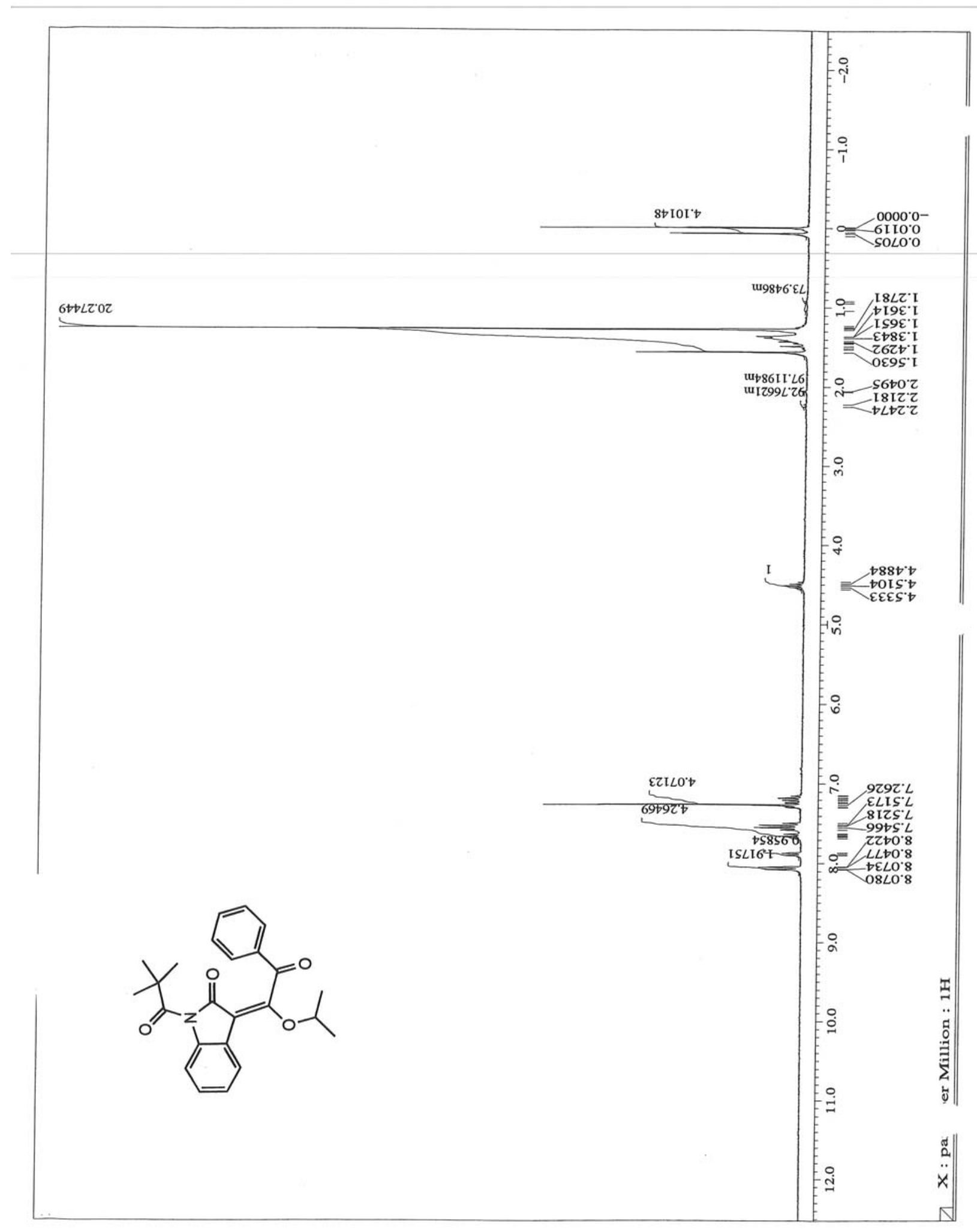

${ }^{1} \mathrm{H}$ NMR 3-(1-isopropoxy-2-oxo-2-phenylethylidene)-1-(pivaloyl)indolin-2-one (76) 


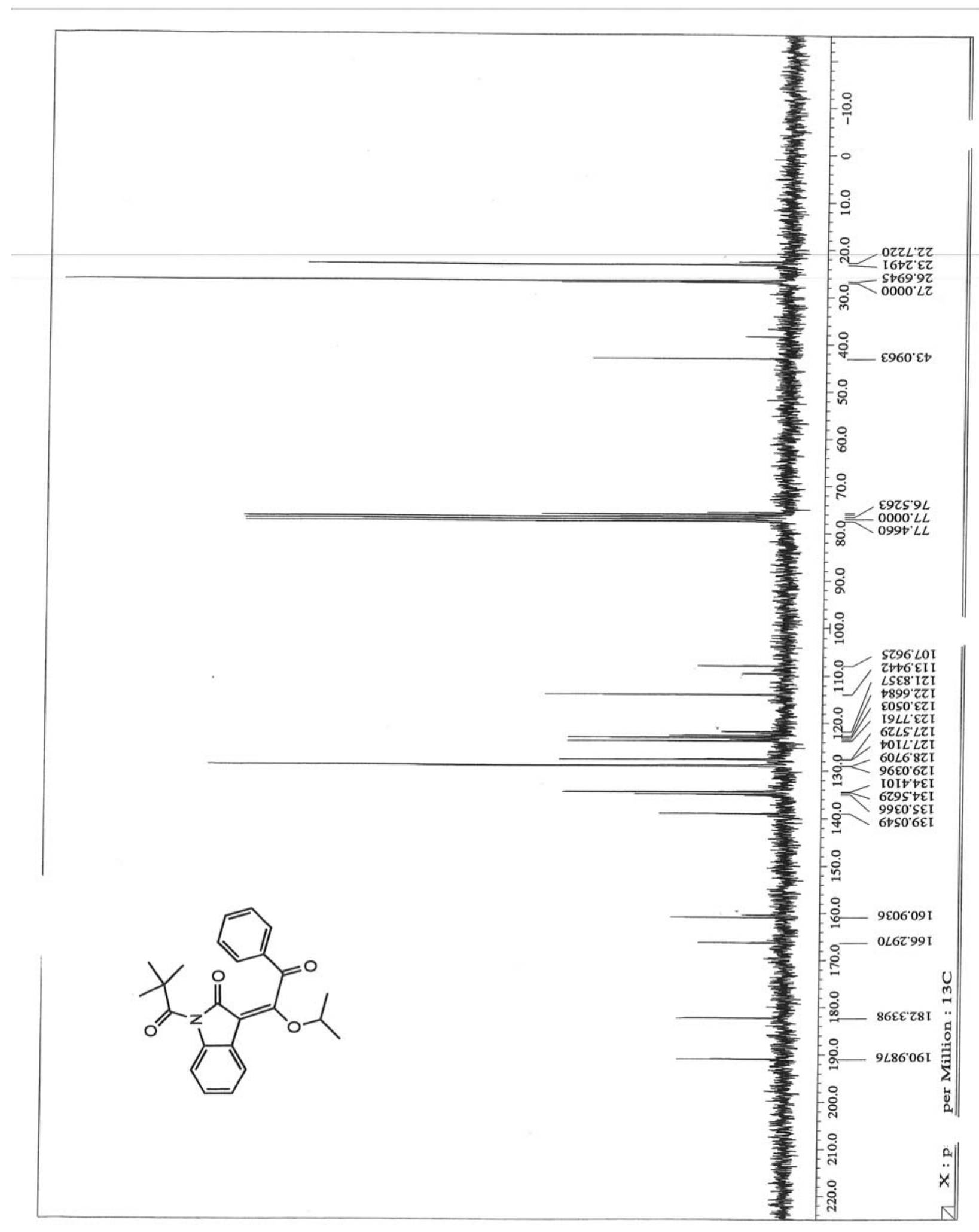

${ }^{13}$ C NMR 3-(1-isopropoxy-2-oxo-2-phenylethylidene)-1-(pivaloyl)indolin-2-one (76) 


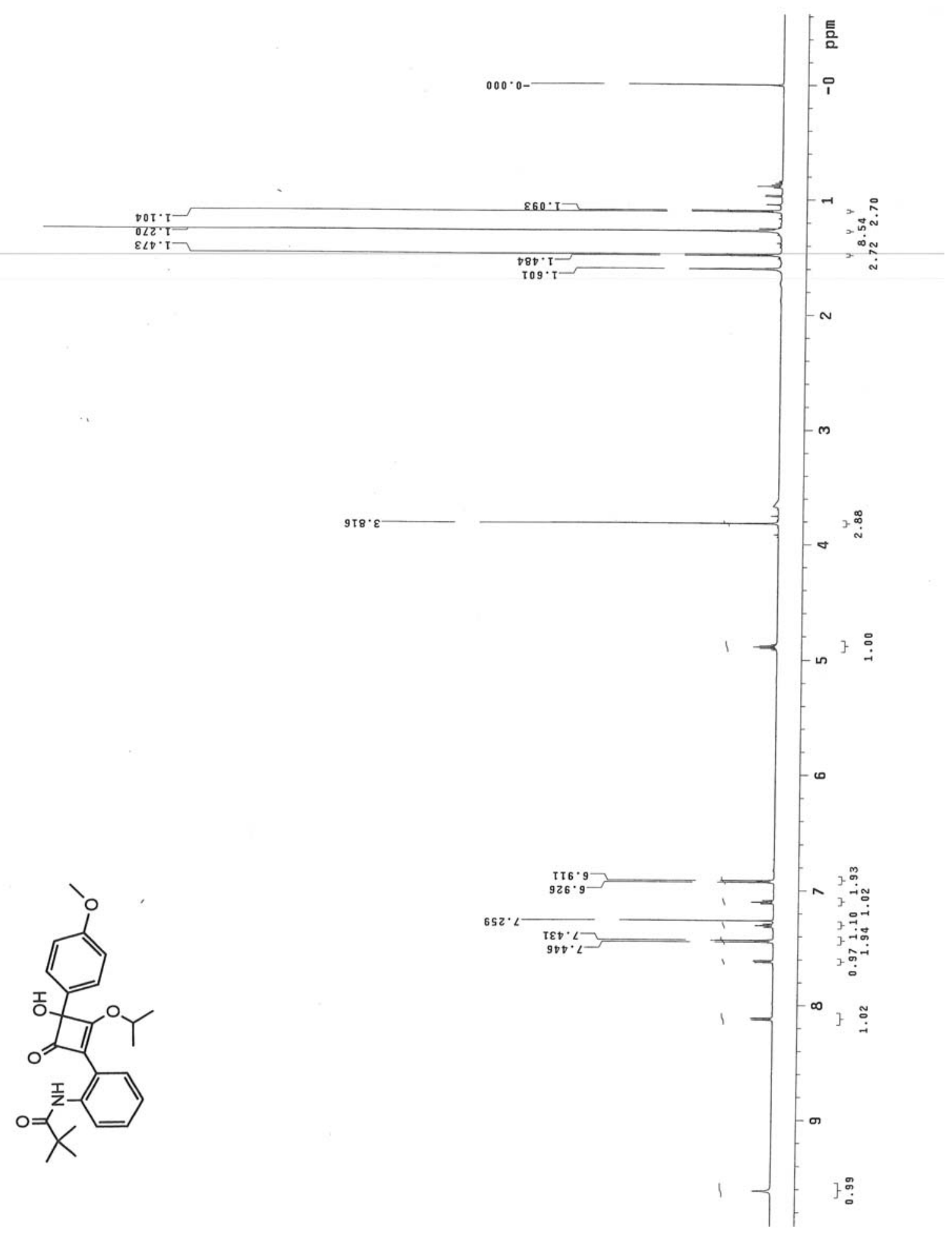

${ }^{1} \mathrm{H}$ NMR N-(2-(3-hydroxy-2-isopropoxy-3-(4-methoxyphenyl)-4-oxocyclobut-1enyl)phenyl)pivalamide (77) 


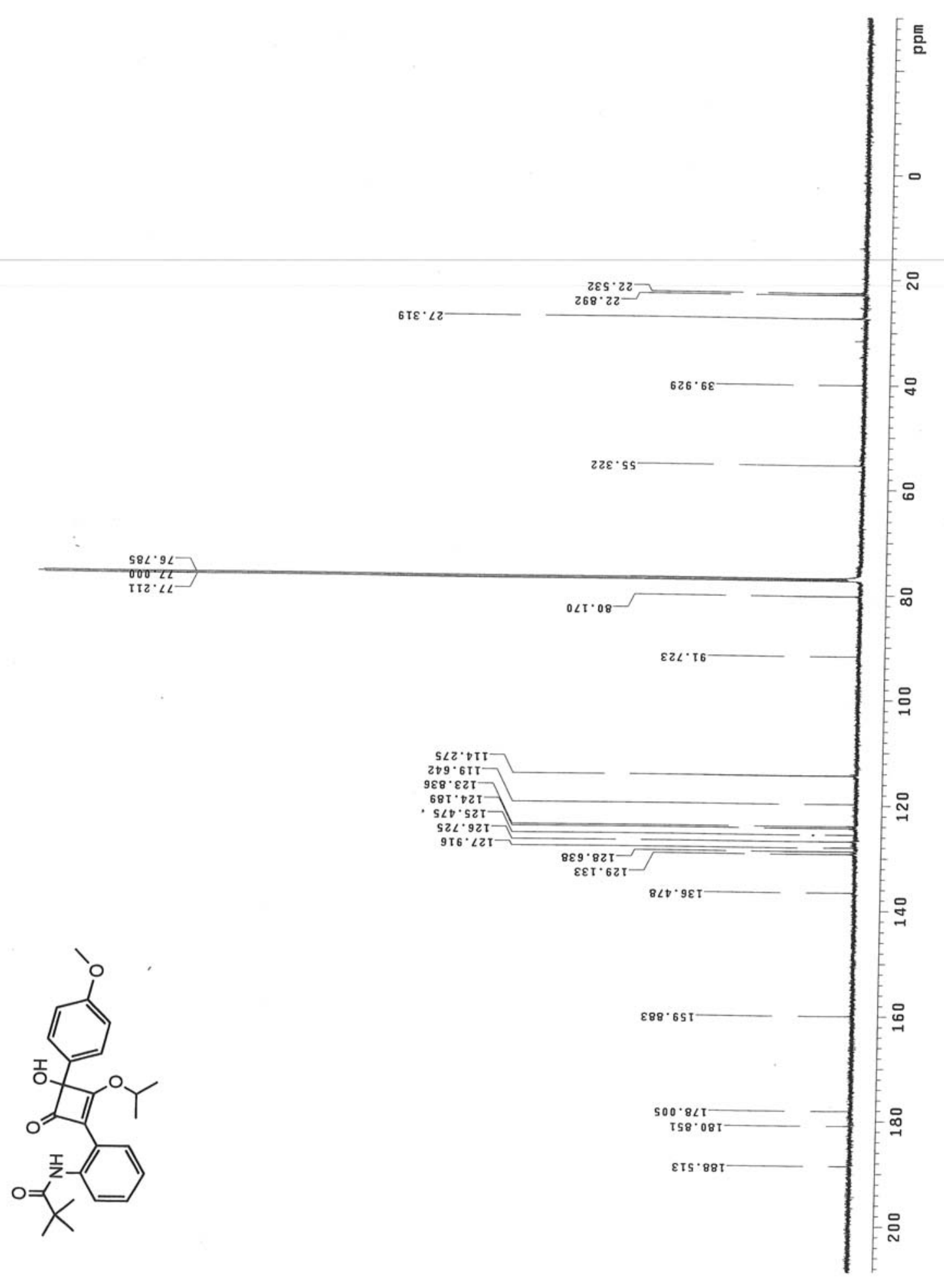

${ }^{13}$ C NMR N-(2-(3-hydroxy-2-isopropoxy-3-(4-methoxyphenyl)-4-oxocyclobut-1enyl)phenyl)pivalamide (77) 


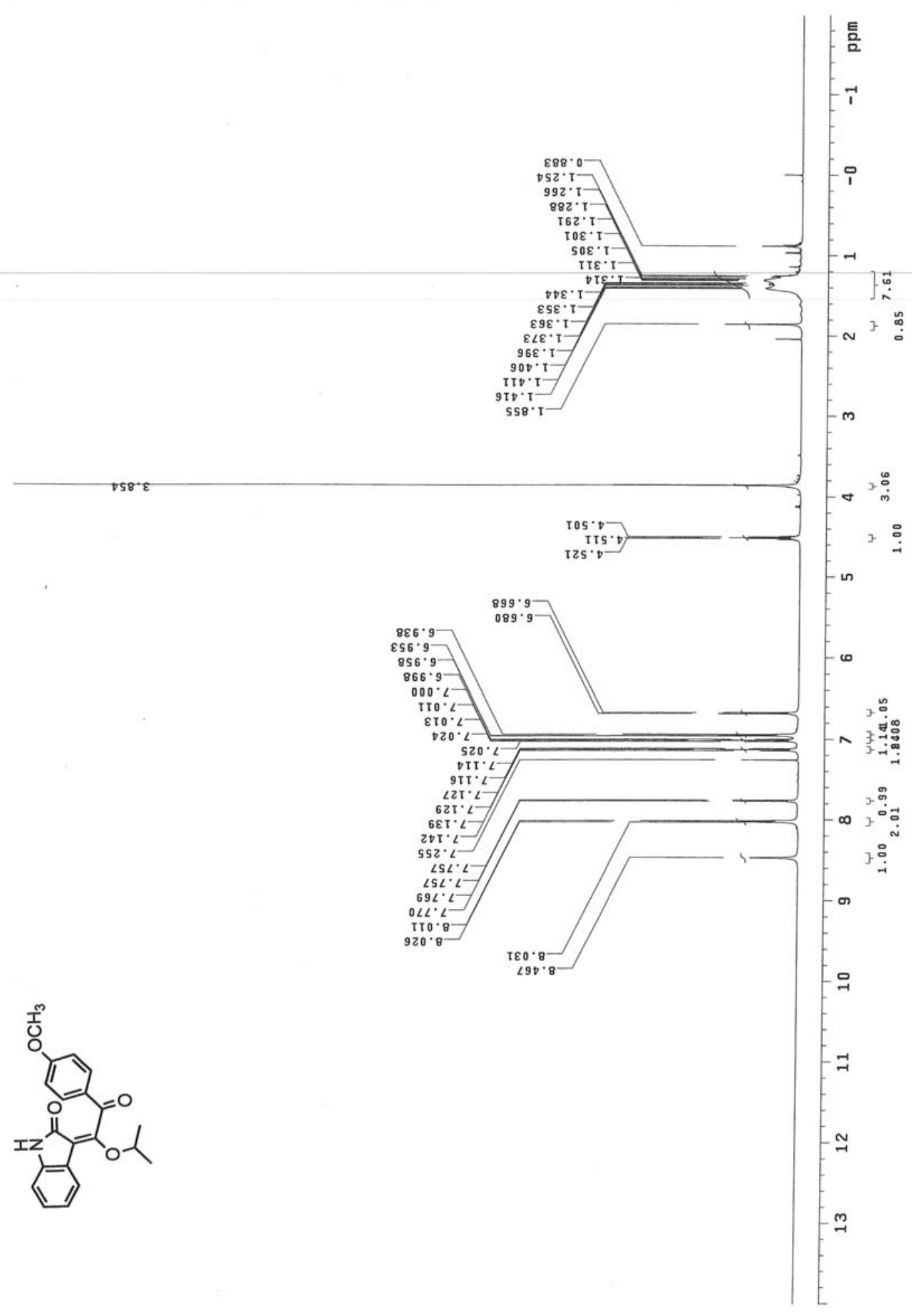

${ }^{1} \mathrm{H}$ NMR 3-(1-isopropoxy-2-(4-methoxyphenyl)-2-oxoethylidene)indolin-2-one (78) 


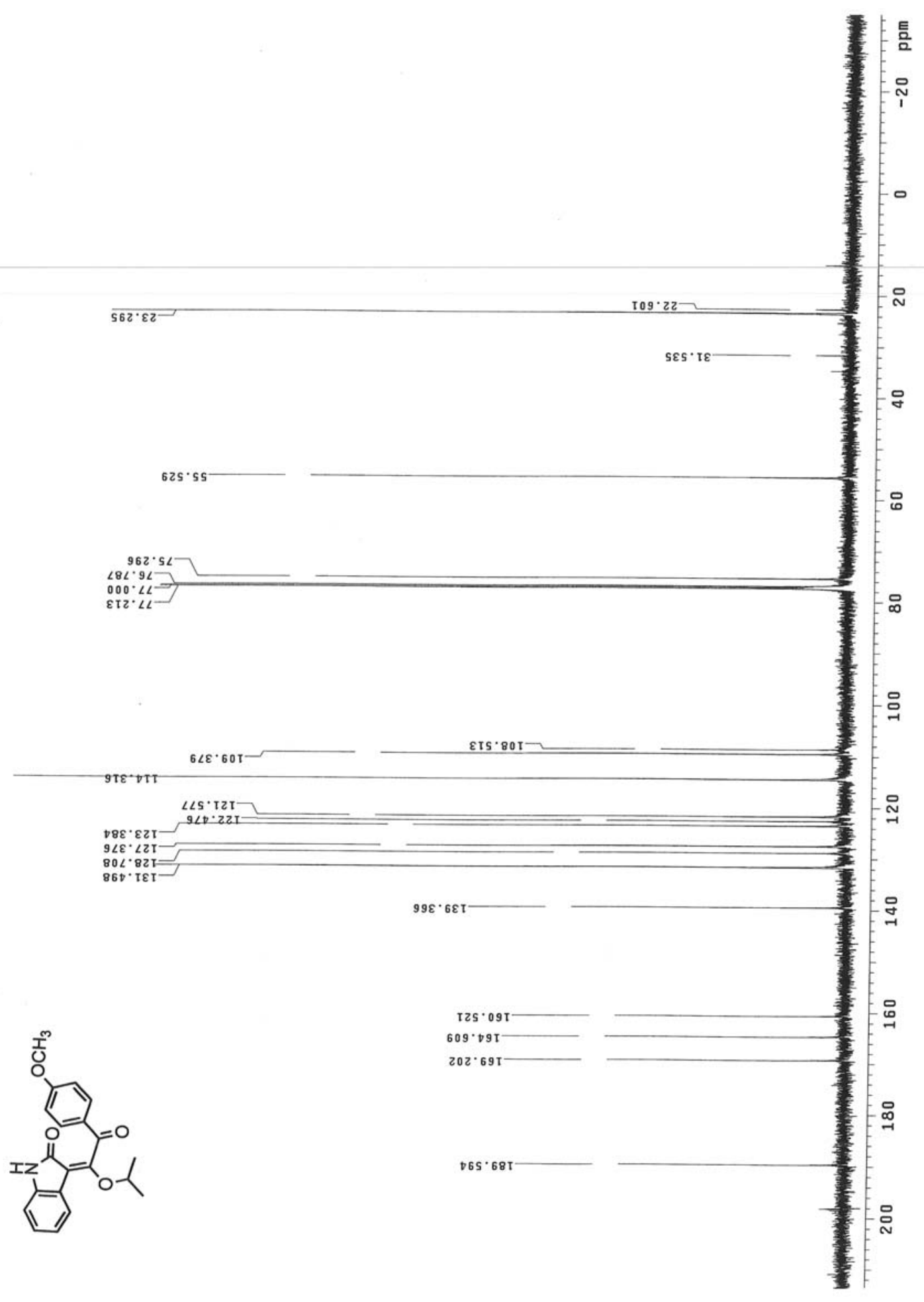

${ }^{13}$ C NMR 3-(1-isopropoxy-2-(4-methoxyphenyl)-2-oxoethylidene)indolin-2-one (78) 


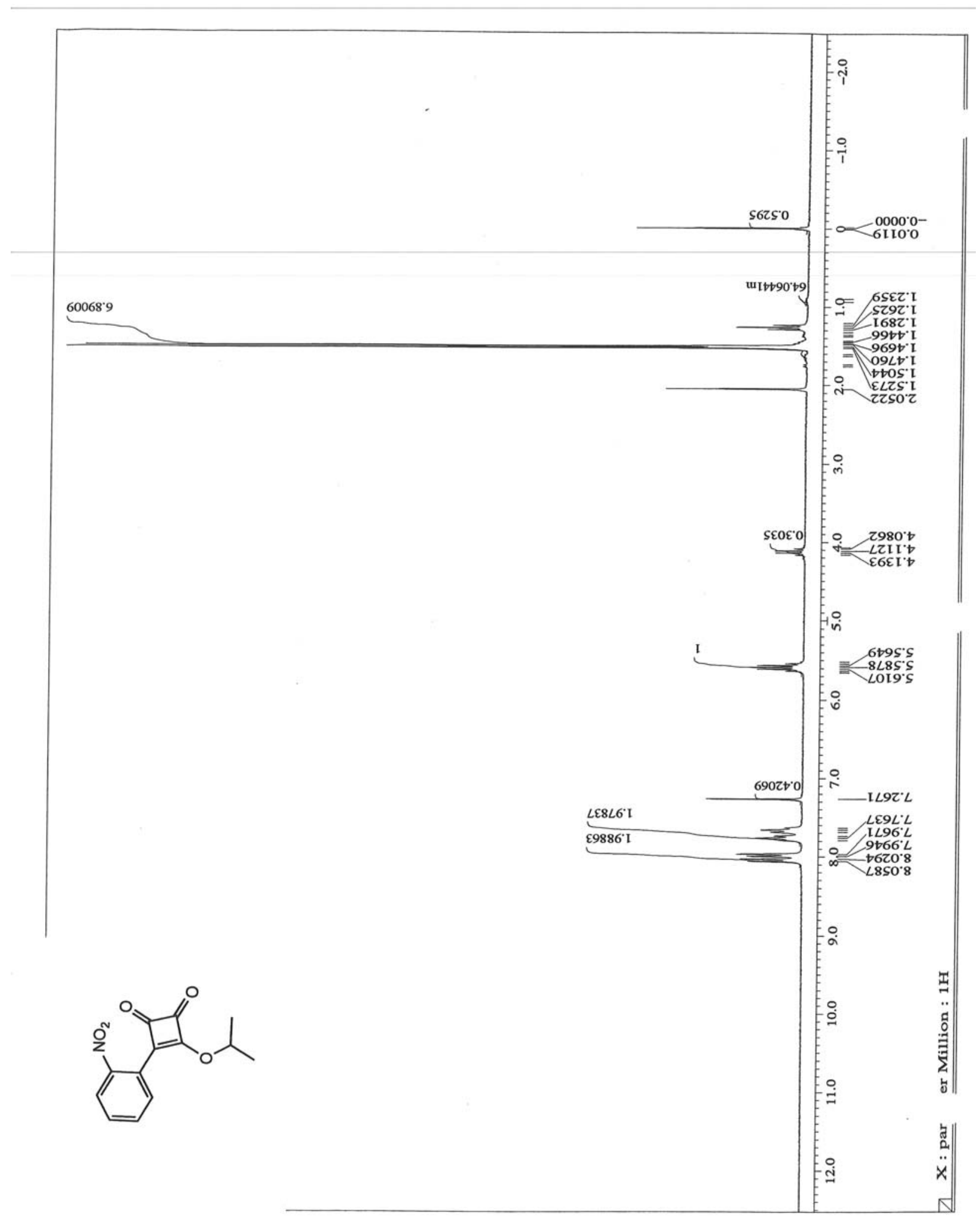

${ }^{1}$ H NMR 3-isopropoxy-4-(2-nitrophenyl)cyclobut-3-ene-1,2-dione (81) 


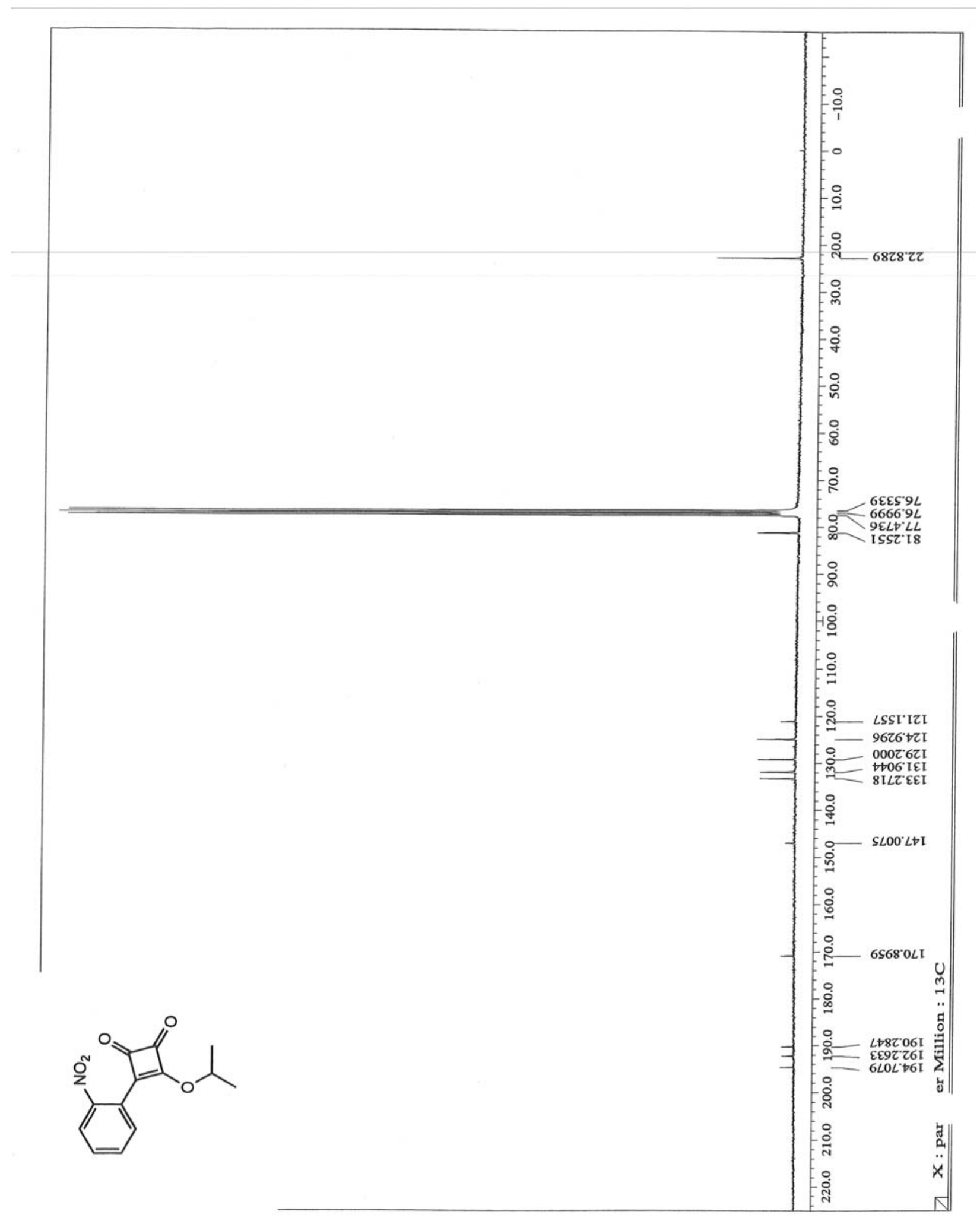

${ }^{13}$ C NMR 3-isopropoxy-4-(2-nitrophenyl)cyclobut-3-ene-1,2-dione (81) 


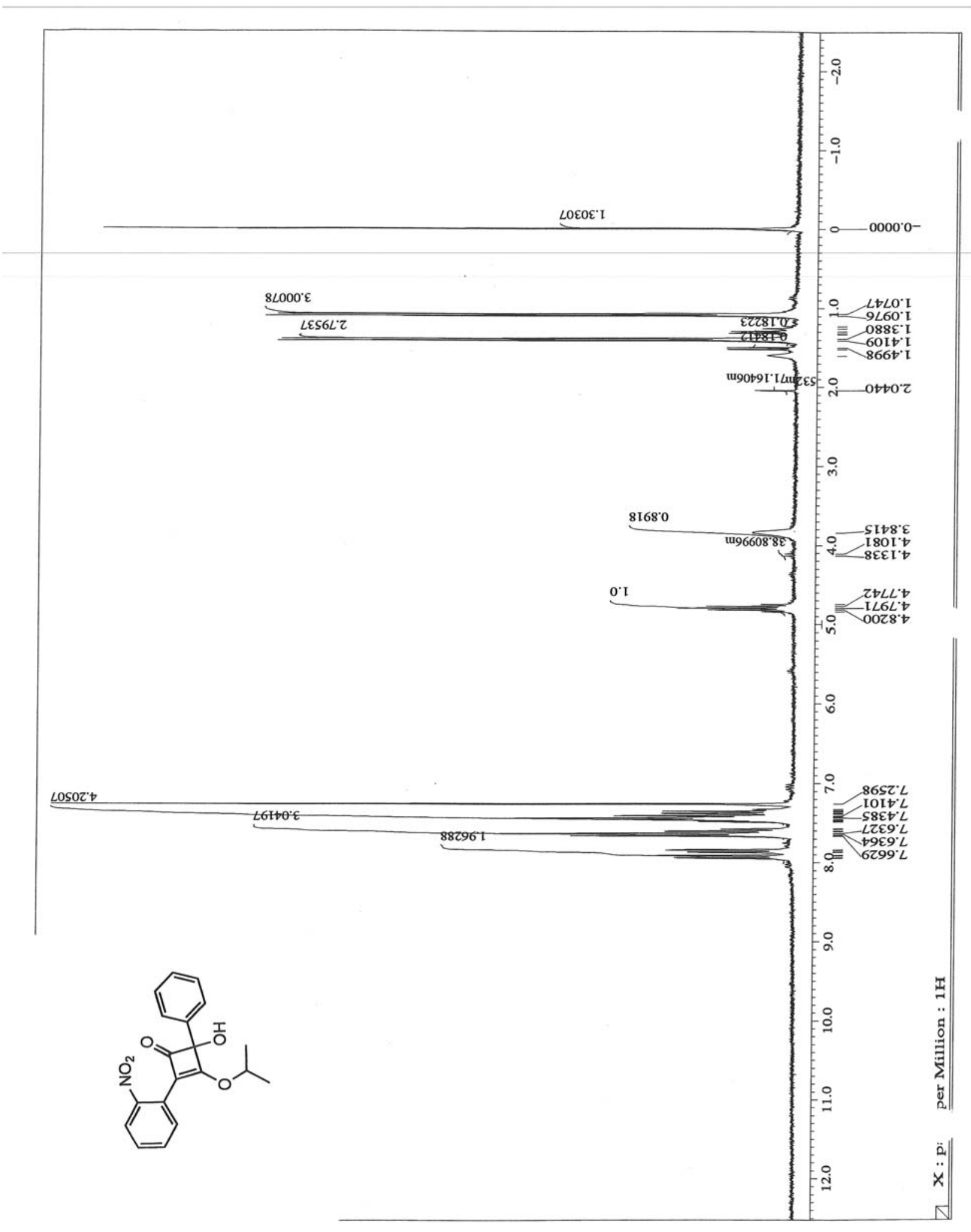

${ }^{1} \mathrm{H}$ NMR 4-hydroxy-3-isopropoxy-2-(2-nitrophenyl)-4-phenylcyclobut-2-enone (82) 


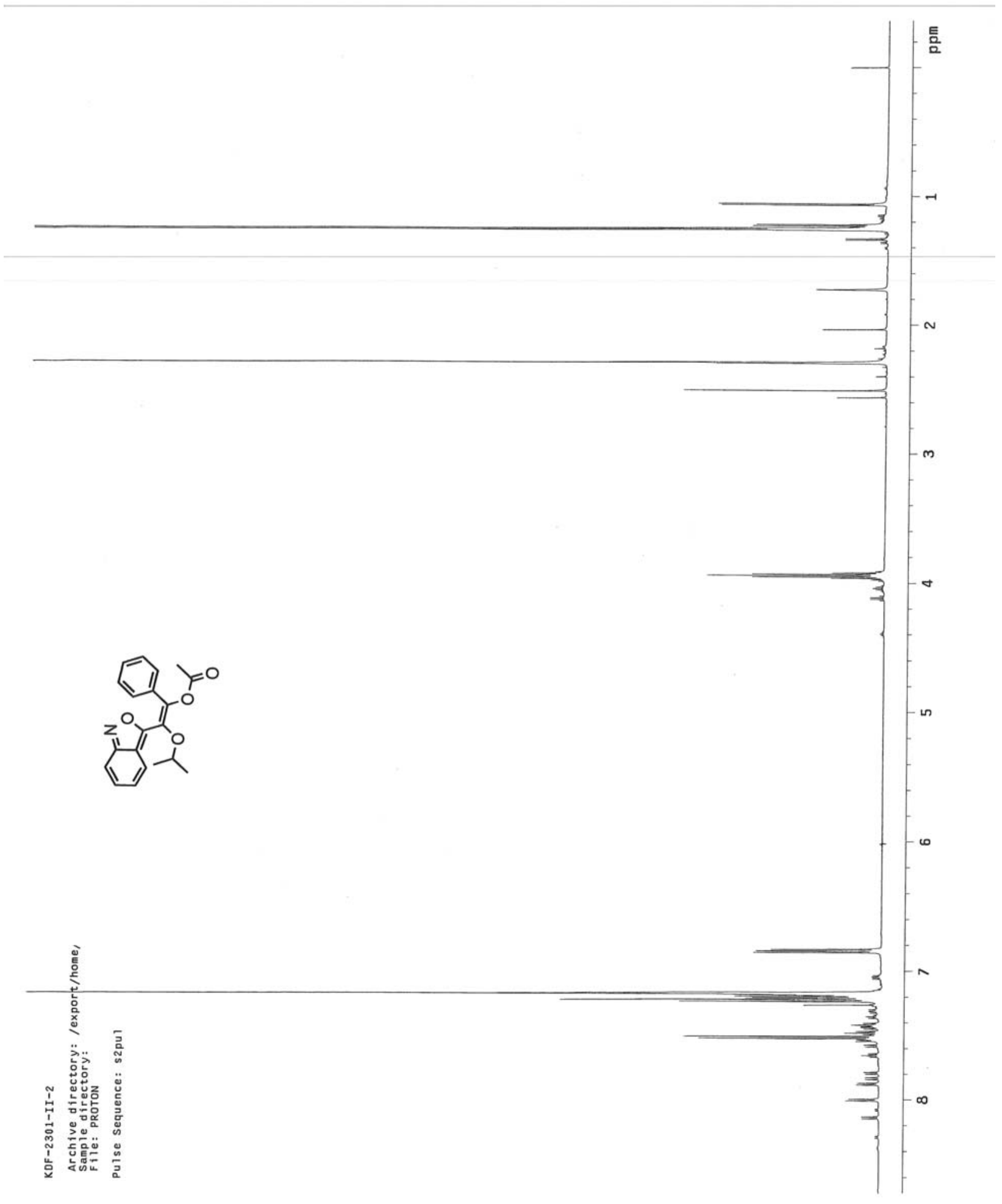

${ }^{1}$ H NMR 2-(benzo[c]isoxazol-3-yl)-2-isopropoxy-1-phenylvinyl acetate (85) 


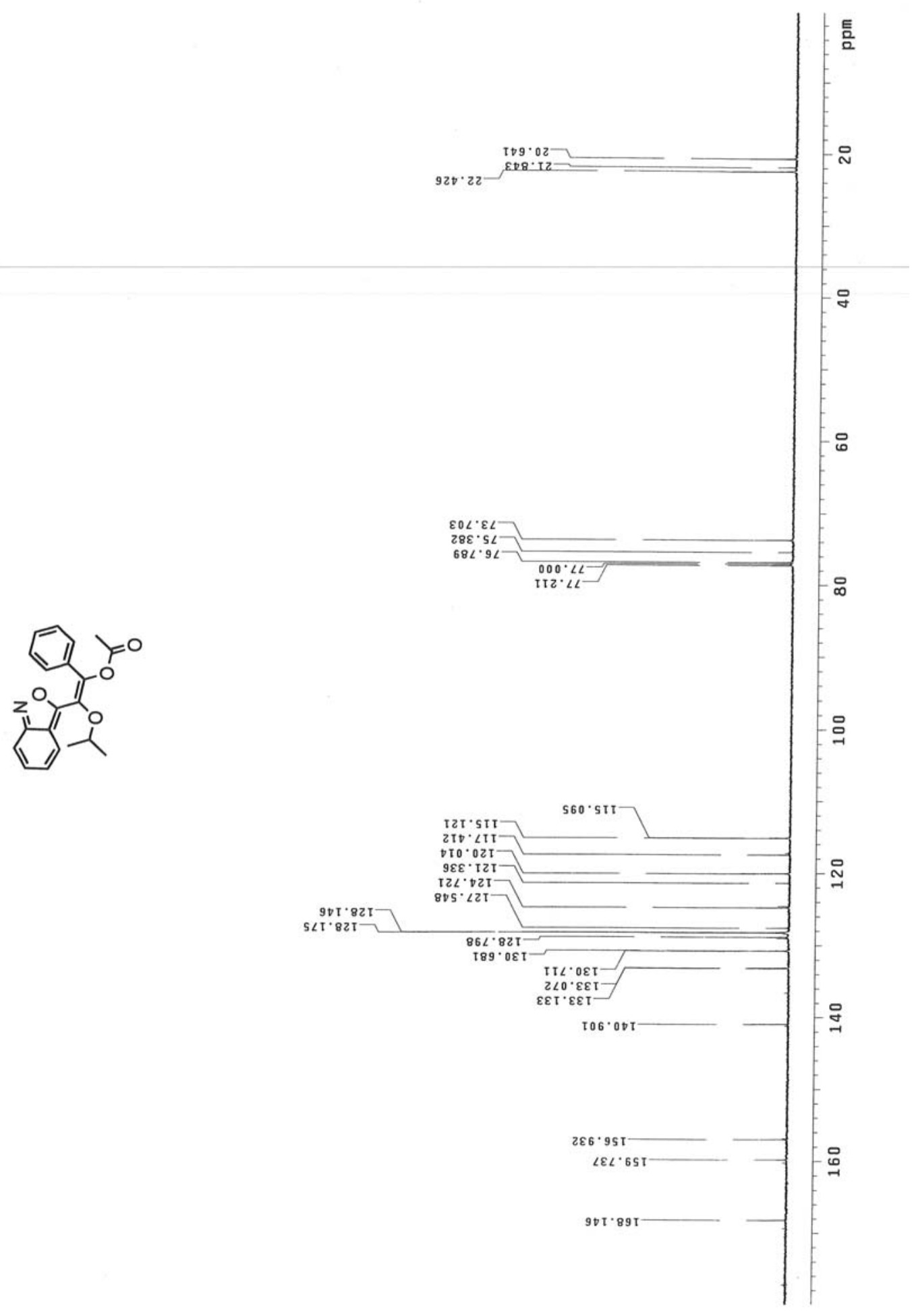

${ }^{13}$ C NMR 2-(benzo[c]isoxazol-3-yl)-2-isopropoxy-1-phenylvinyl acetate (85) 


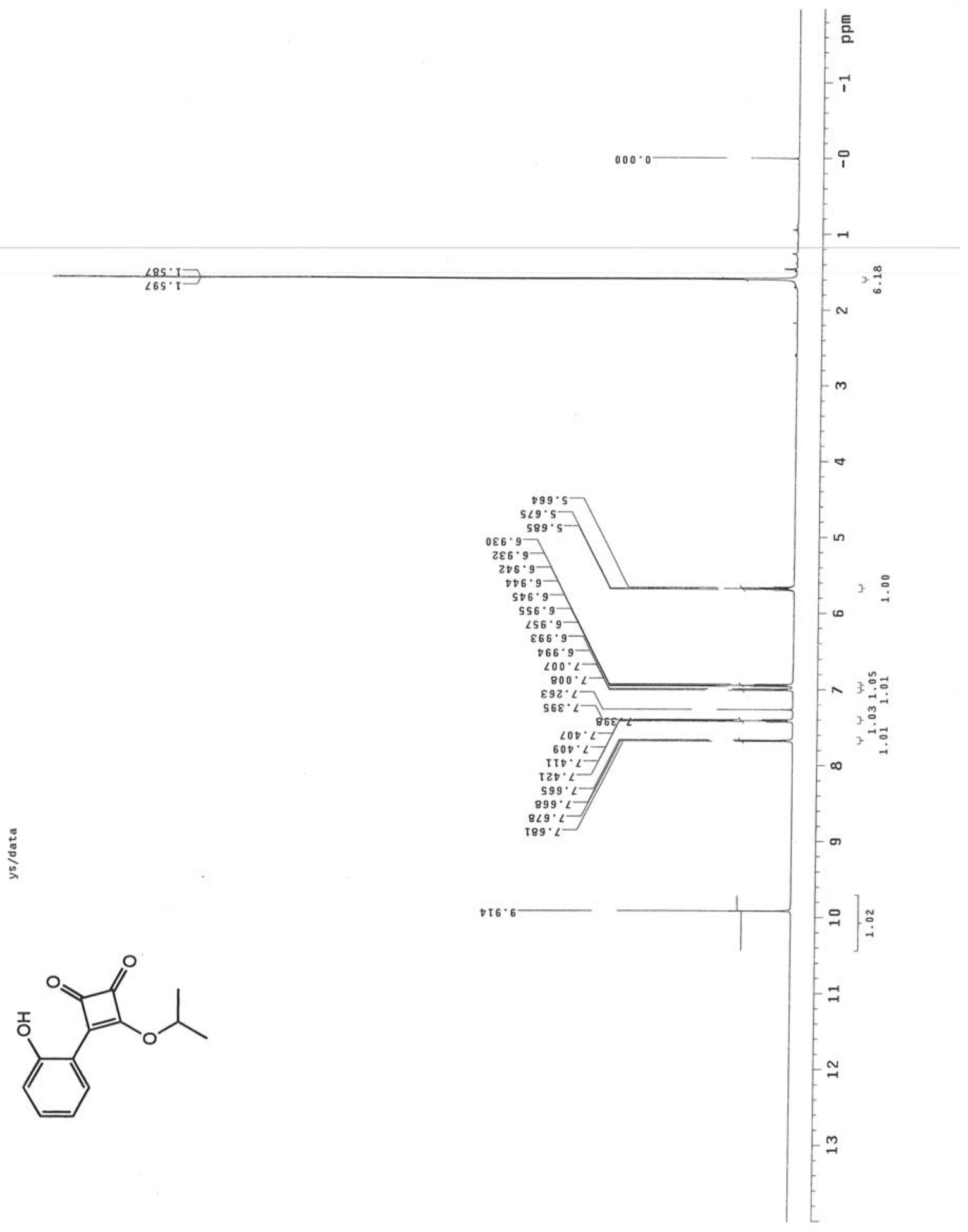

${ }^{1}$ H NMR 3-(2-hydroxyphenyl)-4-isopropoxycyclobut-3-ene-1,2-dione (93) 


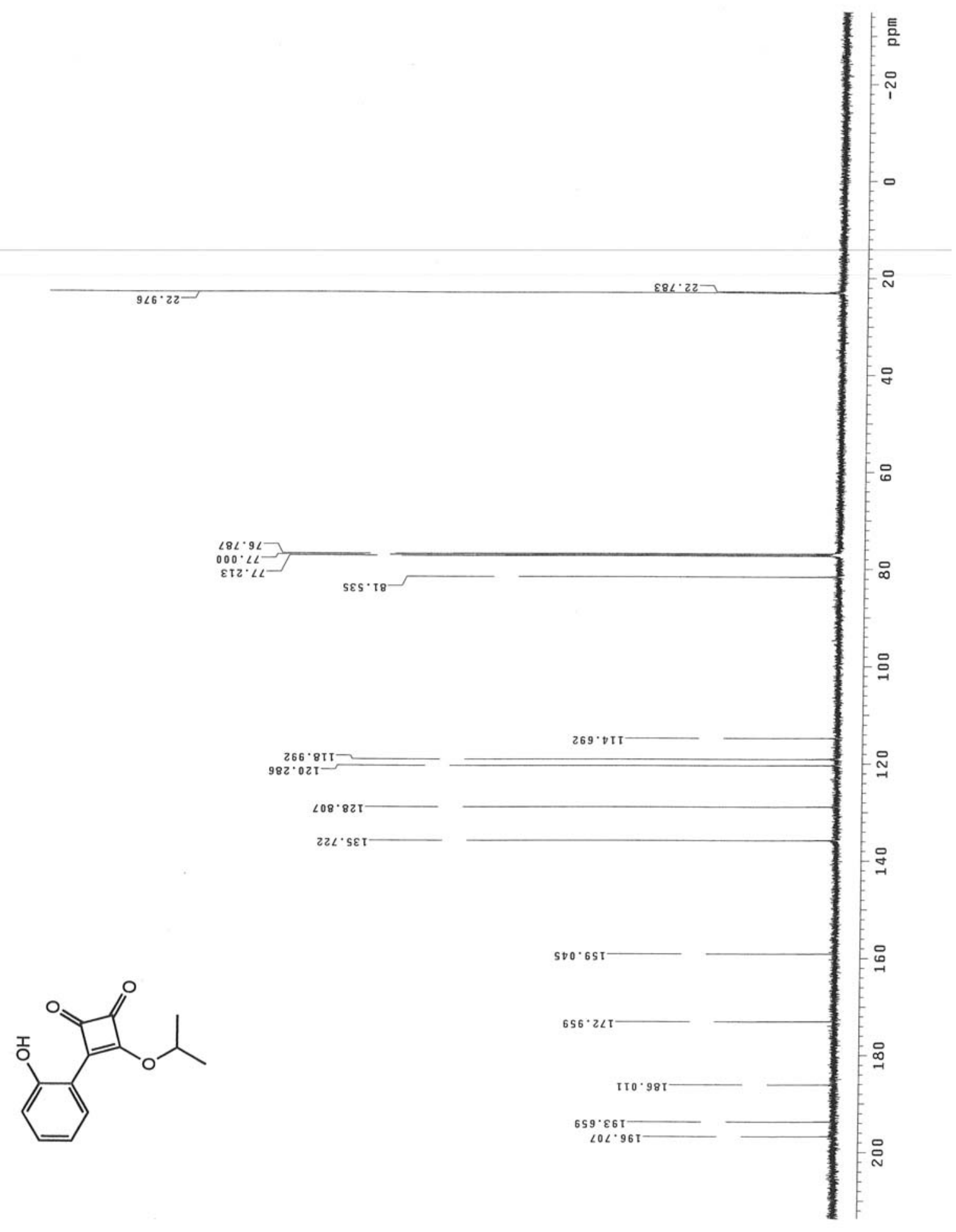

${ }^{13}$ C NMR 3-(2-hydroxyphenyl)-4-isopropoxycyclobut-3-ene-1,2-dione (93) 


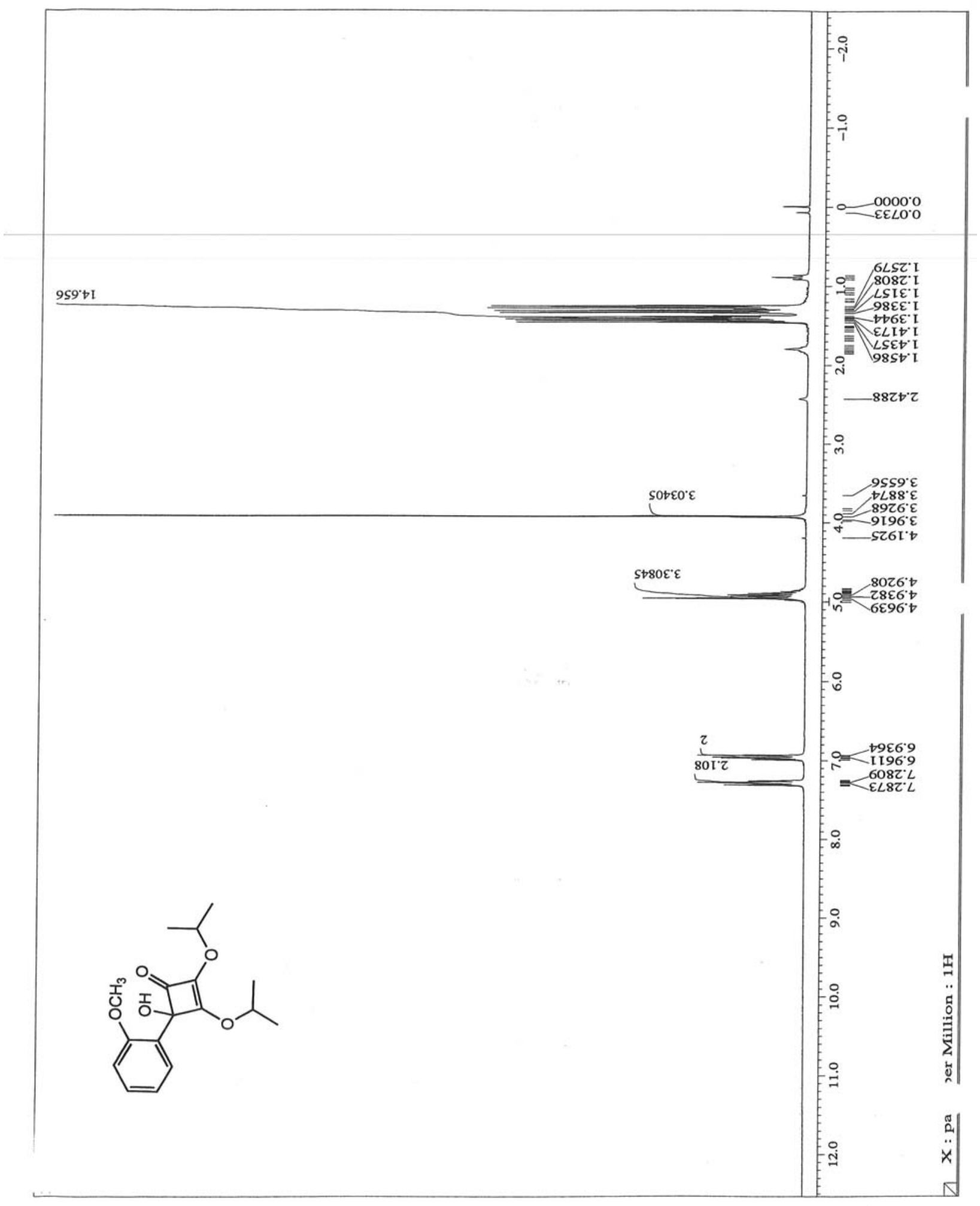

${ }^{1}$ H NMR 4-hydroxy-2,3-diisopropoxy-4-(2-methoxyphenyl)cyclobut-2-enone (94) 


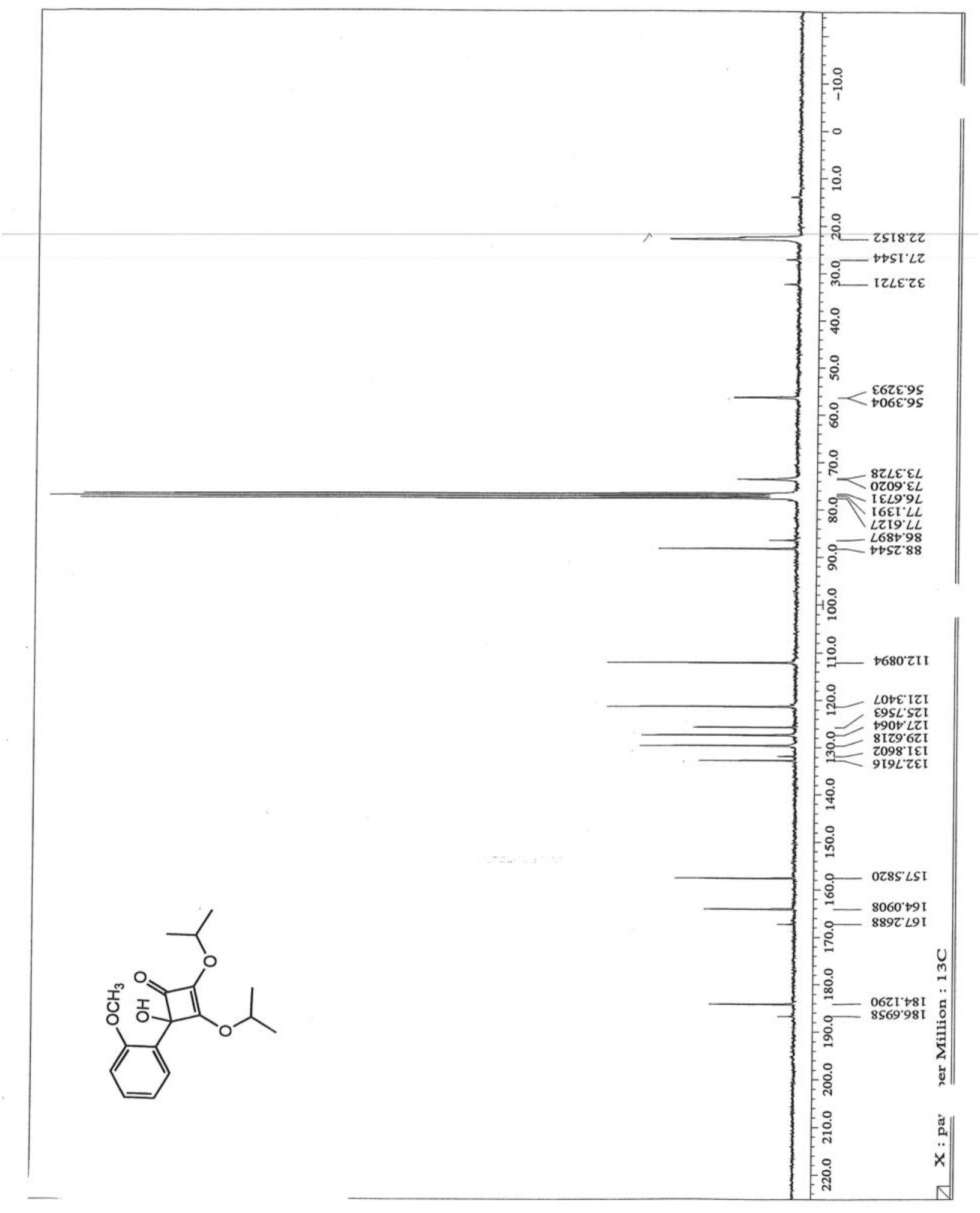

${ }^{13}$ C NMR 4-hydroxy-2,3-diisopropoxy-4-(2-methoxyphenyl)cyclobut-2-enone (94) 


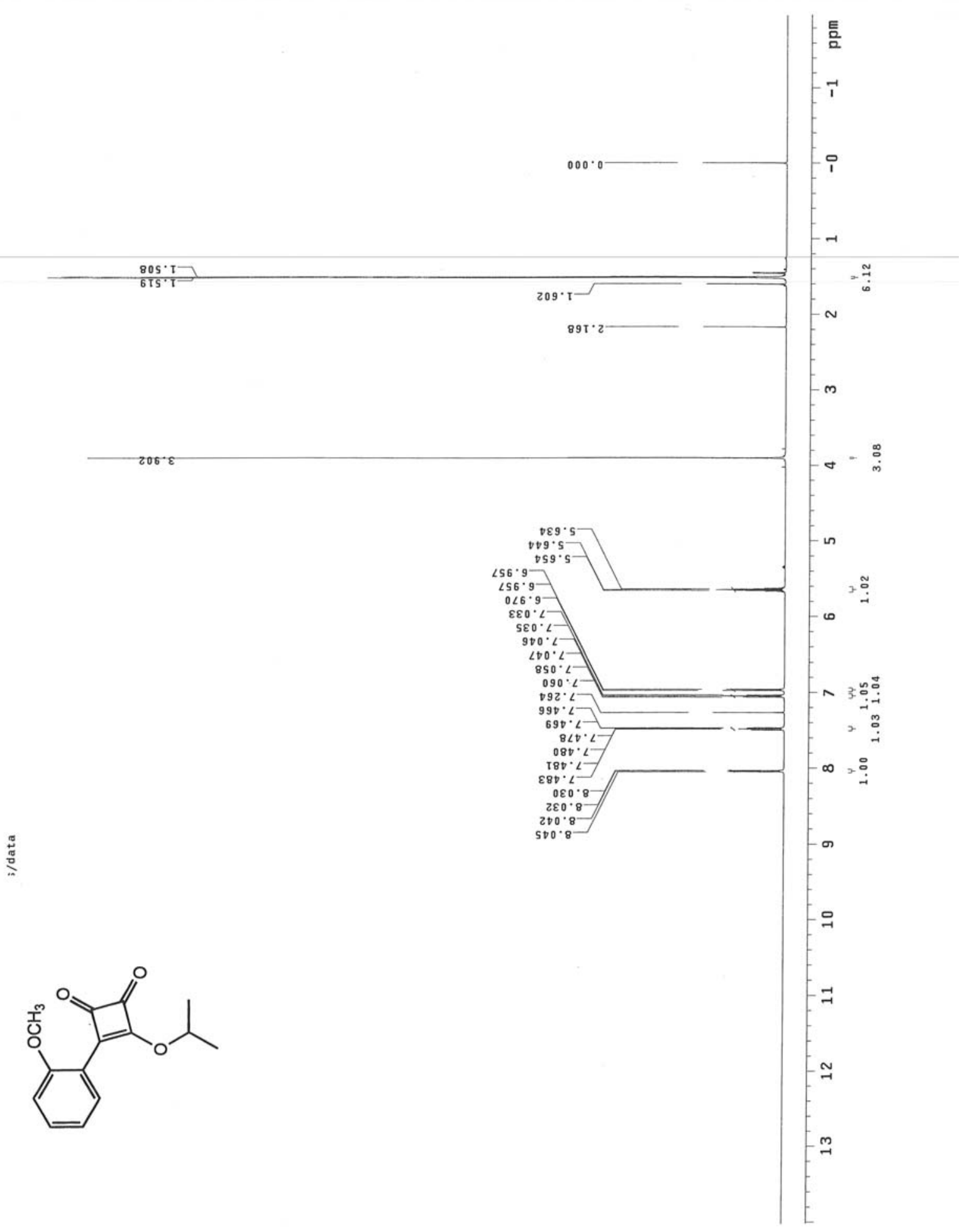

${ }^{1}$ H NMR 3-isopropoxy-4-(2-methoxyphenyl)cyclobut-3-ene-1,2-dione (96) 


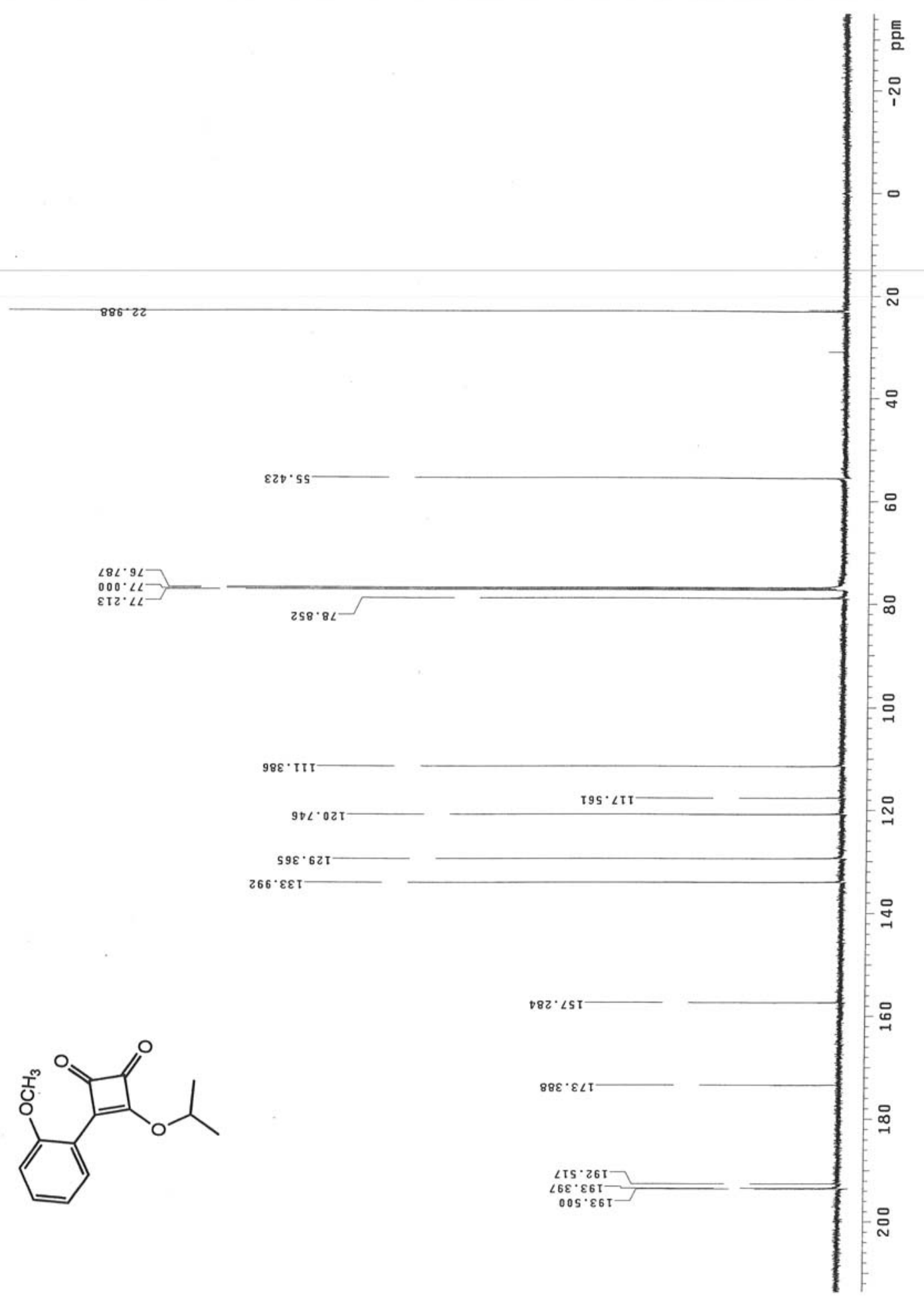

${ }^{13}$ C NMR 3-isopropoxy-4-(2-methoxyphenyl)cyclobut-3-ene-1,2-dione (96) 


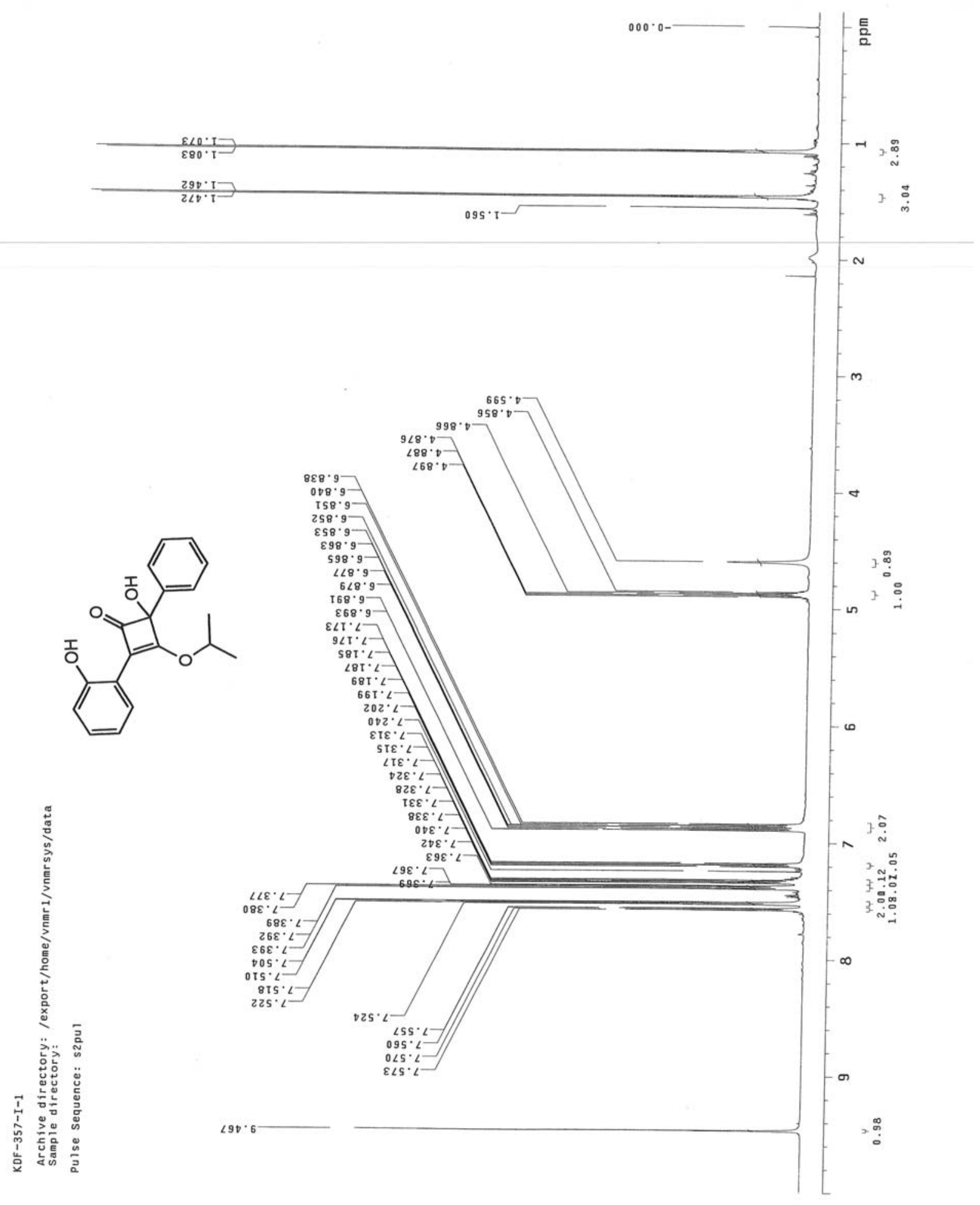

${ }^{1}$ H NMR 4-hydroxy-2-(2-hydroxyphenyl)-3-isopropoxy-4-phenylcyclobut-2-enone (97) 


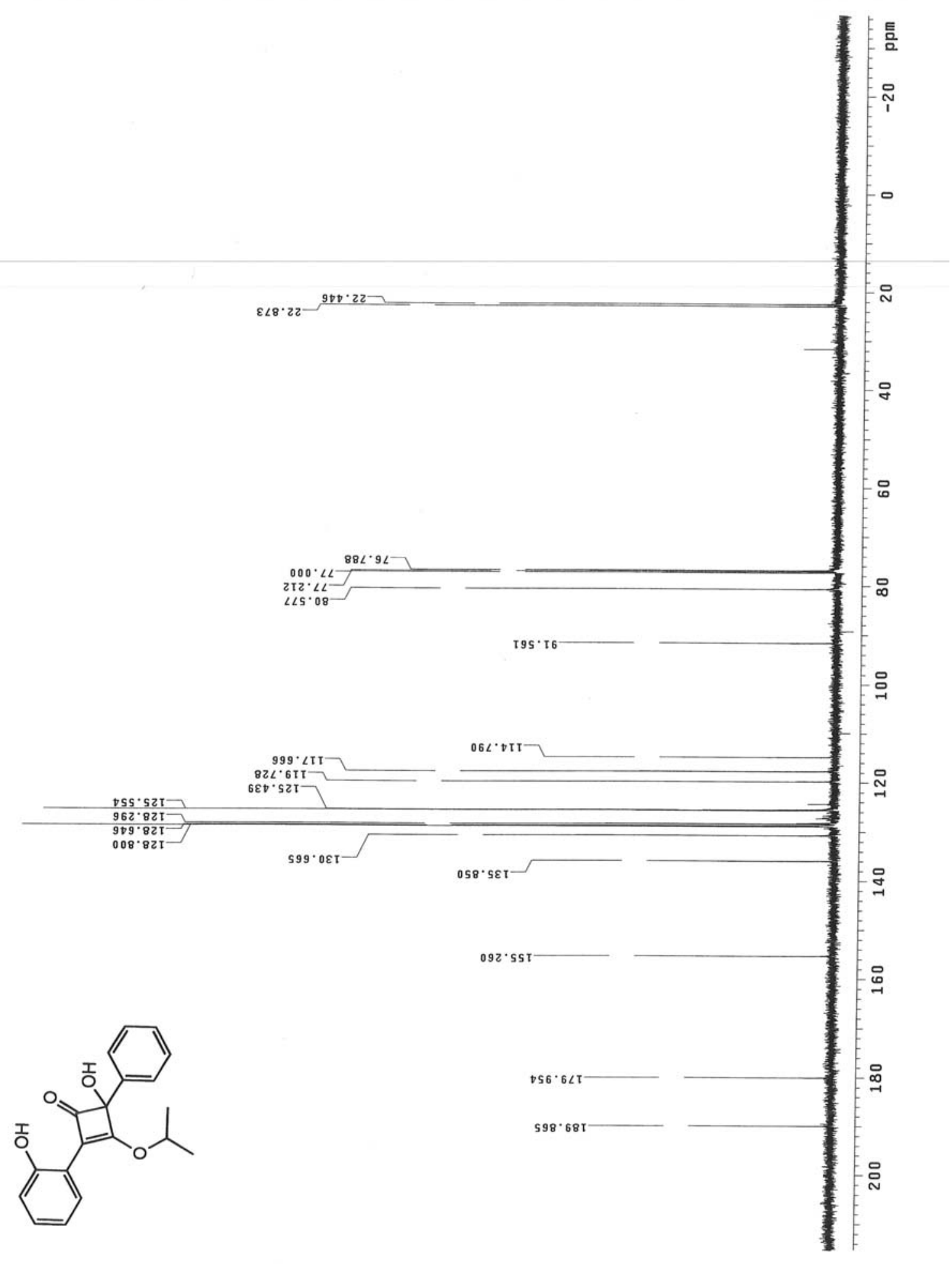

${ }^{13}$ C NMR 4-hydroxy-2-(2-hydroxyphenyl)-3-isopropoxy-4-phenylcyclobut-2-enone (97) 


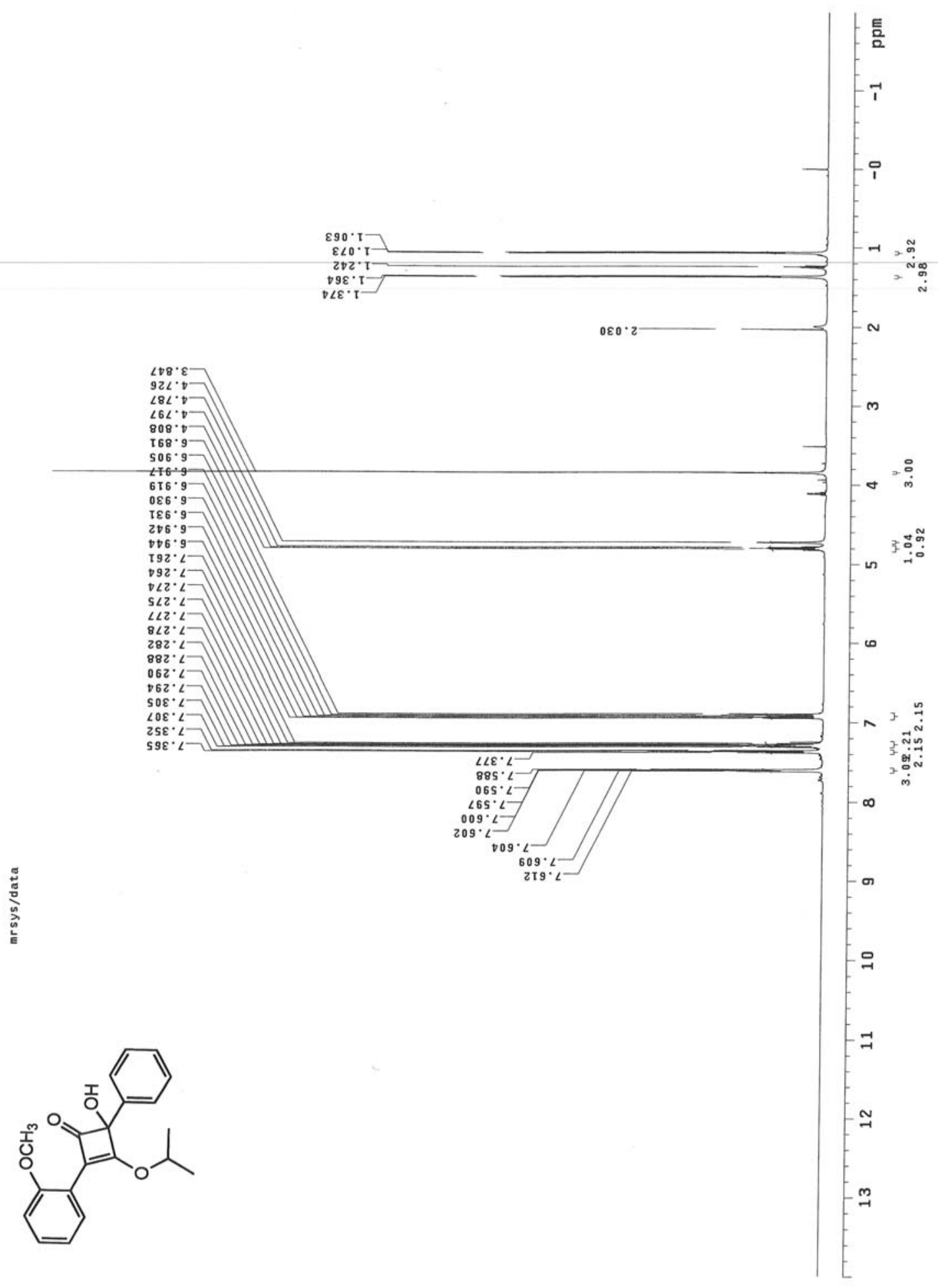

${ }^{1}$ H NMR 4-hydroxy-3-isopropoxy-2-(2-methoxyphenyl)-4-phenylcyclobut-2-enone (99) 


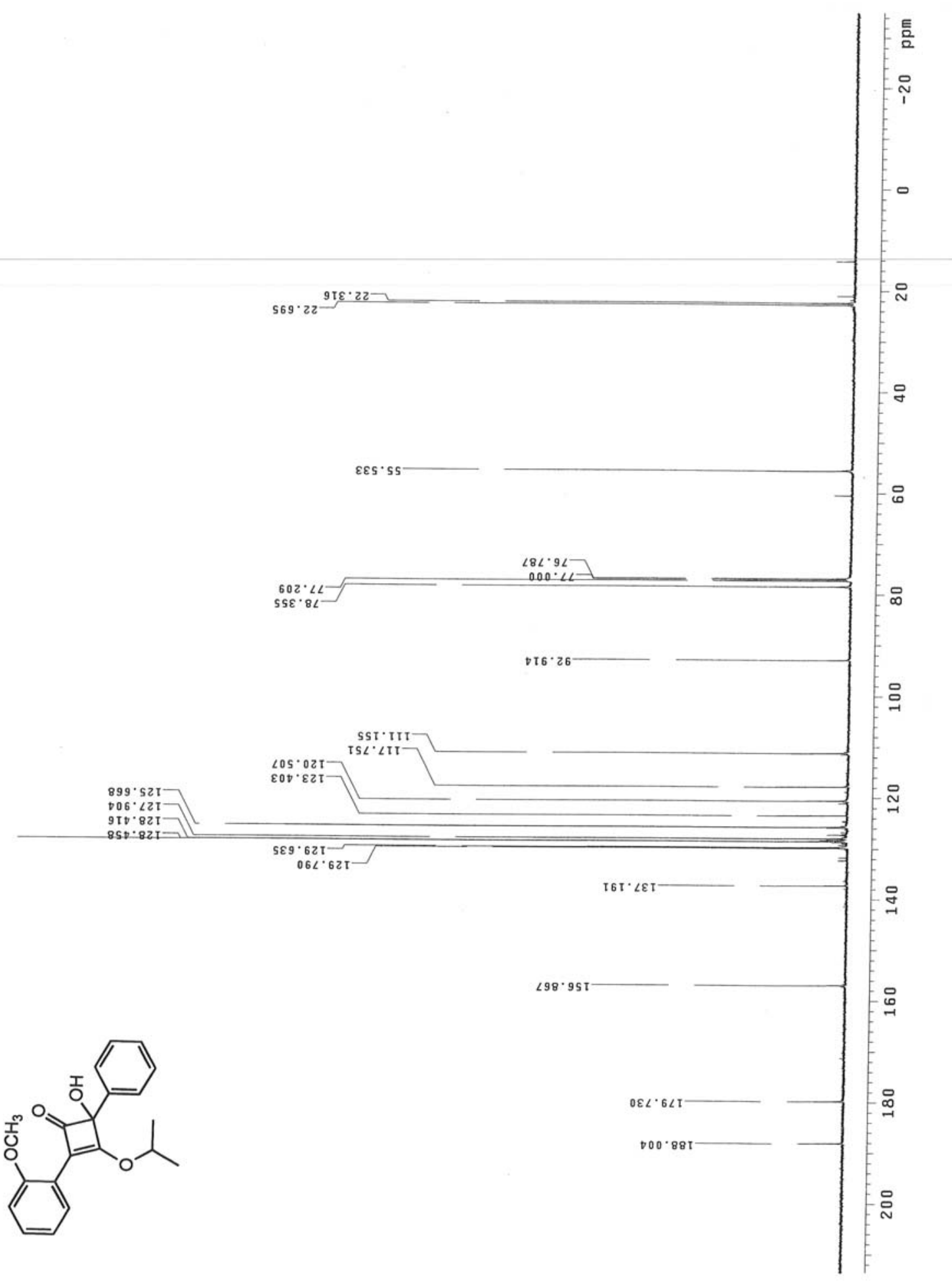

${ }^{13}$ C NMR 4-hydroxy-3-isopropoxy-2-(2-methoxyphenyl)-4-phenylcyclobut-2-enone (99) 


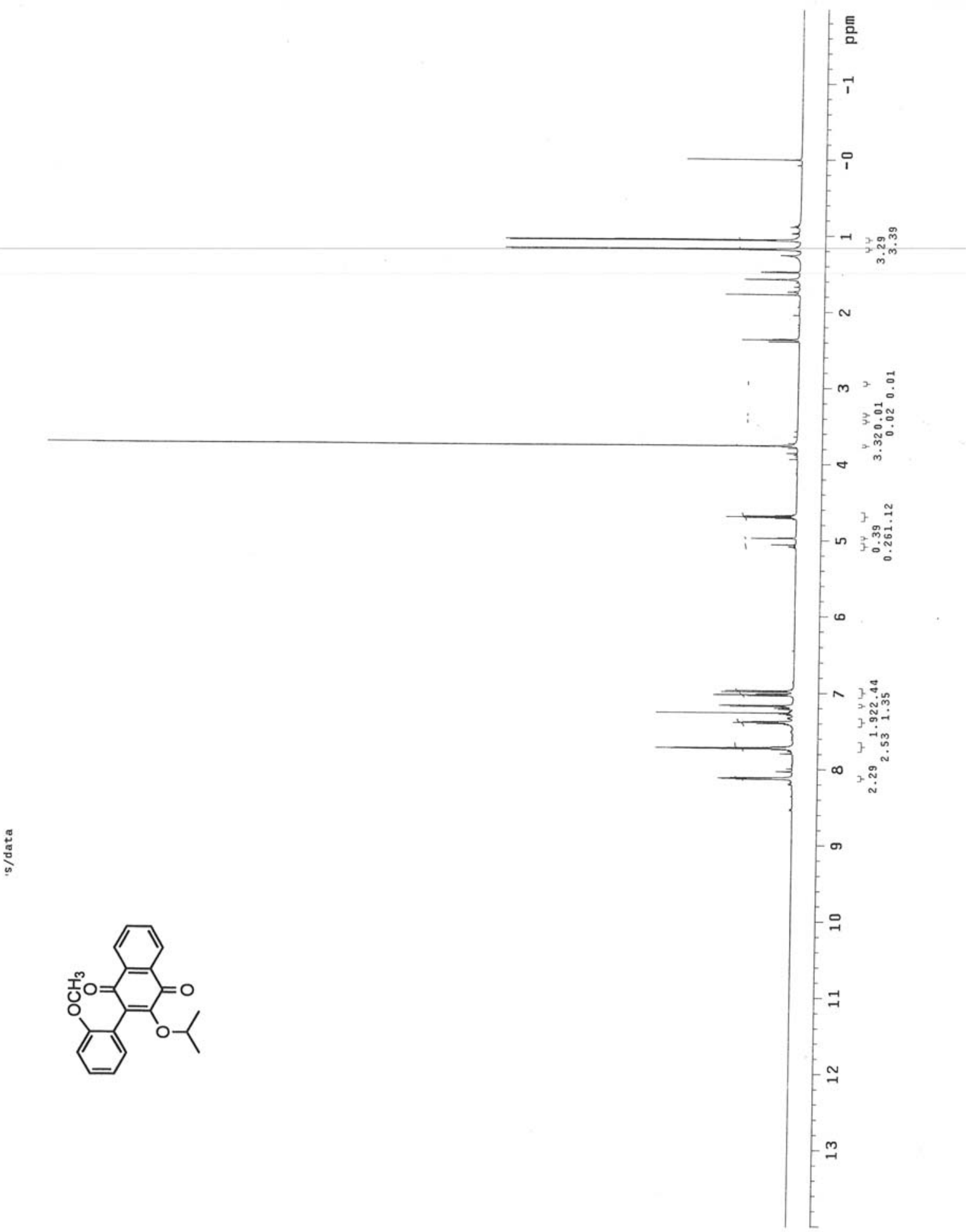

${ }^{1}$ H NMR 2-isopropoxy-3-(2-methoxyphenyl)naphthalene-1,4-dione (100) 


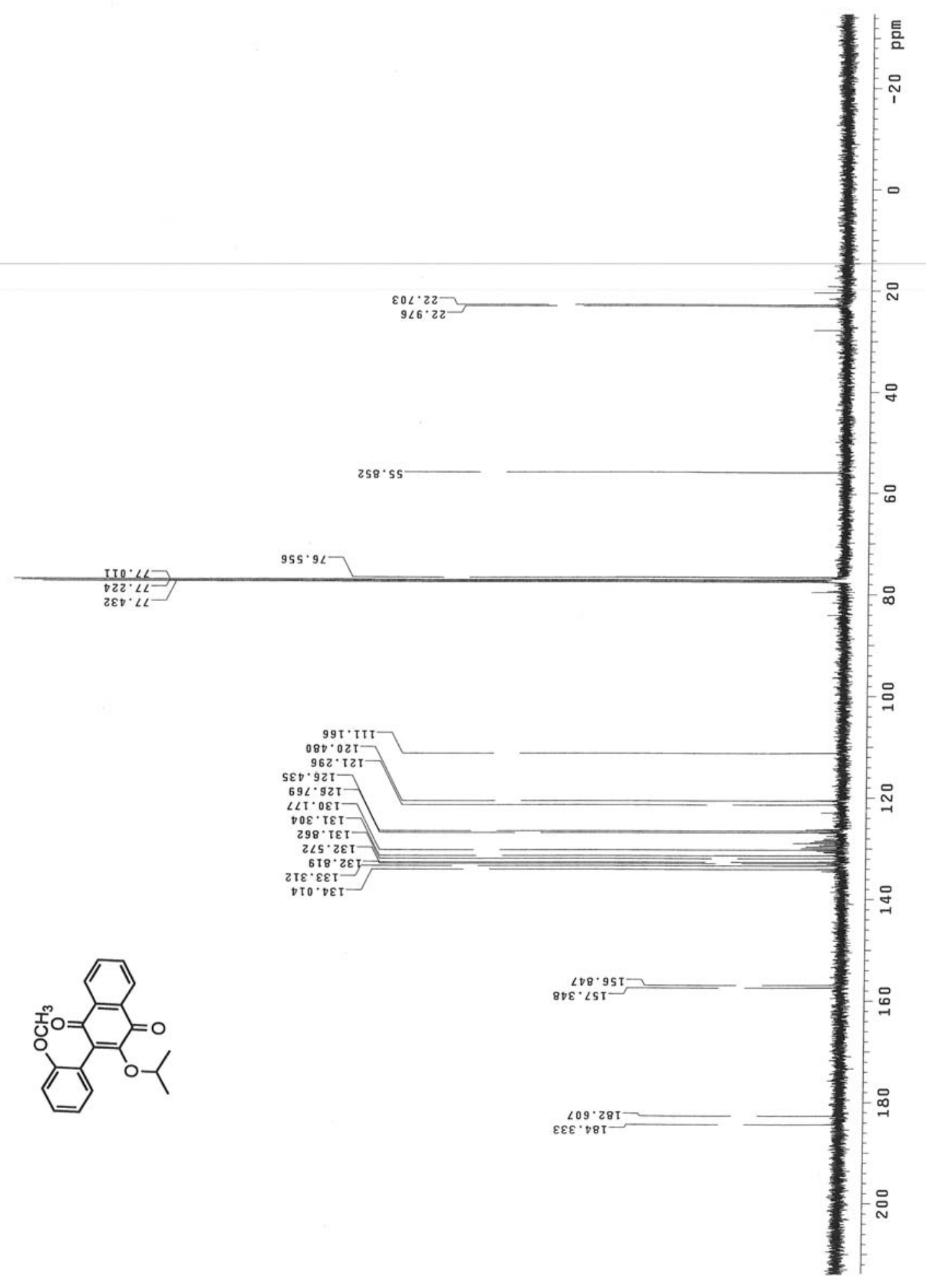

${ }^{13}$ C NMR 2-isopropoxy-3-(2-methoxyphenyl)naphthalene-1,4-dione (100) 


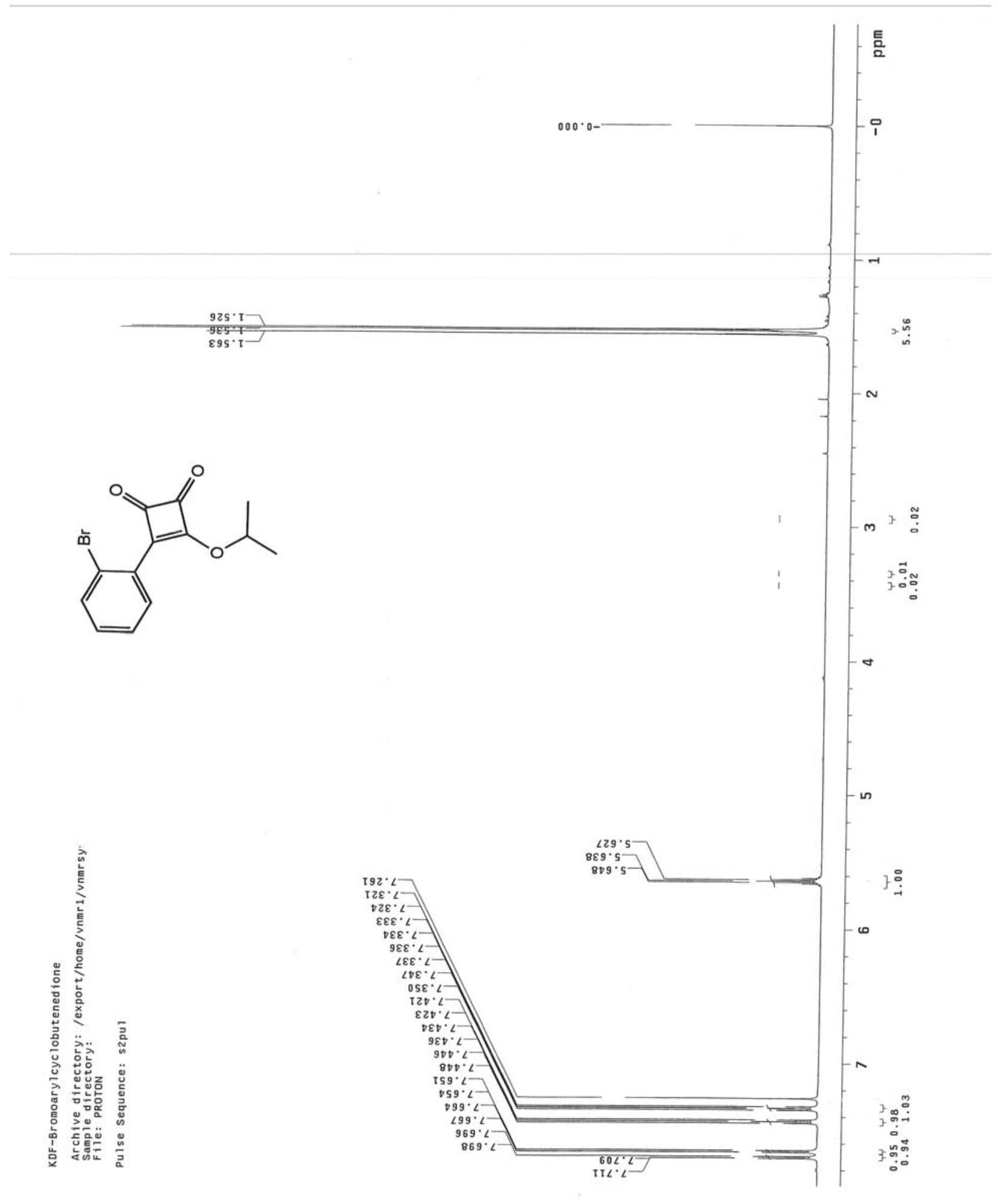

${ }^{1}$ H NMR 3-(2-bromophenyl)-4-isopropoxycyclobut-3-ene-1,2-dione (104) 


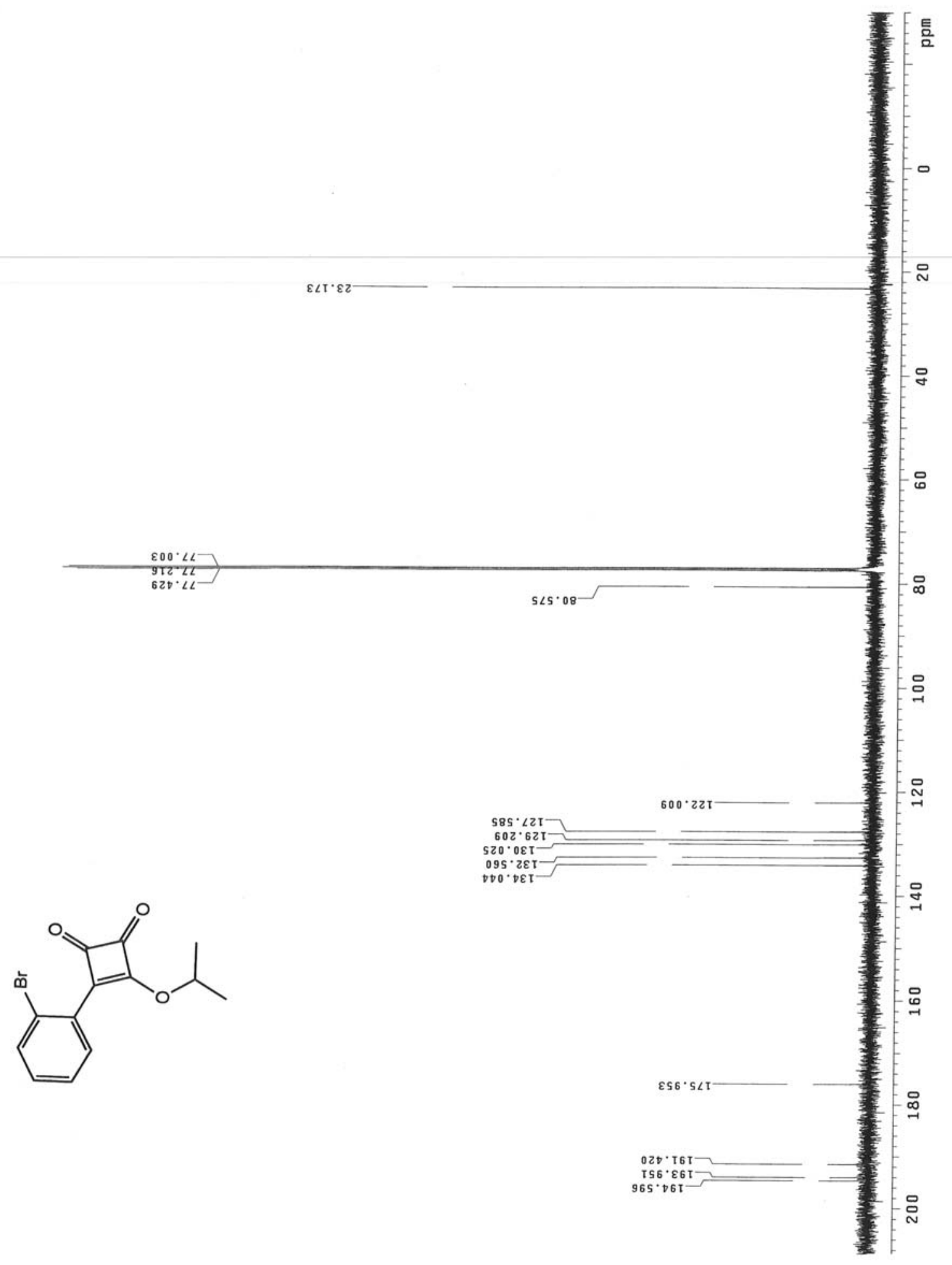

${ }^{13}$ C NMR 3-(2-bromophenyl)-4-isopropoxycyclobut-3-ene-1,2-dione (104) 


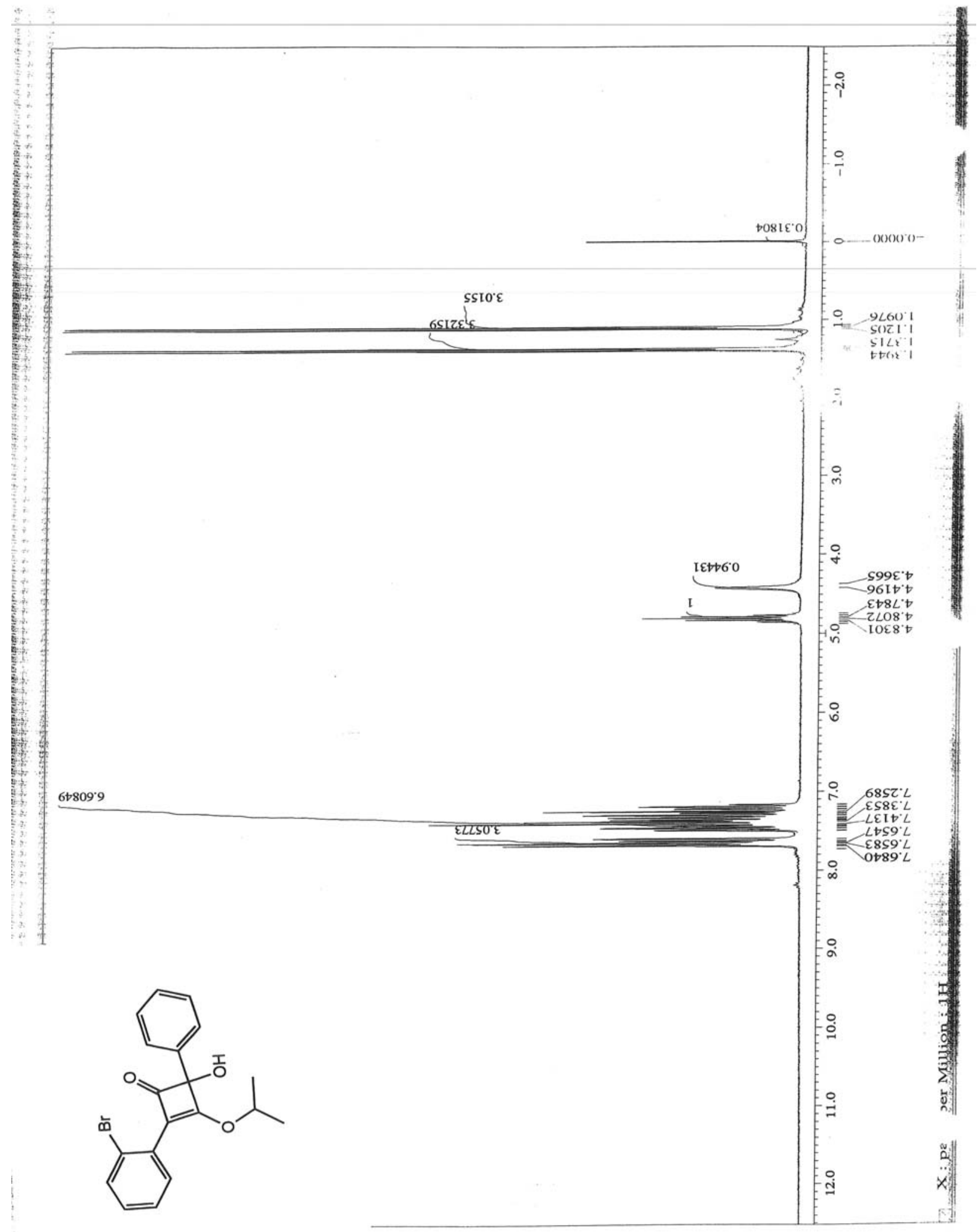

${ }^{1}$ H NMR 2-(2-bromophenyl)-4-hydroxy-3-isopropoxy-4-phenylcyclobut-2-enone (105) 


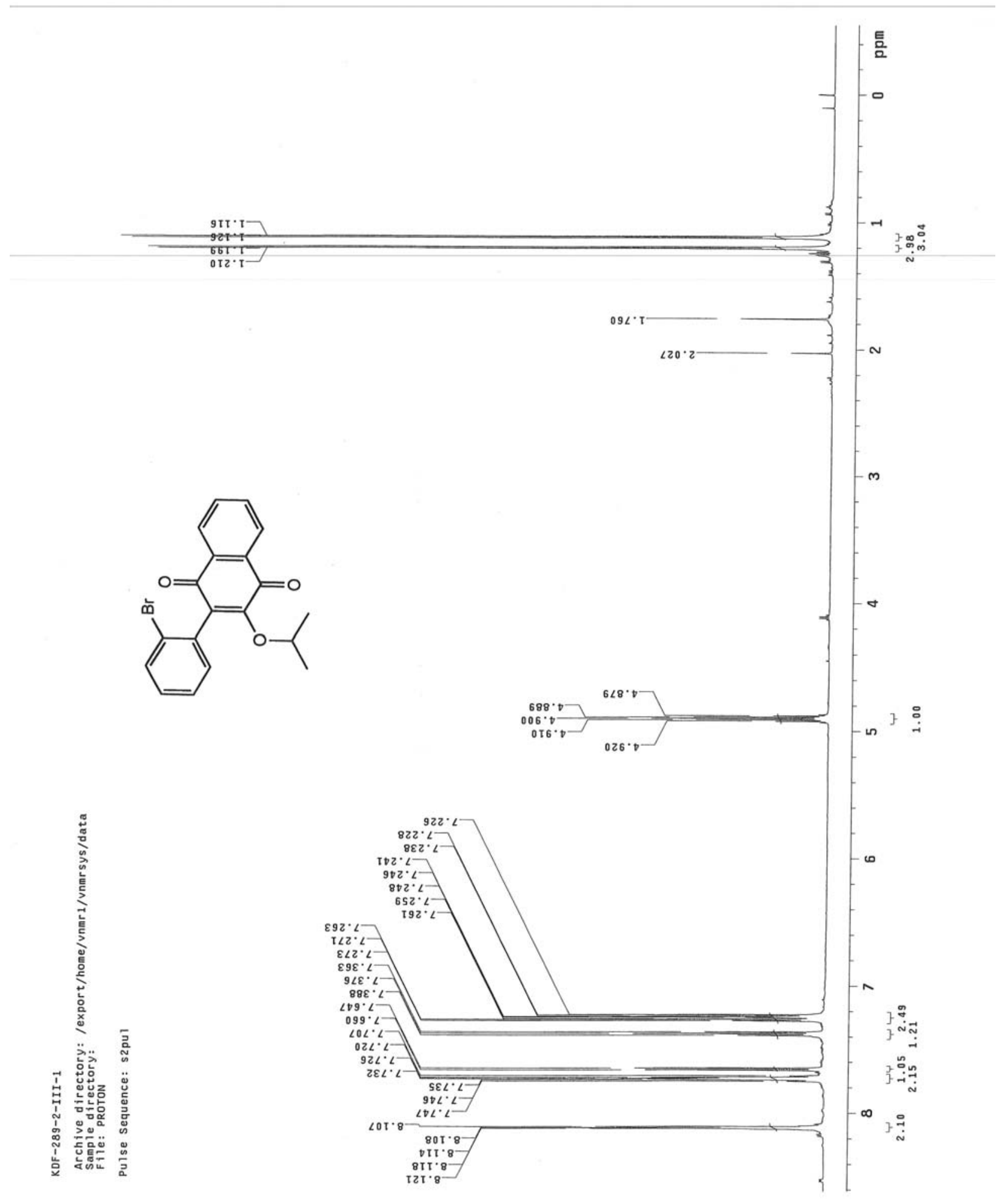

${ }^{1}$ H NMR 2-(2-bromophenyl)-3-isopropoxynaphthalene-1,4-dione (106) 


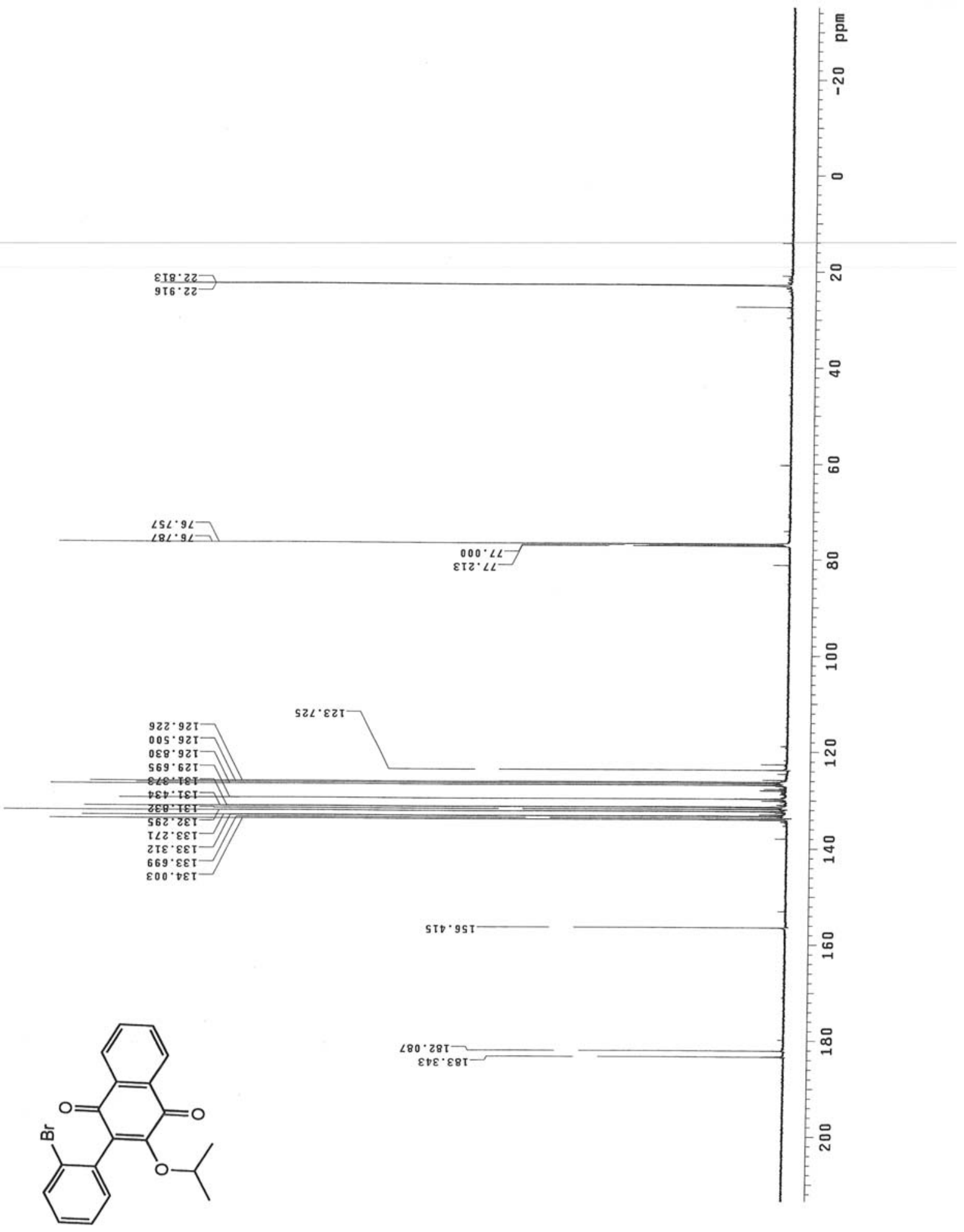

${ }^{13}$ C NMR 2-(2-bromophenyl)-3-isopropoxynaphthalene-1,4-dione (106) 


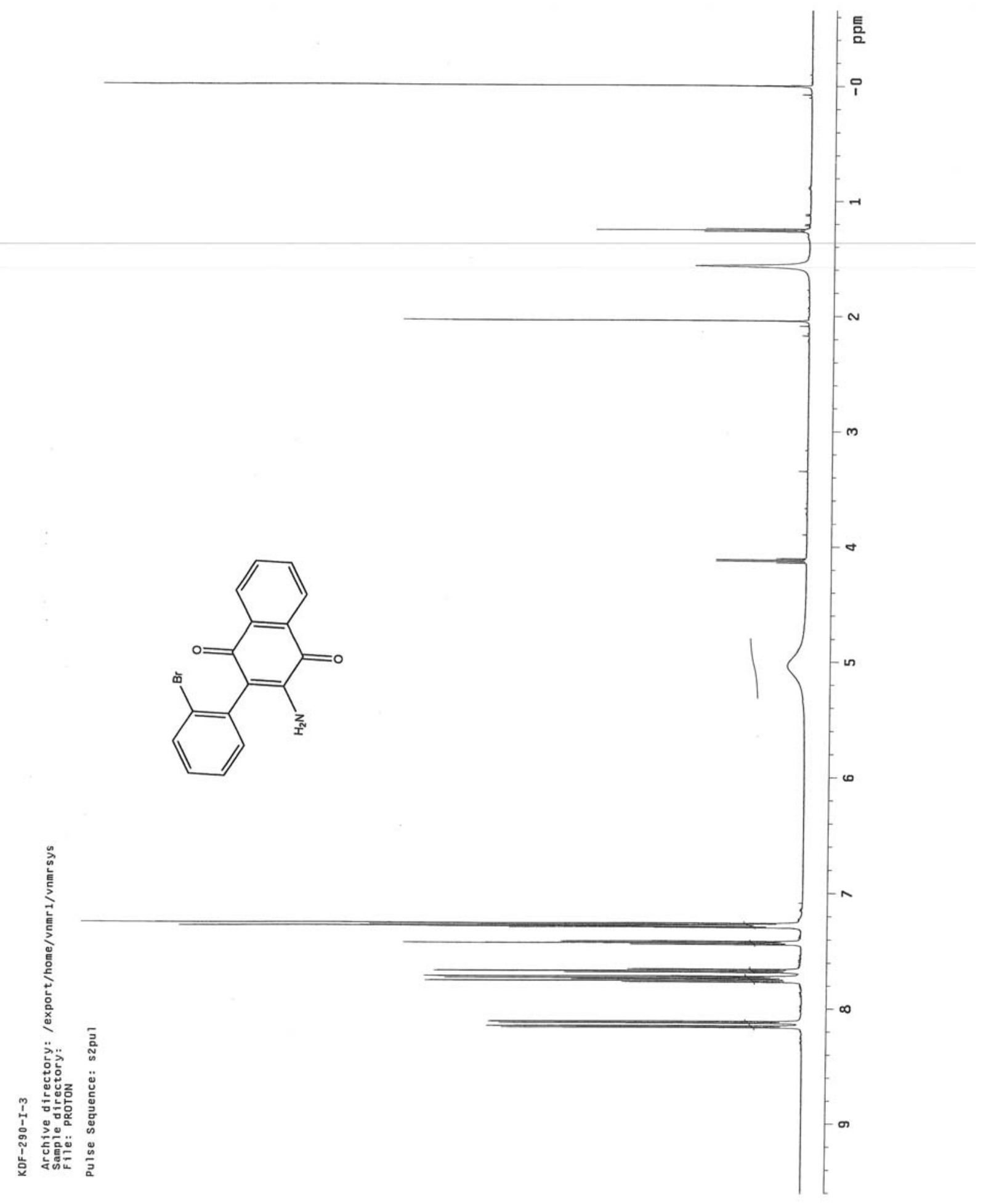

${ }^{1}$ H NMR 2-amino-3-(2-bromophenyl)naphthalene-1,4-dione (109) 


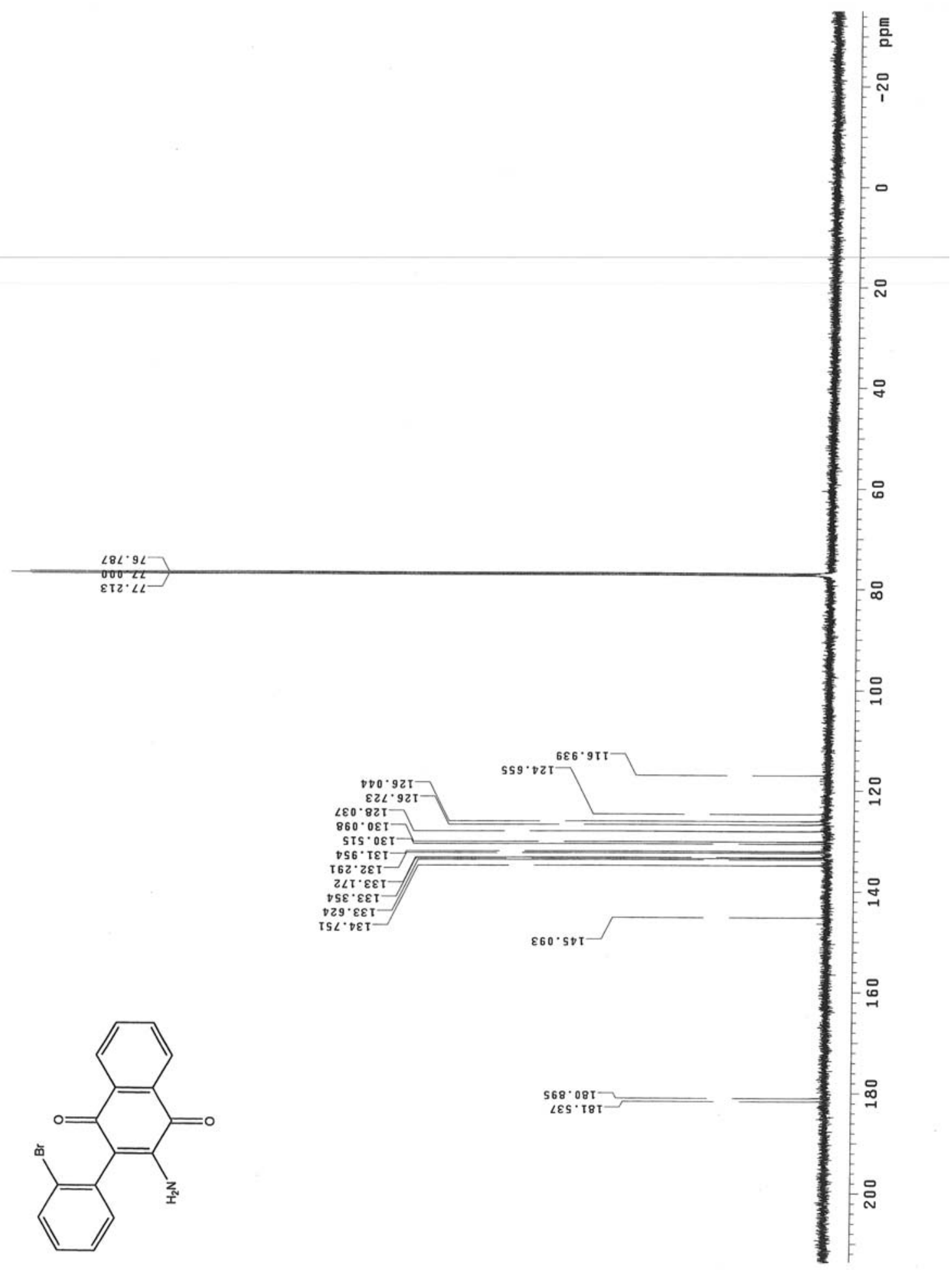

${ }^{13}$ C NMR 2-amino-3-(2-bromophenyl)naphthalene-1,4-dione (109) 


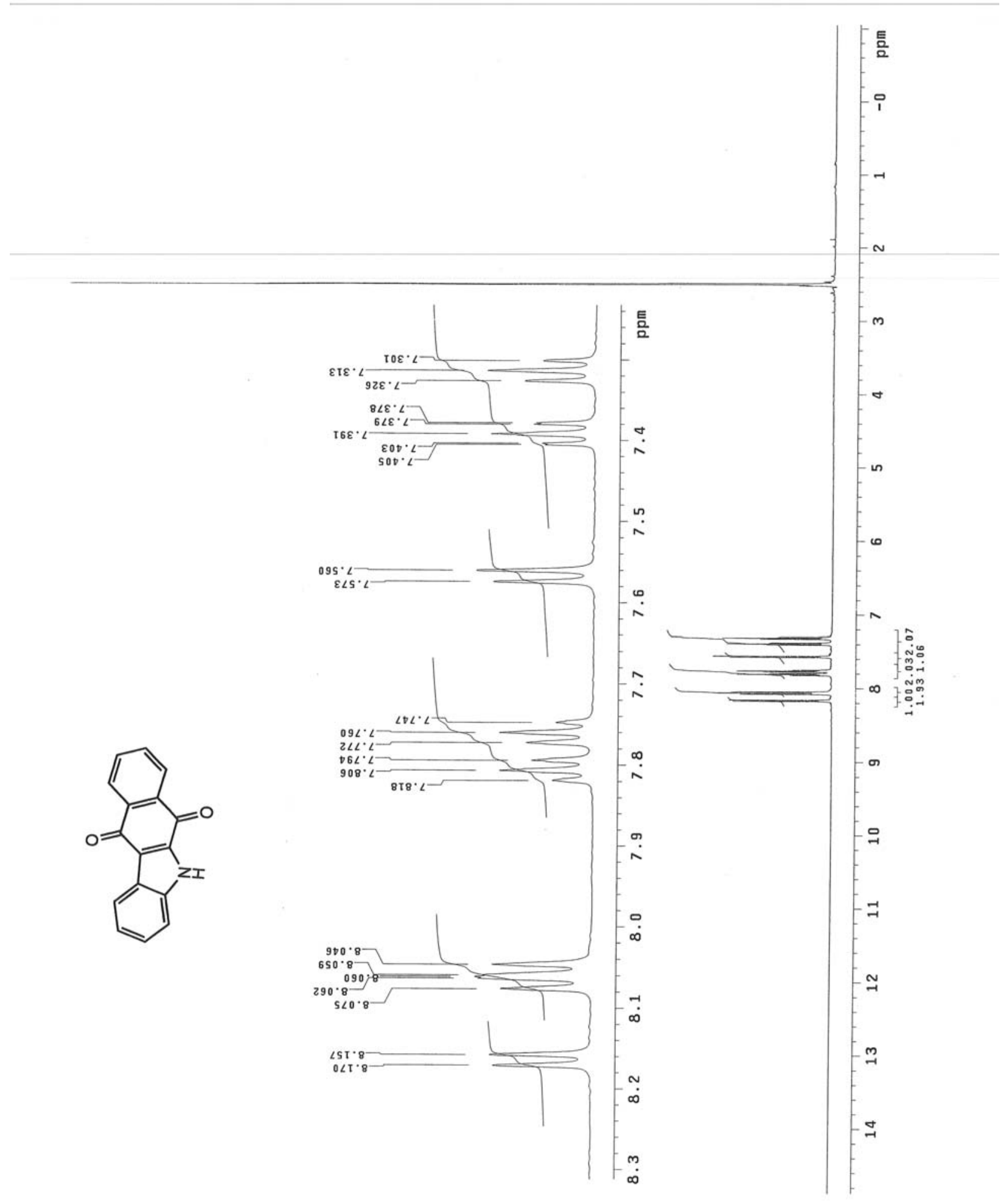

${ }^{1}$ H NMR 5H-benzo[b]carbazole-6,11-dione (110) 


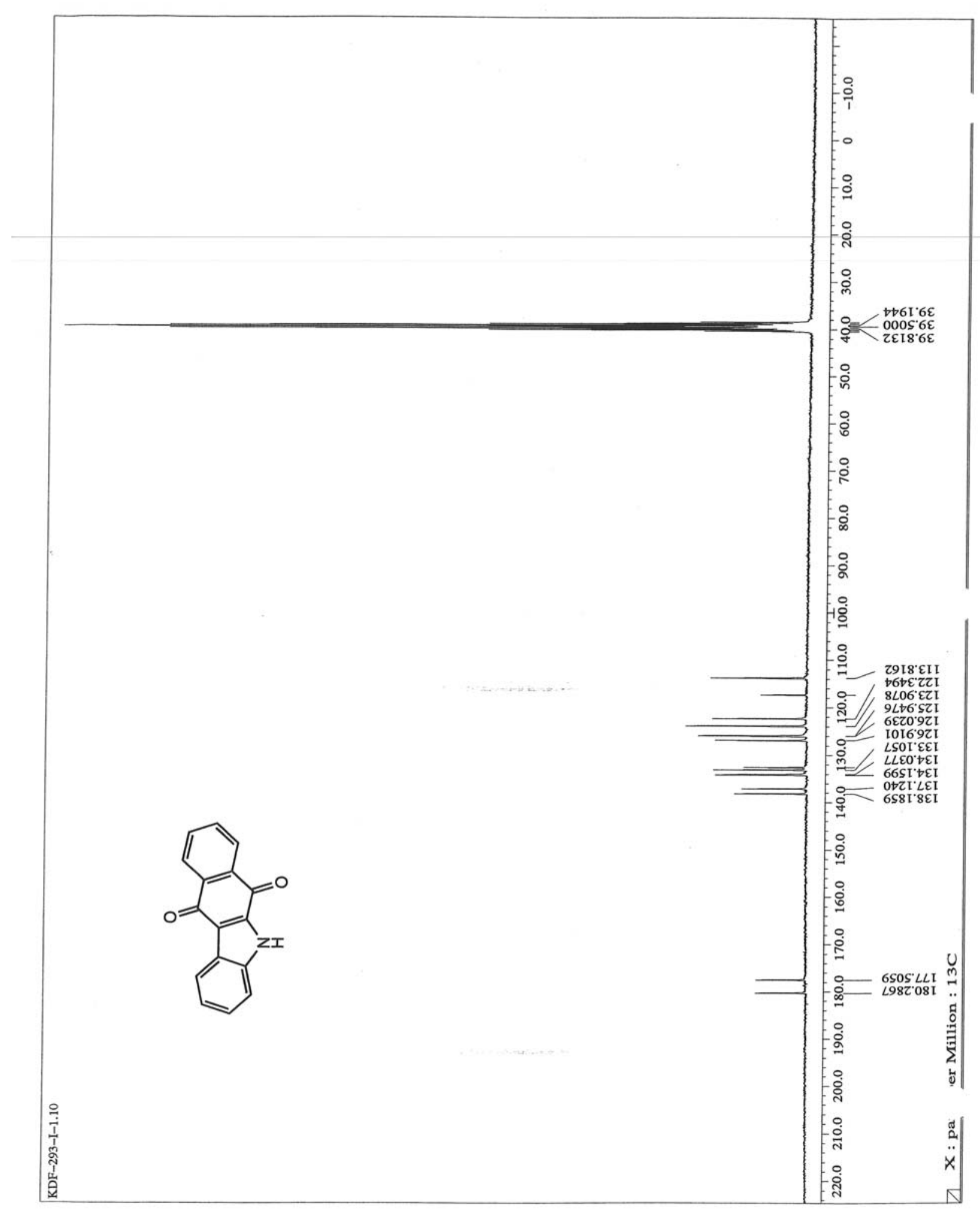

${ }^{13}$ C NMR 5H-benzo[b]carbazole-6,11-dione (110) 


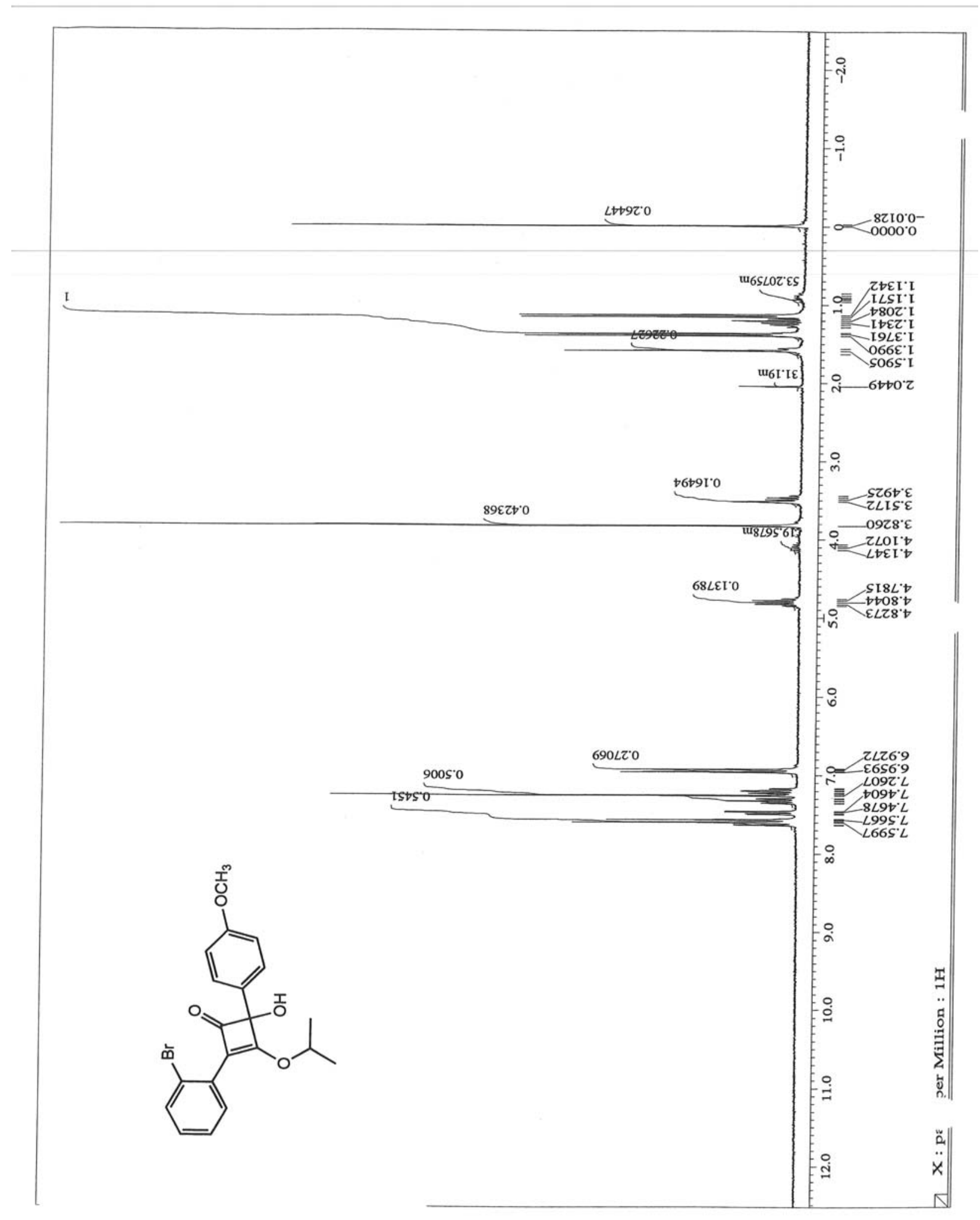

${ }^{1}$ H NMR 2-(2-bromophenyl)-4-hydroxy-3-isopropoxy-4-(4-methoxyphenyl)cyclobut-2-enone (111) 


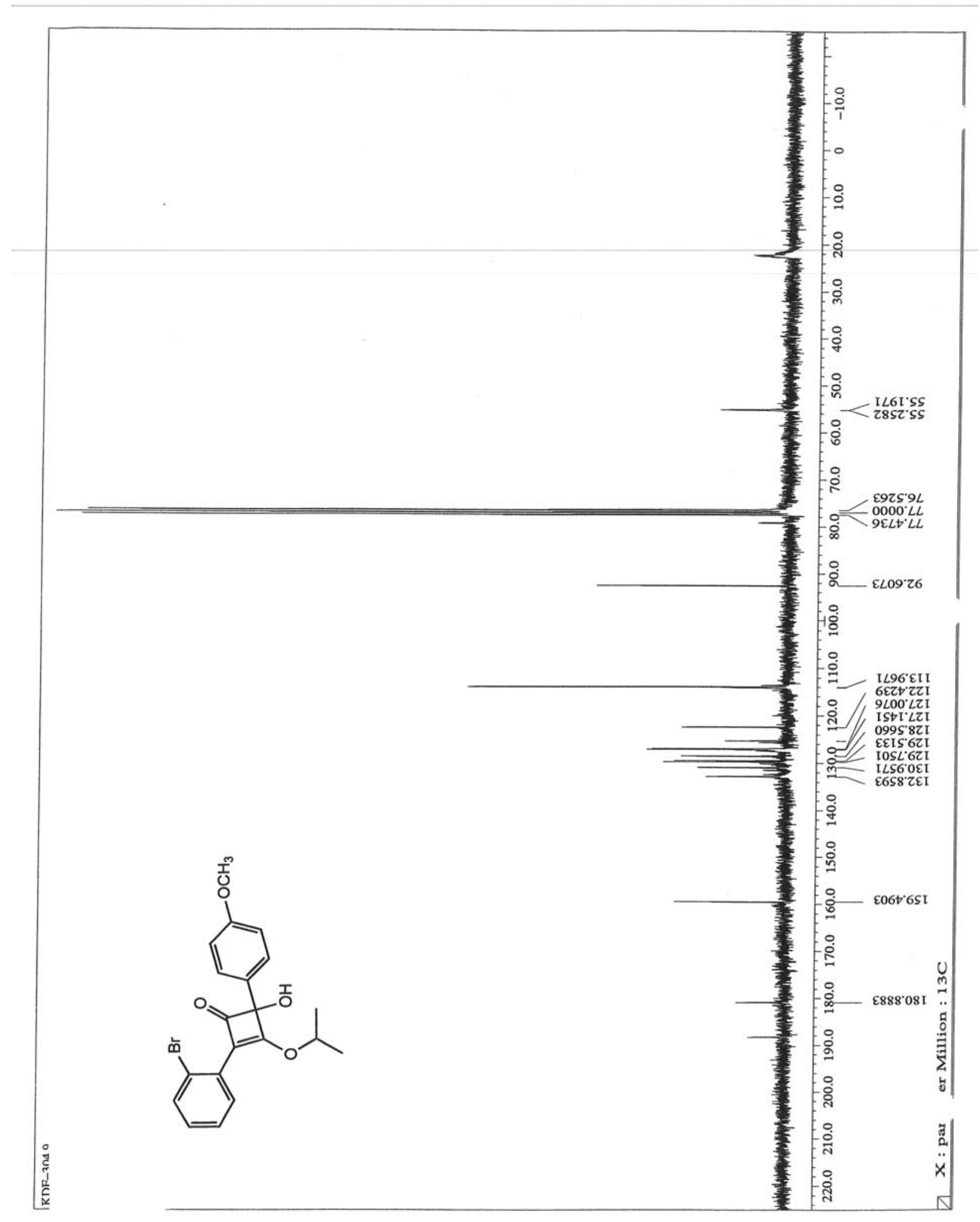

${ }^{13}$ C NMR 2-(2-bromophenyl)-4-hydroxy-3-isopropoxy-4-(4-methoxyphenyl)cyclobut-2-enone (111) 


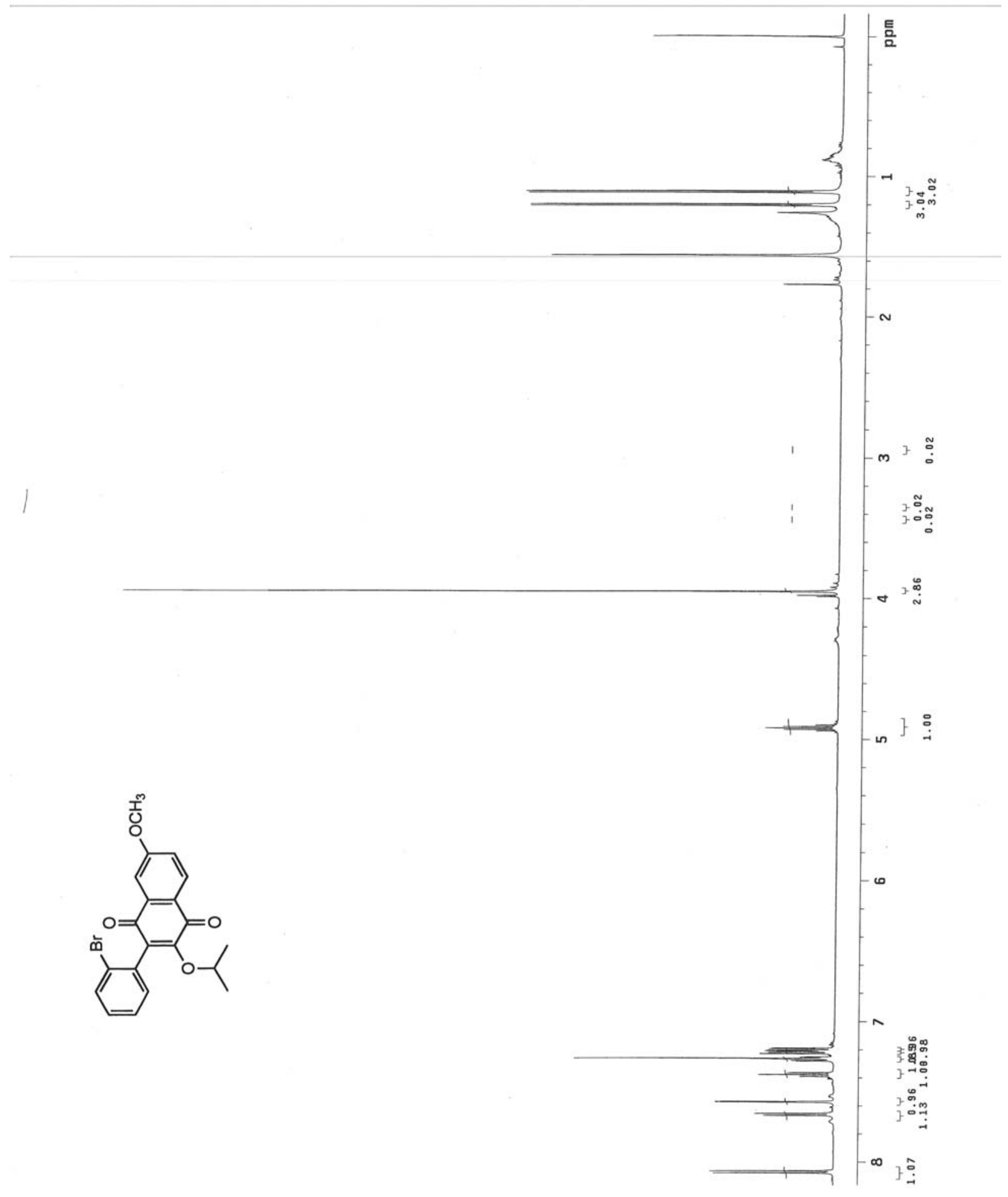

${ }^{1}$ H NMR 3-(2-bromophenyl)-2-isopropoxy-6-methoxynaphthalene-1,4-dione (112) 


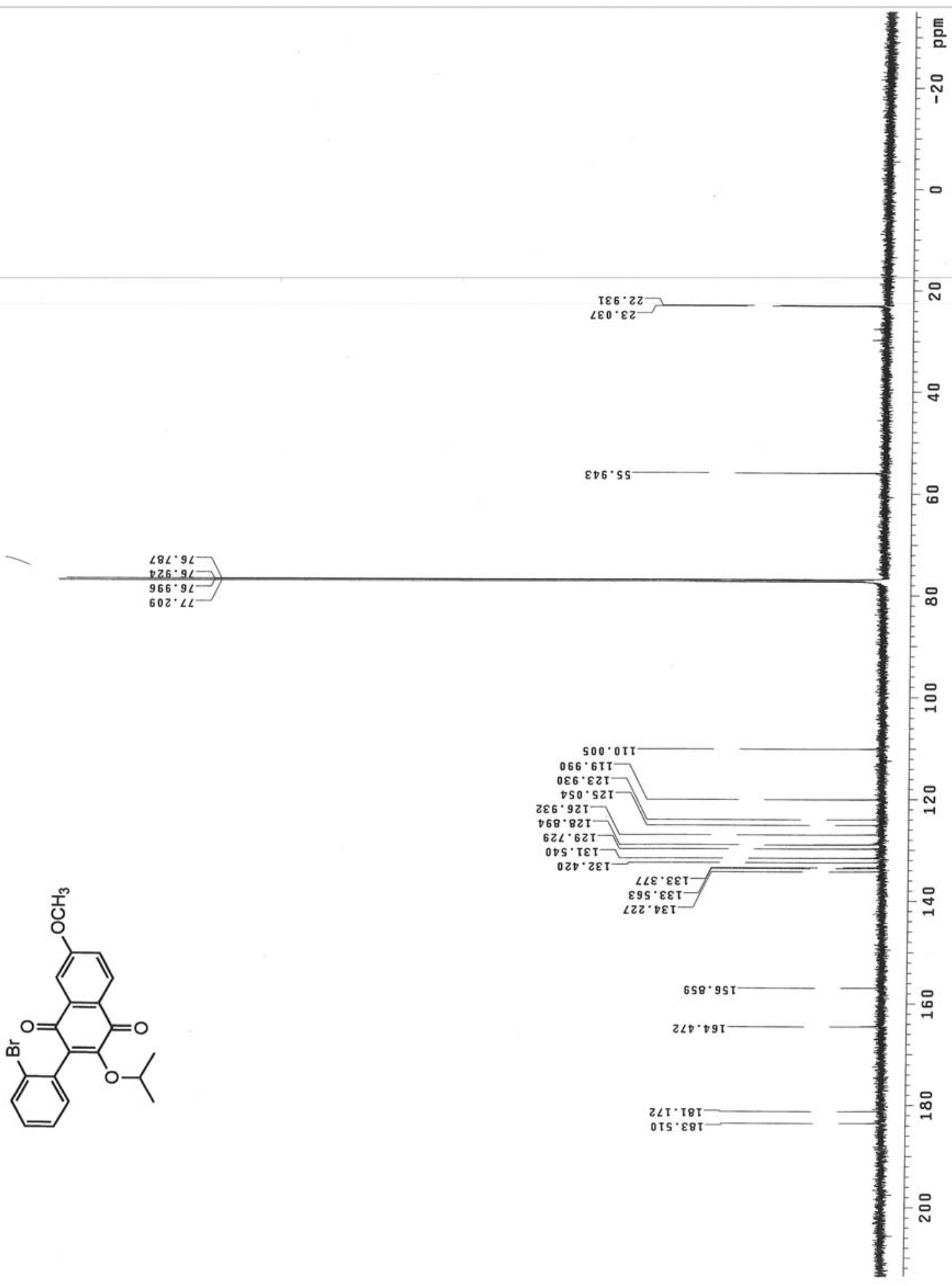

${ }^{13}$ C NMR 3-(2-bromophenyl)-2-isopropoxy-6-methoxynaphthalene-1,4-dione (112) 


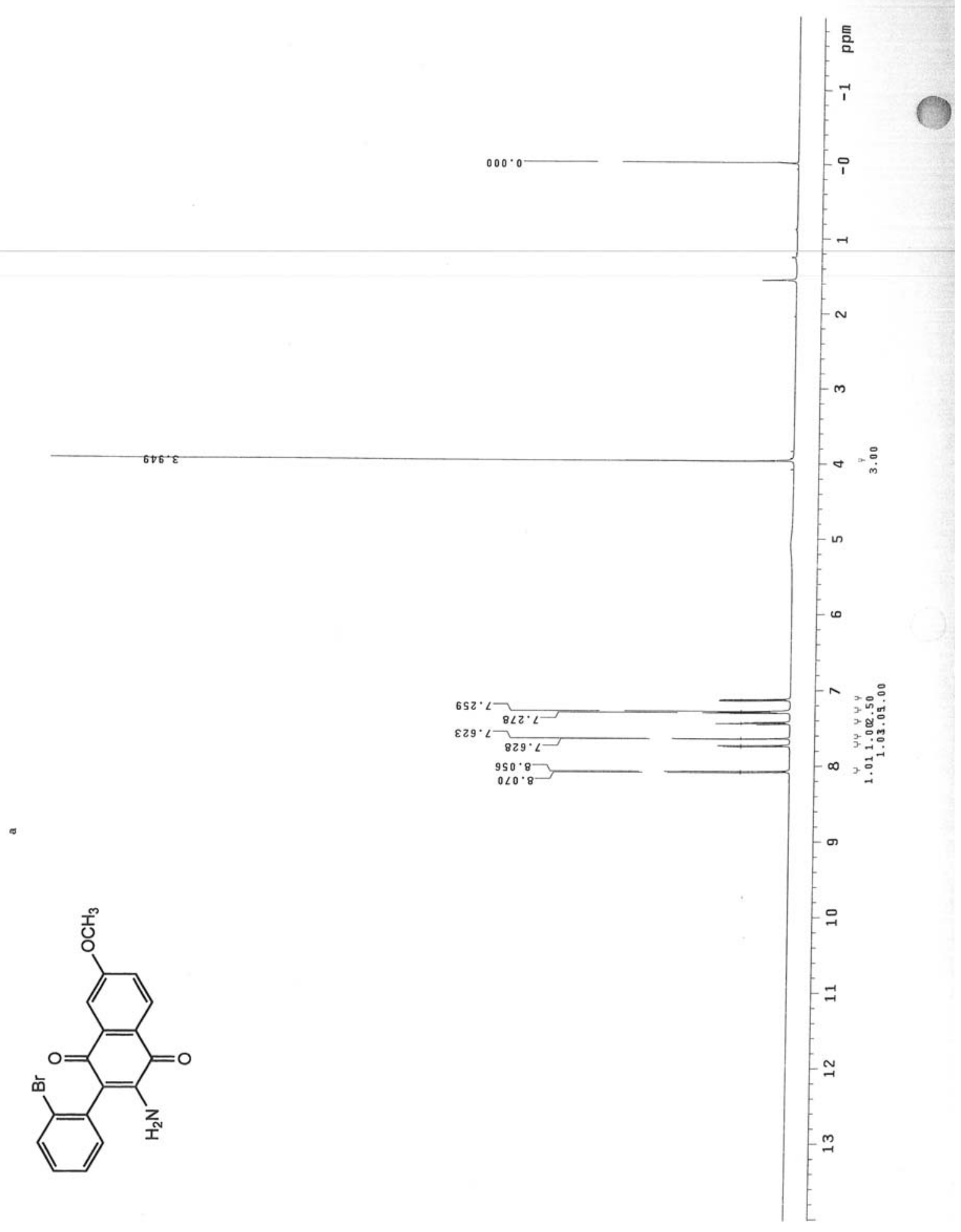

${ }^{1}$ H NMR 2-amino-3-(2-bromophenyl)-6-methoxynaphthalene-1,4-dione (113) 


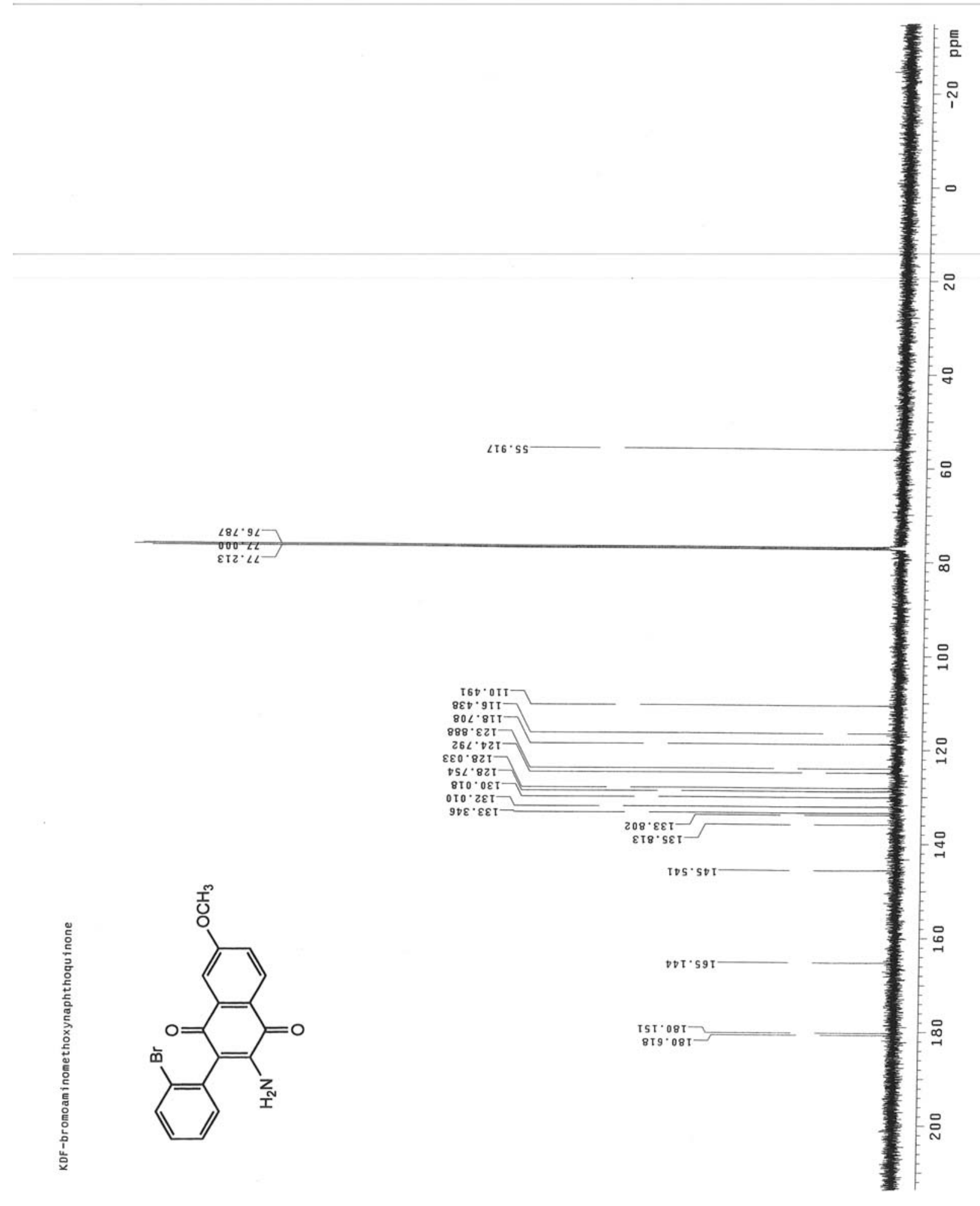

${ }^{13}$ C NMR 2-amino-3-(2-bromophenyl)-6-methoxynaphthalene-1,4-dione (113) 


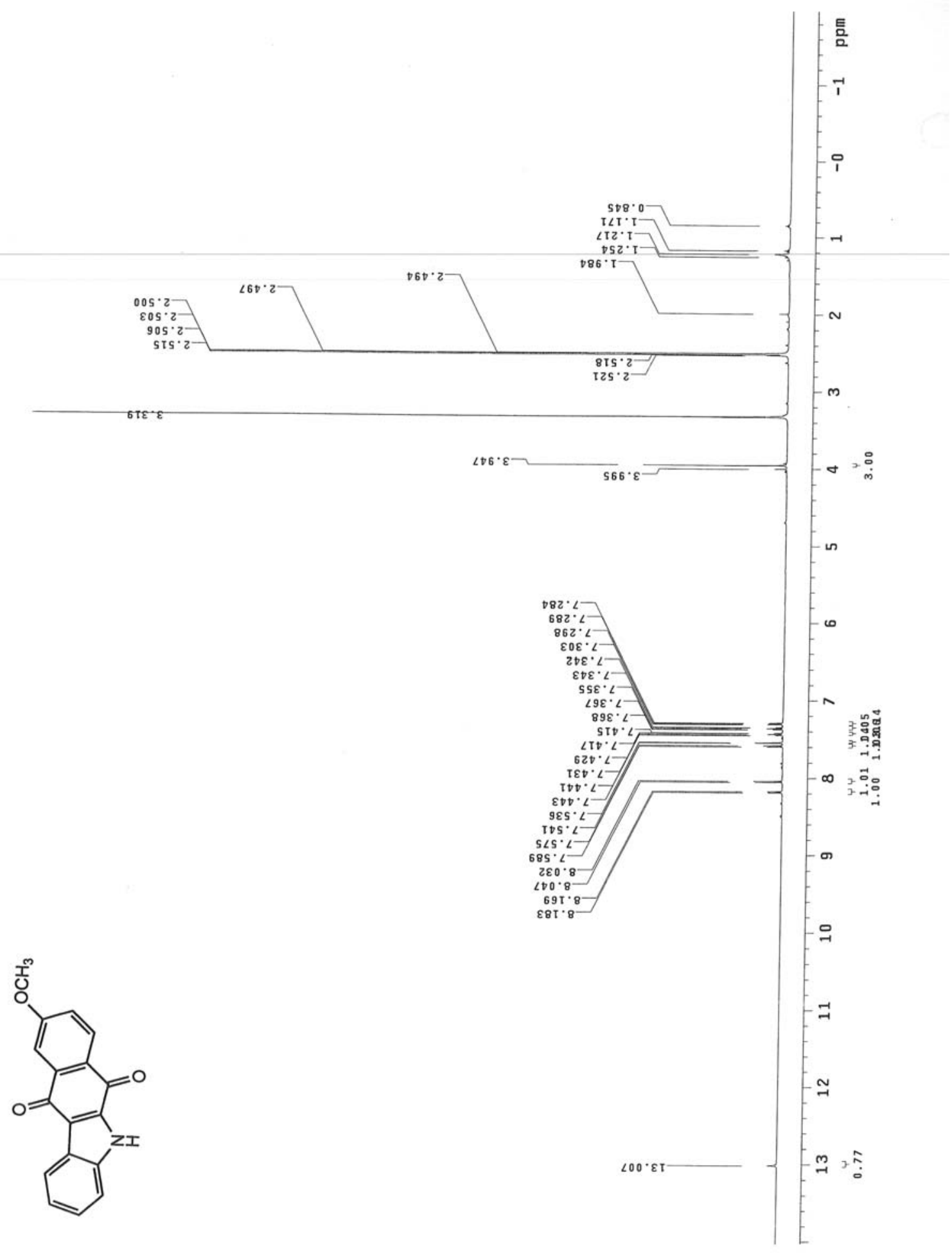

${ }^{1}$ H NMR 9-methoxy-5H-benzo[b]carbazole-6,11-dione (114) 


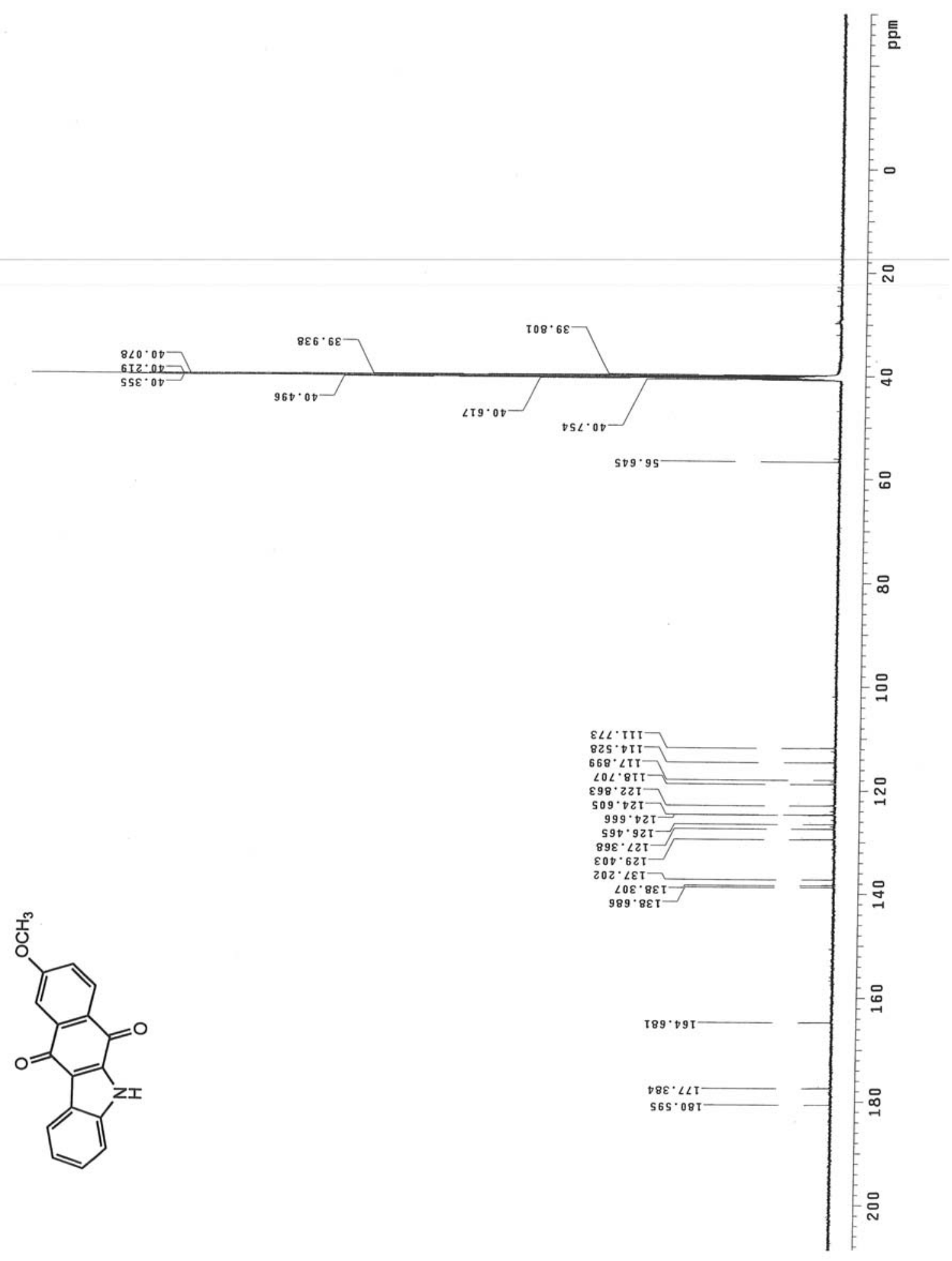

${ }^{13}$ C NMR 9-methoxy-5H-benzo[b]carbazole-6,11-dione (114) 


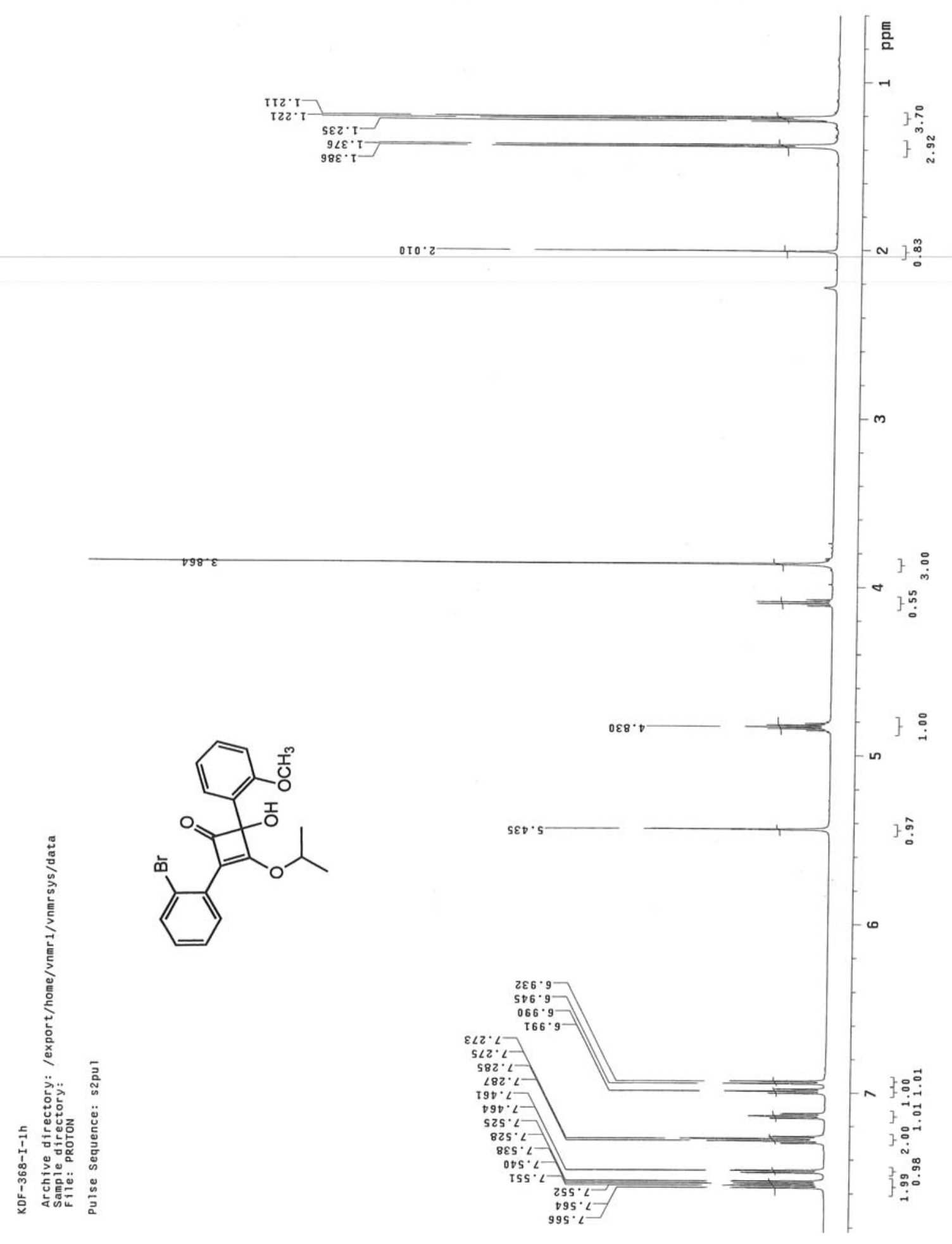

${ }^{1}$ H NMR 2-(2-bromophenyl)-4-hydroxy-3-isopropoxy-4-(2-methoxyphenyl)cyclobut-2-enone (115) 


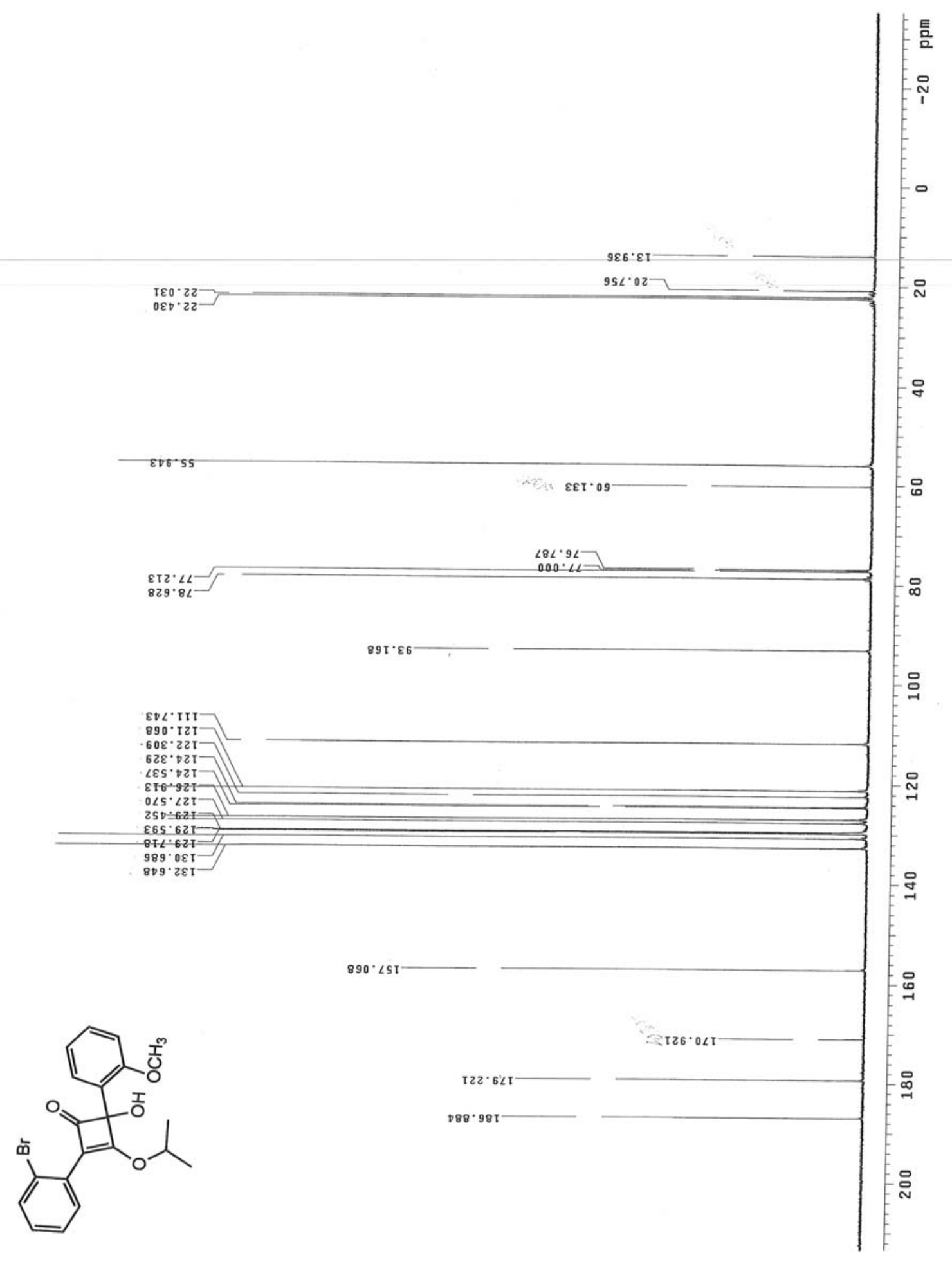

${ }^{13}$ C NMR 2-(2-bromophenyl)-4-hydroxy-3-isopropoxy-4-(2-methoxyphenyl)cyclobut-2-enone (115) 


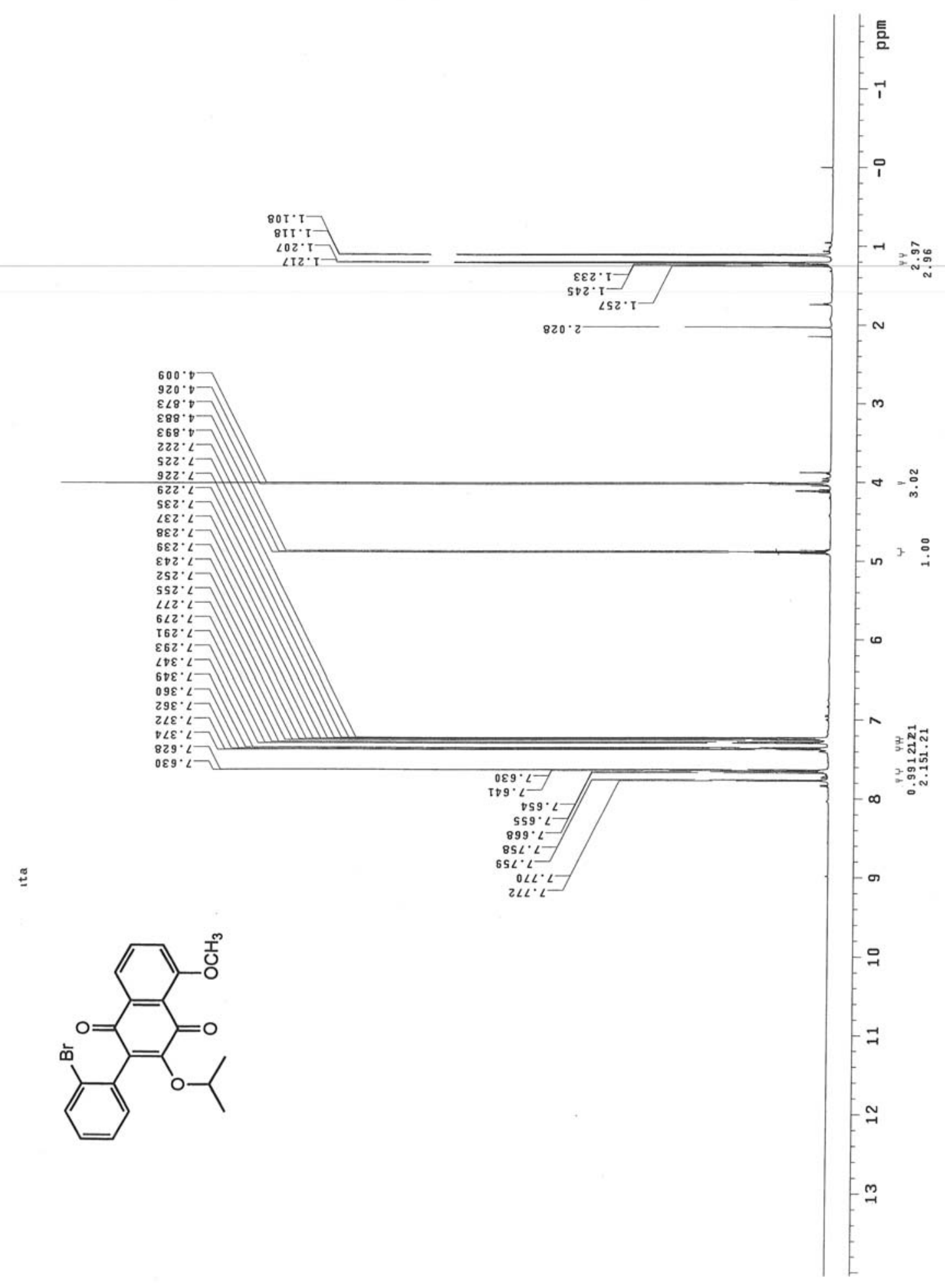

${ }^{1}$ H NMR 2-(2-bromophenyl)-3-isopropoxy-5-methoxynaphthalene-1,4-dione (116) 


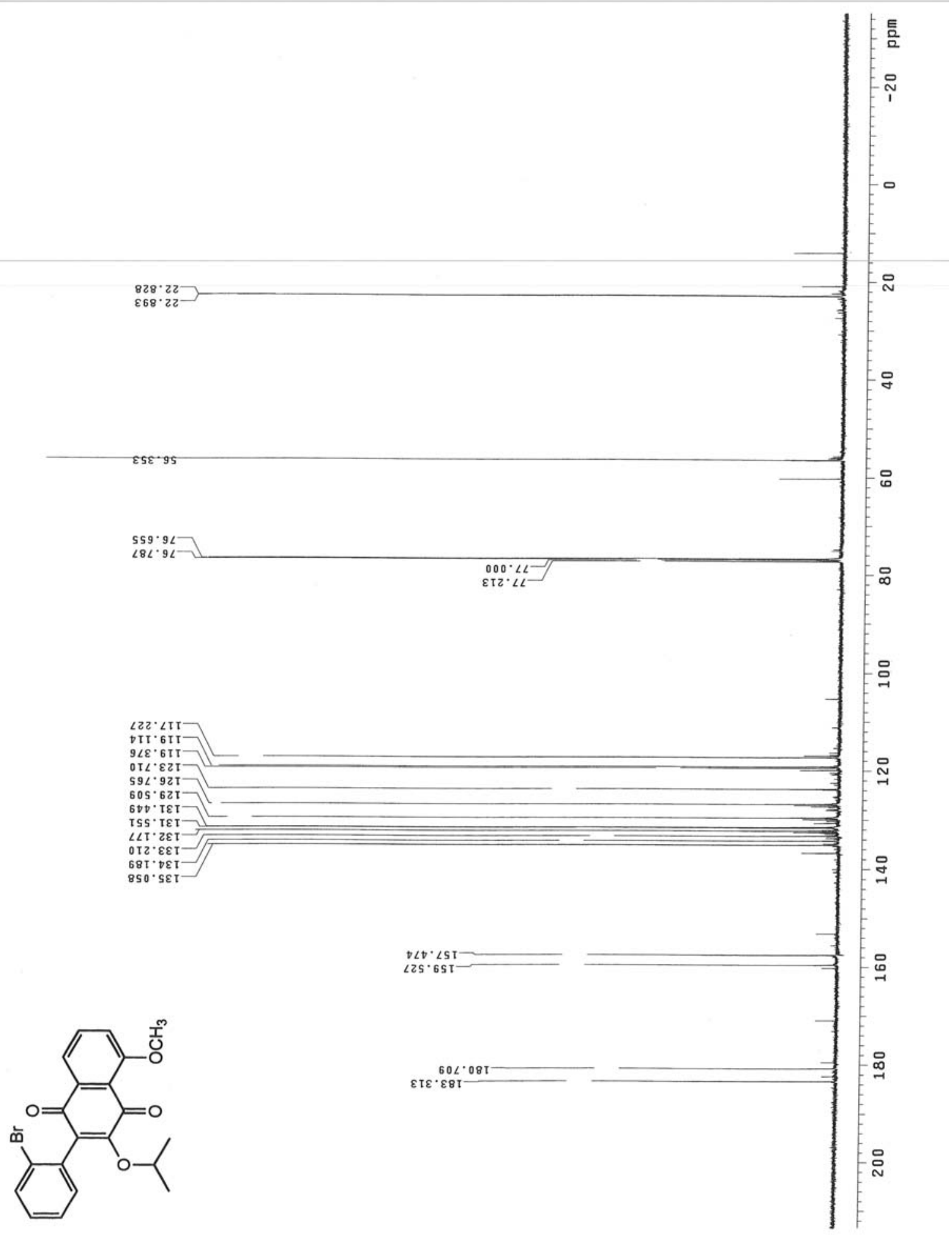

${ }^{13}$ C NMR 2-(2-bromophenyl)-3-isopropoxy-5-methoxynaphthalene-1,4-dione (116) 


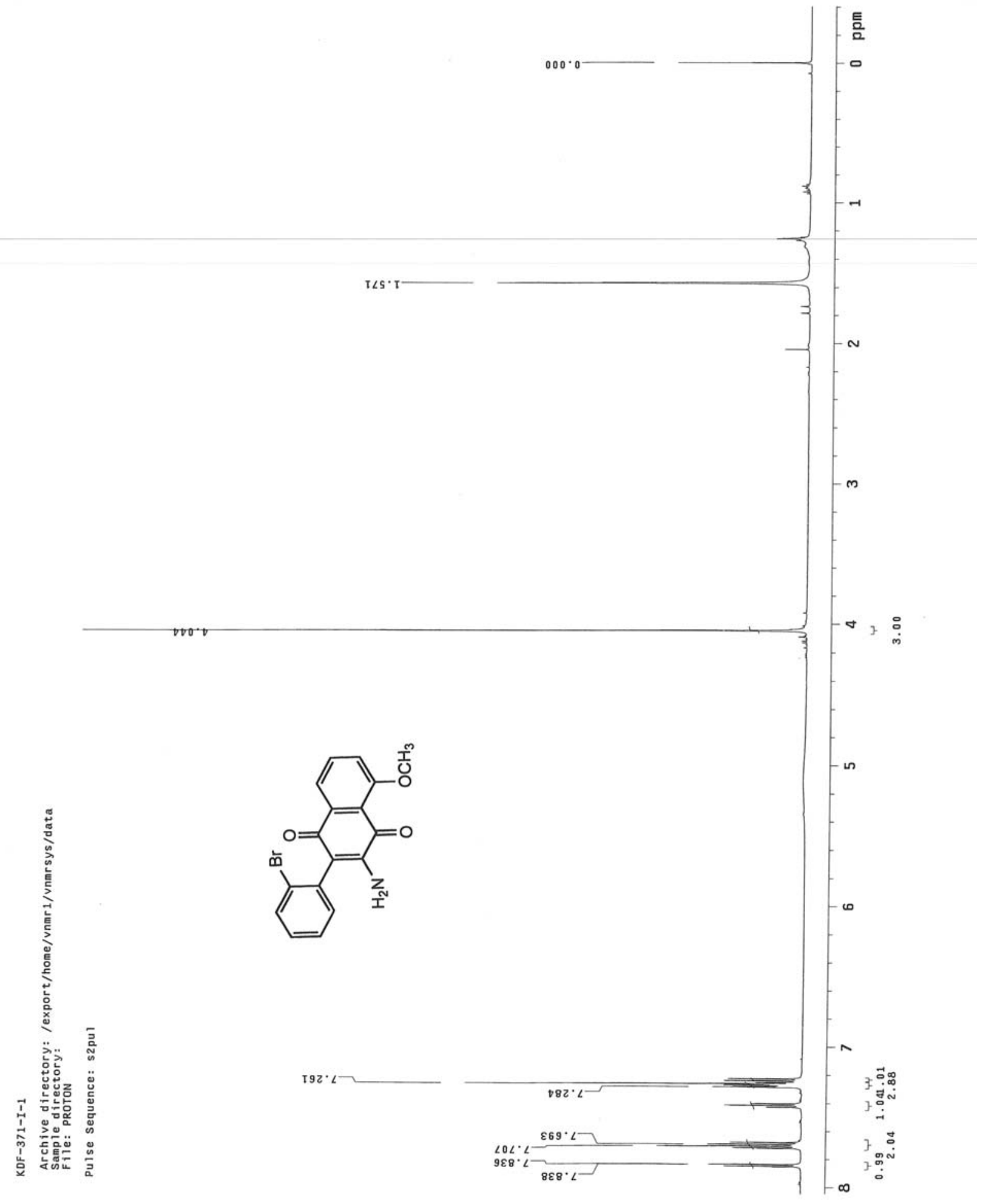

${ }^{1}$ H NMR 3-amino-2-(2-bromophenyl)-5-methoxynaphthalene-1,4-dione (117) 


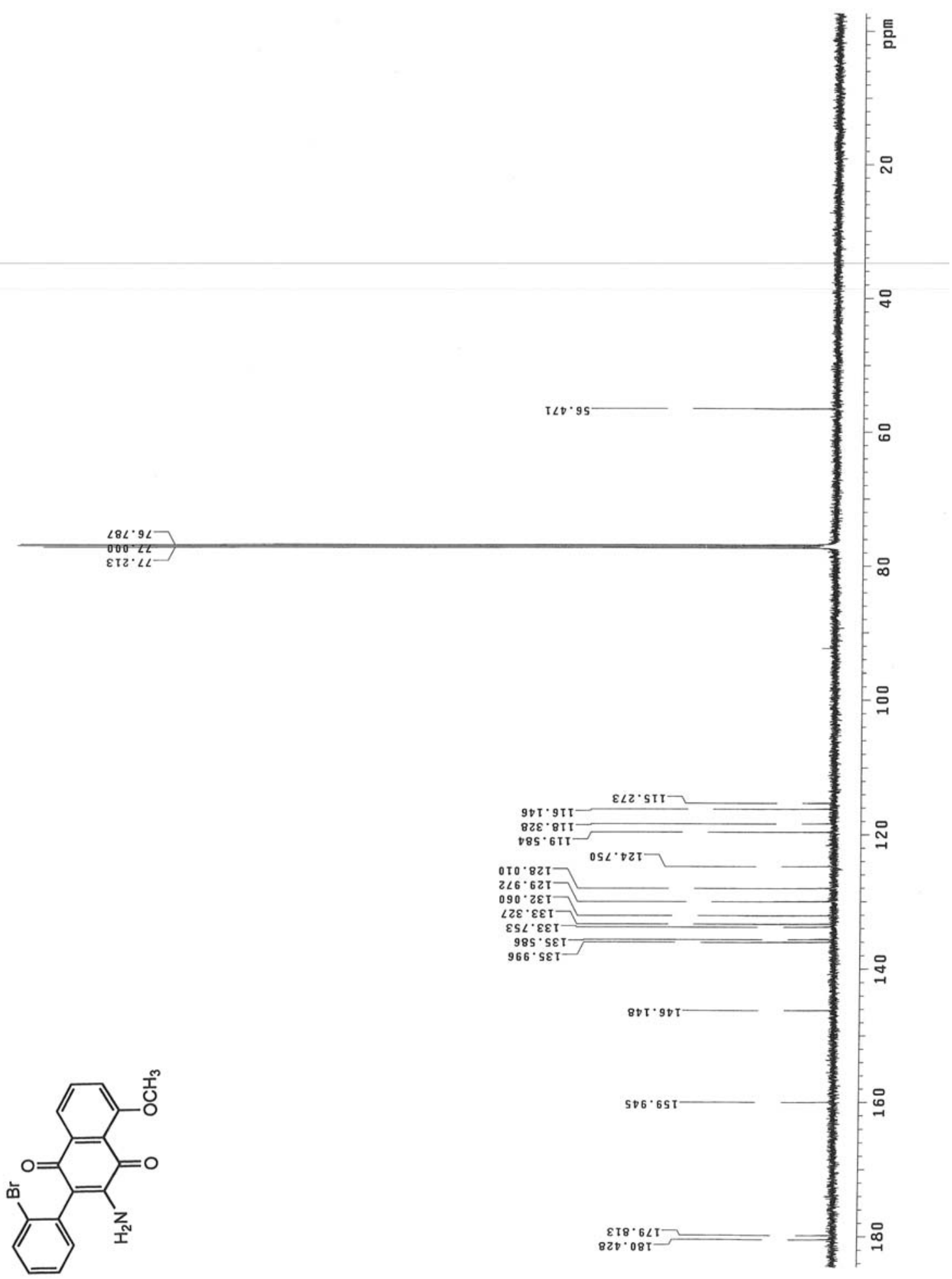

${ }^{13}$ C NMR 3-amino-2-(2-bromophenyl)-5-methoxynaphthalene-1,4-dione (117) 


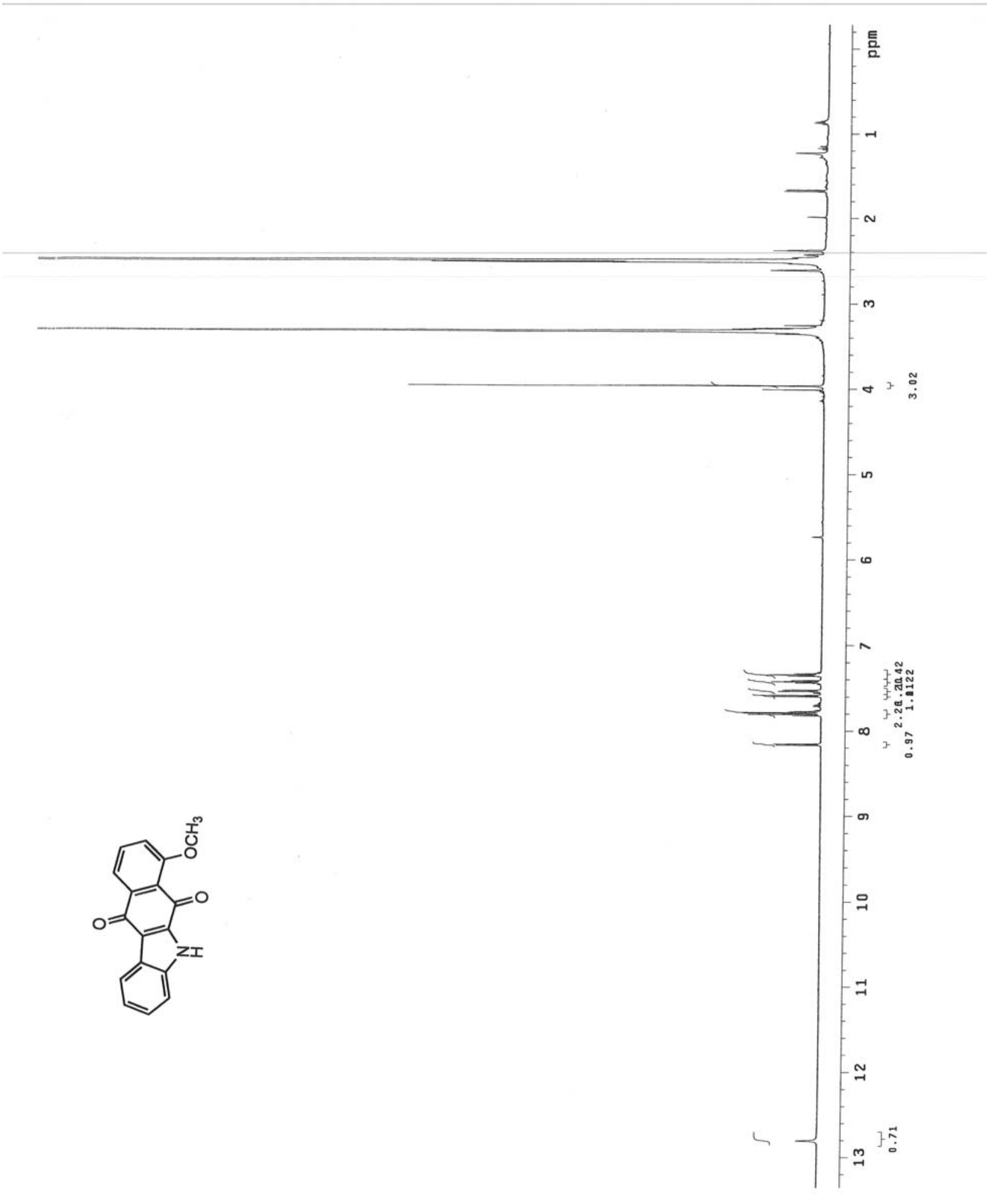

${ }^{1}{ }^{H}$ NMR 7-methoxy-5H-benzo[b]carbazole-6,11-dione (118) 


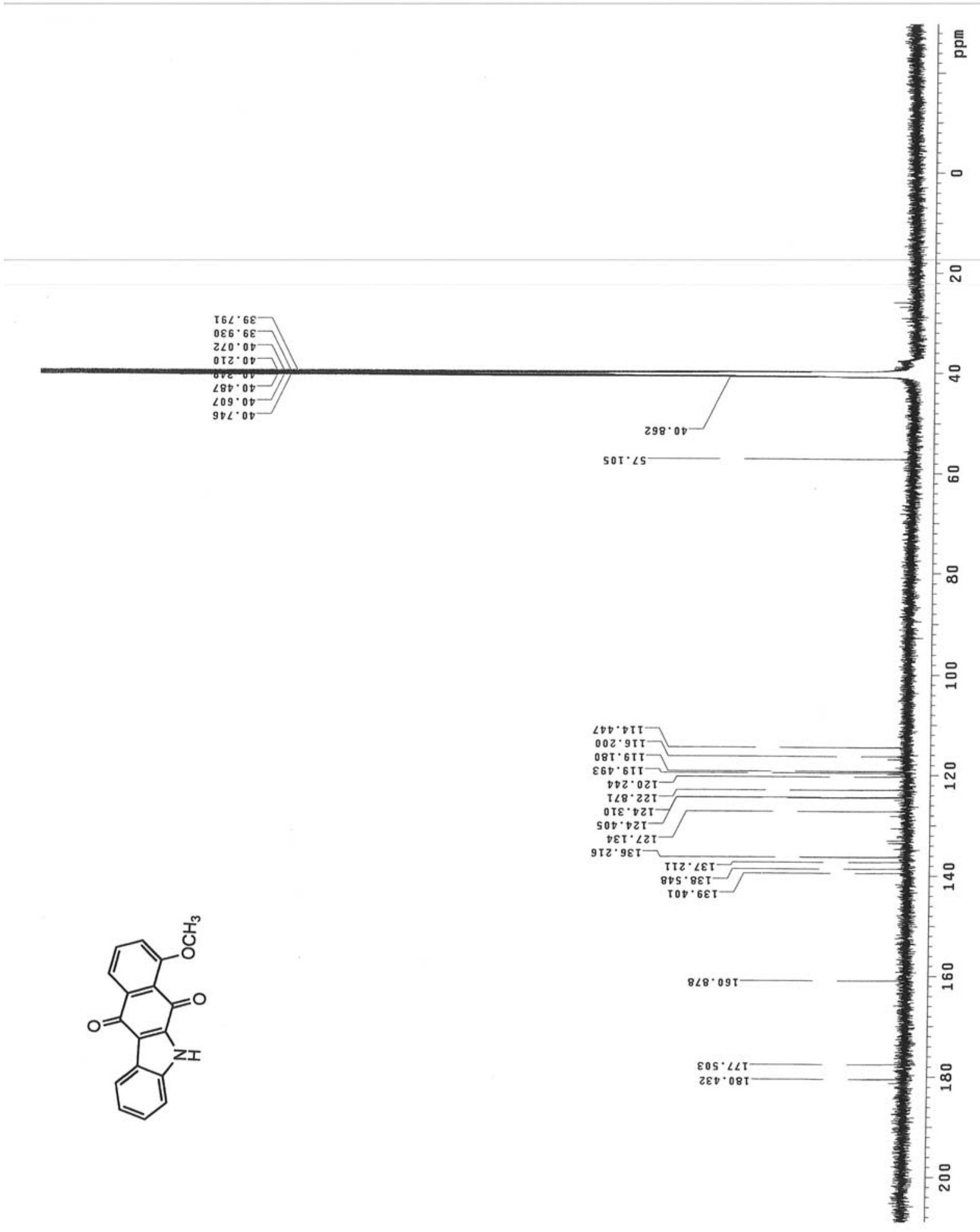

${ }^{13}$ C NMR 7-methoxy-5H-benzo[b]carbazole-6,11-dione (118) 


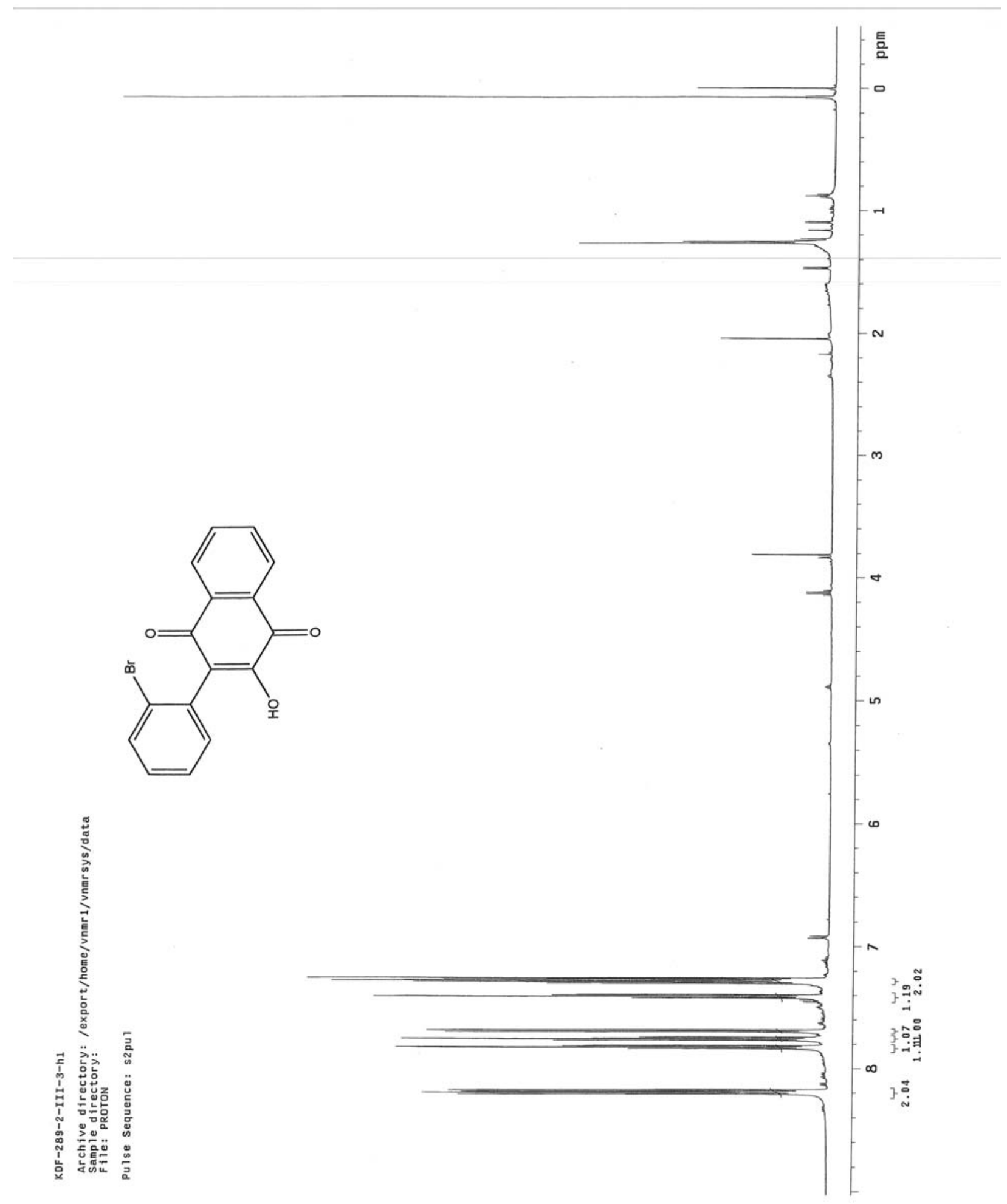

${ }^{1}$ H NMR 2-(2-bromophenyl)-3-hydroxynaphthalene-1,4-dione (119) 


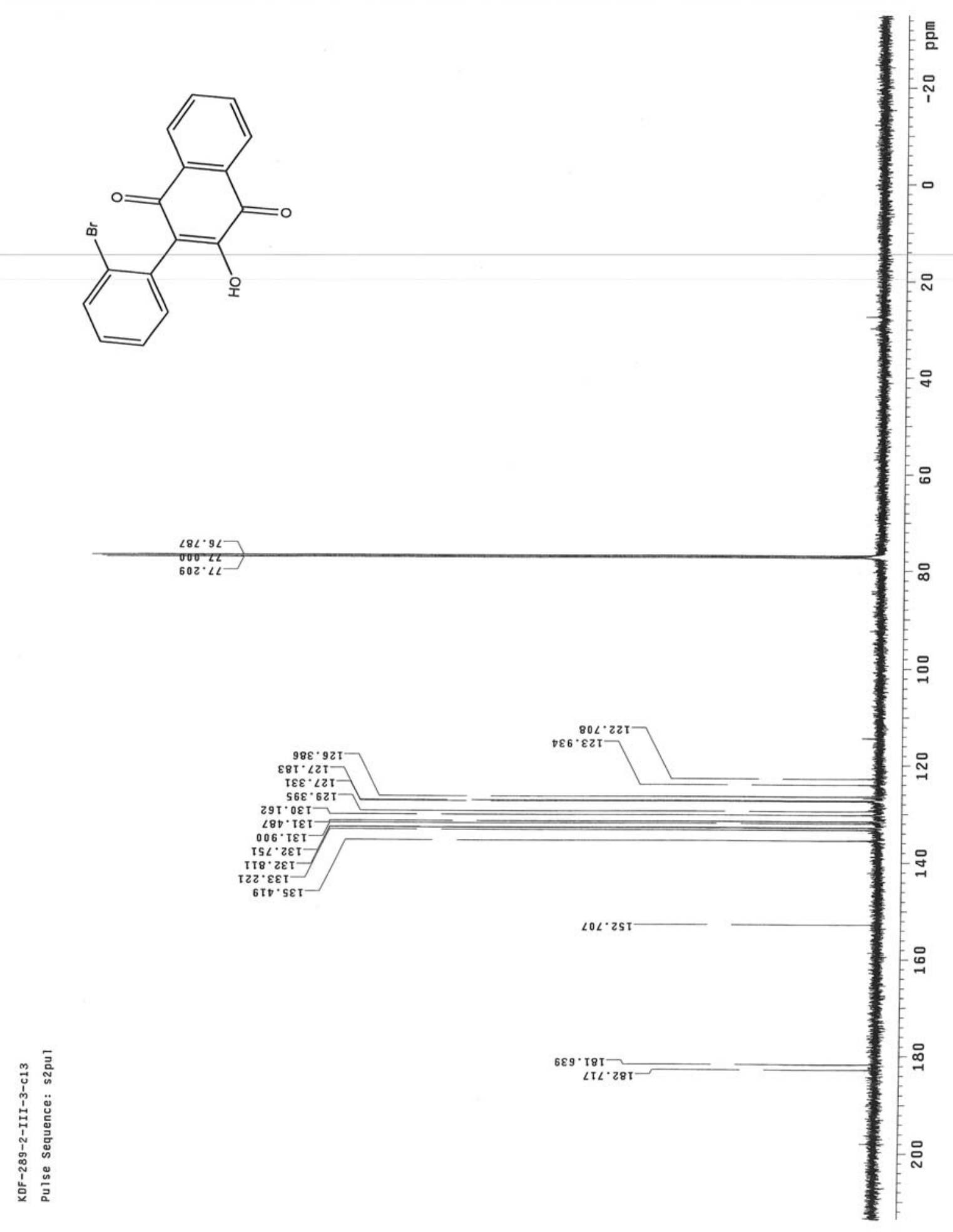

${ }^{13}$ C NMR 2-(2-bromophenyl)-3-hydroxynaphthalene-1,4-dione (119)

Digitally signed by John H. Hagen $\mathrm{DN}$ : $\mathrm{cn}=J$ John $\mathrm{H}$. Hagen, o=West 